\title{
COMPARAÇÃO DE SEIS CULTIVARES DE MILHO SUBMETIDOS A NÍVEIS DE ALUMÍNIO EM SOLUÇÃO NUTRITIVA
}

\author{
MARIA DA CONCEIÇÃO RIVOLI COSTA \\ Enge Agrônomo
}

ORIENTADOR: Prof. Dr. QUIRINO AUGUSTO DE CAMARGO CARMELLO

Dissertação apresentada à Escola Superior de Agricultura "Luiz de Queiróz", da Universidade de São Paulo, para obtenção do Título de Mestre em Agronomia, Área de Concentração: Solos e Nurrição de Plantas .

P I R A C I C A B A

Estado de São Paulo - Brasil

Fevereiro - 1995 
CATALOGACAO NA PUBLICAGAO

DIVISAO DE BIBLIOTECA E DOCUKENTACAO - CAMPUS "LUIZ DE QUEJROZ"/USP

Costa, Maria da Conceiço Rivoli

C837c Conparaçso de seis cultivares de nilho subaetidos a niveis de aluainio en soluç̧o nutritiva. Piracicaba, 1995.

165p. ilus.

Di55. (Hestre) - ESALO

Bibliografia.

1. Aluminio en milho 2. Mitho - Nutriço 1. Escola Superior de Agricultura Luiz de Queiroz, Piracicaba

$\cos 633.15$ 


\title{
COMPARAÇÃO DE SEIS CULTIVARES DE MILHO SUBMETIDOS A NÍVEIS DE ALUMÍNIO EM SOLUÇÃO NUTRITIVA
}

\author{
MARIA DA CONCEIÇÃO RIVOLI COSTA
}

Aprovada em: 12/04/1995

Comissão julgadora:

Prof. Dr. Gil Miguel de Sousa Câmara ESALQ/USP

Prof. Dr. Francisco Antonio Monteiro ESALQ/USP

Prof. Dr. Quirino Augusto de Camargo Carmello ESALQ/USP

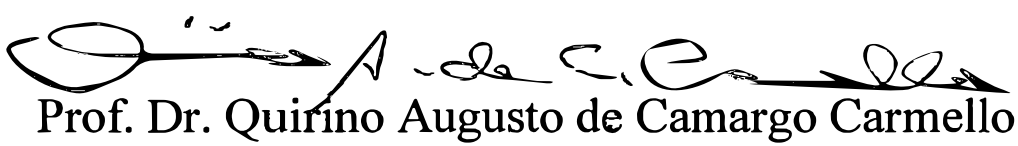
- Orientador - 


\section{"IN MEMORIAN"}

Prof. Dr. HENRIQUE PAULO HAAG, orientador e amigo que, em sua vida exerceu o espírito de doação e incentivo

\section{DEDICO}

A meu esposo ANSELMO, a nossos filhos GABRIELA e RAFAEL e à minha mãe ALICE, 


\section{AGRADECIMENTOS}

Ao Prof. Dr. Quirino Augusto de Camargo Carmello pela orientação, amizade, incentivo, profissionalismo e pela forma precisa e objetiva com que me orientou;

Aos Profs. Drs. Antonio Roque Dechen e Francisco Antonio Monteiro pela amizade, atenção e incentivo que sempre manifestaram;

À Prof . Adriana Mascarette Labinas pela colaboração e tradução dos textos;

À Escola Superior de Agricultura "Luiz de Queiroz" e à Universidade de Taubaté - UNITAU, pela oportunidade proporcionada para a realização do curso de mestrado;

Ao Setor de Nutrição Mineral de Plantas do Departamento de Química e aos seus funcionários pelas condições oferecidas e pelo apoio na realização deste trabalho;

Ao Centro de Energia Nuclear na Agricultura (CENA), na pessoa do Prof. Dr. Francisco José Krug e Iolanda Aparecida Rufini pela colaboração e facilidades oferecidas na realização das análises de alumínio;

Ao Conselho Nacional de Desenvolvimento Científico e Tecnológico pela concessão da bolsa;

À CARGILL Agrícola S.A., na pessoa do Dr. Glauco Pinto Viegas, pelo fornecimento das sementes e custeio das análises;

À Sra. Mirtes Ventura Sesso pela amizade e colaboração durante a condução da fase experimental; 
Ao Sr. Ricardo de Souza Oliveira pela digitação das tabelas e à Sra. Clotilde Maria Batochio pela digitação das referências bibliográficas;

Às Bibliotecárias Eliana Maria Garcia Sabino e Kátia Maria de Andrade Ferraz pela ajuda na elaboração das referências bibliográficas;

A todos que de alguma forma contribuíram para a realização deste trabalho. 


\section{SUMÁRIO}

\section{Página}

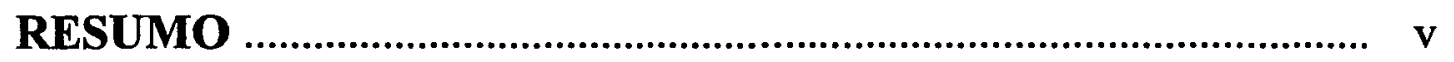

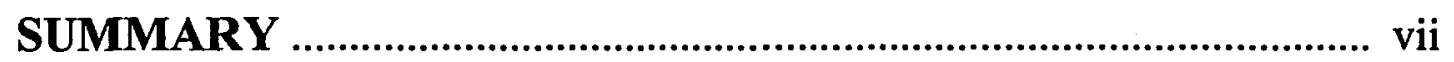

1. INTRODUÇÃO ............................................................... 1

2. REVISÃO DE LITERATURA ….................................... 3

2.1. Alumínio no substrato e sua correção............................. 3

2.2. Alumínio na planta ......................................................... 11

2.3. Efeito do alumínio sobre o metabolismo dos nutrientes

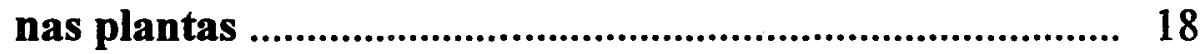

2.3.1. Nitrogênio ............................................................. 20

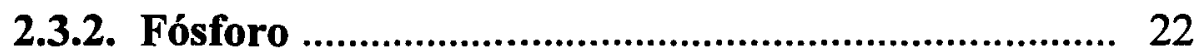

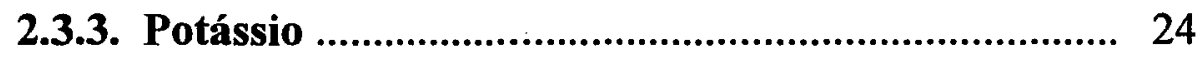

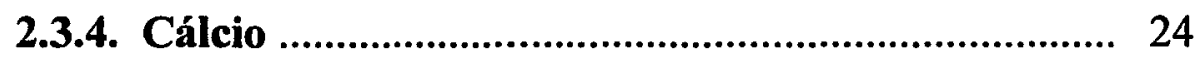

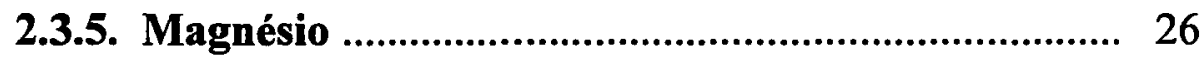

2.4. Efeito do alumínio no milho .............................................. 27

3. MATERIAL E MÉTODOS ................................................... 38

3.1. Local e cultivares............................................................ 38

3.2. Características dos Cultivares............................................ 38

3.3. Fase Experimental........................................................ 39

3.4. Colheita e Avaliação........................................................... 40 
3.5. Delineamento experimental e análise estátistica................ 40

4. RESULTADOS E DISCUSSÃO …....................................... 42

4.1. Peso do material seco............................................................. 42

4.2. Extração de nitrogênio........................................................ 56

4.3. Extração de fósforo................................................................ 70

4.4. Extração de potásio............................................................... 83

4.5. Extração de cálcio................................................................... 98

4.6. Extração de magnésio......................................................... 111

4.7. Extração de alumínio...................................................... 121

4.8. Aspécto das plantas e das raízes........................................ 133

4.9. Discussão geral................................................................... 137

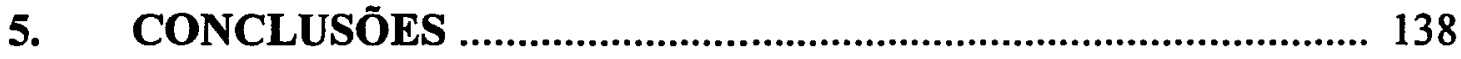

6. REFERÊNCIAS BIBLIOGRÁFICAS _..................................... 139 


\title{
COMPARAÇÃO DE SEIS CULTIVARES DE MILHO SUBMETIDOS A NÍVEIS DE ALUMÍNIO EM SOLUÇÃO NUTRITIVA
}

\author{
Autora: MARIA DA CONCEIÇÃO RIVOLI COSTA
}

Orientador: Prof.Dr. QUIRINO AUGUSTO DE CAMARGO CARMELLO

\section{RESUMO}

Com o objetivo de avaliar o comportamento de seis cultivares de milho (C125, C135, C425, C525, C701 e C805), quando submetidos à seis níveis de alumínio $\left(0,10,20,30,40\right.$ e $\left.50 \mathrm{mg} . \mathrm{L}^{-1}\right)$ em solução nutritiva, com a finalidade de selecionar os cultivares mais tolerantes, foi conduzido um experimento em casa-de-vegetação, em Piracicaba, SP.

Sete dias após a emergência em bandejas contendo areia lavada, as plantas foram transplantadas para caixas de polietileno leitoso com capacidade para $25 \mathrm{~L}$ de solução. As plantas foram sustentadas sobre a solução por placas de isopor contendo 12 furos. Em cada placa foram colocadas as quatro repetições de três dos seis cultivares. Durante o dia as plantas permaneciam nas soluções que continham alumínio e à noite eram transportadas para outras caixas contendo 
solução sem alumínio, sendo as soluções continuamente arejadas. Após cerca de 30 dias, as plantas foram colhidas, separadas em três partes: folhas, colmos e raízes, que foram secas, pesadas e analisadas para os teores de macronutrientes e alumínio.

Nessas condições, foi possível chegar-se às seguintes conclusões:

- Os cultivares C525, C125 e C805 são os mais tolerantes à presença do alumínio no meio de cultivo;

- Os cultivares C701 e C425 são os mais sensíveis à presença do alumínio no meio de cultivo;

- O cultivar C135 apresentou pequena tolerância ao alumínio, até o nível $10 \mathrm{mg} . \mathrm{L}^{-1}$ de alumínio;

- O nível que melhor separou os cultivares tolerantes dos sensíveis foi $20 \mathrm{mg} . \mathrm{L}^{-1}$ de alumínio na solução;

- O acúmulo do alumínio no sistema radicular das plantas de milho não foram devido somente ao acúmulo de fósforo nessa parte. 


\title{
MAIZE CULTIVARS COMPARISON IN NUTRITIVE SOLUTIONS WITH ALUMINUM LEVELS
}

\author{
Author: MARIA DA CONCEIÇÃO RIVOLI COSTA
}

Adviser: Prof.Dr. QUIRINO AUGUSTO DE CAMARGO CARMELLO

\section{SUMMARY}

A experiment was conducted in greenhouse conditions at Piracicaba, São Paulo, Brazil with the objective of avaluate six maize cultivars (C125, C135, C425, C525, C701 and C805) in six levels of aluminum solutions $\left(0,10,20,30,40\right.$ and $\left.50 \mathrm{mg} . \mathrm{L}^{-1}\right)$ and to selecte more tolerant cultivars.

The plants were transplanted to polietilen boxes that containing $25 \mathrm{~L}$ of solution, seven days after the emergency in trays with washed sand. The plants were sustained on the solutions with plates of polystyrene with twelve holes. In each plate there were taking four replications of three of the six cultivars. The 
plants stained in the solutions with aluminum during the morning and afternoon and they were transported to other boxes with nutritive solutions without aluminum at night. The solutions were continuously aired. When the plants had thirty days in the solutions, they were cuted and divided in three parts: leaves, stems and roots that were dried, weighed and analised to macronutrients and aluminum.

In this conditions, was possible to take the following conclusions:

- The cultivars C525, C125 and C805 were more tolerants to aluminum in the solutions;

- The cultivars C701 and C425 were more sensitives to aluminum in the solutions;

- The cultivar $\mathrm{C} 135$ had some tolerance to aluminum until $10 \mathrm{mg} . \mathrm{L}^{-1}$ level;

- The better level to separate tolerant cultivars of sensitive ones was $20 \mathrm{mg} . \mathrm{L}^{-1}$ of aluminum in solution;

- Aluminum accumulation in the root sistem is caused not only by phosphorus accumulation in this part. 


\section{INTRODUÇÃO}

O milho ( Zea mays $L$. ) é um a gramínea de ciclo anual originária do Continente Americano que, pelas suas múltiplas utilizações, constitui-se um dos cereais mais cultivados no mundo.

Além de seu grande valor econômico, a cultura do milho ocupa lugar de destaque nas pesquisas técnico-cientificas, com resultados que além de terem contribuido para o aperfeiçoamento de seu cultivo, também influenciaram nas técnicas empregadas em outras culturas.

Atualmente, a cultura ocupa o terceiro lugar entre os cereais mais cultivados do mundo, sendo superado apenas pelo trigo e pelo arroz. Entre os principais produtores mundiais estão o Brasil, Estados Unidos da América, Rússia e China, sendo que no ano de 1977, o Brasil foi o primeiro produtor mundial, em área cultivada, devido ao avanço na agricultura e à suinocultura.

A toxicidade de alumínio pode constituir um dos principais obstáculos ao sucesso da exploração agrícola dos solos com elevada acidez subsuperficial. Assim, a presença de níveis elevados de alumínio, acarretando inibição do crescimento radicular das plantas, pode tornar-se limitante à produção, sobretudo sob condições de períodos curtos de deficiência hídrica (veranicos). Dessa forma, sendo confinado às camadas superficiais do solo, o 
desenvolvimento do sistema radicular impede o aproveitamento, pelas plantas, de água e nutrientes contidos na subsuperfície.

A correção da acidez do solo através da calagem, é a prática mais recomendada para que as plantas possam aproveitar a água e os nutrientes, porém não é eficiente na correção da acidez em profundidade.

A seleção de cultivares tolerantes pode ser realizada a campo ou em solução nutritiva, apresentando esta última, as vantagens: a) homogeneidade do substrato, b) condições ambientais controláveis, c) repetição de plantio.

Este trabalho teve como objetivo, avaliar o comportamento de seis cultivares de milho ( $\mathrm{C} 125, \mathrm{C} 135, \mathrm{C} 425, \mathrm{C} 525, \mathrm{C} 701 \mathrm{e} \mathrm{C} 805$ ) quando submetidos a níveis de alumínio, em solução nutritiva, com a finalidade de selecionar os cultivares mais tolerantes ao alumínio. 


\section{REVISÃO DE LITERATURA}

\subsection{Alumínio no substrato e sua correção}

É enorme a extensão de solos ácidos nas regiões tropicais e subtropicais úmidas. O território brasileiro apresenta $20 \%$ de sua área ocupada com solos de cerrado, os quais apresentam-se ácidos e sujeitos à toxicidade do alumínio (CAMBRAIA, 1989). Nessas áreas, os processos de interuperização e lixiviação da maioria dos solos são bastante intensos, causando o empobrecimento em bases e a acidificação gradativa do perfil. Isso resulta em baixos valores de $\mathrm{pH}$, os quais possibilitam o aumento na solubilidade de certos metais, tais como o $\mathrm{Al}^{3+}, \mathrm{Fe}^{2+}, \mathrm{Zn}^{2+}, \mathrm{Mn}^{2+} \mathrm{e} \mathrm{Cu}^{2+}$.

A liberação do alumínio ocorre devido à ação de prótons $\mathrm{H}^{+}$que penetram na camada octaedral da argila, substituindo o alumínio e algumas vezes o magnésio, presente nas arestas do cristal. Esses íons, ao serem adsorvidos preferencialmente na nuvem de contra-íons do mineral de argila , dão rapidamente origem a um sistema H-Al-Argila (CAMARGO \& FURLANI, 1989).

$\mathrm{O}$ alumínio permanece na solução em condição ácida $(\mathrm{pH}=4,0)$ ou básica $(\mathrm{pH}=9,0)$. Perto da neutralidade, o alumínio pode precipitar-se na forma de hidróxido (MALAVOLTA et al., 1976).

Os íons considerados como responsáveis pela toxicidade em plantas, são os monômeros $\mathrm{Al}^{3+}$ e $\mathrm{Al}(\mathrm{OH})^{2+}$ (PAVAN \& BINGHAN, 1982), que estão presentes na faixa de $\mathrm{pH}$ entre 4,0 e 5,0 .

Segundo FURLANI \& BERTON (1992), as espécies de alumínio complexadas com os radicais fluoreto, sulfato, fosfato e orgânico apresentam 
baixa fitotoxidez, em comparação com as espécies monoméricas de alumínio, conforme relataram os trabalhos de ALVA et al. (1986), CAMERON et al. (1986), HUE et al. (1986) e KINRAIDE \& PARKER (1987 b). De acordo com KINRAIDE (1991) é problemática a identificação de espécies fitotóxicas pois: a) diversas espécies de alumínio coexistem em solução e portanto as espécies individuais não podem ser estudadas isoladas, mesmo em meio de cultura artificial; b) a atividade das espécies individuais deve ser calculada a partir de dados de equilíbrio que podem ser incertos; c) o aparecimento inesperado da forma $\mathrm{Al}_{4} \mathrm{Al}_{12}(\mathrm{OH})_{24}\left(\mathrm{H}_{2} \mathrm{O}\right)_{12}{ }^{7+}$ ou $\mathrm{Al}_{13}$, extremamente fitotóxica, pode causar interpretações errôneas de fitotoxidez de outras espécies de alumínio, especialmente de $\mathrm{AlOH}$; d) Se ions $\mathrm{H}^{+}$diminuem a fitotoxidez de alumínio ou vice-versa, então a espécie $\mathrm{AlOH}$ pode parecer fitotóxica quando não o é; e) As identidades e atividades de espécies de alumínio em contato com as superficies celulares são incertas devido ao fluxo de $\mathrm{H}^{+}$através da superficie da raiz e devido também às cargas da superfície radicular. Finalmente, o autor concluiu que alumínio policatiônico (carga maior que 2) é tão fitotóxico quanto aos demais cátions polivalentes.

WAGATSUMA \& KANEKO (1987) observaram que em uma solução contendo partes iguais de polímeros e monômeros de $\mathrm{Al}$, os polímeros

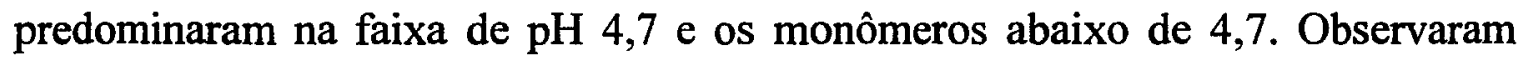
também que no $\mathrm{pH} 4,7$, o conteúdo de $\mathrm{Al}$ de uma raiz recém cortada foi máximo, enquanto que o conteúdo de $\mathrm{K}$ foi mínimo. Já em $\mathrm{pH}$ extremamente baixo, inferior a 4,5, a maior perda de $\mathrm{K}$ pelas raízes associada ao $\mathrm{pH}$ foi evitada quando o Al estava presente na solução. Os mesmos autores perceberam que a toxidez dos dois tipos de íons alumínio em relação ao crescimento radicular e à retenção de $\mathrm{K}$ pelas raízes se dá da seguinte maneira: íons polímeros- $\mathrm{Al}>$ íons monômeros- $\mathrm{Al}>$ $\mathrm{AlSO}_{4}{ }^{+}$. Constataram que o aumento da basicidade das soluções de $\mathrm{Al}$ aumentou a concentração de íons-polímeros-Al na solução, enquanto que o atraso da elongação das raízes e da perda de $\mathrm{K}$ das raízes foram assegurados. Concluíram que os íons polímeros-Al parecem ser, preferencialmente, absorvidos pelas raízes, destruindo a plasmalema das células radiculares e inibindo sensivelmente a elongação.

$\mathrm{O} \mathrm{pH}$ é o fator mais importante para o controle do $\mathrm{Al}^{3+}$ solúvel e trocável dos solos sendo que a toxicidade do alumínio é praticamente severa em 
condições de solo com $\mathrm{pH}$ abaixo de 5,0, podendo entretanto ocorrer em valores de até 5,5 .

As formas de alumínio na fase sólida, ou na fase líquida adsorvidas ou na fase líquida são de grande importância, pois nos dá idéia da fertilização dos solos. Na fase sólida, os principais minerais controladores da atividade do alumínio em solução ácida são a gibbsita, a caulinita, a montmorilonita, e a vermiculita interestratificada. Os óxidos microcristalinos ou amorfos e os fosfatos de alumínio, podem ter também papel destacado na fase sólida.

Pode-se ressaltar que se a gibbsita estiver presente no solo e o $\mathrm{pH}$ for suficientemente baixo, ela servirá para suprir o complexo de troca com alumínio trocável. Solos com caulinita e argila 2:1 com camadas de alumínio interlamelares apresentam duas vezes e meia mais aluminio que solos apenas com caulinita, mesmo tendo menor teor de argila. Camadas mais profundas do solo, com minerais interestratificados contendo alumínio, também apresentam teores mais elevados que aquelas onde aparece apenas caulinita. $\mathrm{O}$ alumínio pode encontrar-se também formando complexos com a matéria orgânica e adsorvido nos minerais do solo. Na solução do solo, uma mistura de complexos formados a partir da ligação entre alumínio e radicais inorgânicos e orgânicos é a forma mais provável de ser encontrada, sendo que em $\mathrm{pH}$ baixo, a forma hidratada $\mathrm{Al}$ $\left(\mathrm{H}_{2} \mathrm{O}\right)_{6}{ }^{3+}$ é muito importante, pois reage com água, constituindo o primeiro estágio da hidrólise. (CAMARGO \& FURLANI; 1989)

Outros fatores que podem afetar o conteúdo de $\mathrm{Al}^{3+}$ solúvel e trocável dos solos são: presença de matéria orgânica; capacidade de troca; tipo de argila presente; forma e quantidade de compostos de alumínio insolúvel; condições de umidade do solo (períodos de secas prolongadas) PRATT (1966) e presença de sais de fosfato .

EVANS \& KAMPRATH (1970) formularam a hipótese de que a matéria orgânica diminui a solubilidade do $\mathrm{Al}^{3+}$ pela formação de complexos organo-minerais. Isto explica possivelmente, o melhor comportamento das plantas em solos orgânicos do que em solos ácidos minerais.

Em presença de matéria orgânica, a hidrólise do $\mathrm{Al}^{3+}$ é mais intensa em $\mathrm{pH}$ baixo porque os produtos reagem com grupos carboxílicos, mais que com argilo-minerais e também porque a matéria orgânica serve como receptora dos íons hidrogênio produzidos na hidrólise (HARGROVE \& THOMAS, 1981). 
$\mathrm{Al}(\mathrm{O} \mathrm{O} \mathrm{C})_{3} \mathrm{R}+\mathrm{H}_{2} \mathrm{O} \leftarrow \rightarrow \mathrm{Al}(\mathrm{OH})_{2} \mathrm{R}+\mathrm{RCOOH}$

$\mathrm{Al}(\mathrm{OH})(\mathrm{O} \mathrm{OC})_{2} \mathrm{R}+\mathrm{H}_{2} \mathrm{O} \leftarrow \rightarrow \mathrm{Al}(\mathrm{OH})_{2}(\mathrm{OOC}) \mathrm{R}+\mathrm{RCOOH}$

Com o aumento da relação $\mathrm{OH} / \mathrm{Al}$, cada alumínio ocupará menos cargas negativas, deixando livres grupos adicionais para a adsorção de mais $\mathrm{Al}^{3+}$. O alumínio é um cátion de caráter ácido. Em solução, ele se hidrata e se hidrolisa, resultando na liberação da acidez em solução. Em pH abaixo de 5,5 têm-se segundo THOMAS \& HARGROVE (1984), a seguinte reação:

$\mathrm{Al}^{3+}+6 \mathrm{H}_{2} \mathrm{O} \rightarrow\left[\mathrm{Al}\left(\mathrm{H}_{2} \mathrm{O}\right)\right] 6^{3+} \stackrel{\mathrm{H}_{2} \mathrm{O}}{\longrightarrow} \mathrm{H}_{3} \mathrm{O}++\left[\mathrm{Al}\left(\mathrm{H}_{2} \mathrm{O}\right)_{5} \mathrm{OH}\right]^{2+}$

As reações de hidrólise do $\mathrm{Al}^{3+}$ são representadas esquematicamente a seguir ( CAMARGO \& FURLANI, 1989):
$\mathrm{Al}\left(\mathrm{H}_{2} \mathrm{O}\right)_{6}{ }^{3+}+\mathrm{H}_{2} \mathrm{O}$
$\leftarrow \rightarrow$
$\mathrm{Al}(\mathrm{OH})\left(\mathrm{H}_{2} \mathrm{O}\right)_{5}^{2+}+\mathrm{H}_{3} \mathrm{O}^{+}$
$\mathrm{Al}(\mathrm{OH})\left(\mathrm{H}_{2} \mathrm{O}\right) 5^{2+}+\mathrm{H}_{2} \mathrm{O}$
$\leftarrow \rightarrow \mathrm{Al}(\mathrm{OH})_{2}\left(\mathrm{H}_{2} \mathrm{O}\right)_{4}^{+}+\mathrm{H}_{3} \mathrm{O}^{+}$
$\mathrm{Al}(\mathrm{OH})_{2}\left(\mathrm{H}_{2} \mathrm{O}\right)_{4}^{+}+\mathrm{H}_{2} \mathrm{O}$
$\leftarrow \rightarrow$
$\mathrm{Al}(\mathrm{OH})_{3}\left(\mathrm{H}_{2} \mathrm{O}\right)_{3} \mathrm{O}+\mathrm{H}_{3} \mathrm{O}^{+}$
$\mathrm{Al}(\mathrm{OH})_{3}\left(\mathrm{H}_{2} \mathrm{O}\right)_{3} \mathrm{O}+\mathrm{H}_{2} \mathrm{O}$
$\leftarrow$
$\mathrm{Al}(\mathrm{OH})_{4}\left(\mathrm{H}_{2} \mathrm{O}\right)_{2}^{-}+\mathrm{H}_{3} \mathrm{O}^{+}$

RAGLAND \& COLEMAN (1960) relataram que o grau de hidrólise aumentaria na presença de argila, quando comparado com uma solução aquosa de um sal de alumínio. Mas há controvérsias entre os autores, porque FRINK \& $\mathrm{PEECH}$ (1963) estudando a seletividade da adsorção de $\mathrm{Al}^{3+}, \mathrm{Al}(\mathrm{OH})^{2+} \mathrm{e} \mathrm{H}^{+} \mathrm{e}$ da razão $H / A l$ na suspensão de argila, concluíram que o grau de hidrólise foi reduzido na presença da mesma.

No solo, o alumínio causa a diminuição da disponibilidade de $\mathrm{N}$ e $\mathrm{P}$ combinando-se com o nutriente e causando a sua precipitação ou diminuindo a sua solubilidade. Há ainda indícios de que o alumínio diminui a absorção de nitrato, ferro, manganês e enxofre (JACKSON 1963).

Na planta, o alumínio tem pequena mobilidade, segundo ANDREW \& BERG 1973, concentrando-se mais nas raízes do que na parte aérea, sendo que 
os íons polímeros- $\mathrm{Al}$ podem ser mais tóxicos às plantas do que os íons monômeros-Al (WAGATSUMA \& EZOE, 1985).

Os efeitos fitotóxicos causados por uma concentração fixa de $\mathrm{Al}^{3+}$ são altamente dependentes não somente de características do meio de crescimento das plantas, como $\mathrm{pH}$, concentrações de sais, compostos orgânicos, temperatura como também da espécie vegetal e/ou do cultivar utilizado. Os fatores químicos do substrato (solução do solo e/ou solução nutritiva ) acarretam alterações sensíveis na atividade das várias espécies de íons $\mathrm{Al}^{3+}$ em solução e, conseqüentemente podem alterar a intensidade dos efeitos fitotóxicos do $\mathrm{Al}^{3+}$.

Segundo RAIJ (1988), o alumínio é o principal elemento tóxico associado à acidez dos solos, sendo que seu efeito reflete-se nas raízes, que as tornam mais lentas em alongar-se. Mais tarde elas engrossam e não se ramificam normalmente e as pontas das raízes desintegram-se e adquirem cor marrom.

No Brasil o assunto adquire importância muito grande, pela ocorrência generalizada de alumínio trocável na maioria dos solos (OLMOS \& CAMARGO, 1976). A importância do alumínio, como o principal componente da acidez dos solos, é tão grande que o alumínio trocável foi proposto como critério para recomendação de calagem em solos muito lixiviados (KAMPRATH, 1970).

A calagem pode resolver o problema do alumínio na camada superficial do solo, pois seu efeito neutraliza o alumínio e aumenta a proliferação de raízes, mas não é tão eficaz para resolver o problema nas camadas profundas (RAIJ, 1988).

Segundo FAGERIA (1982), a seleção de genótipos quanto à tolerância ao alumínio pode ser realizada no campo, em solos ácidos, submetidos à doses de calcário, para a obtenção de níveis de saturação por alumínio. A desvantagem da utilização dos solos é a impossibilidade de se isolar e controlar quantitativamente os fatores de acidez, sendo os resultados freqüentemente afetados, pela variabilidade do solo e pela diferente resistência dos cultivares às doenças e pragas.

Para superar essas dificuldades, utilizam-se métodos de seleção rápida, em casa-de-vegetação utilizando solução nutritiva, onde um grande número de genótipos pode ser avaliado sob condições controladas (HOWELLER \& CADAVID, 1976 e MOORE et al., 1976). 
McLEAN \& GILBERT (1927) observando sintomas de toxidez de alumínio em 12 espécies vegetais cultivadas em solução nutritiva, verificaram que em todas elas, as primeiras evidências de injúrias apareciam primeiramente nas raizes, as quais se tornavam descoloridas e paravam seu crescimento. A parte aérea era afetada muito depois.

$\mathrm{O}$ efeito primário da toxicidade de $\mathrm{Al}$ em trigo, num cultivar sensível é a paralização irreversível do crescimento radicular (KERRIDGE, 1969). LIEBIG Jr. et al. (1942) encontraram menos alumínio na parte aérea de plantas desenvolvidas em presença do elemento do que nas testemunhas. $O$ alumínio acumulou-se nas raízes, não translocando-se para a parte aérea das plantas tratadas.

Experimentos mostram que a adição de $\mathrm{Al}^{3+}$ à solução nutritiva causa aumento na absorção de fosfato pelas raízes (RANDALL \& VOSE, 1963). Há acumulo de $\mathrm{Al}^{3+}$ e $\mathrm{P}$, embora não tenha sido provado que os elementos estejam combinados com os fosfatos de alumínio.

MUNNS (1965), aplicando o princípio do produto de solubilidade, demonstrou que a concentração de alumínio diminui com adição de fósforo ao solo. A interação Al x P em nutrição de plantas pode ser explicada, em parte, pela interação química entre os dois elementos, que formam um composto pouco solúvel. Se a concentração de um dos componentes do sal aumenta, o princípio do produto de solubilidade determina o abaixamento do teor do outro componente. Segundo o mesmo autor, o princípio do produto de solubilidade se aplica em uma larga faixa de $\mathrm{pH}$, mas só é significativo em relação à toxidez de alumínio em valores baixos de $\mathrm{pH}$. Conseqüentemente, as plantas podem estar afetadas por deficiência de fósforo em valores altos de $\mathrm{pH}$, sem que ao mesmo tempo, sejam afetadas por toxidez de alumínio.

FOY et al. (1967a) determinaram que variedades de trigo e cevada sensíveis ao alumínio possuíam raízes com capacidade de troca de cátions maior do que as variedades resistentes, resultando em abaixamento do $\mathrm{pH}$ das soluções nutritivas. Variedades sensíveis continham mais alumínio nas raizes e menos cálcio na parte aérea.

BRAUNER \& SARRUGE (1980) também encontraram aumentos, pelo efeito do alumínio, na absorção de $\mathrm{P}$ em trigo. Entretanto, as diferenças 
genéticas quanto à absorção de P não se relacionaram com o grau de tolerância ao alumínio das cultivares estudadas.

Segundo JACKSON (1967), os sintomas da deficiência de $P$ freqüentemente observados no crescimento das culturas em solos ácidos, podem ser resultado da imobilização do $\mathrm{P}$ na raiz das plantas e nos tecidos de condução. OHKI (1975) relatou que altos conteúdos de $\mathrm{P}$ nas folhas de algodoeiro estavam associados aos baixos índices de $\mathrm{Mn}$. Igualmente, fazendo a calagem nos solos ácidos do Hawaii diminuiu-se o conteúdo de $\mathrm{Mn}$ dos pestílos em mamão enquanto o conteúdo de $\mathrm{P}$ aumentava (AWADA et al., 1975). Então parece haver ampla evidência que sustenta a generalização de que fazendo a calagem excessiva em solos tropicais tem pouco ou nenhum efeito na solubilidade do $\mathrm{P}$, mas pode ter bons efeitos no suprimento de P para as plantas (JONES \& FOX, 1978).

Em experimentos conduzidos com soja em solução nutritiva, CASTELL et al. (1985), notaram que o alumínio estimulou e elevou a velocidade de absorção de P na soja . Esse fato também foi verificado por RANDALL \& VOSE (1963).

TRENEL \& ALTEN (1934), trabalhando com milho e utilizando a técnica de raízes divididas, determinaram que os efeitos de toxidez de alumínio apareciam primeiramente nas raizes em contato com o elemento, as quais paralizavam o crescimento, enquanto as raízes fora do alumínio cresciam normalmente.

A acidez natural dos solo, o desenvolvimento industrial bem como o uso indiscriminado de certos fertilizantes, têm contribuído para a acidificação de áreas agricultáveis, que anteriormente não estavam sofrendo o problema de toxidez de alumínio CAMBRAIA (1989).

Segundo RAIJ (1988), a calagem pode resolver o problema do alumínio na camada superficial do solo, mas não é tão eficaz para resolver o problema nas camadas profundas. Esse mesmo autor, sugeriu o uso do gesso, devido à facilidade que o mesmo apresenta em movimentar-se para camadas subsuperficiais do solo, mas reconhece que, os resultados tem sido conflitantes na literatura, necessitando mais estudos.

PAVAN et al. (1987) demonstraram que o gesso agrícola, em comparação com cloreto de cálcio, acarretou maior aumento na forma iônica e diminuiu a atividade de $\mathrm{Al}^{3+}$ do extrato de saturação de um Cambissolo, 
culminando com uma melhor proliferação de raizes de macieira. No solo tratado com gesso agrícola a concentração de $\mathrm{AlSO}_{4}{ }^{+}$representou $48 \%$ do alumínio total. Isto deve ter contribuído para a drástica redução da atividade de alumínio e conseqüentemente para a melhoria do desenvolvimento radicular da macieira.

Em geral, os efeitos nocivos do alumínio nas plantas refletem-se nas raízes que se tornam mais lenta em alongar-se, e portanto, a prática cultural da calagem tem sido das mais utilizadas para solucionar o problema da elevada acidez de certos solos. A sua aplicação, contudo, geralmente se restringe às camadas superficiais do solo. Em camadas sub-superficiais torna-se mais dificil e antieconômica, pois a movimentação do calcário é lenta e por conseguinte, o crescimento de raízes é reduzido e a planta torna-se muito pouco eficiente no aproveitamento de água e nutrientes. Portanto, para o melhor aproveitamento das fertilizações e o conseqüente aumento na produtividade por unidade de área , é sem dúvida, necessária a correção da acidez nociva do solo.

A neutralização do $\mathrm{Al}^{3+}$ trocável, além de bloquear sua ação tóxica, evita também a fixação do fósforo na forma de fosfatos insolúveis de alumínio (OLMOS \& CAMARGO, 1976). HARTWELL \& PEMBER (1918) foram os primeiros a demonstrar o efeito da adubação fosfatada na redução dos efeitos tóxicos de $\mathrm{Al}^{3+}$ sobre o crescimento de plantas.

$\mathrm{O} \mathrm{Al}^{3+}$ trocável, além de ser um elemento nocivo ao desenvolvimento do sistema radicular, interfere na absorção e na movimentação do $\mathrm{P}, \mathrm{Ca}, \mathrm{Mg}, \mathrm{Mo}$, contribuindo também para a fixação do P. Portanto, maiores quantidades desse elemento são necessárias para compensar as deficiências.

A presença de $\mathrm{Al}^{3+}$ no solo em níveis tóxicos para as culturas é comum em grande extensão das áreas agrícolas brasileiras. A correção do solo, na camada superficial, aliada ao uso de cultivares tolerantes, oferece uma solução satisfatória e econômica para o problema (BAHIA FILHO et al.,1978).

De acordo com KAMPRATH (1967), a produção da maioria das plantas sensíveis à toxidez de alumínio decresce em solos com mais de $20 \%$ de saturação por alumínio. Segundo LOPES (1983), cerca de 78,6\% dos solos sob vegetação de cerrado estão incluídos nessa categoria, enfatizando uma vez mais, a necessidade de calagem adequada para corrigir o $\mathrm{pH}$, reduzir a saturação por alumínio, fornecer $\mathrm{Ca}^{2+} \mathrm{e} \mathrm{Mg}^{2+}$ como nutrientes, e todos os demais beneficios dessa prática de manejo. 
No milho, o crescimento em extensão do sistema radicular é muito influenciado pelo suprimento de carboidratos produzidos e acumulados na parte aérea, mas esse suprimento está relacionado com a quantidade de nutrientes disponíveis na solução do solo. Portanto, há necessidade de que o sistema radicular não seja danificado, possibilitando a proliferação intensa das raízes, com reflexos positivos no crescimento das mesmas.

\subsection{Alumínio na planta}

A presença de alumínio em níveis considerados fitotóxicos na solução é um fator que limita em muito o crescimento das plantas, pois atua essencialmente sobre o sistema radicular modificando sua anatomia.

Os efeitos mais drásticos e típicos da fitotoxidade do $\mathrm{Al}^{3+}$ ocorrem nas raízes, que são as partes das plantas mais afetadas pelo excesso desse elemento no meio de crescimento (RHUE, 1977; FURLANI, 1989).

Na planta, o efeito do $\mathrm{Al}^{3+}$ é devido principalmente à alteração de permeabilidade das células da raiz (FOY \& BROWN, 1964; BOLLARD \& BUTTER, 1966). Entretanto, o sintoma mais característico da toxicidade do alumínio é a inibição da divisão celular na região meristemática da raiz, causando a morte do ápice e o desenvolvimento de raízes laterais (CLARKSON, 1965, 1969). Isto ocorre devido à interferência do alumínio no processo metabólico, associado à divisão celular e à replicação do DNA durante a interfase. $\mathrm{O}$ alumínio interfere no metabolismo dos compostos fosforilados, inibe a atividade da enzima hexoquinase e afeta a síntese de DNA (CLARKSON, 1966 a, 1969).

WAGATSUMA et al. (1987) observaram que do alumínio absorvido no ápice das raízes, grande parte se liga ao núcleo das células, ao $\mathrm{P}$ e ao DNA, resultando em diminuição da divisão celular, e finalmente em inibição dessa divisão.

O alumínio liga-se ao DNA, mas é baixa a sua penetração no DNA mitoticamente ativo. A duplicação do DNA é reduzida devido ao aumento da rigidez da dupla hélice (FOY, 1992).

Na parte aérea das plantas, muitas vezes, os sintomas de toxidez de $\mathrm{Al}^{3+}$ não são claramente diagnosticados (FOY, 1984; TAYLOR, 1988 b), sendo mais facilmente observados, na fase inicial de desenvolvimento da planta, quando 
apresentam coloração verde-pálido nas folhas e redução no comprimento de raízes, com engrossamento secundário (VOSE, 1987).

Em algumas espécies, os sintomas foliares são semelhantes aos de deficiência de $\mathrm{P}$ ou seja, há um atrofiamento generalizado, as folhas tornam-se pequenas e há a ocorrência de um avermelhamento de caule e nervuras. Em outras espécies, o conjunto de sintomas de toxidez de $\mathrm{Al}^{3+}$ confunde-se com os de deficiência de $\mathrm{Ca}^{2+}$, constatando-se o enrolamento de folhas novas e morte das pontas de crescimento ou dos pecíolos, podendo também ocorrer clorose internerval típica de deficiência de ferro. Em plantas de aveia, o alumínio interfere na redução do $\mathrm{Fe}^{3+}$ para $\mathrm{Fe}^{2+}$, um processo essencial para o metabolismo normal do ferro (ROY et al., 1988). Em aveia, a primeira evidência da toxicidade do $\mathrm{Al}^{3+}$ manifesta-se através do encurtamento e da injúria nas raizes (McLEAN \& GILBERT, 1927).

Algumas espécies de plantas cultivadas em solução nutritiva contendo $\mathrm{Al}^{3+}$ podem apresentar murchamento de folhas típico da deficiência hídrica. Segundo CAMBRAIA (1989), os efeitos tóxicos do $\mathrm{Al}^{3+}$ são variados e os sintomas nem sempre são facilmente identificáveis. Na parte aérea, os sintomas assemelham-se àqueles de deficiência de $\mathrm{P}, \mathrm{Fe}, \mathrm{Ca}$ ou de outros elementos minerais.

Apesar das múltiplas ações do $\mathrm{Al}^{3+}$, as causas fisiológicas da toxidez permanecem ainda obscuras (FOY, 1974) e as relações de causa e efeito muitas vezes são duvidosas. Segundo esse mesmo autor, os principais sintomas, entretanto, aparecem no sistema radicular. Além de provocar uma diminuição da divisão celular, $\mathrm{o} \mathrm{Al}^{3+}$ reduz o alongamento radicular, ficando as raizes curtas, grossas, quebradiças e, quase sempre, com uma cor amarronzada. Os sintomas visuais, entretanto, apenas refletem as inúmeras interferências que o $\mathrm{Al}^{3+}$ exerce sobre íons e/ou moléculas, processos e estrutura celulares em diferentes graus de intensidade e complexidade.

Os efeitos mais drásticos e típicos da fitotoxidez de $\mathrm{Al}^{3+}$ ocorrem nas raízes, que são as partes mais afetadas pelo excesso do elemento no meio de crescimento (FURLANI, 1989). Há uma inibição da elongação do eixo principal e as raizes tornam-se engrossadas, inchadas, com coloração castanha, quebradiças e ocasionalmente com manchas necróticas (FOY, 1992). As raízes de plantas estressadas por $\mathrm{Al}^{3+}$ apresentam como principais características: o início de 
emissão de raízes próximas ao ponto de crescimento da raiz principal e a inibição do crescimento de raízes laterais. Como consequência, o sistema radicular fica desprovido de raízes finas, reduzido em tamanho e com aparência de corais (FOY 1984; MALAVOLTA et al. 1989). Em geral, os efeitos prejudiciais do $\mathrm{Al}^{3+}$ sobre as plantas refletem-se principalmente nas raizes, que tornam-se mais lentas em alongar (RAIJ, 1988). Mais tarde, elas engrossam e não se ramificam normalmente, as pontas das raízes desintegram-se e adquirem cor marrom. As raízes adventícias proliferam-se enquanto a coroa da planta estiver viva (REID, 1976).

$\mathrm{Na}$ maioria dos cereais, os sintomas de injúria provocados pelo alumínio são observados inicialmente nas raízes, que se alongam pouco e apresentam pequena ramificação, com posterior engrossamento, desintegração apical e aparecimento da coloração marrom (MINELLA, 1989).

Em plantas de milho, CLARK (1977) observou que as injúrias no sistema radicular, devido ao $\mathrm{Al}^{3+}$, surgiram mais nas raizes adventícias, porém elas não se alongaram . Elas também produziram menos fibras radiculares do que as raízes normais. Os efeitos tóxicos do $\mathrm{Al}^{3+}$ sobre as plantas, observados por WAGATSUMA et al. (1987), tiveram inicialmente lugar nas raizes, sendo que pequenas quantidades de $\mathrm{Al}^{3+}$ puderam inibir a elongação da raiz em poucos dias. A inibição iniciou pela raiz principal, depois pela secundária e finalmente, as raizes assumiram forma de corais.

Em estágios mais avançados de toxidez, a parte aérea também é danificada, existindo correlação estreita entre peso das raízes e da parte aérea das plantas. Em soluções com concentrações muito altos de $\mathrm{Al}^{3+}$, mesmo as plantas mais tolerantes podem sofrer danos (RAIJ, 1988). Os danos causados pelo $\mathrm{Al}^{3+}$ em plantas são muitas vezes caracterizados pela redução na absorção de $\mathrm{Ca}^{2+} \mathrm{e}$ por sintomas semelhantes àqueles de absoluta deficiência em Ca (LONG \& FOY, 1970).

FOY et al. (1967b) apontaram que os cultivares de feijão diferem muito em crescimento da parte aérea e das raízes em solos ácidos (pH 4,4) e em suas respostas à calagem, salientando que provavelmente a toxidez de alumínio seja o principal fator na limitação do crescimento, e que certos cultivares diferem em sua tolerância ao alumínio. Com poucas exceções, os cultivares do Sul e Leste dos EUA mostram raízes mais profundas em subsolos ácidos e com níveis 
elevados de alumínio e fariam melhor uso da água e nutrientes das camadas mais profundas do solo.

$\mathrm{O}$ fato do $\mathrm{Al}^{3+}$ trocável do solo (FOY et al., 1973) reduzir a absorção do $\mathrm{Ca}$ pelas plantas, para o caso específico do tomateiro, o $\mathrm{Al}$ pode também induzir ou intensificar a desordem nutricional clássica conhecida como podridão apical do fruto do tomate ("Blossom-and-rot").

BAUMGARTNER et al. (1988) afirmaram que o tomateiro é indicado como planta teste para o alumínio, pois é uma cultura muito sensível ao alumínio em solos ácidos.

Experimentos mostram que a adição de alumínio à solução nutritiva causa aumento na absorção de fosfato pelas raízes (RANDALL \& VOSE, 1963). BLACK (1968) verificou que há acumulo de alumínio e fósforo, embora não tenha sido provado que os elementos estejam combinados com fosfato de alumínio. Em trabalho feito com Stylosanthes humilis, MOSQUIM (1978) encontrou que os teores de $\mathrm{P}$ da parte aérea e, principalmente, do sistema radicular, aumentaram progressivamente com a elevação da concentração de alumínio, até $10 \mathrm{ppm}$ na solução nutritiva. Resultados semelhantes foram obtidos por OLIVEIRA (1979), em mandioca.

Em plantas com injúrias devidas ao alumínio, os sintomas manifestam-se nas folhas jovens, as quais ficam pequenas, encrespadas ao longo das margens e cloróticas, enquanto as folhas velhas mostram clorose marginal, que progride para o centro (PAVAN \& BINGHAN, 1982). Esses autores observaram a redução no crescimento da parte aérea em plantas de café, após o tratamento com $\mathrm{Al}^{3+}$.

$\mathrm{O}$ alumínio, na forma iônica $\mathrm{Al}^{3+}$, afeta inúmeros processos citológicos, bioquímicos e fisiológicos da maioria das espécies cultivadas (JONES, 1961, CLARKSON, 1969; MALAVOLTA et al., 1977; FOY et al. 1978).

Segundo FURLANI (1983), os efeitos fitotóxicos do $\mathrm{Al}^{3+}$ são mais evidentes nas raízes, onde ocasiona a inibição da divisão celular, a fixação do $\mathrm{P}$ para formas menos disponíveis, a diminuição da taxa de respiração, interferências em reações enzimáticas que governam a deposição de polissacarídeos nas paredes celulares, e a alteração na absorção, transporte e uso de diversos nutrientes, notadamente $\mathrm{Ca}, \mathrm{Mg}$ e $\mathrm{P}$. 
A maior parte do alumínio da raiz está ligada às substâncias pécticas da parede celular, enquanto uma parte do alumínio penetra no protoplasma e se combina com os ácidos nucleicos e ácidos solúveis de fosfato (WAGATSUMA, 1983a). Ao nível celular, um dos primeiros sinais do estresse de alumínio é a desorganização da membrana plasmática. Freqüentemente, as células da coifa da raiz tornam-se vacuoladas, com interrupção da função do aparelho de Golgi e do desenvolvimento de plastídeos; sofrem alterações na estrutura nuclear e perdas de citoplasma e finalmente, a desintegração. As células da epiderme, da endoderme e corticais afetadas por $\mathrm{Al}^{3+}$ rapidamente se autolizam, tornando-se inchadas e desorganizadas. As regiões meristemáticas das raízes primárias e laterais desorganizam-se, a ponto de tornar-se difícil a distinção entre a coifa e os elementos vasculares. Os pontos de erupção dos pêlos absorventes sua base, falham em cicatrizarem-se normalmente (FOY, 1988; TAYLOR 1988a).

RORISON (1958) atribuiu a inibição do desenvolvimento de pêlos radiculares à reação entre o alumínio e substâncias pécticas das paredes de células jovens, causando perda de plasticidade e inibição na elongação. Diversos trabalhos têm procurado localizar na planta os processos sensiveis à ação tóxica do alumínio. Alguns desses trabalhos mostram que níveis elevados de alumínio inibem a divisão e o alongamento celular (CLARKSON, 1965; KLIMASHEVSKY et al., 1970).

Em plantas de aveia e arroz, o alumínio induz várias mudanças morfológicas na superfície radicular, com a ocorrência de um grande número de pequenas depressões no ápice e na região de elongação (WAGATSUMA et al., 1987). ANDERSON \& EVANS (1956) constataram que o alumínio diminui a atividade da isocítrico-desidrogenase e da enzima málica. Reduz a fosforilação dos açúcares (RORISON, 1965), dificultando a utilização da sacarose e a formação de polissacarídeos na parede celular (HUCK, 1972), afetando a síntese e o teor dos aminoácidos na planta (KLIMASHEVSKY et. al., 1970). Em plantas de arroz (ROY et al., 1988), o alumínio pode provocar diminuição no teor de clorofila, com um decréscimo marcante na fotossíntese bruta e liquida.

A atividade respiratória das plantas pode ser inibida (CLARKSON, 1969 e FOY, 1992), devido à diminuição do requerimento de energia metabólica, enquanto a síntese de proteínas é reduzida, provavelmente, devido ao efeito do $\mathrm{Al}^{3+}$ sobre a distribuição dos ribossomas no retículo endoplasmático (ROY et al., 
1988). CLARKSON (1969) encontrou reduções de $35 \%$ na respiração das raízes de Onolicichis sativa pré-tratadas com alumínio por três horas, mas sugeriu que esse pode ser um efeito secundário da redução sobre a absorção do cálcio e de outros nutrientes.

Em arroz, a intensidade respiratória diminui com o aumento no suprimento de alumínio, seguido pela diminuição no teor de glicídeos solúveis, inclusive açúcares redutores (ROY et., al. 1988). Em estudos com milho, CLARK \& BROWN (1974) demonstraram diferenças genotípicas marcantes quanto à taxa de absorção de $P$, em linhagens cultivadas em soluções nutritiva, com baixo teor de $\mathrm{P}$, quando na presença e na ausência de alumínio. A linhagem que apresentou maior capacidade de absorção e acumulação de $\mathrm{P}$, revelou ter maior habilidade em manter o pH mais alto na região da rizosfera.

Alguns cultivares tolerantes de trigo, cevada, ervilha e milho, promoveram o aumento do $\mathrm{pH}$ da solução nutritiva e assim diminuiram a solubilidade e a toxicidade do alumínio, por precipitação (FOX \& KANG, 1978). As alterações nos valores do $\mathrm{pH}$ da zona radicular estão associadas aos processos ativos de absorção iônica, com a subseqüente liberação de íons $\mathrm{H}^{+}$e $\mathrm{OH}^{-}$, hidrólise de $\mathrm{CO}_{2}$ e a absorção relativa de ânions e cátions (MOORE, 1974).

FURLANI \& FURLANI (1988) estudaram a variação do $\mathrm{pH}$ das soluções nutritivas, em função do comportamento diferencial de genótipos de arroz, milho e sorgo tolerantes e sensiveis ao alumínio. Constataram que na primeira semana de cultivo, os valores de $\mathrm{pH}$ decrescem com o tempo de permanência das plantas na solução nutritiva, contendo ou não alumínio. Após esse período, ocorreu estabilização do $\mathrm{pH}$ para arroz e sorgo e elevação para milho. Entretanto, associações entre as alterações de $\mathrm{pH}$ na solução nutritiva e as diferenças na tolerância ao alumínio tem sido discretas na literatura, para cultivares de milho (CLARK \& BROWN, 1974), quando cultivados em solução nutritiva contendo alumínio. Cultivares tolerantes ao alumínio induzem à elevação nos valores de $\mathrm{pH}$ da solução nutritiva, ocorrendo o contrário para os cultivares sensíveis ao alumínio.

Estudos sobre a tolerância ao alumínio demonstraram, que há grandes diferenças entre espécies e mesmo entre cultivares, sobre o crescimento e o desenvolvimento, tanto em solução nutritiva, quanto em solos com altos níveis de alumínio trocável (FOY \& BROWN, 1964). A natureza dessa tolerância 
diferencial ao alumínio não está clara, devido à diversidade dos seus efeitos na planta. Acredita-se que ela possa ser controlada por diferentes gens, através de várias vias bioquímicas (FOY \& FLEMING, 1978). Obviamente, as plantas devem ser capazes de controlar a absorção do excesso de alumínio ou então de impedir a sua ação tóxica após ter sido absorvido.

É possível supor que a maioria das plantas acumuladoras de $\mathrm{Al}^{3+}$ (GOODLAND, 1971) sejam encontradas nos solos de cerrado do Brasil e nos semi-tropicais em geral, pois são caracterizados pelo alto nível de alumínio. Entre elas encontram-se: Qualea grandiflora (pau-terra), Qualea pariflora (pauterrinha), Qualea multiflora (pau-terra vermelha), Phychotria sp, Palicourea $s p$ e Antonia sp. A tolerância pode ser diferente para espécies e cultivares, e parece ser controlada por mais do que um gen (FOY et al., 1978). Há evidências no sentido de que plantas acumuladoras tem um mecanismo baseado em ação diferencial de enzimas para metabólitos e o composto tóxico análogo.

Estudos realizados em genótipos de milho, ervilha, arroz, aveia e cevada, que diferem quanto à tolerância ao $\mathrm{Al}^{3+}$, sugerem que uma menor negatividade da superfície da plasmalema das células radiculares pode determinar uma menor ligação com o alumínio, e em consequência, a tolerância ao metal (WAGATSUMA \& AKIBA, 1989). O alumínio se acumula no citoplasma e no núcleo de células corticais das raízes de plantas sensíveis e tolerantes (McLEAN \& GILBERT, 1927).

As plantas sensíveis tem as cargas da superfície da plasmalema fortemente ligada ao alumínio, podendo a membrana eventualmente ser destruída. A negatividade das raizes de plantas jovens é maior do que em plantas adultas (WAGATSUMA et al., 1987). Isto conseqüentemente faz com que plantas jovens sejam mais afetadas pelo alumínio do que plantas mais velhas, pois a força de exclusão do alumínio pela plasmalema das células radiculares de plantas de espécies tolerantes, é mais forte do que nas plantas de espécies sensíveis ao alumínio (WAGATSUMA \& EZOE , 1985).

As reações das plantas ao $\mathrm{Al}^{3+}$ são diversa. JONES (1961) sugeriu que os ácidos orgânicos das plantas podem agir como agentes quelantes, os quais complexam quantidades que seriam tóxicas de alumínio, tornando-o metabolicamente inativo. HUTCHINSON (1945) determinou a presença de succinato de alumínio em Orites excelsa. Algumas plantas são capazes de 
acumular alumínio é o caso de um carvalho australiano que contem alumínio depositado na forma de succinato. As cinzas do tronco dessas árvores, contem cerca $50 \%$ de alumínio. Análises de folhas de Symplocos tinctoria mostraram concentrações de 3 a 45\% no material seco (BEAR, 1964).

Como era de se esperar, muitas plantas tropicais suportam maiores concentrações de alumínio trocável no solo, como certas culturas e a maioria das gramíneas forrageiras, por exemplo, as do gênero Digitaria, como o capimpangola, e as do gênero Panicum, como o capim-colonião. Outras até necessitam de algum alumínio, como todas as do gênero Andropogon, a que pertence o capim-de-cheiro, o capim-caninha e a braquiária (PRIMAVESI, 1982). Para FOY (1988), cultivares adaptados a solos ácidos tem capacidade de troca de cátions (CTC) na raiz relativamente menor. A maior CTC das raízes é responsável por maiores conteúdos de $\mathrm{Al}^{3+}$ e $\mathrm{P}$ nesse órgão e menores conteúdos de $\mathrm{Ca}$ na parte aérea, em cultivares sensíveis de trigo e cevada (FOY et al., 1967a).

Como consequência das alterações no desenvolvimento das raízes, $o$ sistema radicular como um todo, é pouco desenvolvido e, em condições de campo pode acarretar reduções significativas na capacidade de explọração da água e dos nutrientes contidos nas camadas subsuperficiais do solo, induzindo maior suscetibilidade das plantas às deficiências hídrica e nutricional durante curtos período de estiagem (verânicos), com reflexos negativo na produtividade.

O sistema radicular do milho representa um importante componente estrutural e funcional da planta. A falta de raízes profundas e com ramificações inadequadas, significa sempre uma maior suscetibilidade à seca e uma menor capacidade de utilização dos nutrientes do solo. Portanto, as influências negativas do alumínio como sendo o causador da acidez dos solos sob vegetação de cerrado e sua deficiência mineral varre o mundo, colocando-o como o inimigo número um de todas as culturas e plantações (GONÇALVES et al., 1992).

\subsection{Efeito do alumínio sobre o metabolismo dos nutrientes nas plantas}

Sabe-se que o alumínio exerce efeitos negativos nas plantas, interferindo nos processos de absorção e metabolismo de nutrientes. Trabalhos conduzidos com várias espécies têm demonstrado que em plantas sensiveis, o 
alumínio causa normalmente sérios distúrbios na absorção dos nutrientes minerais, e que sob efeito de níveis tóxicos, os tecidos das plantas apresentam normalmente teores reduzidos de $\mathrm{Ca}, \mathrm{Mg}, \mathrm{P}$ e N (LEE, 1971; FOY et al. 1972; ANDREW \& BERG, 1973). Há evidências que outros nutrientes também sejam afetados pelo estresse de alumínio. Assim, ROY et al. (1988) constataram a interferência do mesmo em uma maior ou menor absorção de nutrientes, tais como $\mathrm{Cu}, \mathrm{Zn}, \mathrm{Mn}$ e Fe. Esses efeitos dependem da espécie vegetal, do cultivar, das condições experimentais e do grau de estresse de alumínio (FURLANI, 1989).

FOY \& BROWN (1964) e MUNNS (1965) evidenciaram que os sintomas foliares de toxidez de alumínio eram semelhantes àqueles da deficiência de fósforo. TAYLOR (1988 b) observou que, mesmo que a ocorrência de deficiências minerais induzida pelo alumínio não explique os efeitos tóxicos rápidos que são observados em plantas, os exames minuciosos da influência do alumínio no metabolismo mineral tem revelado que tais efeitos rápidos podem originar-se de alterações no metabolismo iônico, sem que os mesmos estejam ligados à indução de deficiência mineral.

$\mathrm{O}$ alumínio trocável interfere na absorção e na movimentação de $\mathrm{P}$, $\mathrm{Ca}, \mathrm{Mg}$, Mo (OLMOS \& CAMARGO, 1976) e outros elementos essenciais ao vegetal (LANCE \& PEARSON, 1969; FOY, 1974). Dentro das células, ele provoca distúrbios generalizados sobre o metabolismo de $\mathrm{P}, \mathrm{N}$ e Ca (FOY, 1978).

CLARK (1977) observou que o crescimento, o suprimento e a acumulação de elementos minerais são intensamente alterados em plantas que crescem na presença de $\mathrm{Al}$. A redução no $\mathrm{P}$ e no $\mathrm{Ca}$ são os efeitos mais comumente relacionados à toxidez pelo $\mathrm{Al}$, mais interferência em outros minerais também tem sido mencionado. Muitos dos efeitos específicos do $\mathrm{Al}$ no suprimento e utilização de outros minerais vem sendo revisados (BROWN et al., 1972; FOY, 1974). O crescimento vegetal é normalmente reduzido na presença do $\mathrm{Al}$, no entanto, efeitos benéficos de baixas concentrações de $\mathrm{Al}$ tem sido reportados (GRIME \& HODGSON, 1969; ANDREW et al., 1973). O crescimento vegetal é reduzido quando minerais essenciais se tornam limitados ou estão em excesso, e deficiência de tais minerais inibem o crescimento aéreo mais que o radicular ou vice-versa, CLARK 1970.

SANTANA et al. (1973), em experimentos com cacau, usando a técnica de raízes subdivididas e posterior análise dos tecidos, observaram a 
translocação da solução das raízes que estavam imersas em solução contendo só $\mathrm{Al}^{3+}$, para as que estavam imersas na solução nutritiva. Concluíram também, que à medida que aumentaram as doses de $\mathrm{Al}^{3+}$ na solução, houve reduções nos conteúdos de $\mathrm{P}$ e Ca na parte aérea. Por outro lado, observaram um acúmulo de $\mathrm{P}$ nas raízes que receberam doses elevadas de alumínio. CAMARGO et al. (1984) observaram uma diminuição nas concentrações de potássio, cálcio e magnésio no tecido foliar de plantas de arroz devido ao aumento do teor de alumínio no substrato nutritivo.

Em milho, a análise química de frações de dois cultivares, cultivados em meio líquido, contendo $\mathrm{Al}$, mostrou que o metal interfere no suprimento de $\mathrm{Ca}$ e $\mathrm{Mg}$ e no transporte de $\mathrm{P}$ e $\mathrm{K}$. O transporte de $\mathrm{P}$ das raízes para os ramos diminui a medida que aumenta a concentração de Al na solução nutritiva. BENNET et al. (1985) concluíram que na falta de $\mathrm{Al}$, ambos os cultivares em estudo responderam aos baixos níveis de $\mathrm{Mg}$, capturando mais $\mathrm{Ca} \mathrm{e}$ $\mathrm{K}$, sem afetar a produção.

\subsubsection{Nitrogênio}

O nível de toxidez de alumínio está ligado ao grau de absorção de nitrato, portanto, espera-se que, com o aumento parcial no teor de nitrogênio sob a forma nítrica, em certos casos, se possa diminuir o nível de alumínio tóxico McLEAN \& GILBERT, 1927. As modificações no $\mathrm{pH}$ do meio são determinadas pela absorção diferencial de cátions e de ânions e, portanto, dependem do suprimento relativo de nitrato $\left(\mathrm{NO}_{3}^{-}\right)$e de amônio $\left(\mathrm{NH}_{4}^{+}\right)$. Quando o nitrogênio é fornecido na forma de amônio, as plantas tendem a acidificar o meio, enquanto que a forma de nitrato resulta em um aumento no $\mathrm{pH}$.

A tolerância ao alumínio parece estar relacionada com a capacidade diferencial de certas plantas, principalmente trigo, modificarem o $\mathrm{pH}$ do meio onde se desenvolvem (CAMBRAIA, 1989).

FOY \& FLEMING (1982) demonstraram que o genótipo de trigo tolerante a níveis tóxicos de alumínio, promoveu um aumento maior no $\mathrm{pH}$ das soluções nutritivas e apresentou maior atividade da redutase do nitrato que o genótipo sensível ao alumínio. Concluíram que o cultivar, por ser mais eficiente na absorção de $\mathrm{NO}_{3}{ }^{-}$, devido à sua alta atividade da redutase do nitrato, foi capaz 
de manter um $\mathrm{pH}$ mais elevado na região próxima ao sistema radicular, manifestando assim uma maior tolerância ao alumínio.

Evidências recentes indicam que as plantas tolerantes são capazes de absorver o $\mathrm{NO}_{3}^{-}$mais rapidamente que o $\mathrm{NH}_{4}{ }^{+}$. Para FLEMING \& FOY (1983), plantas tolerantes seriam aquelas capazes de elevar o $\mathrm{pH}$ do meio mais rapidamente, provocando a precipitação do alumínio, ficando expostas a menores concentrações de alumínio solúvel e, portanto, sujeitas a efeitos menos intensos desse elemento.

Alguns cultivares tolerantes de trigo, cevada, arroz, ervilha e milho não híbrido, promovem o aumento do $\mathrm{pH}$ da solução nutritiva e assim diminuem a solubilidade e a toxicidade do alumínio por precipitação (FOY et al., 1978). Esse fato poderia ser atribuído à maior absorção de nitratos, em detrimentos do amônio (FOY \& FLEMING, 1978). A absorção preferencial do $\mathrm{NH}_{4}{ }^{+} / \mathrm{NO}_{3}{ }^{-}$parece estar envolvida no comportamento diferencial de genótipos com relação à tolerância a alumínio. A ocorrência de efeitos negativos do alumínio na absorção de $-\mathrm{NO}_{3}$ - é uma indicação da inibição pelo alumínio na absorção de ânions. Parece não haver dúvida de que o alumínio age diretamente sobre a enzima redutase do nitrato, envolvida na absorção e na redução do $\mathrm{NO}_{3}^{-}$(LEE, 1971).

A ausência de redução na atividade da enzima Redutase de Nitrato em raizes pode ser devido ao suprimento direto de $-\mathrm{NO}_{3}^{-}$em nível adequado à atividade enzimática. Com relação às enzimas responsáveis pela incorporação de $\mathrm{N}$ reduzido em compostos orgânicos, PIMENTA et al. (1987) mostraram que o alumínio parece não afetar diretamente as atividades das enzimas sintetase da glutamina (GS), sintetase do glutamato (GOGAT) e de glutamato oxaloacetato transaminase (GOT).

O alumínio também exerce efeitos na fixação biológica do nitrogênio, afetando a infecção, a iniciação e o crescimento de nódulos e a atividade da nitrogenase. $O$ estresse do alumínio pode interferir na fixação biológica do nitrogênio através de: a) efeitos negativos diretamente na planta hospedeira; b) reduções na sobrevivência de rizóbios; c) interferência nos vários estádios dos processos de nodulação e fixação do nitrogênio (FOY, 1988).

Segundo CAMBRAIA (1989), o alumínio também interfere com várias enzimas relacionadas com a assimilação do nitrogênio, e provavelmente com o catabolismo de aminoácidos, proteínas e outros compostos nitrogenados, 
também aumenta a viscosidade do protoplasma (FOY, 1974), interfere na absorção, no transporte e na utilização de vários nutrientes minerais (LANCE \& PEARSON, 1969), fazendo inclusive, crescer a porcentagem de - $\mathrm{NO}_{3}$ - enquanto o teor de aminoácidos aumenta, sugerindo um efeito do alumínio sobre a absorção do nitrogênio e também sobre a degradação de proteínas.

\subsubsection{Fósforo}

A toxidez causada pelo $\mathrm{Al}$ tem sido associada a um grande número de desordem nutricional em plantas estressadas em altas concentrações de $\mathrm{Al}$, principalmente em se tratando do P (WRIGHT, 1943; FOY \& BROWN, 1963: ANDREW \& BERG, 1973), Ca (FOY,et al., 1972; FOY, 1974), Mg e Mn (CLARK, 1977; GRIMME, 1982). Tentativas de equiparar a deficiência nutricional com a expressão fisiológica da toxidez pelo Al vem sendo freqüentes (WRIGHT, 1943; FOY \& BROWN, 1963; FOY, et al., 1978) e a demonstração da habilidade diferenciada em adquirir nutrientes na presença do Al vem sendo interpretada como diferenças em função das variedades vegetais frente ao $\mathrm{Al}$ (FOY et al., 1972; CLARK, 1977; KRIZEK \& FOY, 1982).

Vários autores (WALLIHAN, 1948; CLARKSON, 1965; CLARKSON, 1969) tem questionado o conceito que interações entre Al e P envolvendo a precipitação de fosfato de $\mathrm{Al}$ em raízes de plantas representam as respostas primárias à presença de $\mathrm{Al}$, além de existirem fortes indícios que os sítios de suprimento para o $\mathrm{Al}$ e o $\mathrm{P}$, sequer coincidem. Tentativas de explicar o efeito do $\mathrm{Al}$ no suprimento de cátions são pouco freqüentes (CLARKSON \& SANDERSON, 1971).

Um grande número de trabalhos publicados mostram que os sintomas visíveis da toxidez de alumínio na parte aérea relembram aqueles da deficiência de fósforo e que o suprimento de $\mathrm{P}$ ao substrato de crescimento ocasiona um efeito de proteção contra a injúria do $\mathrm{Al}^{3+}$ (FURLANI, 1989). Este fato levou muitos pesquisadores a atribuir aos efeitos da fitotoxidez do alumínio a uma deficiência de fósforo, induzida pelo alumínio (FOY, 1988).

Em algumas espécies, alguns sintomas de toxicidade de $\mathrm{Al}^{3+}$ são similares aos de uma severa deficiência de P (FOY \& BROWN, 1964; FURLANI \& CLARK, 1981). O padrão típico da distribuição de $\mathrm{P}$ em plantas estressadas por 
$\mathrm{Al}^{3+}$ revela o acúmulo nas raízes e a diminuição em órgãos da parte aérea. Esses resultados levaram CLARKSON (1966a) a visualizar, em plantas estressadas por alumínio, uma reação de contínua absorção - precipitação, que reduzia a entrada de $\mathrm{P}$ nas raízes e seu subseqüente transporte para a parte aérea. Há também a possibilidade de ocorrer alguma reação de adsorção ou de precipitação do $\mathrm{P}$ da solução com o alumínio das raízes (WRIGHT \& DONAHUE, 1953; RORISON, 1965; CLARKSON, 1966 a; CALBO, 1978).

WRITH (1943) refere-se à precipitação do $\mathrm{P}$ pelo $\mathrm{Al}^{3+}$ dentro da planta e conseqüentemente à redução da disponibilidade do $\mathrm{P}$ para os processos metabólicos. O alumínio interfere no bom funcionamento dos metabólitos fosforilados, inibe a enzima hexoquinase, interfere na produção de DNA e diminui a incorporação do P inorgânico em RNA (CLARKSON, 1966 b; 1969).

RORISON (1965) verificou que a esterificação de fosfato inorgânico nos nucleotídeos foi diminuída pelo alumínio nas raízes. A fosforilação dos açúcares foi diminuída também, mas não tanto quanto nos nucleotídeos.

RANDALL \& VOSE (1963) afirmaram que o aumento na taxa de absorção de $\mathrm{P}$ acontecia pelo estímulo do alumínio na redução do citocromo. Porém, logo após a absorção do $\mathrm{P}$, este se ligaria ao $\mathrm{Al}^{3+}$ na planta, o que poderia causar sua deficiência na parte aérea. Esses mesmos autores, trabalhando com $P$ marcado, encontraram que o principal efeito da toxicidade de alumínio nas plantas resultava da redução drástica na assimilação de fósforo.

A deficiência de $P$ está relacionada com a sua precipitação, na forma de fosfato de alumínio no espaço livre aparente (ELA), ocasionando uma redução na absorção do $\mathrm{P}$. A fim de evitar o contato $\mathrm{Al}$ - $\mathrm{P}$, realizaram-se vários trabalhos com plantas, pelo sistema de raízes divididas e verificou-se através de análises das partes da planta, a formação de fosfatos de alumínio, com reflexos negativos sobre o desenvolvimento das mesmas (WRITH, 1943), o que leva a crer que o metabolismo foi alterado.

Dentro das células esta interação $\mathrm{P} \times \mathrm{Al}$ continua, passando a interferir no metabolismo de açúcares (CLARKSON, 1966b), nucleotídeos e ácidos nucleicos, inclusive DNA (MATSUMOTO et al., 1976). A inibição da divisão celular das raízes e a redução do translocamento do $\mathrm{P}$ para as partes aéreas 
são duas formas com as quais $\mathrm{o} \mathrm{Al}^{3+}$ afeta o crescimento das plantas (CLARKSON, 1966 a).

O exame microscópio de plantas cultivadas em condições de toxidez de alumínio mostra um grande número de células com dois núcleos na região meristemática das pontas das raízes, indicando inibição da divisão celular devido à deficiência de fósforo (RIOS \& PEARSON, 1964).

Sob condições de baixos teores de oxigênio, a toxidez de $\mathrm{Al}^{3+}$ manifesta-se como uma queda nos níveis de nucleotídeos, inclusive os adenosina trifosfato (ATP). Posteriormente, o $\mathrm{Al}^{3+}$ forma complexos com ATP e inibe as ATPases (CALBO \& CAMBRAIA, 1980a) e outras fosfatases da membrana plasmática, dificultando ou impedindo a utilização dessa forma de energia pelas células (FURLANI, 1983).

\subsubsection{Potássio}

Estudos conduzidos por SWHAYDA \& HAUG (1986) com membranas de raízes de milho, revelaram que os iônicos $\mathrm{Al}^{3+} \mathrm{e} \mathrm{Ca}^{2+}$ ocasionam rigidez nos lipídeos da membrana, possivelmente por ligações aos grupamentos fosfolipídicos negativamente carregados. Desde que a força de ligação do cátion aos fosfolipídeos parece ser proporcional à carga do íon, o Al liga-se à membrana mais fortemente que o Ca. Esse efeito ocasiona alterações na permeabilidade da membrana e pode promover o fluxo de íons, principalmente de potássio (TAYLOR, 1988a).

Em plantas de arroz, o alumínio compete com o $\mathrm{K}$ pelos sítios de absorção na raiz, diminuindo a absorção do nutriente, com conseqüente redução no teor de $\mathrm{K}$ das raízes e da parte aérea das plantas (ALAM, 1983).

$\mathrm{O}$ aumento nos teores do alumínio no substrato promoveu a diminuição das concentrações de $\mathrm{K}$ na parte aérea das plantas de aveia (ALAM \& ADAMS, 1979 b) e também nas raízes (WAGATSUMA \& EZOE, 1985).

\subsubsection{Cálcio}

Níveis tóxicos de alumínio geralmente induzem as deficiências ou sintomas de deficiência de cálcio (CAMBRAIA, 1989). A absorção de 
quantidades reduzidas de $\mathrm{Ca}^{2+}$ é, em geral, observada em plantas com injurias causadas pelo alumínio (CLARKSON \& SANDERSON, 1971). As adições de $\mathrm{Ca}^{2+}$ e $\mathrm{Mg}^{2+}$ aos substratos contendo o $\mathrm{Al}^{3+}$ podem reduzir os efeitos inibitórios do alumínio sobre o crescimento de raízes (KINRAIDE \& PARKER, 1987 b).

Em algumas espécies, alguns sintomas de toxicidade de $\mathrm{Al}^{3+}$ são semelhantes aos de deficiência de $\mathrm{Ca}^{2+}$, particularmente os relativos ao crescimento radicular (HALLSWORTH et al., 1957), podendo ocorrer a formação de folhas recurvadas e o colapso do pecíolo, como é freqüentemente observado em soja (ARMINGER et al., 1968). Em aveia, OTSUKA (1968) e ALAM \& ADAMS (1979 b) encontraram teor menor de $\mathrm{Ca}^{2+}$ na parte aérea, em função do aumento da concentração de $\mathrm{Al}^{3+}$ na solução. Em trigo e cevada resultados semelhantes foram encontrados (OTSUKA, 1968).

A presença de $\mathrm{Al}^{3+}$ no meio de cultivo afeta o desenvolvimento das plantas e reduz o crescimento radicular em muitas espécies (FLEMING \& FOY, 1983 e SILVA, 1983); em outras, há redução do comprimento, sem que o peso do sistema radicular seja afetado (MOSQUIN, 1978).

De acordo com SIEGEL \& HAUG (1983), o $\mathrm{Al}^{3+}$ interfere com a atividade da enzima ATPase estimulada pela calmodulina (Cam). A calmodulina existe na forma de um polipeptídeo monomérico com quatro sítios de ligação para $\mathrm{Ca}^{2+}$, o qual parece agir como segundo mensageiro de um sistema regulatório de vários processos metabólicos importantes. $\mathrm{O} \mathrm{Al}^{3+}$ ao se ligar à calmodulina provoca mudanças de conformação nessa proteína, alterando sua interação com certas enzimas e proteínas, tais como fosfolipases, quinase do NAD, adenilciclase e $\mathrm{Ca}^{2+}$-ATP ases (CAMBRAIA, 1989).

A afinidade do $\mathrm{Al}^{3+}$ com a Cam é cerca de 2,5 a 10 vezes maior que a do $\mathrm{Ca}^{2+}$ e produz uma conformação diferente, que inativa a proteína e previne os seus efeitos estimulantes nas atividades enzimáticas dependentes. Assim sendo, uma das hipóteses plausíveis dos efeitos fitotóxicos do $\mathrm{Al}^{3+}$ estaria relacionada com a inibição na atividade da proteína calmodulina (SIEGEL \& HAUG, 1983). Essa hipótese é fundamentada pelas observações: a) a toxidez de $\mathrm{Al}^{3+}$ parece imitar a deficiência de $\left.\mathrm{Ca}^{2+} ; b\right)$ a absorção pelas raizes parece ocorrer de forma trocável nos pontos de ligação do $\mathrm{Ca}^{2+}$; c) altas concentrações de $\mathrm{Ca}^{2+}$ podem parcialmente aliviar a toxidez de $\mathrm{Al}^{3+}$, sendo os efeitos independentes dos ocasionados pelos aumentos na força iônica; d) a calmodulina concentra-se nas 
pontas de raízes onde também ocorre a toxidez de alumínio com a aparente inibição da mitose; e) os antagênicos da calmodulina bloqueiam a divisão celular, possivelmente através de efeitos nas microfilinilas (FURLANI, 1989).

Considerando a importância da Cam para os vários processos regulados pelo $\mathrm{Ca}^{2+}$, admite-se como certa a participação desse sistema no mecanismo de tolerância ao alumínio (CAMBRAIA, 1989). Contudo, trabalhos recentes utilizando a cultura de trigo com tolerância diferencial ao alumínio, não se detectaram diferenças significativas nos níveis de Cam, quando aqueles cultivares foram submetidos a níveis tóxicos de $\mathrm{Al}^{3+}$, colocando em dúvida a hipótese da participação do Cam no mecanismo de toxidez do alumínio (LARKIN, 1987).

$\mathrm{O}$ crescimento inadequado das raizes de plantas em solos ácidos deficientes em $\mathrm{Ca}^{2+} \mathrm{e} \mathrm{Al}^{3+}$ pode ser normalizado pela adição de 0,10 a $1,15 \mathrm{meq}$ de $\mathrm{Ca} / 100 \mathrm{~g}$ de solo na forma de cloreto, fosfato ou carbonato, conforme mostrado por RITCHEY et al. (1983).

Há evidências que, mesmo em solução nutritiva, o sulfato de cálcio diminui o efeito tóxico do alumínio. Isto foi demonstrado por ADAMS \& LUND (1966), para o algodão cultivado em vasos com solo e solução nutritiva em recipiente colocado por baixo.

FOY et al. (1969) mencionaram que a interferência marcante do $\mathrm{Al}^{3+}$ sobre a absorção e o transporte do $\mathrm{Ca}^{2+}$ parece estar altamente relacionada com o grau de sensibilidade das culturas ao alumínio.

Em milho, RHUE \& GROGAN (1977) observaram que o aumento da concentração de $\mathrm{Ca}^{2+}$ diminuiu os danos causados pelo alumínio nas raízes da planta tolerante e não na sensível. Esta diferença foi devida a uma maior resistência aos danos no meristema da raiz do cultivar tolerante. Resultados semelhantes foram encontrados em cevada (HELCHT-BUCHHOLZ \& SCHUSTER, 1987).

\subsubsection{Magnésio}

Reduções na concentração de magnésio das raízes e da parte aérea de plantas estressadas por alumínio, são comumente relatadas na literatura (FURLANI, 1989). SANTANA et al. (1973), trabalhando com plântulas de cacau, 
verificaram que a concentração de $\mathrm{Mg}^{2+}$ parece aumentar na parte aérea e diminuir nas raízes, à medida que se elevam as doses de $\mathrm{Al}^{3+}$. ALAM \& ADAMS (1979b) também encontraram maiores teores de $\mathrm{Mg}^{2+}$ na parte aérea com o aumento da concentração de $\mathrm{Al}^{3+}$ no substrato.

Segundo GRIMME (1983), o alumínio acarreta inibição específica na absorção de $\mathrm{Mg}^{2+}$ pelas raízes. Entretanto, o suprimento de $\mathrm{Mg}^{2+}$ ao meio de crescimento inibe o aparecimento de efeitos tóxicos do $\mathrm{Al}^{3+}$ em plantas. De qualquer maneira, embora a deficiência de $\mathrm{Mg}^{2+}$ não seja a única causa do efeito de injúria do $\mathrm{Al}^{3+}$, a sua ocorrência é parte integrante da síndrome da fitotoxidez de $\mathrm{Al}^{3+}$, uma vez que o funcionamento normal de vários processos metabólicos dependem do $\mathrm{Mg}^{2+}$, direta ou indiretamente.

BATAGLIA et al. (1983), em estudos com cultivares de trigo com tolerância diferencial ao alumínio, puderam observar que o aumento de produtividade nos diversos cultivares em função da calagem foi quase sempre correlacionado positivamente com as concentrações de $\mathrm{Mg}^{2+}$. Para esses autores, parece claro que o $\mathrm{Mg}^{2+}$ é o nutriente mais limitante da produção, uma vez que as maiores produções ocorrem sempre que a deficiência desse nutriente foi eliminada. Verificaram que, para o cultivar mais tolerante à toxicidade de $\mathrm{Al}^{3+}$, a deficiência de $\mathrm{Mg}^{2+}$ afetou mais diretamente a produção, enquanto que para os cultivares sensíveis, além de $\mathrm{Mg}^{2+}$, o acúmulo de $\mathrm{Al}^{3+}$ na parte aérea e a menor absorção de outros nutrientes em função do menor desenvolvimento radicular, pareceram ser os fatores principais da redução do crescimento e produção de grãos nos niveis mais baixos de calagem.

Em plantas de milho, RHUE \& GROGAN (1977) verificaram que em baixas concentrações de $\mathrm{Ca}^{2+}$, o aumento nas concentrações de $\mathrm{Mg}^{2+}$ diminui os danos provocados pelo $\mathrm{Al}^{3+}$ nas raízes, tanto em cultivares tolerantes quanto sensíveis ao alumínio.

\subsection{Efeito do alumínio no milho}

A existência de variabilidade genética entre e dentro de espécies de plantas para a tolerância ou a resistência ao excesso de Al foi descrita para inúmeras espécies vegetais. (FOY et al., 1978; LEFEVER 1981, ), inclusive para o milho, tanto em solução nutritiva (CLARK \& BROWN, 1974; RHUE \& 
GROGAN, 1977; GARCIA JÚNIOR \& SILVA 1979, MAGNAVACA, 1982) como em solo com elevada acidez (BAHIA FILHO et al. 1978).

FURLANI et al. (1986) avaliaram a tolerância ao $\mathrm{Al}(4,5 \mathrm{mg} / \mathrm{l}) \mathrm{de}$ 39 linhagens e 98 materiais comerciais de milho, usando-se a técnica de solução nutritiva. Constataram que baseando-se nos valores do índice de crescimento da radícula (ICR) obtidos para as 39 linhagens, avaliados os materiais que apresentaram reduções inferiores a $35 \%$ no crescimento da raiz foram consideradas tolerantes ao $\mathrm{Al}$ em solução nutritiva. Neste experimento, usaram dois controles IAC HS7777 (sensivel ao Al) e IAC HS1227 (tolerante ao Al). Observaram que as duas linhagens que dão origem ao IAC HS7777 (sensível ao $\mathrm{Al})$, também apresentaram reduções drásticas no crescimento de suas raizes, ao contrário do ocorrido com as duas linhagens componentes do IAC HS1227 (tolerantes ao Al). Concluíram que o comportamento diferencial dos híbridos simples IAC HS1227 e IAC HS7777 parece estar diretamente associado ao comportamento de seus antecedentes. Para os materiais comerciais, os resultados foram baseados nos valores de crescimento líquido da radícula (CLR) e demonstraram a existência de variabilidade de comportamento entre os materiais procedentes de diversas firmas produtoras de semente, assim como entre os materiais de uma mesma sigla, mas nenhum desses materiais apresentou comportamento superior ao da cultivar IAC HS1227. Os resultados referentes à distribuição das progênies $S_{1}$ das populações IAC-Maya e IAC-Taiuba, em função de classes de valores de ICR (IAC-Maya) e CLR (IAC-Taiuba) apresentaram um número relativamente pequeno de progênies que tiveram comportamento semelhante ao do controle tolerante ao Al (IAC HS1227). A população IAC-Maya avaliada apresentou apenas uma progênie $S_{1}$ com relativa tolerância ao Al. Verificaram entretanto, que plantas individuais de algumas das progênies avaliadas, apresentaram-se desprovidas dos sintomas típicos da toxicidade de $\mathrm{Al}$ nas raízes (encurtamento e engrossamento da radícula e ausência de ramificações secundárias finas). Os valores do crescimento líquido da radícula (CLR) avaliados em plantas de 466 progênies $S_{1}$ da população IAC-Taiuba mostraram um quadro semelhante ao apresentado pela população IAC-Maya. Um pequeno número de progênies teve padrão de comportamento semelhante ao controle tolerante IAC HS1227. Da mesma forma que observado para a população IAC-Maya, plantas individuais de algumas progênies $S_{1}$ da população IAC- 
Taiuba também apresentaram crescimento normal em presença de $\mathrm{Al}$ na solução nutritiva.

Os autores concluíram que os métodos de avaliação usados foram eficientes na identificação de materiais de milho tolerante ao Al em solução nutritiva. Constataram também, a ocorrência de ampla variabilidade genética para a tolerância de milho ao $\mathrm{Al}$.

LOPES et al. (1987) avaliaram populações de milho, bem como seus cruzamentos, quanto à tolerância ao alumínio em solução nutritiva. Observaram que a porcentagem de crescimento relativo da raiz seminal conseguiu separar materiais tolerantes daqueles não tolerantes. No entanto, o peso de material seco da parte aérea e do sistema radicular foram pouco eficientes para esse fim. Os autores concluíram que o carater tolerância à toxidez de $\mathrm{Al}$ não revelou grau de herança citoplasmática. As populações $\mathrm{CMS}_{30}$ e $\mathrm{CMS}_{36}$ foram as indicadas como fontes de tolerância ao alumínio.

PRIOLI et al. (1985), utilizando a variedade de milho "Composto Dente", obtiveram três ciclos de seleção $\left(\mathrm{C}_{0}, \mathrm{C}_{1}\right.$ e $\left.\mathrm{C}_{2}\right)$ para tolerância à toxidez do $\mathrm{Al}$, em solução nutritiva com excesso de $\mathrm{Al}$, usando-se a metodologia e a solução nutritiva proposta por RHUE \& GROGAN (1976). A concentração de Al na solução correspondeu a $6,75 \mathrm{ppm}$ e o pH foi ajustado para 4,6 diariamente. Após 12 dias da germinação, efetuou-se a avaliação da tolerância das plantas à toxidez de $\mathrm{Al}$, com base nos seguintes caracteres: a) comprimento da planta: b) comprimento da rádicula; c) comprimento da maior raiz nodal; d) número de raízes nodais; e) clorose nas folhas.

Os autores observaram que para as medidas de comprimento da radícula e da raiz nodal e para o número de raízes nodais houve um acréscimo de médias à medida que se efetuava a seleção. Isso se refletiu nos ganhos genéticos obtidos para os mesmos caracteres, os quais foram positivos, indicando algum efeito da seleção. Os resultados referentes aos ganhos genéticos obtidos e as análises de variância praticamente não diferiram nos dois tipos de delineamento. Isso evidencia que as plantas selecionadas, aparentemente tolerantes, não modificaram diferencialmente o $\mathrm{pH}$ da solução nutritiva, em comparação com a população original. Esse comportamento já era esperado no decorrer do experimento e portanto, foram feitas correções diárias de $\mathrm{pH}$, para minimizar a precipitação do $\mathrm{Al}$ da solução. 
Assim, se a tolerância fosse proporcionada apenas pela capacidade de elevação do $\mathrm{pH}$ da solução, não seria possível a identificação e a seleção de plantas tolerantes em experimento dessa natureza, porque qualquer elevação de $\mathrm{pH}$ por parte de genótipos tolerantes seria anulada pelas correções diárias. Portanto, apenas plantas tolerantes pelo mecanismo da desentoxicação do $\mathrm{Al}$ absorvido poderiam ser identificadas e selecionadas. Isso parece ter sido confirmado, pelos resultados dos testes de coloração com hematoxilina, conforme foi proposto por POLLE et al., (1978) e modificada por FONSECA Jr. et al., (1981), testes que mostraram que as plantas de todos os ciclos absorveram igualmente o alumínio da solução. Concluíram então que os resultados das análises de variância, nos experimentos de avaliação dos ciclos em solução nutritiva, evidenciam a influência da seleção para tolerância à toxidez de Al sobre o comprimento da planta, comprimento da radícula e comprimento da raiz nodal, mas não sobre o número de raízes nodais. Nos dois experimentos, o ciclo $\mathrm{C}_{2}$ não diferiu significativamente do Ciclo $\mathrm{C}_{3}$, para os três primeros caracteres mencionados. Isso indica que a seleção não progrediu após o segundo ciclo de seleção. Embora não se possa, com base nesses dados, formular uma explicação sólida para esse fato, pode-se sugerir a possibilidade de estar a tolerância à toxidez de alumínio no germoplasma utilizado, próxima ao limite de seleção. Isso ocorreria se a tolerância fosse condicionada por um gene dominante, conforme trabalho de RHWE et al., (1978). A seleção aproximaria a tolerância rapidamente desse limite, de modo que os dois ciclos seguintes poderiam não diferir muito. Por outro lado, GALVÃO \& SILVA (1978) trataram a tolerância como caráter quantitativo.

Foram determinados os níveis de $\mathrm{Al}$ em cada bloco, nos dois experimentos no campo, verificando-se grande variação dentro de cada experimento, mas quase nenhuma diferença entre experimentos. Concluíram que houve efeito da seleção apenas para altura da planta, altura da espiga, número de plantas acamadas e número de folhas acima da espiga. $\mathrm{O}$ nível de $\mathrm{Al}$ influenciou negativamente esses caracteres apenas na população $C_{0}$, que não sofreu seleção para tolerância. As populações $\mathrm{C}_{1}$ e $\mathrm{C}_{2}$, resultantes de seleção, não foram influenciadas pelo nivel de $\mathrm{Al}$.

FURLANI \& HANNA (1984) pesquisaram as diferenças de comportamento de oito cultivares de arroz e sete de milho para a tolerância ao $\mathrm{Al}$. 
Os níveis de Al usados na avaliação de plantas de arroz e de milho foram escolhidos a partir de ensaios envolvendo concentrações de $\mathrm{Al}(0,10,20$ e 40 mg.L $\mathbf{~}^{-1}$ para arroz e $0,0,3,0,4,5$ e $6,0 \mathrm{mg.L}-1$ para milho). O sistema para a avaliação de genótipos de arroz utilizou solução nutritiva contendo em miligramas por litro: $\mathrm{Ca}-30, \mathrm{~K}-18, \mathrm{Mg}-3,8, \mathrm{~N}_{-} \mathrm{NO}_{3}-31, \mathrm{~N}^{-\mathrm{NH}_{4}}$ - 4, P - 0,2, B - 0,05, Fe $-0,5, \mathrm{Mn}-0,1, \mathrm{Mo}-0,02, \mathrm{Zn}-0,03, \mathrm{Cu}-0,01$ e $\mathrm{Al}-20$, e os cultivares padrões de resposta diferencial IAC 25 (tolerante) e IAC 899 (sensível). Para o milho, o sistema utilizava solução nutritiva contendo o quíntuplo das concentrações de macronutrientes, a mesma concentração de micronutrientes e 4,5 mg de Al.L-1, e os cultivares de comportamento diferencial HS1227 (tolerante) e HS7777 (sensível) usados como controles. Segundo os autores, os resultados indicaram a possibilidade de selecionar precocemente cultivares de arroz e de milho para a adaptação a solos com problemas de toxicidade de $\mathrm{Al}$, mediante técnicas de solução nutritiva em apoio aos programas de melhoramento genético. É evidente que as técnicas de laboratório não substituem os trabalhos de seleção em campo, mas podem atuar como método pré-seletivo de materiais genéticos que tenham possibilidade de sobrevivência em condições de solo com estresse de $\mathrm{Al}$.

WAGATSUMA \& AKIBA (1989), estudando genótipos de aveia, arroz, cevada, ervilha e milho, que diferem quanto à tolerância ao alumínio, sugeriram que a existência de uma menor negatividade da superfície da plasmalema das células radiculares podia determinar uma menor ligação com o alumínio, conferindo uma maior tolerância ao elemento. Segundo CLARK (1975), cultivares tolerantes de milho apresentaram maiores atividades de fosfatase nas raízes do que os genótipos sensíveis da mesma espécie.

WAGATSUMA et al. (1988), investigando a relação entre a tolerância ao $\mathrm{Al}$ e a capacidade "suporte" da plasmalema radicular pelo $\mathrm{Al}$, embeberam seç̧ões radiculares com azul de metileno e a intensidade da cor azul no protoplasto foi medida através de um analisador de gráficos, conectado a um computador. $\mathrm{O}$ azul de metileno marcou tanto a parede celular quanto o protoplasto. Secções de raízes mortas em água fervente também estavam marcadas com a mesma intensidade de azul que as secções radiculares vivas. Os autores concluiram que a tolerância do milho ao $\mathrm{Al}$ estava correlacionada com a negatividade elétrica do protoplasto da parte mais externa do córtex, como foi determinado com o azul de metileno. A negatividade elétrica da plasmalema, 
especialmente nos ponteiros e partes mais externas da raiz, pode determinar faixas de tolerância ao $\mathrm{Al}$ entre as várias espécies de plantas.

Segundo CAMBRAIA (1989), as plantas tolerantes seriam aquelas que fossem capazes de absorver mais ou utilizar mais eficientemente o fósforo. Diversos trabalhos têm demonstrado que a aplicação de $\mathrm{P}$, de modo a entrar em contato com o maior volume de raízes possível, é condição para se ter maior absorção desse nutriente e maior crescimento do milho. (KAMPRATH, 1967; JUNGK \& BARBER, 1974; ANGHINONI \& BARBER, 1980; STRYKER et al., 1974).

Os estudos da interação $\mathrm{P} \times \mathrm{Al}$ sugerem que a tolerância ao $\mathrm{Al}$ confere à planta uma característica de maior capacidade de absorver fósforo. Além disso, a variabilidade genética dessas características, juntamente com a tolerância à seca, parecem ser abundantes no milho, indicando que esses fatores devem ser considerados na análise para a identificação do mecanismo que os condiciona.

BEAR (1964) citou as plantas que crescem bem em condições ácidas de solo, indicando tolerância a essas condições. Entre elas estão: aveia, batata, azaléia, algodão e milho que são moderadamente tolerantes, enquanto alfafa, beterraba e aspargos são sensíveis.

OLMOS \& CAMARGO (1976), avaliando o grau de toxidez do Al para cada cultura, concluíram que, com exceção das plantas mais tolerantes à acidez (chá-da-india, erva-mate e mandioca), existe um valor limite acima do qual as plantas não se desenvolvem mais. Estabeleceram também os limites críticos aproximados desse valor, para os solos do Rio Grande do Sul.

Em solução nutritiva, a concentração tóxica de alumínio, constatada por McLEAN \& GILBERT (1927) foi de $2 \mathrm{mg} . \mathrm{L}^{-1}$ para a cevada, $7 \mathrm{mg} . \mathrm{L}^{-1}$ para aveia branca, centeio e sorgo enquanto para o milho foi de $14 \mathrm{mg} . \mathrm{L}^{-1}$, o que mostra certa tolerância desta cultura ao alumínio.

FARINA et al. (1980) cultivaram plantas de milho em casa-devegetação utilizando solos contendo altos níveis de Al. Os solos foram calcariados em vários níveis, de forma a apresentarem valores próximos ou acima da neutralidade. Em todos os solos houve uma resposta positiva à calagem, para valores baixos de $\mathrm{pH}$, enquanto que, para dois deles, a produção diminuiu significativamente à medida que o $\mathrm{pH}$ se aproximou da neutralidade. Os autores 
concluíram que o mecanismo através do qual o $\mathrm{Al}$ se torna mais disponível para a planta, à medida que o $\mathrm{pH}$ se aproximava da neutralidade ainda não está claro, e precisa de mais investigação.

MALLETT et al. (1985) observaram que o $\mathrm{pH}$ baixo e a conseqüente toxicidade por $\mathrm{Al}$ são os principais fatores limitantes para a penetração da raiz do milho e sua posterior granação, em muitas partes da África do Sul. Desenvolveram um método baseado em fatores climáticos e em fatores físicos do solo, prevendo a profundidade mais econômica para a incorporação do calcário, através da análise dos períodos chuvosos e dos períodos de seca. Concluíram que se a incorporação do calcário fosse feita no mínimo a $55 \mathrm{~cm}$ de profundidade estaria assegurado que a cultura passasse pelo período de seca da região, sem sofrer efeitos da toxicidade do Al por falta de chuva.

SETIJONO \& SOEPARDI (1985) constataram que a profundidade de incorporação do calcário interferia enormemente nas respostas das plantas de milho à toxidez provocada pelo $\mathrm{Al}$. Observaram que quanto mais profundo aplicar o calcário, maior será a resposta das plantas de milho com relação à produção.

Raizes de plantas de milho e soja foram expostas ao $\mathrm{Al}$ durante um período teste. A composição da solução nutritiva foi aproximadamente a mesma $\mathrm{e}$ todas as espécies e cultivares foram cultivados no mesmo tanque por um período de tempo comum. Sabendo-se que o $\mathrm{Al}$ em solução tem um rápido efeito adverso na elongação celular, principalmente no ápice radicular (CLARKSON, 1965; FOY, 1984), o primeiro efeito notado da toxidez de $\mathrm{Al}$ é a redução no crescimento radicular. Então, crescimento ou elongação da raiz principal é sempre usado como índice vegetal para a tolerância ou suscetibilidade à toxidez por $\mathrm{Al}$ (MENDES et al., 1984). HETHERINGTON et al. (1988) constataram que o comprimento da raiz principal, tanto de espécies quanto de cultivares, diminuia com o aumento do Al.

O Al é conhecido como aquele elemento que reduz a gama de respostas radiculares (CLARKSON,1965; BENNET, et al., 1985) e é bem possível que as alterações na composição química das plantas, em função do $\mathrm{Al}$, tenham início em modificações fisiológicas da raiz.

WAGATSUMA et al. (1987), em observação microscópica, revelaram que o $\mathrm{Al}$ induz várias mudanças morfológicas na superfície das raízes e diminui a turgescência das células epidérmicas do ápice radicular e das raízes de 
elongação, destrói as células da epiderme e aquelas células mais externa do cortex das regiões do ápice radicular e de elongação, embora pouca modificação morfológica ocorra nas partes mais próximas da raiz. Testes de marcação nas regiões de elongação, depois de as raízes tratadas com $\mathrm{Al}$, mostraram que a epiderme é a região mais externa do cortex são aquelas mais sensíveis em plantas de milho. O efeito tóxico do $\mathrm{Al}$ já é conhecido, ocorre na elongação das raízes afirmaram os autores, e acrescentaram que esta inibição se inicia no ápice da raiz primária, seguindo para o ápice das raízes secundárias, depois terciárias e assim por diante, até que o sistema radicular se assemelhe a uma esfera de arame farpado.

À medida que apreciáveis quantidades de $\mathrm{Al}$ são absorvidas pela raiz, o $\mathrm{Al}$ é encaminhado ao núcleo celular da raiz e para o $\mathrm{P}$ nas fitas de DNA, resultando na diminuição ou inibição total da divisão celular.

TAN \& BINGER (1986) conduziram experimentos em estufas para avaliar o efeito dos ácidos húmicos em sementes de milho cultivadas em areia, recebendo de 0 a 50 mg.kg-1 de $\mathrm{Al}$ e de 0 a 350 mg.kg-1 de ácidos húmicos. A fertilização foi suprida na forma da solução de HOAGLAND \& ARNON (1950), ajustada para o $\mathrm{pH} 4,8$. Na falta dessa solução, quantidades crescentes de $\mathrm{Al}$ diminuiram claramente a produção de material seco. Plantas tratadas com o nível mais alto de $\mathrm{Al}$ desenvolveram sintomas de toxicidade por $\mathrm{Al}$ retratadas como cloroses marginais e necrose. A adição da solução de Hoagland-Arnon aos vasos que continham $\mathrm{Al}$ fez com que a produção de matéria seca aumentasse de 32,5\% para $42,5 \%$, com as plantas aparentando-se verdes e saudáveis. Os efeitos benéficos da solução também foram sentidos no conteúdo de $\mathrm{Al}$ e $\mathrm{P}$ das folhas de milho. A concentração de $\mathrm{Al}$ nas folhas aumentou linearmente com o aumento do Al no tratamento, com 0 de solução de Hoagland-Arnon, mas diminuiu de 86,6 mg-g-1 com 50 unidades de $\mathrm{Al}$ e 0 de solução de Hoagland-Arnon para 60,5 e 57,4 mg.g-1 com 100 e 350 unidades da solução Hoagland-Arnon, respectivamente. $\mathrm{O}$ aumento do conteúdo de $\mathrm{Al}$ nas folhas como resultado do estress provocado pelo $\mathrm{Al}$, coincidiu com a queda do conteúdo do $\mathrm{P}$ nas folhas. No entanto, a adição da solução de Hoagland-Arnon suprimiu a redução da concentração de $\mathrm{P}$ nas folhas. Nos tratamentos com Al-50 as plantas que receberam a solução de Hoagland-Arnon continham mais $\mathrm{P}$ do que aquelas que receberam 0 da solução. Indicações sugerem que altas quantidades de $\mathrm{Al}$ em 
solução reagem com o P para formar fosfatos de alumínio insolúvel. Entretanto, a presença da solução de Hoagland-Arnon deve cancelar muito do $\mathrm{Al}$, tornando-o inativo para reagir com o P. BINGER (1980) não detectou sintomas de fitotoxicidade em plantas de milho, causados pela presença do alumínio em níveis de 20 a 50 ppm quando na presença de ácidos húmicos.

Segundo SUHAYDA (1987), mudanças induzidas pelo Al na conformação, estrutura e função da membrana plasmática das raizes de milho podem ser combatidas com o ácido cítrico e o málico. Isso resultaria numa diminuição da toxicidade pelo $\mathrm{Al}$ nos tecidos radiculares do milho.

BENNET et al. (1985) investigaram as mudanças ocorridas na região primária de crescimento das raízes de milho, quando tratadas com o $\mathrm{Al}$. Verificaram que as modificações, em detrimento da presença do $\mathrm{Al}$, ocorrem desde as primeiras horas. Modificações das quais faz parte a alteração do núcleo das células do meristema, envolvendo um certo grau de condensação da cromatina indicando um grau de senescência.

MARQUEZINI et al. (1990) descreveram a técnica espectroscópica da "célula fotoacústica aberta" (OCPA: Open-cell photoacustic) como aquela que determina geneticamente as diferenças de enraizamento em resposta à ação tóxica do alumínio, por parte de plantas vivas de milho. Foram examinados exemplares tolerantes e suceptíveis de milho. Os autores concluíram que as diferenças no espectro de luz visível da OCPA dos exemplares do ensaio e da testemunha, tanto das linhagens suceptíveis quanto das tolerantes, foram bastante notáveis para as linhagens suceptíveis, mas imperceptíveis para as tolerantes.

CERETTA (1986) conduziu um experimento em solução nutritiva em câmara de crescimento e em casa-de-vegetação, em Porto Alegre, com o objetivo de avaliar a tolerância ao $\mathrm{Al}$ em cultivares de milho. As avaliações foram realizadas 25 dias após a germinação das sementes. Foram testadas seis cultivares na presença e ausência do Al. A concentração real do Al na solução foi de 2,8 ppm. Na média dos cultivares, a presença do $\mathrm{Al}$ na solução resultou num decréscimo de 9;36 e 58\% na massa seca da parte aérea, na superfície da raiz e no comprimento da raiz, respectivamente. Entretanto, pode observar também que, o raio da raiz aumentou em $57 \%$ nas plantas em solução nutritiva com e sem $\mathrm{Al}$, sendo que os cultivares Empasc 152-Oeste e Empasc 151-Condá foram os mais 
tolerantes ao Al. Entre os cultivares híbridos não houve diferença considerável na tolerância ao Al.

SUHAYDA \& HAUG (1986), estudando membranas de raizes de milho, revelaram que os iônios $\mathrm{Al}^{3+} \mathrm{e} \mathrm{Ca}^{2+}$ ocasionaram rigidez aos lipídios da membrana, possivelmente por ligações aos grupamentos fosfolipídicos, negativamente carregados. A força de ligação do cátion aos fosfolipídeos parece ser proporcional à carga do íon. Portanto, o $\mathrm{Al}^{3+}$ liga-se à membrana mais fortemente que o $\mathrm{Ca}^{2+}$. Esse efeito ocasiona alterações na permeabilidade da membrana e pode promover o efluxo de íons, principalmente de potássio (TAYLOR, $1988 \mathrm{a}$ ).

O Al também afeta os carregadores da membrana conforme evidenciado em estudos realizados com membranas extraídas de raizes de milho (MATSUMOTO \& YAMAYA, 1986), nos quais foram observadas inibições competitivas do $\mathrm{Al}$ nas atividades das enzimas $\mathrm{Mg}^{2+}$-ATPase e $\mathrm{Mg}^{2+}$-ATPase estimulada por $\mathrm{K}^{+}$. A inibição das atividades dessas enzimas pode ser explicada de várias maneiras: a) os íons de $\mathrm{Al}$ ligam-se aos lipídeos da membrana (em particular os lipídeos que cercam a proteína enzimática) e dessa forma alteram a enzima pela modificação nas interações lipídeos-proteínas; b) sem a ocorrência da medição de lipídeos, os íons de $\mathrm{Al}$ podem atuar diretamente na proteína enzimática ou proteínas envolvidas na estimulação da enzima conforme ocorre com a atividade da calmodulina- $\mathrm{Ca}^{2+}, \mathrm{Mg}^{2+}$-ATPase em vesículas de membranas plasmática de raizes de cevada (SIEGEL \& HAUG, 1983).

Os exames de raízes de milho em microscópio eletrônico efetuados por RASMUSSEN (1968) demonstraram que o Al foi precipitado na superficie epidérmica, pois a epiderme preveniu o movimento de Al para o cortex e estelo, e a penetração de $\mathrm{Al}$ nesses tecidos ocorreu somente nos pontos de erupção de raízes laterais.

As respostas de linhagens de milho ao $\mathrm{Mg}$ e ao $\mathrm{P}$ foram observadas por CLARK (1975). A linhagem mais eficiente ao $\mathrm{P}$ foi mais tolerante ao $\mathrm{Al}$ e a linhagem mais eficiente ao $\mathrm{Mg}$ também foi mais tolerante ao $\mathrm{Al}$.

Outros estudos mostraram que a distribuição de $\mathrm{Al}$ e $\mathrm{P}$ foi idêntica em raizes de milho, algodão e feijão tratadas com $\mathrm{Al}$, sugerindo a ocorrência de precipitados Al-fosfato na superficie da raiz e dessa forma inibindo 
a entrada do Al para o simplasto e em menor grau para o apospasto (FURLANI, 1989).

Os sintomas de toxidez de $\mathrm{Al}$ em plantas de milho manifestam-se nas folhas e raizes. Nas folhas, assemelham-se à deficiência de fósforo ou cálcio e, nas raízes, ocorrem crescimento reduzido, engrossamento, poucas ramificações e ineficiência na absorção de nutrientes e água (FOY et al., 1978). 


\section{MATERIAL E MÉTODOS}

\subsection{Local e cultivares}

O experimento foi conduzido em casa-de-vegetação no Setor de Nutrição Mineral de Plantas, do Departamento de Química, da Escola Superior de Agricultura "Luiz de Queiroz" (ESALQ), em Piracicaba, SP e foi realizado em duas etapas, sendo que os cultivares estudados, fornecidos pela CARGILL, foram: C125, C135, C425, C525, C701 e C805.

\subsection{Características dos cultivares}

Foram utilizados seis cultivares de milho, todos híbridos provenientes da CARGILL, que apresentavam as seguintes características: $\mathbf{C 1 2 5}$ - híbridos duplo, semidentado e precoce, rústico e com grãos alaranjados, apresentando grande adaptação e tolerância ao alumínio tóxico e as principais moléstias foliares que ocorrem no Brasil, tem boa tolerância à seca e aos veranicos, sendo também residente à ferrugem causada por Puccinia polysora. C135 - hídrico duplo, semidentado de grãos amarelo-alaranjados, de ciclo normal, de porte médio e alto e que se caracteriza por combinar alta produtividade com estabilidade e rusticidade. Apresenta boa tolerância ao alumínio tóxico e tem resistência a moléstia de colmo. $\mathbf{C 4 2 5}$ - híbrido duplo semidentado precoce, de porte mais baixo. Possui folhas eretas e de verde mais escuro. Excelente sanidade geral, excepcional resistência ao acamamento. Muito resistente ao calor, e ao quebramento. tem ampla adaptação e responde bem as melhores adubações e 
possui excelente qualidade e densidade de grãos. C525 - cultivar semiduro de ciclo médio, semidentado, com grãos de cor laranja, ótima sanidade e alta densidade. Apresenta plantas de cor verde escuro e alta resistência às principais moléstias do milho que ocorrem no Brasil, exceto à ferrugem. Combina excelente qualidade de colmo, raiz e grande sanidade de massa verde com alta produtividade. Tem excelente tolerância ao alumínio, apresenta ampla adaptação a diferentes tipos de solo e condições ambientais. C701 - híbrido duplo, semidentado e precoce, com folhas semi-eretas e resistente à ferrugem. Possui a característica "stay-green" e excelente resistência ao acamamento e ao quebramento. Suas espigas são maiores, mais grossas e com grãos de excepcional qualidade. Não apresenta limitações climáticas, podendo ser plantado em todo o Brasil em época normal quanto na safrinha. $\mathbf{C 8 0 5}$ - híbrido triplo de boa sanidade de plantas, espigas, colmos e raízes, com porte baixo e folhas ereta permite o aumento do número de plantas por hectare. Possui excelente "stay-green".

\subsection{Fase experimental}

$\mathrm{Na}$ primeira etapa, estudaram-se os cultivares C425, C701 e C805, sendo que a semeadura ocorreu no mês de janeiro em bandeja contendo areia lavada, e 7 dias após a emergência, as plantas foram transplantadas para caixas de polietileno, com capacidade para $25 \mathrm{~L}$ de solução. Na segunda etapa estudaram-se os cultivares $\mathrm{C} 125, \mathrm{C} 135$ e C525, sendo a semeadura realizada em março e os demais procedimentos executados de forma análoga.

As plantas foram sustentadas sobre a solução por placas de isopor, medindo $45 \times 65 \mathrm{~cm}$ e com $3 \mathrm{~cm}$ de espessura, contendo cada uma 12 furos. Em cada placa foram colocadas 4 plantas de cada um dos três cultivares (C425, C701 e $\mathrm{C} 805$ ou $\mathrm{C} 125, \mathrm{C} 135$ e C525), perfazendo as 12 plantas da bandeja.

Durante o dia, as plantas permaneciam nas caixas com solução contendo os níveis de alumínio $\left(0,10,20,30,40\right.$ e $\left.50 \mathrm{mg} . \mathrm{L}^{-1}\right)$ e no período noturno, elas eram tranferidas para outra caixa contendo solução nutritiva completa (SARRUGE, 1975), mas antes de transferi-las, as raízes eram lavadas com jatos de água destilada, retirando-se o excesso de alumínio, possibilitando assim um relativo desenvolvimento das plantas. 
As soluções com níveis de alumínio foram obtidas a partir de uma solução contendo $1000 \mathrm{mg} . \mathrm{L}^{\mathbf{- 1}}$, preparada a partir de folhas de papel de alumínio dissolvidas em $\mathrm{HCl} 6 \mathrm{~N}$. O pH inicial das soluções de alumínio foi corrigido para 4,5; sendo feito o acompanhamento das variações de $\mathrm{pH}$, através de leituras semanais, corrigindo-se o $\mathrm{pH}$ com solução de hidróxido de sódio $1 \mathrm{~N}$. As soluções que continham alumínio e a solução nutritiva foram arejadas continuamente, utilizando-se bombas para arejamento de aquário.

A distribuição das bandeijas na casa-de-vegetação foi ao acaso, tanto para os cultivares quanto para as dosagens, sendo efetuado o rodízio periódico das mesmas, procurando-se evitar um eventual efeito do local, sobre o desenvolvimento dos cultivares em estudo (incidência luminosa, proximidade de paredes, etc).

\subsection{Colheita e avaliação}

As avaliações foram realizadas, efetuando-se os cortes 30 e 35 dias após a transferência das plantas para a caixa de polietileno, para a primeira e segunda etapas respectivamente. Após o corte, dividiram-se as plantas em três partes: folhas, colmos + bainhas e raízes, que foram secas em estufa com circulação forçada de ar, até obter-se peso constante, determinando-se então a massa do material seco produzido.

O material foi então moido em moinho do tipo Wiley e homogeneizado, sendo as extrações e as análises para determinação dos macronutrientes realizadas segundo a metodologia descrita por SARRUGE \& HAAG (1974). Para a determinação de alumínio no extrato, utilizou-se um espectrômetro de emissão atômica com plasma induzido de argônio da marca JERRELL ASH, modelo 975.

\subsection{Delineamento experimental e análise estatística}

O delineamento experimental foi o de blocos ao acaso, obedecendo ao esquema fatorial com seis níveis de alumínio $(0,10,20,30,40$ e $50 \mathrm{mg.L}-1)$, 
três cultivares de milho (C425, C701 e C805 ou C125, C135 e C525) e quatro repetições.

A análise estatística foi feita utilizando-se um esquema fatorial $6 \times 6$, com seis niveis de alumínio, seis cultivares e quatro repetições, de acordo com a metodologia descrita por GOMES (1981), através do programa estatístico SANEST.

O quadro de análise de variância para estudar o efeito dos níveis de alumínio foi:

Causas de variação Graus de liberdade

Blocos 3

Cultivares (C) 5

Níveis de $\mathrm{Al}(\mathrm{A})$

C*A 25

Resíduo 105

Total 143

O quadro de análise de variância para estudar o efeito nas partes das plantas foi:

\begin{tabular}{lc} 
Causas de variação & Graus de liberdade \\
\hdashline Blocos & 3 \\
Cultivares (C) & 5 \\
Partes das plantas (P) & 2 \\
C*P & 10 \\
Resíduo & 51 \\
\hline
\end{tabular}

Total 71 


\section{RESULTADOS E DISCUSSÃO}

\subsection{Peso do material seco}

A Tabela 1 apresenta o peso do material seco das folhas (g.planta-1) em função dos níveis de alumínio estudados dentro de cada cultivar. Observa-se que os cultivares, embora tenham todos apresentado redução no peso do material seco das folhas com o aumento da concentração de alumínio da solução, apresentaram comportamentos diversos em relação aos níveis de alumínio. Assim, o cultivar C125 não apresentou estatisticamente redução no peso das folhas com até $20 \mathrm{mg} . \mathrm{L}^{-1}$ de alumínio na solução, reduzindo seu peso somente a partir de 30 mg.L-1; os cultivares C525 e C701 não apresentaram redução no peso das folhas até $10 \mathrm{mg} . \mathrm{L}^{-1}$ e enquanto o primeiro apresentava uma queda significativa nos demais níveis, o segundo não apresentou redução significativa de peso nas mesmas condições, como pode ser observado também para o cultivar C805, que a partir de $10 \mathrm{mg} . \mathrm{L}^{\mathbf{- 1}}$ não apresentou redução de peso. Os outros dois cultivares apresentaram reduções progressivas no peso das folhas, em função dos níveis de alumínio da solução.

O comportamento de cada cultivar quanto ao peso do material seco das folhas, em função dos níveis de alumínio aplicados, é apresentado na Figura 1 , onde são representadas as equações de regressões entre o peso do material seco das folhas (g.planta-1) e as doses de alumínio (mg.L $\mathrm{L}^{\mathbf{- 1}}$ ), para os seis cultivares estudados. Todas as regressões representam a redução do peso das folhas em função dos niveis de alumínio, porém os cultivares C525 e C125 apresentaram reduções representadas por equações lineares, enquanto os demais cultivares 
Tabela 1. Peso do material seco das folhas (g.planta ${ }^{-1}$ ) em função dos níveis de alumínio estudados (mg. $\mathrm{L}^{-1}$ ), dentro de cada cultivar (médias de quatro repetições).

\begin{tabular}{|c|c|c|c|c|c|c|c|}
\hline \multirow[t]{2}{*}{ Cultivares } & \multicolumn{6}{|c|}{ Alumínio (mg. $\mathrm{L}^{-1}$ ) } & \multirow[t]{2}{*}{ Médias } \\
\hline & 0 & 10 & 20 & 30 & 40 & 50 & \\
\hline 525 & $9,97 \mathrm{ABa}$ & $11,85 \mathrm{Aa}$ & $5,55 \mathrm{ABb}$ & $5,13 \mathrm{Abc}$ & 3,07 ABcd & $1,70 \mathrm{Bd}$ & $6,21 \mathrm{~A}$ \\
\hline 135 & $11,75 \mathrm{Aa}$ & $8,30 \mathrm{Bb}$ & $5,70 \mathrm{ABc}$ & $3,50 \mathrm{Acd}$ & $2,85 \mathrm{ABd}$ & $2,15 \mathrm{ABd}$ & $5,71 \mathrm{AB}$ \\
\hline 125 & $7,87 \mathrm{BCa}$ & $7,10 \mathrm{BCa}$ & $7,75 \mathrm{Aa}$ & $4,20 \mathrm{Ab}$ & $2,70 \mathrm{Bb}$ & $2,45 \mathrm{ABb}$ & $5,35 \mathrm{AB}$ \\
\hline 805 & $11,23 \mathrm{Aa}$ & $6,15 \mathrm{BCb}$ & $5,73 \mathrm{ABb}$ & $5,47 \mathrm{Ab}$ & $5,13 \mathrm{Ab}$ & $4,07 \mathrm{Ab}$ & $6,29 \mathrm{~A}$ \\
\hline 701 & $8,35 \mathrm{BCa}$ & $6,83 \mathrm{BCab}$ & $4,55 \mathrm{Bb}$ & $3,37 \mathrm{Ab}$ & $2,60 \mathrm{Bb}$ & $3,70 \mathrm{ABb}$ & $4,90 \mathrm{BC}$ \\
\hline 425 & $7,43 \mathrm{Ca}$ & $5,07 \mathrm{Cb}$ & $3,47 \mathrm{Bbc}$ & 3,33 Abc & $2,10 \mathrm{Bc}$ & $3,05 \mathrm{ABbc}$ & $4,07 \mathrm{C}$ \\
\hline Médias & $9,43 \mathrm{a}$ & $7,55 \mathrm{~b}$ & $5,46 \mathrm{c}$ & $4,17 \mathrm{~d}$ & $3,07 \mathrm{de}$ & $2,85 \mathrm{e}$ & 5,42 \\
\hline
\end{tabular}

- Médias seguidas por letras iguais, maiúsculas na vertical ou minúsculas na horizontal, não diferem entre si pelo teste de Tukey . ao nível de $5 \%$ de probabilidade. 


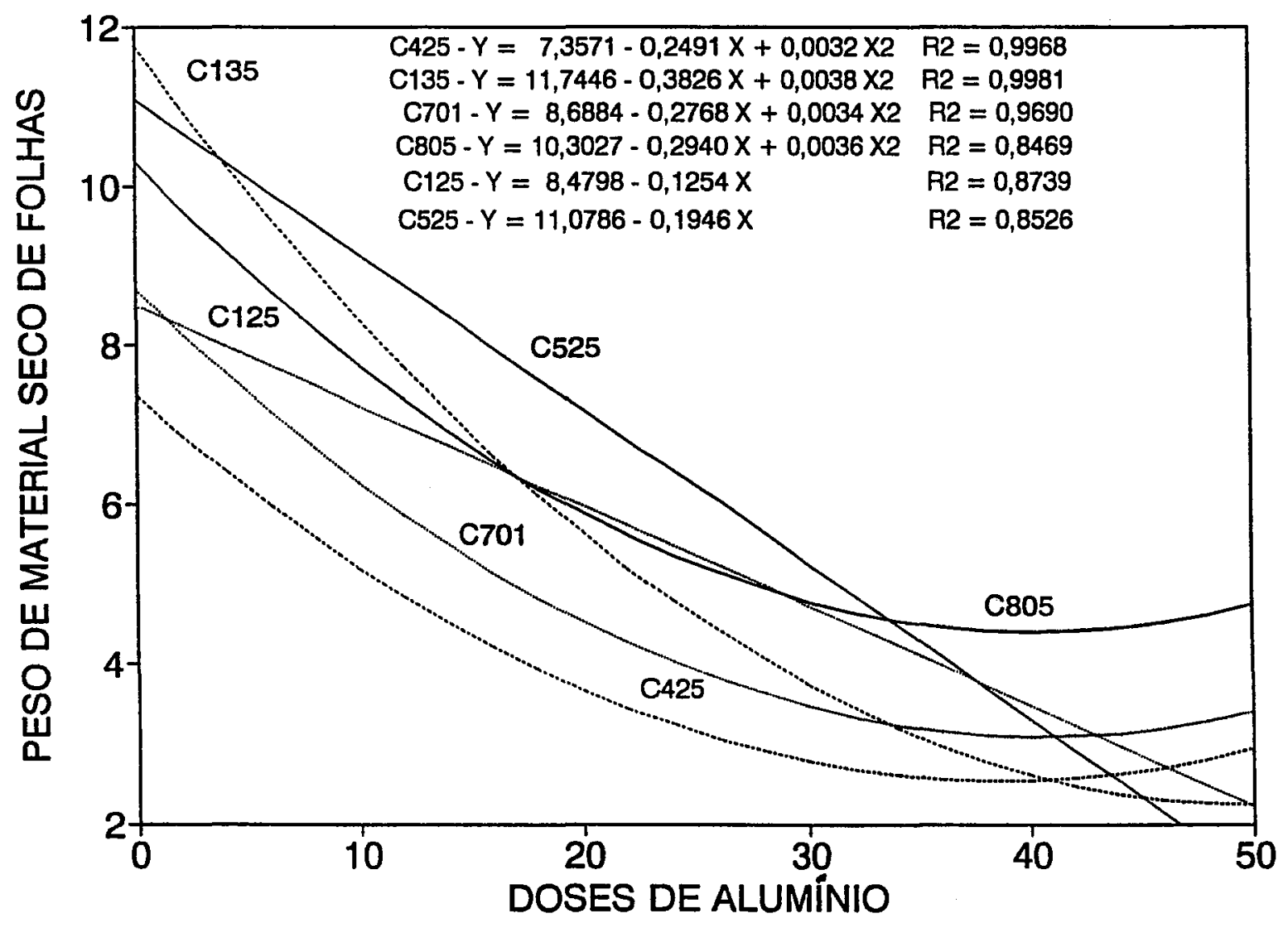

Figura 1. Regressões entre o peso de material seco das folhas (g.planta-1) e os níveis de alumínio (mg. $\mathrm{L}^{\mathbf{- 1}}$ ) para os seis cultivares estudados. 
apresentaram reduções representadas por equações de segundo grau, com mínimos em 38,$9 ; 40,7 ; 40,8$ e 50,3 mg.L $\mathrm{L}^{-1}$ de alumínio para os cultivares $\mathrm{C} 425$, C701, C805 e C135 respectivamente.

Na Tabela 1 observa-se que, na ausência de alumínio os cultivares C135, C805 e C525 apresentaram peso de folhas significativamente maiores que os demais, exceto o último, que não diferiu dos cultivares C125 e C701. Com o aumento do nível de alumínio da solução, foi o cultivar C525 que apresentou os maiores pesos de folhas até $30 \mathrm{mg} . \mathrm{L}^{-1}$, quando não diferiu dos demais e tornou-se menor que os outros cultivares, no nivel $50 \mathrm{mg} . \mathrm{L}^{\mathbf{- 1}}$.

A Tabela 2 apresenta o peso do material seco das raizes (g.planta-1) em função dos níveis de alumínio estudados $\left(\mathrm{mg} . \mathrm{L}^{-1}\right)$, dentro de cada cultivar. Observa-se que os cultivares, embora tenham todos apresentado redução no peso do material seco das raízes com o aumento da concentração de alumínio da solução, apresentaram comportamentos diferentes em relação aos niveis de alumínio. Assim, os cultivares C125 e C805 não apresentaram redução significativa no peso das raízes com até $20 \mathrm{mg} . \mathrm{L}^{-1}$ de alumínio na solução, reduzindo seu peso somente a partir de $30 \mathrm{mg} . \mathrm{L}^{-1}$; os cultivares C525, C701 e C425 não apresentaram redução no peso das raizes até $10 \mathrm{mg} . \mathrm{L}^{-1}$, não apresentando uma queda significativa nos demais níveis. O cultivar C135 apresentou redução progressiva no peso das raízes, em função dos níveis de alumínio da solução.

O comportamento do peso do material seco das raízes em cada cultivar, em função dos níveis de alumínio aplicados, é apresentado na Figura 2, onde são representadas as equações de regressões entre o peso do material seco das raízes (g.planta-1) e as doses de alumínio (mg.L-1), para os seis cultivares estudados. Assim, todas as regressões representam a redução do peso das raízes em função dos níveis de alumínio, porém os cultivares C525, C125 e C805 apresentaram reduções representadas por equações lineares, enquanto os demais cultivares apresentaram reduções representadas por equações quadráticas, com mínimos em 37,0; 49,4 e 53,0 mg.L $\mathbf{~}^{-1}$ de alumínio para os cultivares C425, C701 e $\mathrm{C} 135$ respectivamente. Observa-se que o sistema radicular do cultivar C805 foi sempre mais pesado que o dos demais cultivares, qualquer que fosse o nível de alumínio presente na solução nutritiva. 
Tabela 2. Peso do material seco das raízes (g.planta ${ }^{-1}$ ) em função dos níveis de alumínio estudados (mg. $\left.\mathrm{L}^{-1}\right)$, dentro de cada cultivar (médias de quatro repetições).

\begin{tabular}{|c|c|c|c|c|c|c|c|}
\hline \multirow[t]{2}{*}{ Cultivares } & \multicolumn{6}{|c|}{ Alumínio (mg. $\mathrm{L}^{-1}$ ) } & \multirow[t]{2}{*}{ Médias } \\
\hline & 0 & 10 & 20 & 30 & 40 & 50 & \\
\hline 525 & $8,33 \mathrm{ABa}$ & $6,23 \mathrm{ABab}$ & 4,77 Abcd & 4,10 Abcd & 3,33 ABcd & $1,87 \mathrm{Ad}$ & $4,77 \mathrm{~B}$ \\
\hline 135 & $8,50 \mathrm{Aa}$ & $5,83 \mathrm{ABb}$ & $4,37 \mathrm{BCbc}$ & $3,65 \mathrm{Abc}$ & $2,55 \mathrm{ABc}$ & $2,10 \mathrm{Ac}$ & $4,50 \mathrm{~B}$ \\
\hline 125 & $7,13 \mathrm{ABa}$ & 5,27 ABab & $5,77 \mathrm{ABa}$ & 3,07 Abc & $2,20 \mathrm{BC}$ & $2,17 \mathrm{Ac}$ & $4,27 \mathrm{~B}$ \\
\hline 805 & $8,45 \mathrm{Aa}$ & 7,37 Aa & 6,77 Aab & $4,30 \mathrm{Ac}$ & $4,87 \mathrm{Abc}$ & $3,17 \mathrm{Ac}$ & $5,83 \mathrm{~A}$ \\
\hline 701 & $6,55 \mathrm{ABa}$ & 5,07 ABab & $3,30 \mathrm{Cbc}$ & $2,80 \mathrm{Abc}$ & $1,77 \mathrm{Bc}$ & $2,00 \mathrm{Ac}$ & $3,58 \mathrm{C}$ \\
\hline 425 & $6,05 \mathrm{Ba}$ & 4,40 Bab & $3,13 \mathrm{Cbc}$ & $3,10 \mathrm{Abc}$ & $1,67 \mathrm{Bc}$ & $3,17 \mathrm{Abc}$ & $3,59 \mathrm{C}$ \\
\hline Médias & $7,50 \mathrm{a}$ & $5,70 \mathrm{~b}$ & $4,69 \mathrm{c}$ & $3,50 \mathrm{~d}$ & $2,73 \mathrm{e}$ & $2,42 \mathrm{e}$ & 4,42 \\
\hline
\end{tabular}

- Médias seguidas por letras iguais, maiúsculas na vertical ou minúsculas na horizontal, não diferem entre si pelo teste de Tukey ao nivel de $5 \%$ de probabilidade. 


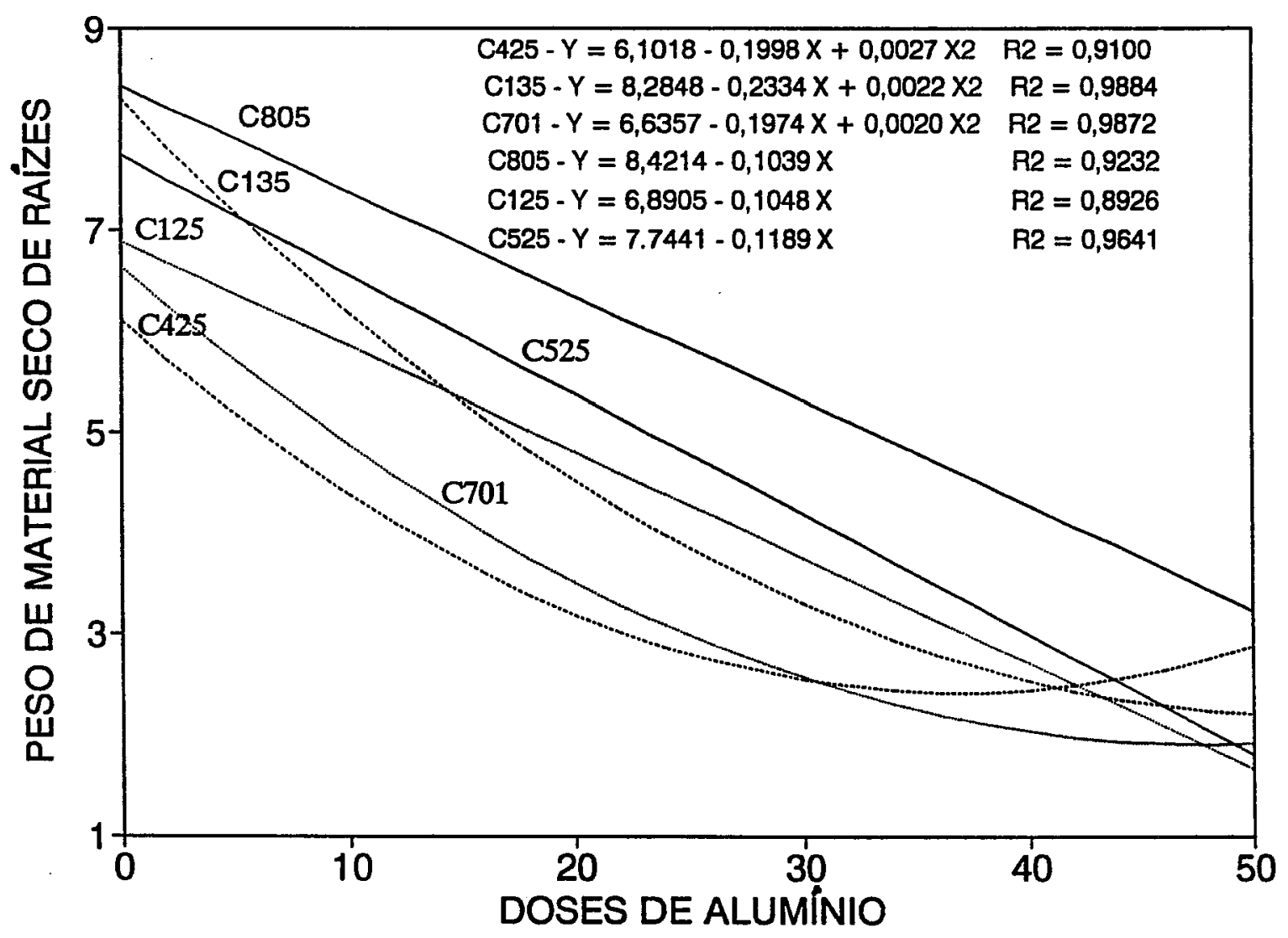

Figura 2. Regressões entre o peso de material seco das raízes (g.planta-1) e os níveis de alumínio (mg.L-1) para os seis cultivares estudados. 
Na Tabela 2 observa-se que, na ausência de alumínio, os cultivares C135 e C805 apresentaram peso das raízes significativamente maiores que os do cultivar C425, não diferindo dos pesos dos demais cultivares. O nível $20 \mathrm{mg} . \mathrm{L}^{\mathbf{- 1}}$ foi o que melhor diferenciou os cultivares quanto ao seu comportamento em relação ao alumínio. Assim, nesse nível, os cultivares C525 e C805 apresentaram os maiores pesos de raízes, diferindo significativamente dos demais, exceto do cultivar $\mathrm{C} 125$, que não foi estatisticamente diferente deles.

A Tabela 3 apresenta o peso do material seco dos colmos (g.planta-1 em função dos níveis de alumínio estudados $\left(\mathrm{mg}^{-L^{-1}}\right)$, dentro de cada cultivar. Observa-se que os cultivares, embora tenham todos apresentado redução no peso do material seco dos colmos com o aumento da concentração de alumínio da solução, exceto o cultivar C425 que não apresentou redução significativa no peso dos colmos, apresentaram comportamentos diversos em relação aos níveis de alumínio. Assim, o cultivar $\mathrm{C} 125$ praticamente não apresentou redução significativa no peso dos colmos com até $20 \mathrm{mg} . \mathrm{L}^{-1}$ de alumínio na solução, reduzindo seu peso somente a partir de $30 \mathrm{mg} . \mathrm{L}^{\mathbf{- 1}}$; os cultivares C525 e C135 não apresentaram redução no peso dos colmos até $10 \mathrm{mg} . \mathrm{L}^{\mathbf{- 1}}$, sendo que enquanto o primeiro não apresentava uma queda significativa nos demais níveis, o segundo apresentou redução significativa de peso nas mesmas condições. Os cultivares C805 e C701 apresentaram redução no peso dos colmos somente no nível 10 mg.L $\mathrm{L}^{\mathbf{1}}$, permanecendo com praticamente o mesmo peso nos demais níveis.

O comportamento do peso do material seco dos colmos em cada cultivar, em função dos níveis de alumínio aplicados, é apresentado na Figura 3, onde são representadas as equações de regressões entre o peso do material seco dos colmos (g.planta-1) e os níveis de alumínio (mg.L $\left.{ }^{-1}\right)$, para cinco dos seis cultivares estudados, uma vez que o cultivar C425 não apresentou redução de peso dos colmos em função dos níveis de alumínio. Assim, todas as regressões representam a redução do peso dos colmos em função dos níveis de alumínio, porém os cultivares C135 e C125 apresentaram reduções representadas por equações de primeiro grau, enquanto os demais cultivares apresentaram reduções representadas por equações de segundo grau, com mínimos em 37,2; 41,6 e 50,2 mg.L-1 de alumínio para os cultivares C805, C701 e C525 respectivamente. 
Tabela 3. Peso do material seco dos colmos (g.planta ${ }^{-1}$ em função dos níveis de alumínio estudados (mg. $\mathrm{L}^{-1}$ ), dentro de cada cultivar (médias de quatro repetições).

\begin{tabular}{|c|c|c|c|c|c|c|c|}
\hline \multirow[t]{2}{*}{ Cultivares } & \multicolumn{6}{|c|}{ Alumínio (mg. $\mathrm{L}^{-1}$ ) } & \multirow[t]{2}{*}{ Médias } \\
\hline & 0 & 10 & 20 & 30 & 40 & 50 & \\
\hline 525 & $9,70 \mathrm{Aa}$ & $10,35 \mathrm{Aa}$ & $3,85 \mathrm{ABb}$ & $3,13 \mathrm{Ab}$ & $2,17 \mathrm{ABb}$ & $2,25 \mathrm{Ab}$ & $5,24 \mathrm{~A}$ \\
\hline 135 & $8,20 \mathrm{Aa}$ & $6,23 \mathrm{Bab}$ & $5,17 \mathrm{Abc}$ & 2,93 Acd & $2,00 \mathrm{ABd}$ & $1,70 \mathrm{Ad}$ & $4,37 \mathrm{AB}$ \\
\hline 125 & $7,60 \mathrm{ABa}$ & $5,57 \mathrm{Ba}$ & $5,97 \mathrm{Aa}$ & $3,20 \mathrm{Ab}$ & $2,85 \mathrm{ABb}$ & $2,37 \mathrm{Ab}$ & $4,60 \mathrm{AB}$ \\
\hline 805 & 7,93 Aa & $4,03 \mathrm{BCb}$ & $3,83 \mathrm{ABb}$ & $2,40 \mathrm{Ab}$ & $3,35 \mathrm{Ab}$ & $2,60 \mathrm{Ab}$ & $4,02 \mathrm{~B}$ \\
\hline 701 & $5,47 \mathrm{BCa}$ & $3,03 \mathrm{Cb}$ & $1,87 \mathrm{Bb}$ & $1,50 \mathrm{Ab}$ & $0,80 \mathrm{Bb}$ & $0,93 \mathrm{Ab}$ & $2,27 \mathrm{C}$ \\
\hline 425 & $3,70 \mathrm{Ca}$ & $2,43 \mathrm{Ca}$ & $2,20 \mathrm{Ba}$ & $1,73 \mathrm{Aa}$ & $2,55 \mathrm{ABa}$ & $1,70 \mathrm{Aa}$ & $2,38 \mathrm{C}$ \\
\hline Médias & $7,10 \mathrm{a}$ & $5,27 \mathrm{~b}$ & $3,82 \mathrm{c}$ & $2,48 d$ & $2,21 \mathrm{~d}$ & $2,00 \mathrm{~d}$ & 3,81 \\
\hline
\end{tabular}

- Médias seguidas por letras iguais, maiúsculas na vertical ou minúsculas na horizontal, não diferem entre si pelo teste de Tukey ao nível de $5 \%$ de probabilidade. 


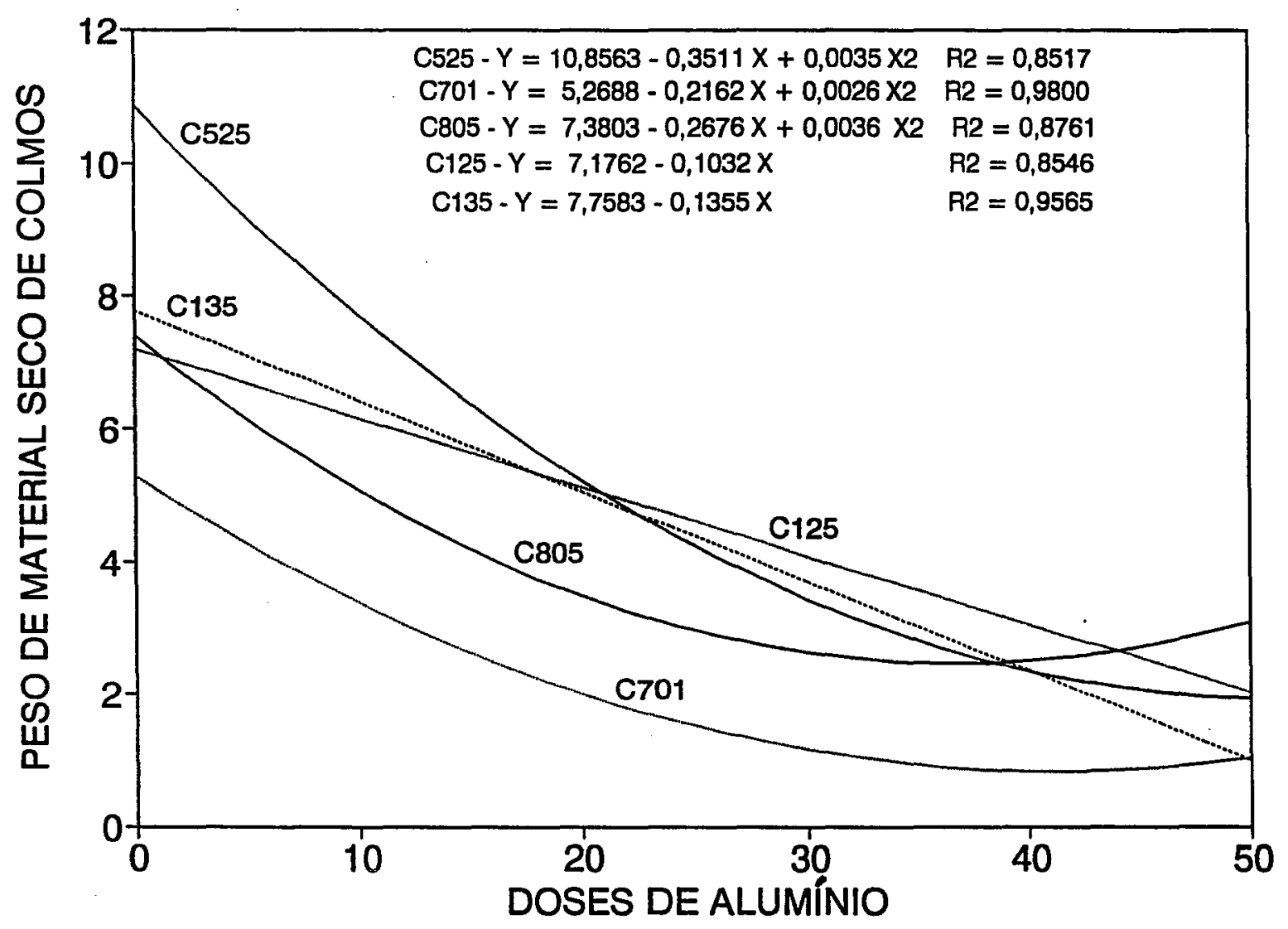

Figura 3. Regressões entre o peso de material seco dos colmos (g.planta-1) e os níveis de alumínio (mg.L-1) para quatro dos seis cultivares estudados. 
$\mathrm{Na}$ Tabela 3 observa-se que, na ausência de alumínio os cultivares C135, C805, C525 e C125 apresentaram peso dos colmos significativamente maiores que os demais, exceto o último, que não diferiu do cultivar C701. Com o aumento do nível de alumínio da solução, foi o cultivar C525 que apresentou os maiores pesos de colmos até $20 \mathrm{mg} . \mathrm{L}^{-1}$, quando não diferiu dos demais, tornou-se semelhante aos pesos dos outros cultivares nos níveis maiores.

A Tabela 4 apresenta o peso do material seco (g.planta-1) das partes amostradas dentro de cada cultivar, para os níveis 0 e $10 \mathrm{mg} . \mathrm{L}^{-1}$ de alumínio na solução. Observa-se que na ausência de alumínio, os cultivares já apresentavam comportamentos diferentes em relação à distribuição da massa entre as três partes amostradas. Assim, os cultivares C125, C525 e C701 apresentavam as três partes com pesos estatisticamente semelhantes, enquanto os cultivares $\mathrm{C} 135$ e C805 apresentavam o peso das folhas superior ao das demais partes e o cultivar C425 apresentava o colmo com peso significativamente menor que as demais partes. Ainda na ausência de alumínio, quanto ao peso seco das folhas, os cultivares C525, C135 e C805 apresentaram valores significativamente maiores que os demais cultivares, que não diferiram entre si; quanto ao peso seco das raízes, os cultivares $\mathrm{C} 135$ e C805 não diferiram dos demais, exceto dos cultivar C425; quanto ao peso seco dos colmos, os cultivares C525, C135 e C805 não diferiram do cultivar $\mathrm{C} 125$, que foi estatisticamente diferente do cultivar $\mathrm{C} 425$.

No nível $10 \mathrm{mg} . \mathrm{L}^{\mathbf{- 1}}$ de alumínio, observa-se que os cultivares também apresentavam comportamentos diversos em relação à distribuição da massa entre as três partes amostradas. Assim, o cultivar C125 apresentava as três partes com pesos estatisticamente semelhantes, enquanto os cultivares C525 e C135 apresentavam os pesos das folhas e dos colmos maiores que os das raízes e os cultivares C805, C701 e C425 apresentavam as folhas e as raizes mais pesadas que os colmos. Ainda no nível $10 \mathrm{mg} . \mathrm{L}^{\mathbf{- 1}}$ de alumínio, quanto ao peso seco das folhas, o cultivar C525 apresentou valores significativamente maiores que os demais cultivares; quanto ao peso seco das raízes, o cultivar C805 somente foi estatisticamente maior que o cultivar $\mathrm{C} 425$; quanto ao peso seco dos colmos, o cultivar C525 diferiu estatisticamente dos demais cultivares.

A Tabela 5 apresenta o peso do material seco (g.planta-1) das partes amostradas dentro de cada cultivar, para os niveis 20 e $30 \mathrm{mg} . \mathrm{L}^{-1}$ de alumínio na 
Tabela 4: Peso do material seco (g.planta ${ }^{-1}$ ) em função das partes amostradas, dentro de cada cultivar, para os níveis 0 e $10 \mathrm{mg} . \mathrm{L}^{-1}$ de alumínio (médias de quatro repetições).

\begin{tabular}{||c|c|c|c|c||}
\hline \multirow{2}{*}{ Cultivares } & \multicolumn{5}{|c|}{ Nível 0 de Alumínio } \\
\cline { 2 - 5 } & Folhas & Raízes & Colmos & Médias \\
\hline 525 & $9,97 \mathrm{Aba}$ & $8,33 \mathrm{ABa}$ & $9,70 \mathrm{Aa}$ & $9,33 \mathrm{AB}$ \\
\hline 135 & $11,75 \mathrm{Aa}$ & $8,50 \mathrm{Ab}$ & $8,20 \mathrm{Ab}$ & $9,48 \mathrm{~A}$ \\
\hline 125 & $7,87 \mathrm{BCa}$ & $7,13 \mathrm{ABa}$ & $7,60 \mathrm{ABa}$ & $7,53 \mathrm{BC}$ \\
\hline 805 & $11,23 \mathrm{Aa}$ & $8,45 \mathrm{Ab}$ & $7,93 \mathrm{Ab}$ & $9,20 \mathrm{AB}$ \\
\hline 701 & $8,35 \mathrm{BCa}$ & $6,55 \mathrm{ABab}$ & $5,47 \mathrm{BCa}$ & $6,79 \mathrm{C}$ \\
\hline 425 & $7,43 \mathrm{Ca}$ & $6,05 \mathrm{Ba}$ & $3,70 \mathrm{Cb}$ & $5,73 \mathrm{C}$ \\
\hline Médias & $9,43 \mathrm{a}$ & $7,50 \mathrm{~b}$ & $7,10 \mathrm{~b}$ & 8,01 \\
\hline & & Nivel $10 \mathrm{de} \mathrm{Alumínio}$ & \\
\hline 525 & $11,85 \mathrm{Aa}$ & $6,23 \mathrm{ABb}$ & $10,35 \mathrm{Aa}$ & $9,47 \mathrm{~A}$ \\
\hline 135 & $8,30 \mathrm{Ba}$ & $5,83 \mathrm{ABb}$ & $6,23 \mathrm{Bab}$ & $6,78 \mathrm{~B}$ \\
\hline 125 & $7,10 \mathrm{BCa}$ & $5,27 \mathrm{ABa}$ & $5,57 \mathrm{Ba}$ & $6,98 \mathrm{BC}$ \\
\hline 805 & $6,15 \mathrm{BCab}$ & $7,35 \mathrm{Aa}$ & $4,03 \mathrm{BCb}$ & $5,85 \mathrm{BC}$ \\
\hline 701 & $6,83 \mathrm{BCa}$ & $5,07 \mathrm{ABab}$ & $3,03 \mathrm{Cb}$ & $4,97 \mathrm{BC}$ \\
\hline 425 & $5,07 \mathrm{Ca}$ & $4,40 \mathrm{Bab}$ & $2,43 \mathrm{Cb}$ & $3,97 \mathrm{C}$ \\
\hline Médias & $7,55 \mathrm{a}$ & $5,69 \mathrm{a}$ & $5,27 \mathrm{a}$ & 6,17 \\
\hline \hline
\end{tabular}

- Médias seguidas por letras iguais, maiúsculas na vertical ou minúsculas na horizontal, dentro de cada nível de alumínio, não diferem entre si pelo teste de Tukey ao nível de $5 \%$ de probabilidade 
Tabela 5: Peso do material seco (g.planta ${ }^{-1}$ ) em função das partes amostradas, dentro de cada cultivar, para os níveis 20 e $30 \mathrm{mg} \cdot \mathrm{L}^{-1}$ de alumínio (médias de quatro repetições).

\begin{tabular}{||c|c|c|c|c||}
\hline \multirow{2}{*}{ Cultivares } & \multicolumn{5}{|c|}{ Pável 20 de Alumínio } \\
\cline { 2 - 5 } & Folhas & Raízes & Colmos & Médias \\
\hline 525 & $5,55 \mathrm{ABa}$ & $4,77 \mathrm{ABCa}$ & $3,85 \mathrm{ABa}$ & $4,73 \mathrm{~B}$ \\
\hline 135 & $5,70 \mathrm{ABa}$ & $4,37 \mathrm{BCb}$ & $5,17 \mathrm{Aab}$ & $5,08 \mathrm{~B}$ \\
\hline 125 & $7,75 \mathrm{Aa}$ & $5,77 \mathrm{ABa}$ & $5,97 \mathrm{Aa}$ & $6,50 \mathrm{~A}$ \\
\hline 805 & $5,73 \mathrm{ABab}$ & $6,77 \mathrm{Aa}$ & $3,83 \mathrm{ABCb}$ & $5,44 \mathrm{AB}$ \\
\hline 701 & $4,55 \mathrm{Ba}$ & $3,30 \mathrm{Cab}$ & $1,87 \mathrm{Cb}$ & $3,24 \mathrm{C}$ \\
\hline 425 & $3,47 \mathrm{Ba}$ & $3,13 \mathrm{Ca}$ & $2,20 \mathrm{BCa}$ & $2,93 \mathrm{C}$ \\
\hline Médias & $5,46 \mathrm{a}$ & $4,69 \mathrm{~b}$ & $3,82 \mathrm{~b}$ & 4,66 \\
\hline & & Nível $30 \mathrm{de} \mathrm{Alumíni}$ & \\
\hline 525 & $5,13 \mathrm{Aa}$ & $4,10 \mathrm{Aa}$ & $3,13 \mathrm{Aa}$ & $4,12 \mathrm{~A}$ \\
\hline 135 & $3,50 \mathrm{Aa}$ & $3,65 \mathrm{Aa}$ & $2,93 \mathrm{Aa}$ & $3,36 \mathrm{~A}$ \\
\hline 125 & $4,20 \mathrm{Aa}$ & $3,07 \mathrm{Aa}$ & $3,20 \mathrm{Aa}$ & $3,49 \mathrm{AB}$ \\
\hline 805 & $5,47 \mathrm{Aa}$ & $4,30 \mathrm{Aab}$ & $2,40 \mathrm{Ab}$ & $4,06 \mathrm{~A}$ \\
\hline 701 & $3,37 \mathrm{Aa}$ & $2,80 \mathrm{Aa}$ & $1,50 \mathrm{Aa}$ & $2,56 \mathrm{C}$ \\
\hline 425 & $3,33 \mathrm{Aa}$ & $3,10 \mathrm{Aa}$ & $1,73 \mathrm{Aa}$ & $2,72 \mathrm{BC}$ \\
\hline Médias & $4,17 \mathrm{a}$ & $3,50 \mathrm{~b}$ & $2,48 \mathrm{c}$ & 3,38 \\
\hline
\end{tabular}

- Médias seguidas por letras iguais, maiúsculas na vertical ou minúsculas na horizontal, dentro de cada nível de alumínio, não diferem entre si pelo teste de Tukey ao nível de $5 \%$ de probabilidade 
solução. Observa-se que no nível $20 \mathrm{mg} . \mathrm{L}-1$ de alumínio, os cultivares apresentaram comportamentos distintos em relação à distribuição da massa entre as três partes amostradas. Assim, os cultivares C525, C125 e C425 apresentavam as três partes com pesos estatisticamente semelhantes, enquanto os demais cultivares apresentavam dois pesos diferentes e outro que não diferiu estatisticamente dos dois. Assim, o cultivar C135 apresentou o peso das folhas e das raízes diferentes; o cultivar C805 apresentou peso de raízes e de colmos diferentes e o cultivar C701 o peso de folhas e colmos. Ainda no nível $20 \mathrm{mg} . \mathrm{L}^{-1}$ de alumínio, quanto ao peso seco das folhas, o cultivar C125 apresentou valores significativamente maiores que os cultivares $\mathrm{C} 701$ e C425 e não diferiram dos demais; quanto ao peso seco das raízes, os cultivares C805, C125 e C525 não diferiram entre si, mas os dois últimos também não foram diferentes do cultivar $\mathrm{C} 135$, que junto com o último não diferiram dos demais; quanto ao peso seco dos colmos, os cultivares C125 e C135 diferiram dos cultivares C701 e C425.

No nível $30 \mathrm{mg} . \mathrm{L}^{\mathbf{- 1}}$ de alumínio, observa-se que os cultivares também apresentaram comportamentos diversos em relação à distribuição da massa entre as três partes amostradas. Assim, somente o cultivar C805 apresentou os pesos de folhas e de colmos estatisticamente diferentes, pois para os demais cultivares as três partes apresentavam pesos estatisticamente semelhantes. Ainda no nível $30 \mathrm{mg} . \mathrm{L}^{-1}$ de alumínio, os cultivares não diferiram estatisticamente entre si em nenhuma das partes amostradas.

A Tabela 6 apresenta o peso do material seco (g.planta-1) das partes amostradas dentro de cada cultivar, para os níveis 40 e $50 \mathrm{mg} . \mathrm{L}^{-1}$ de alumínio na solução. Observa-se que no nível $40 \mathrm{mg} . \mathrm{L}^{-1}$ de alumínio, os cultivares não apresentaram comportamentos diferentes em relação à distribuição da massa entre as três partes amostradas, pois em qualquer dos cultivares estudados as três partes amostradas apresentaram pesos estatisticamente semelhantes. Ainda no nível 40 mg.L $\mathbf{~}^{-1}$ de alumínio, quanto ao peso seco das folhas e das raízes, o cultivar C805 apresentou valor significativamente maior que os cultivares C125, C701 e C425, não diferindo dos demais; quanto ao peso seco dos colmos, os cultivares não diferiram entre si.

No nível 50 mg.L $\mathbf{~}^{-1}$ de alumínio, observa-se que os cultivares já apresentaram comportamentos diversos em relação à distribuição da massa entre as três partes amostradas. Assim, o cultivar C701 apresentou o peso das folhas 
Tabela 6: Peso do material seco (g.planta-1) em função das partes amostradas, dentro de cada cultivar, para os níveis 40 e $50 \mathrm{mg} . \mathrm{L}^{-1}$ de alumínio (médias de quatro repetições).

\begin{tabular}{||c|c|c|c|c||}
\hline \multirow{2}{*}{ Cultivares } & \multicolumn{5}{|c|}{ Nível 40 de Alumínio } \\
\cline { 2 - 5 } & Folhas & Raízes & Colmos & Médias \\
\hline 525 & $3,07 \mathrm{ABa}$ & $3,33 \mathrm{ABa}$ & $2,17 \mathrm{ABa}$ & $2,86 \mathrm{~B}$ \\
\hline 135 & $2,85 \mathrm{ABa}$ & $2,55 \mathrm{ABa}$ & $2,00 \mathrm{ABa}$ & $2,47 \mathrm{BC}$ \\
\hline 125 & $2,70 \mathrm{Ba}$ & $2,20 \mathrm{Ba}$ & $2,37 \mathrm{ABa}$ & $2,43 \mathrm{BC}$ \\
\hline 805 & $5,13 \mathrm{Aa}$ & $4,87 \mathrm{Aa}$ & $3,35 \mathrm{Ba}$ & $4,45 \mathrm{~A}$ \\
\hline 701 & $2,60 \mathrm{Ba}$ & $1,77 \mathrm{Ba}$ & $0,80 \mathrm{Ba}$ & $1,73 \mathrm{D}$ \\
\hline 425 & $2,10 \mathrm{Ba}$ & $1,67 \mathrm{Ba}$ & $2,55 \mathrm{ABa}$ & $2,11 \mathrm{CD}$ \\
\hline Médias & $3,07 \mathrm{a}$ & $2,73 \mathrm{a}$ & $2,21 \mathrm{~b}$ & 2,67 \\
\hline & & Nível $50 \mathrm{de} \mathrm{Alumi}$ & & \\
\hline 525 & $1,70 \mathrm{Ba}$ & $1,88 \mathrm{Aa}$ & $2,25 \mathrm{Aa}$ & $1,94 \mathrm{~B}$ \\
\hline 135 & $2,15 \mathrm{ABa}$ & $2,10 \mathrm{Aa}$ & $1,70 \mathrm{Aa}$ & $1,98 \mathrm{~B}$ \\
\hline 125 & $2,45 \mathrm{ABa}$ & $2,17 \mathrm{Aa}$ & $2,85 \mathrm{Aa}$ & $2,49 \mathrm{~B}$ \\
\hline 805 & $4,07 \mathrm{Aa}$ & $3,17 \mathrm{Aa}$ & $2,60 \mathrm{Aa}$ & $3,28 \mathrm{~A}$ \\
\hline 701 & $3,70 \mathrm{ABa}$ & $2,00 \mathrm{Aab}$ & $0,93 \mathrm{Ab}$ & $2,21 \mathrm{~B}$ \\
\hline 425 & $3,05 \mathrm{ABa}$ & $3,17 \mathrm{Aa}$ & $1,70 \mathrm{Aa}$ & $2,64 \mathrm{AB}$ \\
\hline Médias & $2,85 \mathrm{a}$ & $2,42 \mathrm{~b}$ & $2,00 \mathrm{c}$ & 2,43 \\
\hline \hline
\end{tabular}

- Médias seguidas por letras iguais, maiúsculas na vertical ou minúsculas na horizontal, dentro de cada nível de alumínio, não diferem entre si pelo teste de Tukey ao nível de $5 \%$ de probabilidade 
estatisticamente diferente do peso dos colmos, enquanto para os demais cultivares os pesos das três partes amostradas não diferiram entre si. Ainda no nível 50 mg.L $\mathbf{~}^{-1}$ de alumínio, quanto ao peso seco das folhas, o cultivar C805 apresentou peso significativamente maior que o cultivar C525, não diferindo dos demais; quanto ao peso seco das raízes e de colmos, os cultivares não diferiram entre si.

\subsection{Extração de nitrogênio}

A Tabela 7 apresenta a extração de nitrogênio pelas folhas (mg.planta-1) em função dos níveis de alumínio estudados (mg.L-1), dentro de cada cultivar. Observa-se que os cultivares, embora tenham todos apresentado redução na extração de nitrogênio pelas folhas com o aumento da concentração de alumínio da solução, apresentaram comportamentos diversos em relação aos níveis de alumínio. Assim, o cultivar $\mathrm{C} 125$ não apresentou estatisticamente redução na extração de nitrogênio pelas folhas com até $20 \mathrm{mg} . \mathrm{L}^{-1}$ de alumínio na solução, reduzindo sua extração somente a partir de $30 \mathrm{mg} . \mathrm{L}^{-1}$; os cultivares C525 e C701 não apresentaram redução na extração pelas folhas atẻ $10 \mathrm{mg} . \mathrm{L}^{-1} \mathrm{e}$ enquanto o primeiro apresentava uma queda significativa nos demais níveis, o segundo não apresentou redução significativa na extração nas mesmas condições, os cultivares C805 e C135 apresentaram redução na extração de nitrogênio pelas folhas a partir de $10 \mathrm{mg} . \mathrm{L}^{-1}$ de aluminio, sendo que o primeiro não apresentou redução estatisticamente significativa nos níveis maiores que esse, enquanto o segundo cultivar continuou reduzindo a sua extração de nitrogênio.

O comportamento da extração de nitrogênio pelas folhas em cada cultivar, em função dos níveis de alumínio aplicados, é apresentado na Figura 4, onde são representadas as equações de regressão entre a extração de nitrogênio pelas folhas (mg.planta-1) e as doses de aluminio (mg.L ${ }^{-1}$ ), para os seis cultivares estudados. Assim, todas as regressões representam a redução da extração de nitrogênio pelas folhas em função dos níveis de alumínio, porém os cultivares C125, C425, C135, C525 e C805 apresentaram reduções representadas por equações de primeiro grau, enquanto o cultivar C701 apresentou redução representada por equação de segundo grau, com mínimo em $35,2 \mathrm{mg} . \mathrm{L}^{\mathbf{- 1}}$ de alumínio. 
Tabela 7. Extração de nitrogênio pelas folhas (mg.planta $\left.{ }^{-1}\right)$ em função dos níveis de alumínio estudados (mg. $\mathrm{L}^{-1}$ ), dentro de cada cultivar (médias de quatro repetições).

\begin{tabular}{|c|c|c|c|c|c|c|c|}
\hline \multirow[t]{2}{*}{ Cultivares } & \multicolumn{6}{|c|}{ Alumínio (mg. $\left.\mathrm{L}^{-1}\right)$} & \multirow[t]{2}{*}{ Médias } \\
\hline & 0 & 10 & 20 & 30 & 40 & 50 & \\
\hline 525 & $259,56 \mathrm{Ab}$ & $328,26 \mathrm{Aa}$ & $138,10 \mathrm{ABc}$ & $115,79 \mathrm{Acd}$ & 71,13 ABde & $39,02 \mathrm{Ae}$ & $158,80 \mathrm{~A}$ \\
\hline 135 & $269,07 \mathrm{Aa}$ & $202,06 \mathrm{Bb}$ & $135,91 \mathrm{ABC}$ & $112,73 \mathrm{Ac}$ & $55,85 \mathrm{ABd}$ & $42,67 \mathrm{Ad}$ & $136,38 \mathrm{~A}$ \\
\hline 125 & $216,10 \mathrm{Aa}$ & $178,77 \mathrm{Ba}$ & $188,80 \mathrm{Aa}$ & $89,59 \mathrm{ABb}$ & $54,67 \mathrm{ABb}$ & $46,32 \mathrm{Ab}$ & $129,19 \mathrm{~A}$ \\
\hline 805 & $151,01 \mathrm{Ba}$ & $88,32 \mathrm{Cb}$ & $92,37 \mathrm{BCb}$ & $100,43 \mathrm{ABab}$ & $97,21 \mathrm{Aab}$ & $79,30 \mathrm{Ab}$ & $101,44 \mathrm{~B}$ \\
\hline 701 & $130,93 \mathrm{BCa}$ & $92,74 \mathrm{Cab}$ & $56,11 \mathrm{Cb}$ & $49,03 \mathrm{Bb}$ & $40,76 \mathrm{Bb}$ & $60,84 \mathrm{Ab}$ & $71,77 \mathrm{C}$ \\
\hline 425 & $94,80 \mathrm{Ca}$ & $68,20 \mathrm{Cab}$ & $51,87 \mathrm{Cab}$ & $49,89 \mathrm{Bab}$ & $35,10 \mathrm{Bb}$ & 50,47 Aab & $58,54 \mathrm{C}$ \\
\hline Médias & $187,06 \mathrm{a}$ & $159,76 \mathrm{a}$ & $110,67 \mathrm{~b}$ & $86,24 \mathrm{bc}$ & $59,27 \mathrm{~cd}$ & $53,10 \mathrm{~d}$ & 109,35 \\
\hline
\end{tabular}

- Médias seguidas por letras iguais, maiúsculas na vertical ou minúsculas na horizontal, não diferem entre si pelo teste de Tukey ao nível de 5\% de probabilidade. 


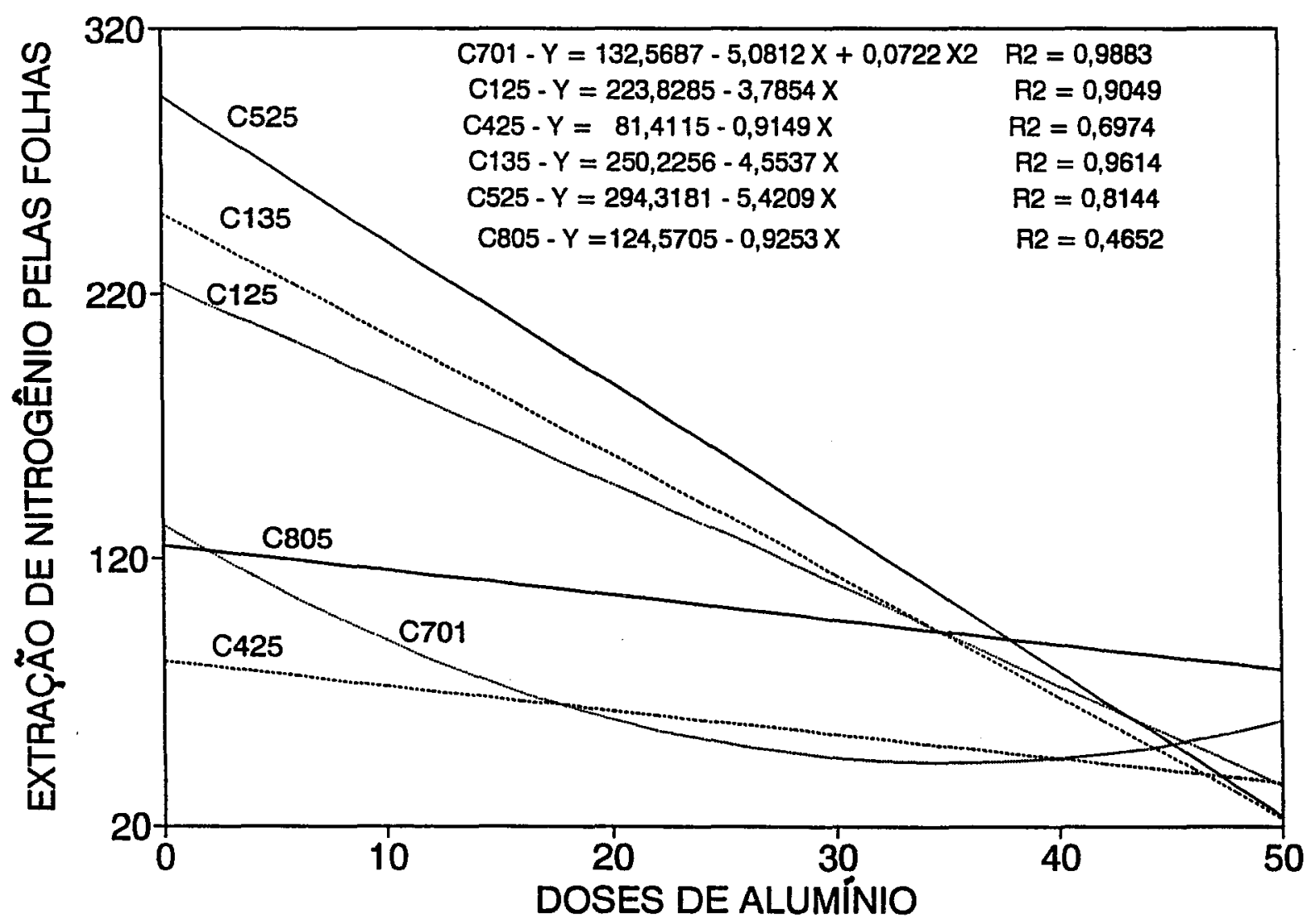

Figura 4. Regressões entre a extração de nitrogênio pelas folhas (g.planta-1) e os níveis de alumínio (mg.L $\mathbf{~}^{-1}$ ) para os seis cultivares estudados. 
Na Tabela 7 observa-se que, na ausência de alumínio os cultivares C525, C135 e C125 apresentaram extrações de nitrogênio pelas folhas significativamente maiores que os demais. Com o aumento do nível de alumínio da solução, o cultivar C525 apresentou extrações de nitrogênio pelas folhas entre as maiores, até $50 \mathrm{mg} . \mathrm{L}^{\mathbf{- 1}}$.

A Tabela 8 apresenta a extração de nitrogênio pelas raízes (mg.planta-1) em função dos níveis de alumínio estudados (mg.L ${ }^{\mathbf{- 1}}$ ), dentro de cada cultivar. Observa-se que dos cultivares estudados, somente C525, C135 e C125 apresentaram redução na extração de nitrogênio pelas raizes com o aumento da concentração de alumínio da solução, apresentando entretanto comportamentos diferentes em relação aos níveis de alumínio. Assim, o cultivar C125 não apresentou redução significativa na extração de nitrogênio pelas raízes com até 20 mg.L-1 de alumínio na solução; o cultivar C135 não apresentou redução na extração de nitrogênio pelas raízes até $10 \mathrm{mg} \cdot \mathrm{L}^{-1}$, não apresentando uma queda significativa nos demais níveis. O cultivar C525 apresentou redução progressiva na extração de nitrogênio pelas raizes, em função dos níveis de alumínio da solução.

O comportamento da extração de nitrogênio pelas raízes em cada cultivar, em função dos níveis de alumínio aplicados, é apresentado na Figura 5, onde são representadas as equações de regressão entre a extração de nitrogênio pelas raizes (mg.planta-1) e as doses de alumínio (mg.L ${ }^{-1}$ ), para os seis cultivares estudados. Assim, todas as regressões representam a redução da extração pelas raizes em função dos níveis de alumínio, porém os cultivares C125, C701 e C805 apresentaram reduções representadas por equações lineares, enquanto os demais cultivares apresentaram reduções representadas por equações quadráticas, com mínimos em 33,5; 40,8 e 50,7 mg.L-1 para os cultivares C425, C135 e C525 respectivamente. Observou-se que o sistema radicular do cultivar $\mathrm{C} 525$ extraiu mais nitrogênio que o dos demais cultivares, até o nível $30 \mathrm{mg} . \mathrm{L}^{-1}$ de alumínio na solução nutritiva.

$\mathrm{Na}$ Tabela 8 observa-se que, na ausência de alumínio, os cultivares C525 e C135 apresentaram extrações de nitrogênio pelas raizes significativamente maiores que os dos cultivares $\mathrm{C} 425$ e C701, não diferindo estatisticamente das extrações dos demais cultivares. O nivel $20 \mathrm{mg} . \mathrm{L}^{-1}$ foi o que melhor diferenciou os cultivares quanto ao seu comportamento em relação ao alumínio. Assim, nesse 
Tabela 8. Extração de nitrogênio pelas raízes (mg.planta ${ }^{-1}$ ) em função dos níveis de alumínio estudados (mg. $\left.L^{-1}\right)$, dentro de cada cultivar (médias de quatro repetiçōes).

\begin{tabular}{||c|c|c|c|c|c|c|c||}
\hline \multirow{2}{*}{ Cultivares } & \multicolumn{7}{|c|}{ Alumínio (mg.L-1) } \\
\cline { 2 - 8 } & 0 & 10 & 20 & 30 & 40 & 50 \\
\hline 525 & $178,51 \mathrm{Aa}$ & $118,40 \mathrm{Ab}$ & $87,71 \mathrm{ABbc}$ & $78,89 \mathrm{Abc}$ & $72,34 \mathrm{ABbc}$ & $44,03 \mathrm{Ac}$ & $96,65 \mathrm{~A}$ \\
\hline 135 & $174,12 \mathrm{Aa}$ & $102,53 \mathrm{ABab}$ & $72,45 \mathrm{ABbc}$ & $64,82 \mathrm{Abc}$ & $56,92 \mathrm{ABbc}$ & $46,76 \mathrm{Ac}$ & $86,27 \mathrm{AB}$ \\
\hline 125 & $133,22 \mathrm{ABa}$ & $98,35 \mathrm{ABabc}$ & $106,74 \mathrm{Aab}$ & $58,01 \mathrm{Abc}$ & $43,72 \mathrm{ABc}$ & $53,88 \mathrm{Abc}$ & $82,32 \mathrm{AB}$ \\
\hline 805 & $97,10 \mathrm{BCa}$ & $94,11 \mathrm{ABa}$ & $85,32 \mathrm{ABa}$ & $61,44 \mathrm{Aa}$ & $81,11 \mathrm{Aa}$ & $59,77 \mathrm{Aa}$ & $79,81 \mathrm{~B}$ \\
\hline 701 & $68,84 \mathrm{Ca}$ & $71,37 \mathrm{ABa}$ & $38,22 \mathrm{Ba}$ & $41,89 \mathrm{Aa}$ & $24,60 \mathrm{Ba}$ & $29,11 \mathrm{Aa}$ & $45,67 \mathrm{C}$ \\
\hline 425 & $74,34 \mathrm{Ca}$ & $61,77 \mathrm{Ba}$ & $38,98 \mathrm{Ba}$ & $39,56 \mathrm{Aa}$ & $27,85 \mathrm{ABa}$ & $48,92 \mathrm{Aa}$ & $48,57 \mathrm{C}$ \\
\hline Médias & $121,02 \mathrm{a}$ & $91,09 \mathrm{~b}$ & $71,57 \mathrm{c}$ & $57,43 \mathrm{~cd}$ & $51,09 \mathrm{~d}$ & $47,08 \mathrm{~d}$ & 73,21 \\
\hline
\end{tabular}

- Médias seguidas por letras iguais, maiúsculas na vertical ou minúsculas na horizontal, não diferem entre si pelo teste de Tukey ao nivel de $5 \%$ de probabilidade. 


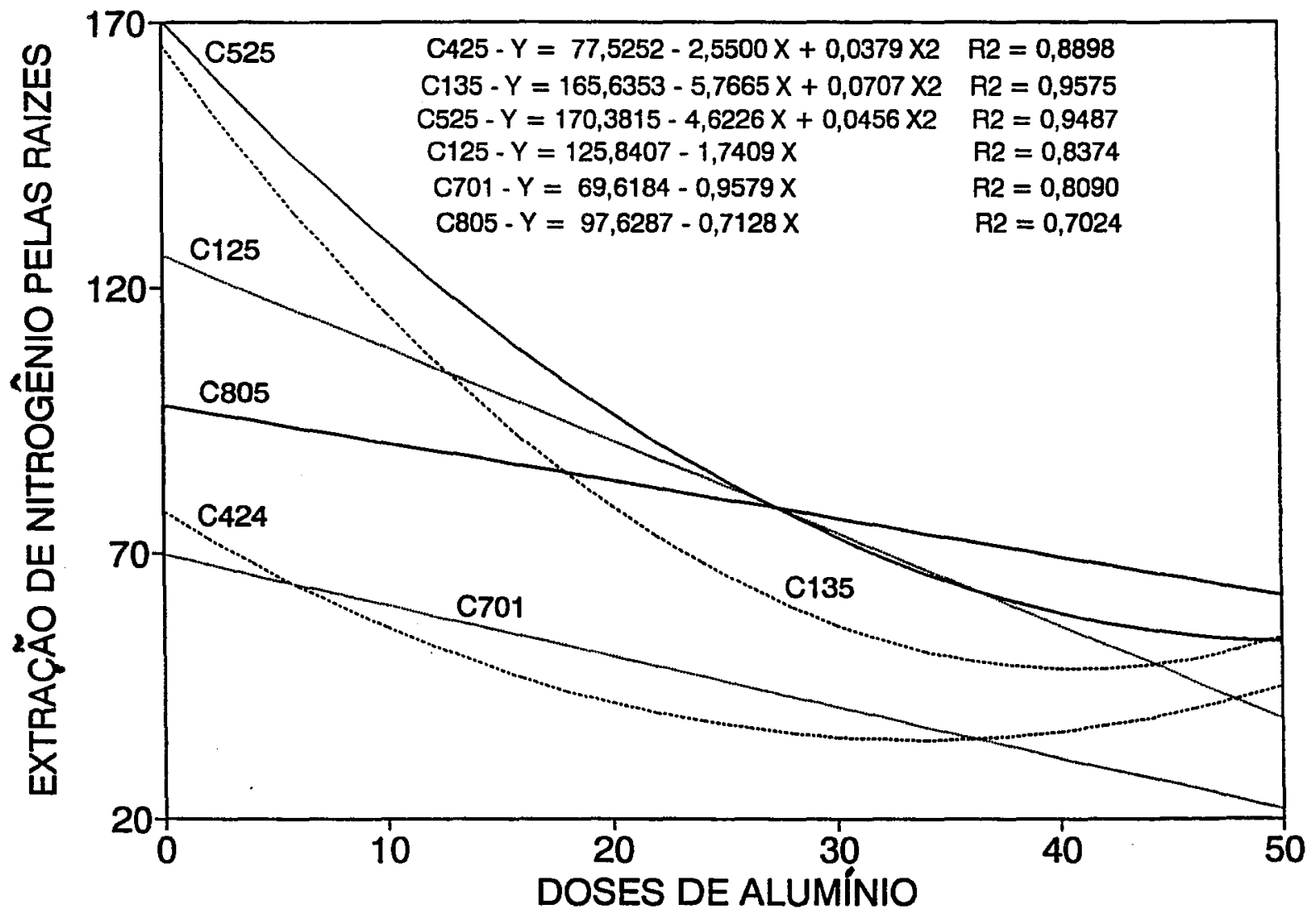

Figura 5. Regressões entre a extração de nitrogênio pelas raízes (g.planta-1) e os níveis de alumínio (mg. $\mathrm{L}^{\mathbf{- 1}}$ ) para os seis cultivares estudados. 
nível, o cultivar $\mathrm{C} 125$ apresentou a maior extração de nitrogênio pelas raízes, diferindo significativamente dos cultivares $\mathrm{C} 701$ e C425 e não diferindo dos demais cultivares.

A Tabela 9 apresenta a extração de nitrogênio pelos colmos (mg.planta-1) em função dos níveis de alumínio estudados (mg.L ${ }^{-1}$ ), dentro de cada cultivar. Observa-se que dos cultivares estudados, somente C525, C135 e C125 apresentaram redução na extração de nitrogênio pelos colmos, com o aumento da concentração de alumínio da solução, apresentando comportamentos diversos em relação aos níveis de alumínio. Assim, o cultivar C125 praticamente não apresentou redução significativa na extração pelos colmos com até $20 \mathrm{mg} . \mathrm{L}^{-1}$ de alumínio na solução; os cultivares C525 e C135 não apresentaram redução na extração de nitrogênio pelos colmos até $10 \mathrm{mg} . \mathrm{L}^{-1}$, sendo que enquanto o primeiro não apresentava uma queda significativa nos demais níveis, o segundo apresentou redução significativa da extração nas mesmas condições. Os cultivares C805, C701 e C425 não apresentaram redução significativa na extração de nitrogênio pelos colmos.

O comportamento da extração de nitrogênio pelos colmos em cada cultivar, em função dos níveis de alumínio aplicados, é apresentado na Figura 6, onde são representadas as equações de regressão entre a extração de nitrogênio pelos colmos (mg.planta-1) e os níveis de alumínio (mg. $\mathrm{L}^{-1}$ ), para quatro dos seis cultivares estudados, uma vez que os cultivares C805 e C701 não apresentaram redução na extração pelos colmos, em função dos niveis de alumínio. Assim, todas as regressões representam a redução da extração de nitrogênio pelos colmos, em função dos níveis de alumínio, porém os cultivares C135, C125 e C701 apresentaram reduções representadas por equações lineares, enquanto o cultivar C525 apresentou redução representada por uma equação quadrática, com mínimo em 45,7 mg.L-1 de alumínio.

Na Tabela 9 observa-se que, na ausência de alumínio, os cultivares C525 e C135 apresentaram extrações de nitrogênio pelos colmos significativamente maiores que os demais. Com o aumento do nível de alumínio da solução, foi o cultivar C525 que apresentou as maiores extrações de nitrogênio até $20 \mathrm{mg} . \mathrm{L}^{-1}$, quando não diferiu dos demais, tornando-se semelhante às extrações dos outros cultivares nos níveis maiores. 
Tabela 9. Extração de nitrogênio pelos colmos (mg.planta ${ }^{-1}$ ) em função dos níveis de alumínio estudados (mg. $\mathrm{L}^{-1}$ ), dentro de cada cultivar (médias de quatro repetições).

\begin{tabular}{|c|c|c|c|c|c|c|c|}
\hline \multirow[t]{2}{*}{ Cultivares } & \multicolumn{6}{|c|}{ Alumínio (mg. $\mathrm{L}^{-1}$ ) } & \multirow[t]{2}{*}{ Médias } \\
\hline & 0 & 10 & 20 & 30 & 40 & 50 & \\
\hline 525 & $223,42 \mathrm{Aa}$ & $203,27 \mathrm{Aa}$ & $89,21 \mathrm{ABb}$ & $75,51 \mathrm{Ab}$ & $56,24 \mathrm{ABb}$ & $58,85 \mathrm{ABb}$ & $117,75 \mathrm{~A}$ \\
\hline 135 & $182,04 \mathrm{ABa}$ & 145,30 Bab & $120,51 \mathrm{Ab}$ & $62,65 \mathrm{ABc}$ & $42,87 \mathrm{ABc}$ & $39,13 \mathrm{ABCc}$ & $98,75 \mathrm{~A}$ \\
\hline 125 & $151,42 \mathrm{Ba}$ & 116,49 Babc & 124,44 Aab & 73,94 ABbc & $62,68 \mathrm{Ac}$ & $84,49 \mathrm{Abc}$ & $102,24 \mathrm{~A}$ \\
\hline 805 & $58,55 \mathrm{Ca}$ & $36,12 \mathrm{Ca}$ & $43,69 \mathrm{BCa}$ & $27,65 \mathrm{ABa}$ & $51,82 \mathrm{ABa}$ & $41,26 \mathrm{ABCa}$ & $43,18 \mathrm{~B}$ \\
\hline 701 & $50,52 \mathrm{Ca}$ & $28,35 \mathrm{Ca}$ & $20,33 \mathrm{Ca}$ & $19,72 \mathrm{Ba}$ & $12,48 \mathrm{Ba}$ & $0,0 \mathrm{Ca}$ & $21,90 \mathrm{~B}$ \\
\hline 425 & $33,27 \mathrm{Ca}$ & $23,97 \mathrm{Ca}$ & $19,87 \mathrm{Ca}$ & $20,31 \mathrm{ABa}$ & $29,79 \mathrm{ABa}$ & $22,57 \mathrm{BCa}$ & $24,96 \mathrm{~B}$ \\
\hline Médias & 116,54 a & $92,25 \mathrm{~b}$ & $69,68 \mathrm{bc}$ & $46,63 \mathrm{~cd}$ & $42,64 \mathrm{~d}$ & $41,05 \mathrm{~d}$ & 68,13 \\
\hline
\end{tabular}

- Médias seguidas por letras iguais, maiúsculas na vertical ou minúsculas na horizontal, não diferem entre si pelo teste de Tukey ao nivel de $5 \%$ de probabilidade. 


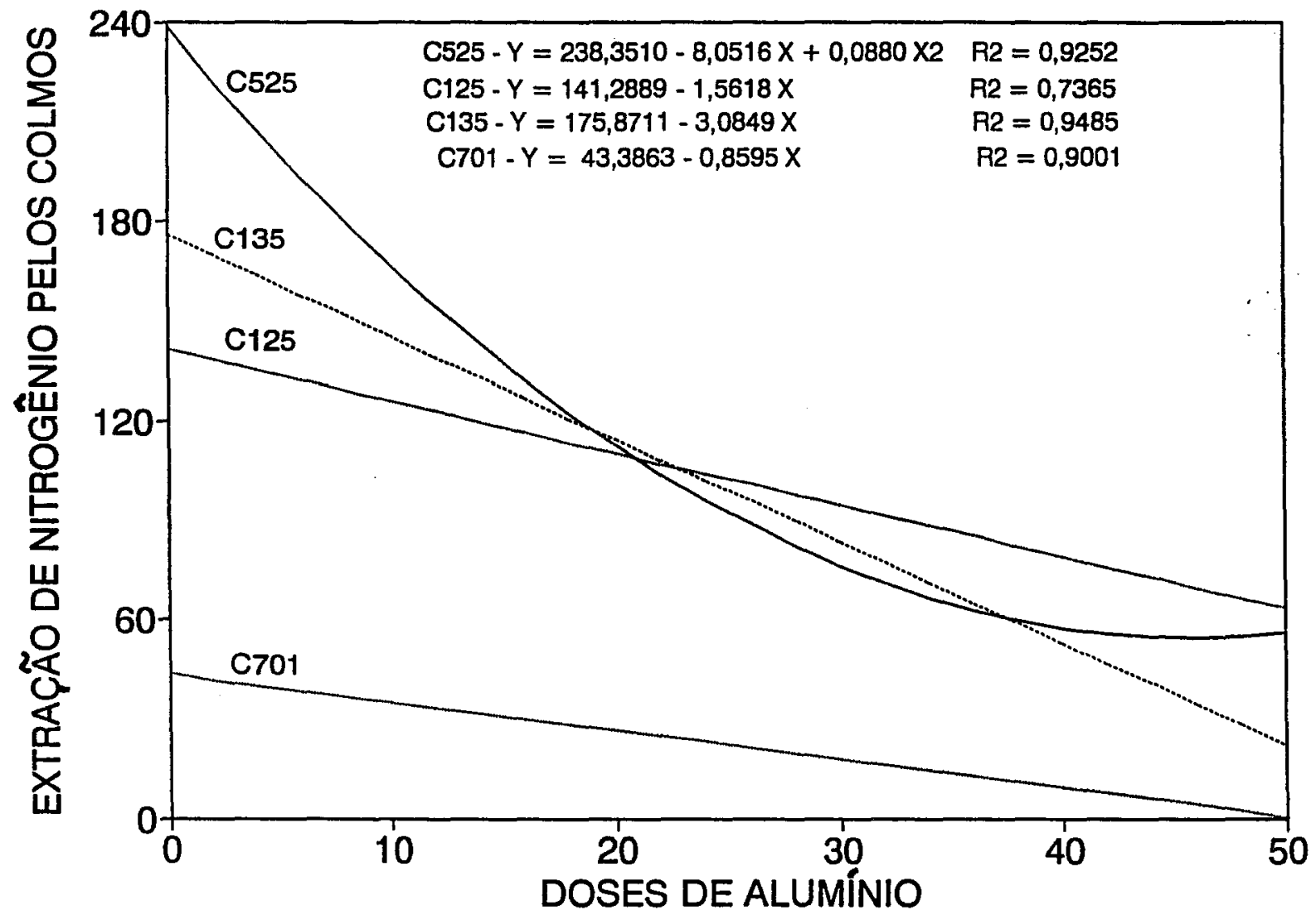

Figura 6. Regressões entre a extração de nitrogênio pelos colmos(g.planta-1) e os níveis de alumínio (mg.L $\mathbf{- 1}^{-1}$ ) para quatro dos seis cultivares estudados. 
A Tabela 10 apresenta a extração de nitrogênio (mg.planta-1) das partes amostradas dentro de cada cultivar, para os níveis 0 e $10 \mathrm{mg} . \mathrm{L}^{-1}$ de alumínio na solução. Observa-se que na ausência de alumínio, os cultivares já apresentavam comportamentos diferentes em relação à extração de nitrogênio pelas três partes amostradas. Assim, os cultivares C135, C125 e C701 apresentavam extrações de nitrogênio pelas folhas estatisticamente maiores que as outras duas partes, enquanto os cultivares C805 e C425 apresentavam extração pelas folhas e raizes superiores às dos colmos e o cultivar C525 apresentava a extração pelas folhas significativamente maior que a das raízes e esta que a dos colmos. Ainda na ausência de alumínio, quanto à extração de nitrogênio pelas folhas, os cultivares $\mathrm{C} 525, \mathrm{C} 135$ e C125 apresentaram valores significativamente maiores que os demais cultivares, dos quais a do cultivar $\mathrm{C} 425$ foi menor que a do cultivar C805; quanto à extração de nitrogênio pelas raízes, os cultivares C525, C135 e C125 diferiram dos demais, que não diferiram entre si; quanto à extração de nitrogênio pelos colmos, o cultivar C135 diferiu dos demais cultivares, exceto do cultivar C125 do qual não diferiu estatisticamente.

No nível 10 mg.L $\mathbf{~}^{-1}$ de alumínio, observa-se que os cultivares também apresentavam comportamentos diversos em relação à extração de nitrogênio pelas três partes amostradas. Assim, o cultivar C425 apresentava as três partes com extrações estatisticamente semelhantes, enquanto os cultivares C135 e C125 apresentavam extrações de nitrogênio pelas folhas superior à das demais partes, os cultivares C805 e C701 apresentavam a extração de nitrogênio pelas raizes semelhante às extrações pelas folhas e pelos colmos, embora elas fossem estatisticamente diferentes e para o cultivar C525 a extração pelas folhas foi significativamente maior que a dos colmos e esta que a das raízes. Ainda no nível $10 \mathrm{mg} . \mathrm{L}^{-1}$ de alumínio, quanto à extração de nitrogênio pelas folhas, o cultivar C525 apresentou valores significativamente maiores que os demais cultivares; quanto à extração pelas raízes, o cultivar C525 diferiu apenas do cultivar C425, não diferindo dos demais; quanto à extração de nitrogênio pelos colmos, o cultivar C525 diferiu dos demais cultivares.

A Tabela 11 apresenta a extração de nitrogênio (mg.planta-1) das partes amostradas dentro de cada cultivar, para os níveis 20 e $30 \mathrm{mg} . \mathrm{L}^{\mathbf{- 1}}$ de alumínio na solução. Observa-se que no nível $20 \mathrm{mg} . \mathrm{L}^{-1}$ de alumínio, os cultivares apresentaram comportamentos diferentes em relação à extração de 
Tabela 10: $\quad$ Extração de nitrogênio (mg.planta ${ }^{-1}$ ) em função das partes amostradas, dentro de cada cultivar, para os níveis 0 e $10 \mathrm{mg} \cdot \mathrm{L}^{-1}$ de alumínio (médias de quatro repetições).

\begin{tabular}{||c|c|c|c|c||}
\hline \multirow{2}{*}{ Cultivares } & \multicolumn{5}{|c|}{ Nível 0 de Alumínio } \\
\cline { 2 - 5 } & Folhas & Raízes & Colmos & Médias \\
\hline 525 & $259,56 \mathrm{Aa}$ & $178,51 \mathrm{Ab}$ & $50,52 \mathrm{Cc}$ & $220,50 \mathrm{~A}$ \\
\hline 135 & $269,07 \mathrm{Aa}$ & $174,12 \mathrm{Ab}$ & $182,04 \mathrm{Ab}$ & $208,41 \mathrm{AB}$ \\
\hline 125 & $216,10 \mathrm{Aa}$ & $133,21 \mathrm{ABb}$ & $151,42 \mathrm{ABb}$ & $167,21 \mathrm{~B}$ \\
\hline 805 & $151,01 \mathrm{Ba}$ & $97,10 \mathrm{BCab}$ & $58,55 \mathrm{BCb}$ & $102,22 \mathrm{C}$ \\
\hline 701 & $130,93 \mathrm{BCa}$ & $68,84 \mathrm{Cb}$ & $50,52 \mathrm{Cb}$ & $83,43 \mathrm{C}$ \\
\hline 425 & $94,80 \mathrm{Ca}$ & $74,34 \mathrm{Cab}$ & $33,27 \mathrm{Cb}$ & $67,50 \mathrm{C}$ \\
\hline Médias & $187,06 \mathrm{a}$ & $121,02 \mathrm{~b}$ & $116,54 \mathrm{~b}$ & 141,54 \\
\hline & & Nível $10 \mathrm{de} \mathrm{Alumíni}$ & & \\
\hline 525 & $328,26 \mathrm{Aa}$ & $118,40 \mathrm{Ac}$ & $203,27 \mathrm{Ab}$ & $216,64 \mathrm{~A}$ \\
\hline 135 & $202,05 \mathrm{Ba}$ & $102,53 \mathrm{ABb}$ & $145,30 \mathrm{Bb}$ & $149,96 \mathrm{~B}$ \\
\hline 125 & $178,77 \mathrm{Ba}$ & $98,35 \mathrm{ABb}$ & $116,49 \mathrm{Bb}$ & $131,20 \mathrm{~B}$ \\
\hline 805 & $88,32 \mathrm{Cab}$ & $94,11 \mathrm{ABa}$ & $36,12 \mathrm{Cb}$ & $72,85 \mathrm{C}$ \\
\hline 701 & $92,94 \mathrm{Ca}$ & $71,37 \mathrm{ABab}$ & $28,35 \mathrm{Cb}$ & $64,22 \mathrm{C}$ \\
\hline 425 & $68,20 \mathrm{Ca}$ & $61,77 \mathrm{Ba}$ & $23,97 \mathrm{Ca}$ & $51,31 \mathrm{C}$ \\
\hline Médias & $159,76 \mathrm{a}$ & $92,25 \mathrm{~b}$ & $91,09 \mathrm{~b}$ & 114,37 \\
\hline \hline
\end{tabular}

- Médias seguidas por letras iguais, maiúsculas na vertical ou minúsculas na horizontal, dentro de cada nível de alumínio, não diferem entre si pelo teste de Tukey ao nivel de $5 \%$ de probabilidade 
Tabela 11: Extração de nitrogênio (mg.planta $\left.{ }^{-1}\right)$ em função das partes amostradas, dentro de cada cultivar, para os níveis 20 e $30 \mathrm{mg} \cdot \mathrm{L}^{-1}$ de alumínio (médias de quatro repetições).

\begin{tabular}{||c|c|c|c|c||}
\hline \hline \multirow{2}{*}{ Cultivares } & \multicolumn{5}{|c|}{ Pível 20 de Alumínio } \\
\cline { 2 - 5 } & Folhas & Raízes & Colmos & Médias \\
\hline 525 & $138,10 \mathrm{ABa}$ & $87,71 \mathrm{ABa}$ & $89,21 \mathrm{ABa}$ & $105,30 \mathrm{~B}$ \\
\hline 135 & $135,91 \mathrm{ABa}$ & $72,45 \mathrm{ABb}$ & $120,51 \mathrm{Aab}$ & $109,62 \mathrm{~B}$ \\
\hline 125 & $188,80 \mathrm{Aa}$ & $106,73 \mathrm{Ab}$ & $124,44 \mathrm{Ab}$ & $139,99 \mathrm{~A}$ \\
\hline 805 & $92,37 \mathrm{BCa}$ & $85,31 \mathrm{ABa}$ & $43,69 \mathrm{BCa}$ & $73,79 \mathrm{C}$ \\
\hline 701 & $56,11 \mathrm{Ca}$ & $38,22 \mathrm{Ba}$ & $20,34 \mathrm{Ca}$ & $38,22 \mathrm{D}$ \\
\hline 425 & $51,87 \mathrm{Ca}$ & $38,98 \mathrm{Ba}$ & $19,87 \mathrm{Ca}$ & $36,91 \mathrm{D}$ \\
\hline Médias & $110,67 \mathrm{a}$ & $71,60 \mathrm{~b}$ & $69,68 \mathrm{~b}$ & 83,97 \\
\hline & & Nível $30 \mathrm{de} \mathrm{Alumínio}$ & \\
\hline 525 & $115,79 \mathrm{Aa}$ & $78,90 \mathrm{Aa}$ & $75,51 \mathrm{Aa}$ & $90,07 \mathrm{~A}$ \\
\hline 135 & $112,73 \mathrm{Aa}$ & $64,82 \mathrm{Aa}$ & $62,65 \mathrm{Aa}$ & $80,06 \mathrm{AB}$ \\
\hline 125 & $89,59 \mathrm{ABa}$ & $58,01 \mathrm{Aa}$ & $73,94 \mathrm{Aa}$ & $73,85 \mathrm{AB}$ \\
\hline 805 & $100,43 \mathrm{ABa}$ & $61,44 \mathrm{Aab}$ & $27,65 \mathrm{Ab}$ & $63,17 \mathrm{~B}$ \\
\hline 701 & $49,03 \mathrm{Ba}$ & $41,90 \mathrm{Aa}$ & $19,72 \mathrm{Aa}$ & $36,88 \mathrm{C}$ \\
\hline 425 & $49,89 \mathrm{Ba}$ & $39,56 \mathrm{Aa}$ & $20,31 \mathrm{Aa}$ & $36,59 \mathrm{C}$ \\
\hline Médias & $86,24 \mathrm{a}$ & $57,43 \mathrm{~b}$ & $46,63 \mathrm{~b}$ & 63,44 \\
\hline \hline
\end{tabular}

- Médias seguidas por letras iguais, maiúsculas na vertical ou minúsculas na horizontal, dentro de cada nível de alumínio, não diferem entre si pelo teste de Tukey ao nivel de $5 \%$ de probabilidade 
nitrogênio pelas três partes amostradas. Assim, os cultivares C525, C805, C701 e C425 apresentaram as extrações de nitrogênio pelas três partes estatisticamente semelhantes, enquanto o cultivar C135 apresentou extração pelas folhas maior que a das raízes e estas não diferindo das extrações dos colmos e o cultivar C125 que apresentava a extração pelas folhas significativamente maior que a das duas outras partes. Ainda no nível $20 \mathrm{mg} \cdot \mathrm{L}^{\mathbf{- 1}}$ de alumínio, quanto à extração de nitrogênio pelas folhas, os cultivares C525, C135 e C125 não diferiram entre si, sendo que os dois últimos foram semelhantes ao cultivar C805, que não diferiu dos demais; quanto à extração de nitrogênio pelas raízes, os cultivares C525, C135, C125 e C805 não diferiram entre si, sendo que somente o cultivar C125 diferiu dos demais; quanto à extração de nitrogênio pelos colmos, os cultivares C135 e C125 diferiram dos cultivares C701 e C425 e foram semelhantes ao cultivar C525.

No nível $30 \mathrm{mg} \cdot \mathrm{L}^{\mathbf{- 1}}$ de alumínio, observa-se que os cultivares também apresentavam comportamentos diversos em relação à extração de nitrogênio pelas três partes amostradas. Assim, os cultivares C525, C135, C125, C701 e C425 apresentaram as três partes com extrações estatisticamente semelhantes, enquanto o cultivar C805 apresentou extrações de nitrogênio pelas folhas superior à dos colmos. Ainda no nível $30 \mathrm{mg}$. $\mathrm{L}^{\mathbf{- 1}}$ de alumínio, quanto à extração de nitrogênio pelas folhas, os cultivares C525 e C135 apresentaram valores significativamente maiores que os cultivares $C 701$ e C425, não diferindo dos demais; quanto à extração pelas raízes e pelos colmos, os cultivares não diferiram entre si.

A Tabela 12 apresenta a extração de nitrogênio (mg.planta-1) das partes amostradas dentro de cada cultivar, para os níveis 40 e $50 \mathrm{mg} . \mathrm{L}^{-1}$ de alumínio na solução. Observa-se que no nível $40 \mathrm{mg} . \mathrm{L}^{-1}$ de alumínio, os cultivares não apresentaram comportamentos diferentes em relação à extração de nitrogênio pelas três partes amostradas, pois os cultivares não diferiram entre si quanto às extrações de nitrogênio pelas três partes amostradas que foram estatisticamente semelhantes. Ainda no nível $40 \mathrm{mg} . \mathrm{L}^{-1}$ de alumínio, quanto à extração de nitrogênio pelas folhas, o cultivar C805 diferiu dos cultivares C701 e C425, não diferindo dos demais; quanto à extração de nitrogênio pelas raízes, o cultivar C805 diferiu apenas do cultivar C701 não diferindo dos demais; quanto à extração de nitrogênio pelos colmos, os cultivares não diferiram entre si. 
Tabela 12: Extração de nitrogênio (mg.planta ${ }^{-1}$ ) em função das partes amostradas, dentro de cada cultivar, para os níveis 40 e $50 \mathrm{mg} . \mathrm{L}^{-1}$ de alumínio (médias de quatro repetições).

\begin{tabular}{||c|c|c|c|c||}
\hline \multirow{2}{*}{ Cultivares } & \multicolumn{5}{|c|}{ Nível 40 de Alumínio } \\
\cline { 2 - 5 } & Folhas & Raízes & Colmos & Médias \\
\hline 525 & $71,13 \mathrm{ABa}$ & $72,34 \mathrm{ABa}$ & $56,24 \mathrm{Aa}$ & $66,57 \mathrm{AB}$ \\
\hline 135 & $55,85 \mathrm{ABa}$ & $56,92 \mathrm{ABa}$ & $42,87 \mathrm{Aa}$ & $51,88 \mathrm{C}$ \\
\hline 125 & $54,67 \mathrm{ABa}$ & $43,72 \mathrm{ABa}$ & $62,68 \mathrm{Aa}$ & $53,69 \mathrm{BC}$ \\
\hline 805 & $97,21 \mathrm{Aa}$ & $81,11 \mathrm{Aa}$ & $51,82 \mathrm{Aa}$ & $76,71 \mathrm{~A}$ \\
\hline 701 & $40,76 \mathrm{Ba}$ & $24,60 \mathrm{Ba}$ & $12,48 \mathrm{Aa}$ & $25,94 \mathrm{D}$ \\
\hline 425 & $35,10 \mathrm{Ba}$ & $27,85 \mathrm{ABa}$ & $29,79 \mathrm{Aa}$ & $31,21 \mathrm{D}$ \\
\hline Médias & $59,27 \mathrm{a}$ & $51,09 \mathrm{a}$ & $42,64 \mathrm{~b}$ & 51,00 \\
\hline & & Nível $50 \mathrm{de} \mathrm{Aluminio}$ & \\
\hline 525 & $39,02 \mathrm{Aa}$ & $44,03 \mathrm{Aa}$ & $58,85 \mathrm{ABa}$ & $47,30 \mathrm{AB}$ \\
\hline 135 & $42,67 \mathrm{Aa}$ & $46,76 \mathrm{Aa}$ & $39,13 \mathrm{ABCa}$ & $42,85 \mathrm{BC}$ \\
\hline 125 & $46,32 \mathrm{Aa}$ & $53,87 \mathrm{Aa}$ & $84,49 \mathrm{Aa}$ & $61,56 \mathrm{~A}$ \\
\hline 805 & $79,29 \mathrm{Aa}$ & $59,77 \mathrm{Aa}$ & $41,26 \mathrm{ABCa}$ & $60,11 \mathrm{~A}$ \\
\hline 701 & $60,84 \mathrm{Aa}$ & $29,11 \mathrm{Aab}$ & $0,0 \mathrm{Cb}$ & $29,98 \mathrm{C}$ \\
\hline 425 & $50,47 \mathrm{Aa}$ & $48,92 \mathrm{Aa}$ & $22,57 \mathrm{BCa}$ & $40,65 \mathrm{BC}$ \\
\hline Médias & $53,10 \mathrm{a}$ & $47,08 \mathrm{ab}$ & $41,05 \mathrm{~b}$ & 47,07 \\
\hline \hline
\end{tabular}

- Médias seguidas por letras iguais, maiúsculas na vertical ou minúsculas na horizontal, dentro de cada nível de alumínio, não diferem entre si pelo teste de Tukey ao nivel de $5 \%$ de probabilidade 
No nível 50 mg.L $\mathrm{L}^{\mathbf{- 1}}$ de alumínio, observa-se que os cultivares apresentaram comportamentos diversos em relação à extração de nitrogênio pelas três partes amostradas. Assim, o cultivar C701 apresentou a extração pelas folhas estatisticamente maior que a dos colmos, enquanto os demais cultivares apresentaram extrações semelhantes pelas três partes amostradas. Ainda no nível $50 \mathrm{mg} . \mathrm{L}^{-1}$ de alumínio, quanto à extração de nitrogênio pelas folhas e pelas raízes, os cultivares não diferiram significativamente entre si; quanto à extração pelos colmos, o cultivar C125 diferiu dos cultivares C701 e C425, não diferindo dos demais.

\subsection{Extração de fósforo}

A Tabela 13 apresenta a extração de fósforo pelas folhas (mg. planta-1) em função dos níveis de alumínio estudados (mg.L-1), dentro de cada cultivar. Observa-se que os cultivares C525, C135 e C125 apresentaram redução na extração de fósforo pelas folhas com o aumento da concentração de alumínio da solução, o mesmo não sendo observado para os cultivares C805, C701 e C425, que não diferiram estatisticamente em função dos níveis de alumínio. Assim, os cultivares C805, C701 e C425, não apresentaram estatisticamente, reduções na extração de fósforo pelas folhas com até $50 \mathrm{mg} . \mathrm{L}^{-1}$ de alumínio na solução. Os cultivares $\mathrm{C} 135$ e C125 não apresentaram redução significativa na extração de fósforo pelas folhas a partir de $10 \mathrm{mg} . \mathrm{L}^{\mathbf{- 1}} \mathrm{de}$ alumínio.

O comportamento da extração de fósforo pelas folhas em cada cultivar, em função dos níveis de alumínio aplicados, é apresentado na Figura 7, onde são representadas as equações de regressão entre a extração de fósforo pelas folhas (mg.planta-1) e as doses de alumínio (mg.L ${ }^{-1}$ ), para três dos seis cultivares estudados, uma vez que os cultivares C805, C701 e C425 não apresentaram redução na extração pelos colmos, em função dos níveis de alumínio. Assim, todas as regressões representam a redução da extração de fósforo pelas folhas em função dos níveis de alumínio, porém os cultivares C525 e C125 apresentaram reduções representadas por equações lineares, enquanto o cultivar C135 apresentou redução representada por equação quadrática, com mínimo em 43,8 mg.L ${ }^{-1}$ de alumínio. 
Tabela 13. Extração de fósforo pelas folhas (mg.planta ${ }^{-1}$ ) em função dos níveis de alumínio estudados (mg. $\left.\mathrm{L}^{-1}\right)$, dentro de cada cultivar (médias de quatro repetições).

\begin{tabular}{|c|c|c|c|c|c|c|c|}
\hline \multirow[t]{2}{*}{ Cultivares } & \multicolumn{6}{|c|}{ Alumínio (mg. $\mathrm{L}^{-1}$ ) } & \multirow[t]{2}{*}{ Médias } \\
\hline & 0 & 10 & 20 & 30 & 40 & 50 & \\
\hline 525 & $51,70 \mathrm{Ba}$ & $54,37 \mathrm{Aa}$ & $26,95 \mathrm{Ab}$ & $25,16 \mathrm{Abc}$ & 13,46 Acd & 7,29 Ad & $29,82 \mathrm{~A}$ \\
\hline 135 & $71,74 \mathrm{Aa}$ & $37,41 \mathrm{Bb}$ & $27,18 \mathrm{Abc}$ & $15,04 \mathrm{ABcd}$ & $6,81 \mathrm{Ad}$ & 7,11 Ad & $27,55 \mathrm{~A}$ \\
\hline 125 & $53,25 \mathrm{Ba}$ & $39,38 \mathrm{Bb}$ & $39,84 \mathrm{Ab}$ & $16,82 \mathrm{ABc}$ & $10,09 \mathrm{Ac}$ & $9,56 \mathrm{Ac}$ & $28,16 \mathrm{~A}$ \\
\hline 805 & $20,79 \mathrm{Ca}$ & $8,80 \mathrm{Ca}$ & $8,22 \mathrm{Ba}$ & $10,27 \mathrm{Ba}$ & $8,74 \mathrm{Aa}$ & $8,77 \mathrm{Aa}$ & $10,93 \mathrm{~B}$ \\
\hline 701 & $13,34 \mathrm{Ca}$ & $9,14 \mathrm{Ca}$ & $4,67 \mathrm{Ba}$ & $4,98 \mathrm{Ba}$ & 3,54 Aa & $6,25 \mathrm{Aa}$ & $6,99 \mathrm{~B}$ \\
\hline 425 & $14,34 \mathrm{Ca}$ & 6,77 Ca & $4,66 \mathrm{Ba}$ & $6,15 \mathrm{Ba}$ & $3,42 \mathrm{Aa}$ & $6,23 \mathrm{Aa}$ & $6,93 \mathrm{~B}$ \\
\hline Médias & $37,53 \mathrm{a}$ & $25,98 \mathrm{~b}$ & $18,59 \mathrm{c}$ & $13,07 \mathrm{~cd}$ & $7,68 \mathrm{~d}$ & $7,54 \mathrm{~d}$ & 18,40 \\
\hline
\end{tabular}

- Médias seguidas por letras iguais, maiúsculas na vertical ou minúsculas na horizontal, não diferem entre si pelo teste de Tukey ao nivel de $5 \%$ de probabilidade. 


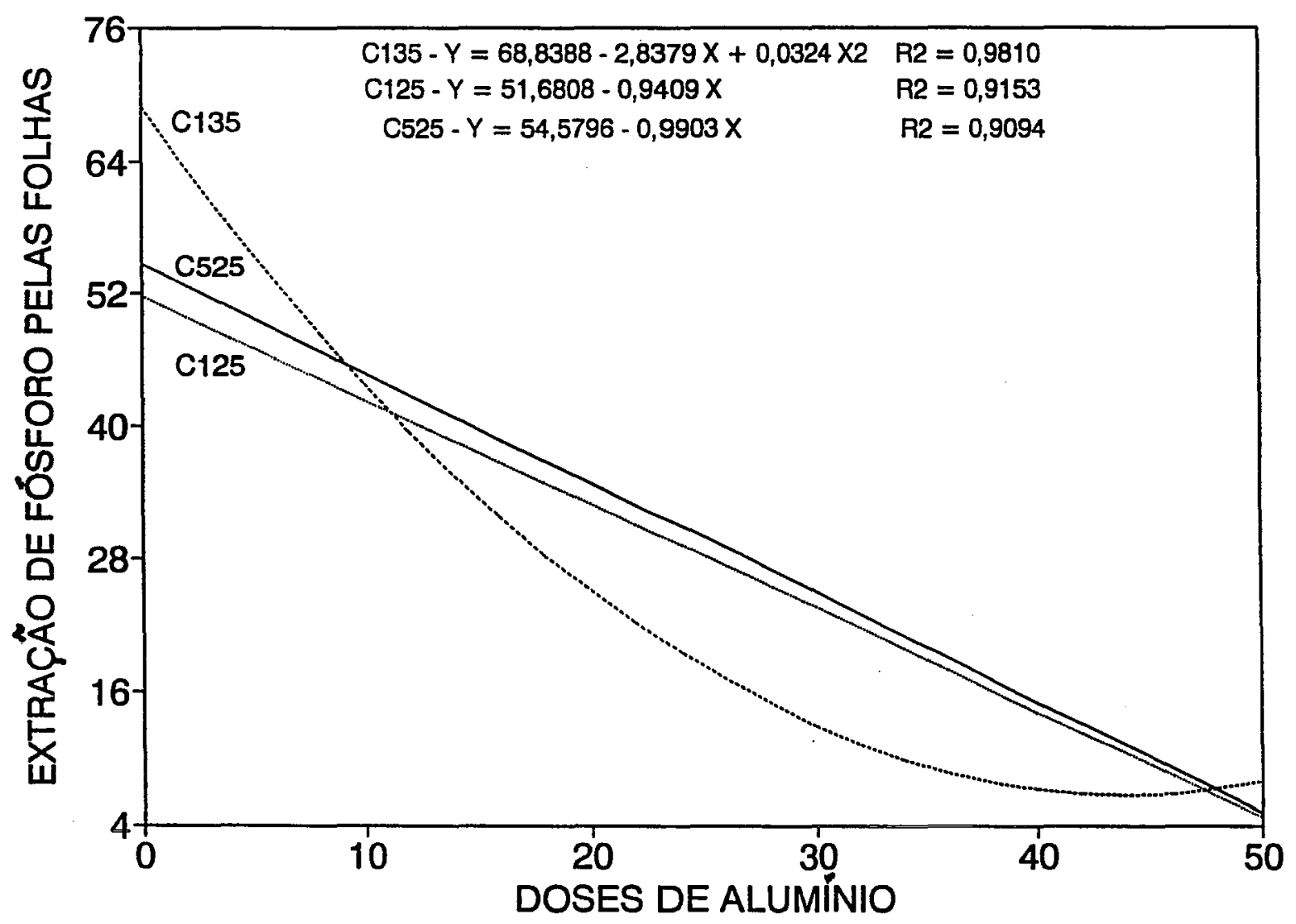

Figura 7. Regressões entre a extração de fósforo pelas folhas (g.planta-1) e os níveis de aluminio (mg.L $\mathrm{L}^{\mathbf{- 1}}$ ) para três dos seis cultivares estudados. 
$\mathrm{Na}$ Tabela 13 observa-se que, na ausência de alumínio o cultivar C135 diferiu dos demais cultivares estudados. Com o aumento do nível de alumínio da solução, os demais cultivares começaram a apresentar diferenças, sendo o nível $20 \mathrm{mg} . \mathrm{L}^{-1}$ que possibilitou a melhor separação dos cultivares quanto à toxidez por alumínio

A Tabela 14 apresenta a extração de fósforo pelas raízes (mg. planta $^{-1}$ ) em função dos níveis de alumínio estudados (mg.L-1), dentro de cada cultivar. Observa-se que dos cultivares estudados, somente os cultivares C525, C135 e C125 apresentaram redução na extração de fósforo pelas raízes com o aumento da concentração de alumínio da solução, apresentando entretanto redução significativa na extração de fósforo pelas raízes somente no nível 10 mg.L-1 de alumínio na solução.

O comportamento da extração de fósforo pelas raízes em cada cultivar, em função dos níveis de alumínio aplicados, é apresentado na Figura 8, onde são representadas as equações de regressão entre a extração de fósforo pelas raizes (mg.planta-1) e as doses de alumínio (mg.L-1), para três dos seis cultivares estudados, uma vez que os cultivares C805, C701 e C425 não apresentaram redução na extração pelos colmos, em função dos níveis de alumínio. Assim, todas as regressões representam a redução da extração pelas raízes em função dos niveis de alumínio, porém os cultivares C525 e C135 apresentaram reduções representadas por equações lineares, enquanto o cultivar $\mathrm{C} 125$ apresentou redução representada por equação quadrática, com mínimo em $33,8 \mathrm{mg} . \mathrm{L}^{\mathbf{- 1}}$ de alumínio. Observou-se que o sistema radicular do cultivar C525 extraiu mais fósforo que o dos demais cultivares, do nível 10 ao nível $40 \mathrm{mg} . \mathrm{L}^{-1}$ de alumínio na solução nutritiva.

Na Tabela 14 observa-se que, na ausência de alumínio, os cultivares C525, C135 e C125 apresentaram extrações de fósforo pelas raizes significativamente maiores que os demais cultivares. Nos demais níveis, exceto $20 \mathrm{mg} . \mathrm{L}^{-1}$ de alumínio, o cultivar C701 foi significativamente menor que os demais.

A Tabela 15 apresenta a extração de fósforo pelos colmos (mg.planta ${ }^{-1}$ ) em função dos níveis de alumínio estudados (mg.L $\mathbf{- 1}$ ), dentro de cada cultivar. Observa-se que dos cultivares estudados, somente C525, C135 e C125 apresentaram redução na extração de fósforo pelos colmos, com o aumento da concentração de alumínio da solução, apresentando comportamentos diversos 
Tabela 14. Extração de fósforo pelas raízes (mg.planta $\left.{ }^{-1}\right)$ em função dos níveis de alumínio estudados (mg. $\left.\mathrm{L}^{-1}\right)$, dentro de cada cultivar (médias de quatro repetições).

\begin{tabular}{|c|c|c|c|c|c|c|c|}
\hline \multirow[t]{2}{*}{ Cultivares } & \multicolumn{6}{|c|}{ Alumínio (mg. $\mathrm{L}^{-1}$ ) } & \multirow[t]{2}{*}{ Médias } \\
\hline & 0 & 10 & 20 & 30 & 40 & 50 & \\
\hline 525 & $45,62 \mathrm{Aa}$ & $21,01 \mathrm{ABb}$ & $23,78 \mathrm{Ab}$ & $28,50 \mathrm{Ab}$ & $20,56 \mathrm{ABb}$ & $16,10 \mathrm{ABb}$ & $25,93 \mathrm{~A}$ \\
\hline 135 & $38,10 \mathrm{Aa}$ & $22,81 \mathrm{ABb}$ & $18,28 \mathrm{Ab}$ & $24,69 \mathrm{Aab}$ & $21,13 \mathrm{Ab}$ & $13,26 \mathrm{ABb}$ & $23,04 \mathrm{~A}$ \\
\hline 125 & $42,48 \mathrm{Aa}$ & $24,46 \mathrm{Ab}$ & $21,28 \mathrm{Ab}$ & $24,04 \mathrm{Ab}$ & $14,98 \mathrm{ABb}$ & $23,52 \mathrm{Ab}$ & $25,13 \mathrm{~A}$ \\
\hline 805 & $16,88 \mathrm{Ba}$ & $23,91 \mathrm{ABa}$ & $21,66 \mathrm{Aa}$ & $21,38 \mathrm{ABa}$ & $22,38 \mathrm{Aa}$ & $16,63 \mathrm{ABa}$ & $20,47 \mathrm{~A}$ \\
\hline 701 & $13,38 \mathrm{Ba}$ & $10,91 \mathrm{Ba}$ & $11,49 \mathrm{Aa}$ & $9,33 \mathrm{Ba}$ & $7,45 \mathrm{Ba}$ & $10,20 \mathrm{Ba}$ & $10,46 \mathrm{~B}$ \\
\hline 425 & $13,10 \mathrm{Ba}$ & $13,53 \mathrm{ABa}$ & $14,46 \mathrm{Aa}$ & $17,41 \mathrm{ABa}$ & $9,34 \mathrm{ABa}$ & $15,73 \mathrm{ABa}$ & 13,93 B \\
\hline Médias & $28,26 \mathrm{a}$ & $19,44 \mathrm{~b}$ & $18,49 \mathrm{~b}$ & $20,89 \mathrm{~b}$ & $15,97 \mathrm{~b}$ & $15,91 \mathrm{~b}$ & 19,83 \\
\hline
\end{tabular}

- Médias seguidas por letras iguais, maiúsculas na vertical ou minúsculas na horizontal, não diferem entre si pelo teste de Tukey ao nível de $5 \%$ de probabilidade. 


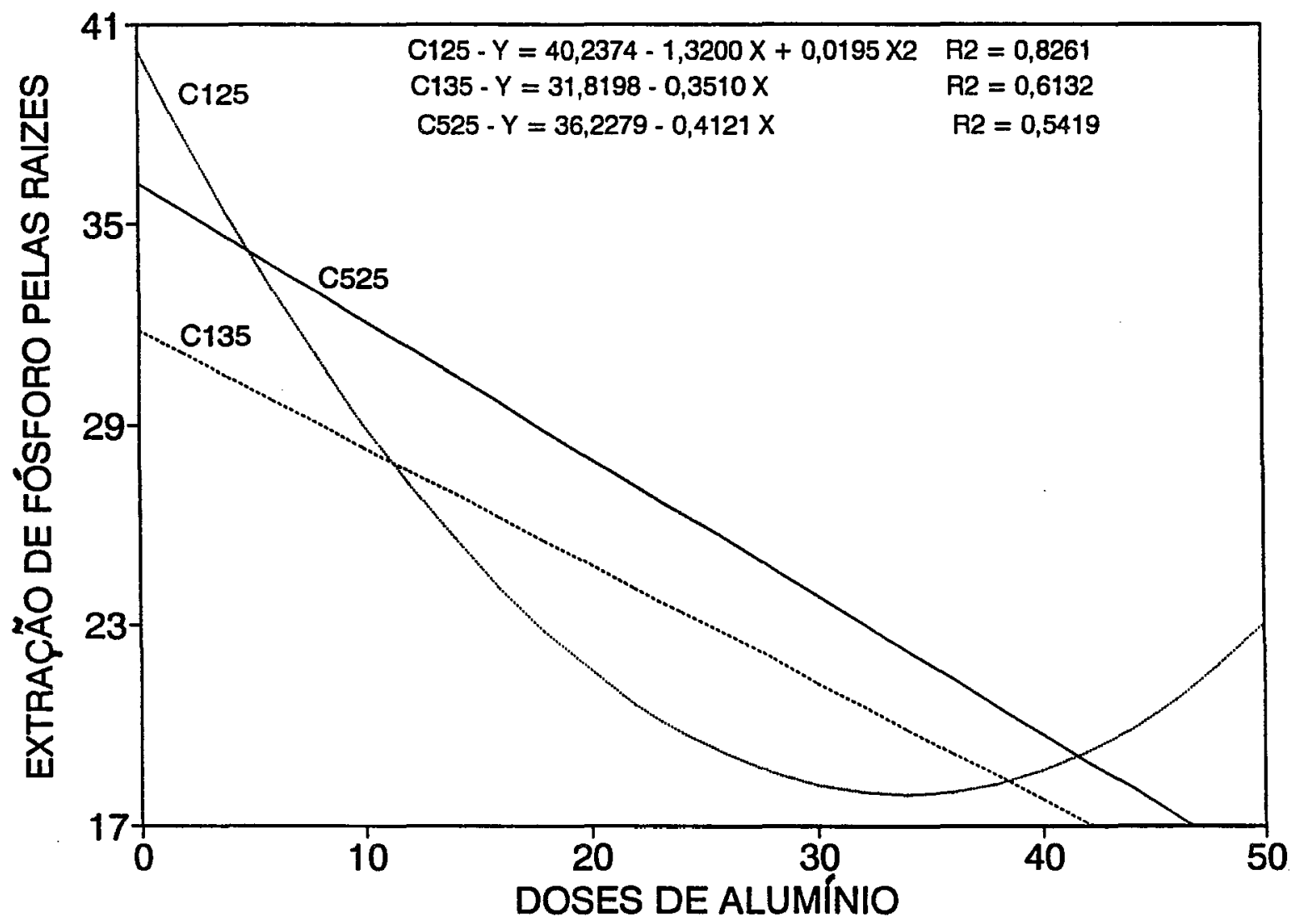

Figura 8. Regressões entre a extração de fósforo pelas raízes (g.planta-1) e os níveis de alumínio (mg.L-1) para três dos seis cultivares estudados. 
Tabela 15. Extração de fósforo pelos colmos (mg.planta $\left.{ }^{-1}\right)$ em função dos níveis de alumínio estudados (mg. $\left.\mathrm{L}^{-1}\right)$, dentro de cada cultivar (médias de quatro repetições).

\begin{tabular}{|c|c|c|c|c|c|c|c|}
\hline \multirow[t]{2}{*}{ Cultivares } & \multicolumn{6}{|c|}{ Alumínio (mg. $\mathrm{L}^{-1}$ ) } & \multirow[t]{2}{*}{ Médias } \\
\hline & 0 & 10 & 20 & 30 & 40 & 50 & \\
\hline 525 & $38,60 \mathrm{Aa}$ & $37,33 \mathrm{Aa}$ & $16,25 \mathrm{ABb}$ & $12,83 \mathrm{Ab}$ & $6,21 \mathrm{Ab}$ & 7,57 Ab & $19,80 \mathrm{~A}$ \\
\hline 135 & $45,31 \mathrm{Aa}$ & $24,47 \mathrm{ABb}$ & $26,27 \mathrm{ABb}$ & $9,22 \mathrm{ABC}$ & $5,01 \mathrm{Ac}$ & $4,36 \mathrm{Ac}$ & $19,11 \mathrm{~A}$ \\
\hline 125 & $32,76 \mathrm{Aa}$ & $22,35 \mathrm{Bab}$ & $25,01 \mathrm{Aab}$ & $12,31 \mathrm{ABbc}$ & $6,01 \mathrm{Ac}$ & $8,62 \mathrm{Ac}$ & $17,84 \mathrm{~A}$ \\
\hline 805 & $10,02 \mathrm{Ba}$ & $6,69 \mathrm{Ca}$ & $6,48 \mathrm{Ba}$ & $4,99 \mathrm{ABa}$ & $5,77 \mathrm{Aa}$ & $5,15 \mathrm{Aa}$ & $6,51 \mathrm{~B}$ \\
\hline 701 & $8,76 \mathrm{Ba}$ & $3,89 \mathrm{Ca}$ & $2,41 \mathrm{Ca}$ & $3,12 \mathrm{Ba}$ & 1,43 Aa & $2,24 \mathrm{Aa}$ & $3,64 \mathrm{~B}$ \\
\hline 425 & $8,99 \mathrm{Ba}$ & $3,43 \mathrm{Ca}$ & $2,96 \mathrm{Ba}$ & $3,20 \mathrm{Ba}$ & $4,76 \mathrm{Aa}$ & 3,39 Aa & $4,45 \mathrm{~B}$ \\
\hline Médias & $24,07 \mathrm{a}$ & $16,36 \mathrm{~b}$ & $13,23 \mathrm{~b}$ & $7,61 \mathrm{c}$ & $4,86 \mathrm{c}$ & $5,22 \mathrm{c}$ & 11,89 \\
\hline
\end{tabular}

- Médias seguidas por letras iguais, maiúsculas na vertical ou minúsculas na horizontal, não diferem entre si pelo teste de Tukey ao nível de $5 \%$ de probabilidade. 
em relação aos níveis de alumínio. Assim, o cultivar C125 praticamente não apresentou redução significativa na extração pelos colmos com até $20 \mathrm{mg} . \mathrm{L}^{-1} \mathrm{de}$ alumínio na solução; o cultivar C525 não apresentou redução na extração de fósforo pelos colmos até $10 \mathrm{mg} . \mathrm{L}^{-1}$; enquanto o cultivar C135 apresentou queda significativa desde o primeiro nível.

O comportamento da extração de fósforo pelos colmos em cada cultivar, em função dos níveis de alumínio aplicados, é apresentado na Figura 9, onde são representadas as equações de regressão entre a extração de fósforo pelos colmos (mg.planta $\left.{ }^{-1}\right)$ e os níveis de alumínio (mg.L-1), para três dos seis cultivares estudados, uma vez que os cultivares C805, C701 e C425 não apresentaram variação significativa na extração pelos colmos, em função dos níveis de alumínio. Assim, todas as regressões representam a redução da extração de fósforo pelos colmos em função dos níveis de alumínio, porém o cultivar C125 apresentou redução representada por equação linear, enquanto os cultivares C525 e C135 apresentaram reduções representadas por equações quadráticas, com mínimos em 53,3 e 54,2 mg.L-1 de alumínio para C525 e C135 respectivamente.

Na Tabela 15 observa-se que, na ausência de alumínio, os cultivares C525, C135 e C125 apresentaram extrações de fósforo pelos colmos significativamente maiores que os demais. Com o aumento do nível de alumínio na solução, os cultivares apresentaram comportamentos variados, sendo o nível 20 mg.L $\mathbf{L}^{-1}$ de alumínio o que melhor separou os cultivares quanto à extração de fósforo pelos colmos.

A Tabela 16 apresenta a extração de fósforo (mg.planta-1) das partes amostradas dentro de cada cultivar, para os níveis 0 e $10 \mathrm{mg} . \mathrm{L}^{-1}$ de alumínio na solução. Observa-se que na ausência de alumínio, os cultivares já apresentavam comportamentos diferentes em relação à extração de fósforo pelas três partes amostradas. Assim, os cultivares C525, C805, C701 e C425 apresentavam extrações de fósforo estatisticamente semelhantes para as três partes amostradas, enquanto o cultivar C135 apresentava extração pelas folhas superior às das raízes e dos colmos e o cultivar C125 apresentava a extração pelas folhas significativamente maior que a dos colmos. Ainda na ausência de alumínio, quanto à extração de fósforo pelas folhas, o cultivar C135 apresentou valores significativamente maiores que os demais cultivares, dos quais as dos cultivares C805, C701 e C425 foram menores que os demais cultivares; quanto à extração 


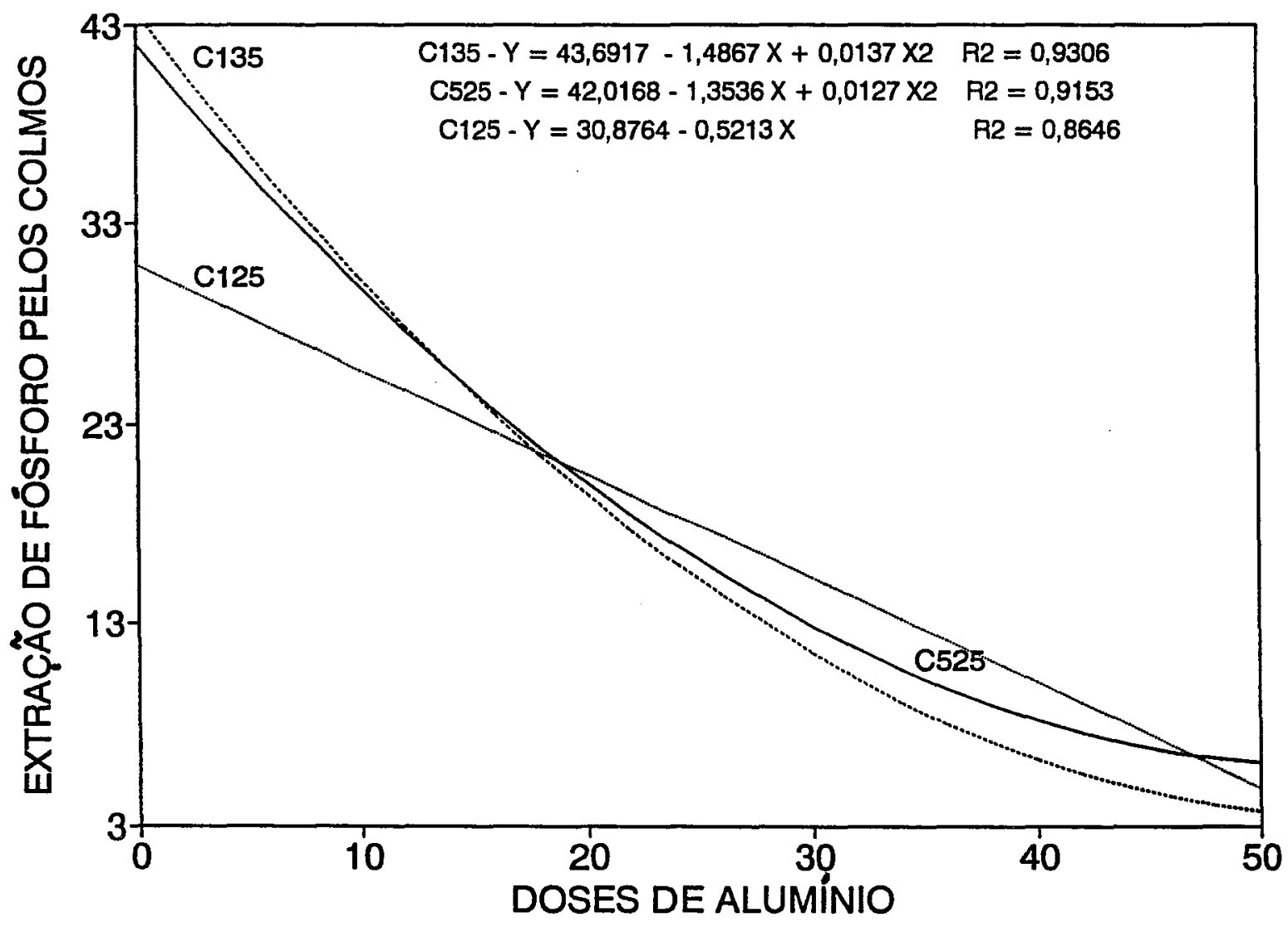

Figura 9. Regressões entre a extração de fósforo pelos colmos (g.planta-1) e os níveis de alumínio (mg. $\mathrm{L}^{\mathbf{- 1}}$ ) para três dos seis cultivares estudados. 
Tabela 16: Extração de fósforo (mg.planta ${ }^{-1}$ ) em função das partes amostradas, dentro de cada cultivar, para os níveis 0 e $10 \mathrm{mg} \cdot \mathrm{L}^{-1}$ de alumínio (médias de quatro repetições).

\begin{tabular}{||c|c|c|c|c||}
\hline \multirow{2}{*}{ Cultivares } & \multicolumn{5}{|c|}{ Nivel 0 de Alumínio } \\
\cline { 2 - 5 } & Folhas & Raízes & Colmos & Médias \\
\hline 525 & $51,70 \mathrm{Ba}$ & $45,62 \mathrm{Aa}$ & $38,90 \mathrm{Aa}$ & $45,31 \mathrm{~A}$ \\
\hline 135 & $71,74 \mathrm{Aa}$ & $38,10 \mathrm{Ab}$ & $45,31 \mathrm{Ab}$ & $51,71 \mathrm{~A}$ \\
\hline 125 & $53,25 \mathrm{Ba}$ & $42,48 \mathrm{Aab}$ & $32,76 \mathrm{Ab}$ & $42,83 \mathrm{~A}$ \\
\hline 805 & $20,80 \mathrm{Ca}$ & $16,88 \mathrm{Ba}$ & $10,02 \mathrm{Ba}$ & $15,90 \mathrm{~B}$ \\
\hline 701 & $13,34 \mathrm{Ca}$ & $13,34 \mathrm{Ba}$ & $8,76 \mathrm{Ba}$ & $11,83 \mathrm{~B}$ \\
\hline 425 & $14,34 \mathrm{Ca}$ & $13,10 \mathrm{Ba}$ & $8,99 \mathrm{Ba}$ & $12,15 \mathrm{~B}$ \\
\hline Médias & $37,53 \mathrm{a}$ & $28,26 \mathrm{~b}$ & $24,07 \mathrm{~b}$ & 29,95 \\
\hline & & Nivel $10 \mathrm{de} \mathrm{Aluminio}$ & \\
\hline 525 & $54,37 \mathrm{Aa}$ & $21,01 \mathrm{ABc}$ & $37,32 \mathrm{Ab}$ & $37,57 \mathrm{~A}$ \\
\hline 135 & $37,42 \mathrm{Ba}$ & $22,81 \mathrm{ABb}$ & $24,47 \mathrm{ABab}$ & $28,23 \mathrm{~A}$ \\
\hline 125 & $39,38 \mathrm{Ba}$ & $24,45 \mathrm{Ab}$ & $22,35 \mathrm{Bb}$ & $28,73 \mathrm{~A}$ \\
\hline 805 & $8,79 \mathrm{Cb}$ & $23,91 \mathrm{ABa}$ & $6,69 \mathrm{Cb}$ & $13,13 \mathrm{~B}$ \\
\hline 701 & $9,14 \mathrm{Ca}$ & $10,91 \mathrm{ABa}$ & $3,89 \mathrm{Ca}$ & $7,98 \mathrm{~B}$ \\
\hline 425 & $6,77 \mathrm{Ca}$ & $13,53 \mathrm{Ba}$ & $3,43 \mathrm{Ca}$ & $7,91 \mathrm{~B}$ \\
\hline Médias & $25,98 \mathrm{a}$ & $19,44 \mathrm{~b}$ & $16,36 \mathrm{~b}$ & 20,59 \\
\hline \hline
\end{tabular}

- Médias seguidas por letras iguais, maiúsculas na vertical ou minúsculas na horizontal, dentro de cada nível de alumínio, não diferem entre si pelo teste de Tukey ao nível de $5 \%$ de probabilidade 
de fósforo pelas raizes e pelos colmos, os cultivares C525, C135 e C125 diferiram dos demais, que não diferiram entre si.

No nível $10 \mathrm{mg} . \mathrm{L}^{\mathbf{- 1}}$ de alumínio observa-se que os cultivares também apresentavam comportamentos diversos em relação à extração de fósforo pelas três partes amostradas. Assim, os cultivares C701 e C425 apresentaram as três partes com extrações estatisticamente semelhantes, enquanto nos demais cultivares, exceto o cultivar C805 onde a extração foi maior pelas raízes, apresentavam extrações de fósforo pelas folhas superior à das demais partes. Ainda no nível $10 \mathrm{mg} . \mathrm{L}^{\mathbf{- 1}}$ de alumínio, quanto à extração de fósforo pelas folhas, o cultivar C525 apresentou valores significativamente maiores que os demais cultivares; quanto à extração pelas raízes, o cultivar C125 diferiu apenas do cultivar $\mathrm{C} 425$, não diferindo dos demais; quanto à extração de fósforo pelos colmos, o cultivar C525 diferiu dos demais cultivares exceto o cultivar C135.

A Tabela 17 apresenta a extração de fósforo (mg.planta-1) das partes amostradas dentro de cada cultivar, para os níveis 20 e $30 \mathrm{mg} . \mathrm{L}^{-1}$ de alumínio na solução. Observa-se que no nível $20 \mathrm{mg} . \mathrm{L}^{-1}$ de alumínio, os cultivares apresentaram comportamentos diferentes em relação à extração de fósforo pelas três partes amostradas. Assim, os cultivares C525, C135, C701 e C425 apresentaram extrações de fósforo pelas três partes estatisticamente semelhantes, enquanto o cultivar $\mathrm{C} 125$ apresentou extração pelas folhas maior que a das raízes e colmos e o cultivar C805 apresentou a extração pelas raízes significativamente maior que a das duas outras partes. Ainda no nível $20 \mathrm{mg} . \mathrm{L}^{\mathbf{- 1}}$ de alumínio, quanto à extração de fósforo pelas folhas, os cultivares C525, C135 e C125 não diferiram entre si, sendo diferentes dos demais; quanto à extração de fósforo pelas raízes, os cultivares diferiram entre si; quanto à extração de fósforo pelos colmos, os cultivares $\mathrm{C} 135$ e C125 diferiram dos demais cultivares, exceto do cultivar C525.

No nível $30 \mathrm{mg} . \mathrm{L}^{\mathbf{- 1}}$ de alumínio, observa-se que os cultivares também apresentavam comportamentos diversos em relação à extração de fósforo pelas três partes amostradas. Assim, os cultivares C125 e C701 apresentaram as três partes com extrações estatisticamente semelhantes, enquanto os demais cultivares apresentaram extrações de fósforo pelas raízes superiores às dos colmos. Ainda no nível $30 \mathrm{mg} . \mathrm{L}^{\mathbf{- 1}}$ de alumínio, quanto à extração de fósforo pelas folhas, os cultivares $\mathrm{C} 525, \mathrm{C} 135$ e $\mathrm{C} 125$ apresentaram os valores maiores, mas 
Tabela 17: Extração de nitrogênio (mg.planta ${ }^{-1}$ ) em função das partes amostradas, dentro de cada cultivar, para os níveis 20 e $30 \mathrm{mg} . \mathrm{L}^{-1}$ de alumínio (médias de quatro repetições).

\begin{tabular}{||c|c|c|c|c||}
\hline \multirow{2}{*}{ Cultivares } & \multicolumn{5}{|c|}{ Nível 20 de Alumínio } \\
\cline { 2 - 5 } & Folhas & Raízes & Colmos & Médias \\
\hline 525 & $26,95 \mathrm{Aa}$ & $23,78 \mathrm{Aa}$ & $16,25 \mathrm{ABa}$ & $22,33 \mathrm{~A}$ \\
\hline 135 & $27,18 \mathrm{Aa}$ & $18,28 \mathrm{Aa}$ & $26,27 \mathrm{Aa}$ & $23,91 \mathrm{~A}$ \\
\hline 125 & $39,84 \mathrm{Aa}$ & $21,28 \mathrm{Ab}$ & $25,01 \mathrm{Ab}$ & $28,71 \mathrm{~A}$ \\
\hline 805 & $8,22 \mathrm{Bb}$ & $21,66 \mathrm{Aa}$ & $6,48 \mathrm{BCb}$ & $12,12 \mathrm{~B}$ \\
\hline 701 & $4,67 \mathrm{Ba}$ & $11,49 \mathrm{Aa}$ & $2,41 \mathrm{Ca}$ & $6,19 \mathrm{~B}$ \\
\hline 425 & $4,66 \mathrm{Ba}$ & $14,46 \mathrm{Aa}$ & $2,96 \mathrm{Ca}$ & $7,36 \mathrm{~B}$ \\
\hline Médias & $18,59 \mathrm{a}$ & $18,49 \mathrm{a}$ & $13,23 \mathrm{~b}$ & 16,77 \\
\hline & & Nivel $30 \mathrm{de} \mathrm{Alumínio}$ & \\
\hline 525 & $25,16 \mathrm{Aab}$ & $28,50 \mathrm{Aa}$ & $12,83 \mathrm{Ab}$ & $22,16 \mathrm{~A}$ \\
\hline 135 & $15,04 \mathrm{ABab}$ & $24,69 \mathrm{Aa}$ & $9,22 \mathrm{Ab}$ & $16,32 \mathrm{AB}$ \\
\hline 125 & $16,82 \mathrm{ABa}$ & $24,04 \mathrm{Aa}$ & $12,31 \mathrm{Aa}$ & $17,72 \mathrm{AB}$ \\
\hline 805 & $10,27 \mathrm{Bab}$ & $21,39 \mathrm{Aa}$ & $4,99 \mathrm{Ab}$ & $12,21 \mathrm{BC}$ \\
\hline 701 & $4,98 \mathrm{Ba}$ & $9,33 \mathrm{Ba}$ & $3,12 \mathrm{Aa}$ & $5,81 \mathrm{D}$ \\
\hline 425 & $6,15 \mathrm{Bab}$ & $17,41 \mathrm{ABa}$ & $3,20 \mathrm{Ab}$ & $8,92 \mathrm{CD}$ \\
\hline Médias & $13,07 \mathrm{~b}$ & $20,89 \mathrm{a}$ & $7,61 \mathrm{c}$ & 13,86 \\
\hline \hline
\end{tabular}

- Médias seguidas por letras iguais, maiúsculas na vertical ou minúsculas na horizontal, dentro de cada nível de alumínio, não diferem entre si pelo teste de Tukey ao nível de $5 \%$ de probabilidade 
somente o primeiro diferiu significativamente dos demais; quanto à extração de fósforo pelas raízes, somente o cultivar $\mathrm{C} 701$ apresentou valor significativamente menor que os demais; quanto à extração pelos colmos os cultivares não diferiram entre si.

A Tabela 18 apresenta a extração de fósforo (mg.planta-1) das partes amostradas dentro de cada cultivar, para os níveis 40 e $50 \mathrm{mg} . \mathrm{L}^{-1}$ de alumínio na solução. Observa-se que no nível $40 \mathrm{mg} . \mathrm{L}^{-1}$ de alumínio, os cultivares apresentaram comportamentos diferentes em relação à extração de fósforo pelas três partes amostradas, assim os cultivares C125, C701 e C425 não diferiram entre si quanto às extrações de fósforo pelas três partes amostradas que foram estatisticamente semelhantes, os cultivares C135 e C805 apresentaram extrações pelas raízes significativamente maiores que as outras partes amostradas e o cultivar C525 apresentou extração pelas raizes maior que a dos colmos. Ainda no nível $40 \mathrm{mg} . \mathrm{L}^{-1}$ de alumínio, quanto à extração de fósforo pelas folhas e pelos colmos, os cultivares não diferiram entre si; quanto à extração de fósforo pelas raízes, somente o cultivar $\mathrm{C701}$ foi estatisticamente menor que os demais.

No nível $50 \mathrm{mg} . \mathrm{L}^{\mathbf{- 1}}$ de alumínio, observa-se que somente o cultivar C125 apresentou comportamento diverso em relação à extração de fósforo pelas três partes amostradas, com extração pelas raízes maior que pelas demais partes, pois nos outros cultivares as partes extraíram de forma semelhante o nutriente. Ainda no nível $50 \mathrm{mg} . \mathrm{L}^{\mathbf{- 1}}$ de alumínio, quanto à extração de fósforo pelas folhas e pelos colmos, os cultivares não diferiram significativamente entre si; quanto à extração pelas raizes, o cultivar C125 diferiu do cultivar C701, não diferindo dos demais.

\subsection{Extração de potássio}

A Tabela 19 apresenta a extração de potássio pelas folhas (mg.planta ${ }^{-1}$ ) em função dos níveis de alumínio estudados (mg.L-1), dentro de cada cultivar. Observa-se que os cultivares, embora tenham apresentado redução na extração de potássio pelas folhas com o aumento da concentração de alumínio da solução, apresentaram comportamentos diversos em relação aos níveis de alumínio. Assim, os cultivares C135 e C125 não apresentaram estatisticamente, redução na extração de potássio pelas folhas com até $20 \mathrm{mg.L}-1$ de alumínio na 
Tabela 18: Extração de fósforo (mg.planta ${ }^{-1}$ ) em função das partes amostradas, dentro de cada cultivar, para os níveis 40 e $50 \mathrm{mg} . \mathrm{L}^{-1}$ de alumínio (médias de quatro repetições).

\begin{tabular}{|c|c|c|c|c||}
\hline \multirow{2}{*}{ Cultivares } & \multicolumn{5}{|c|}{ Nível 40 de Alumínio } \\
\cline { 2 - 5 } & Folhas & Raízes & Colmos & Médias \\
\hline 525 & $13,46 \mathrm{Aab}$ & $20,56 \mathrm{ABa}$ & $6,21 \mathrm{Ab}$ & $13,41 \mathrm{~A}$ \\
\hline 135 & $6,81 \mathrm{Ab}$ & $21,13 \mathrm{Aa}$ & $5,01 \mathrm{Ab}$ & $10,98 \mathrm{AB}$ \\
\hline 125 & $10,09 \mathrm{Aa}$ & $14,98 \mathrm{ABa}$ & $6,01 \mathrm{Aa}$ & $10,36 \mathrm{AB}$ \\
\hline 805 & $8,74 \mathrm{Ab}$ & $22,38 \mathrm{Aa}$ & $5,77 \mathrm{Ab}$ & $12,30 \mathrm{~A}$ \\
\hline 701 & $3,54 \mathrm{Aa}$ & $7,45 \mathrm{Ba}$ & $1,43 \mathrm{Aa}$ & $4,14 \mathrm{C}$ \\
\hline 425 & $3,42 \mathrm{Aa}$ & $9,34 \mathrm{ABa}$ & $4,76 \mathrm{Aa}$ & $5,84 \mathrm{BC}$ \\
\hline Médias & $7,67 \mathrm{~b}$ & $15,97 \mathrm{a}$ & $4,86 \mathrm{~b}$ & 9,50 \\
\hline & & Nível $50 \mathrm{de} \mathrm{Aluminio}$ & \\
\hline 525 & $7,29 \mathrm{Aa}$ & $16,10 \mathrm{ABa}$ & $7,57 \mathrm{Aa}$ & $10,32 \mathrm{AB}$ \\
\hline 135 & $7,12 \mathrm{Aa}$ & $13,25 \mathrm{ABa}$ & $4,36 \mathrm{Aa}$ & $8,25 \mathrm{BC}$ \\
\hline 125 & $9,56 \mathrm{Ab}$ & $23,52 \mathrm{Aa}$ & $8,61 \mathrm{Ab}$ & $13,90 \mathrm{~A}$ \\
\hline 805 & $8,77 \mathrm{Aa}$ & $16,63 \mathrm{ABa}$ & $5,15 \mathrm{Aa}$ & $10,18 \mathrm{AB}$ \\
\hline 701 & $6,25 \mathrm{Aa}$ & $10,20 \mathrm{Ba}$ & $2,24 \mathrm{Aa}$ & $6,23 \mathrm{C}$ \\
\hline 425 & $6,23 \mathrm{Aa}$ & $15,73 \mathrm{ABa}$ & $3,39 \mathrm{Aa}$ & $8,45 \mathrm{BC}$ \\
\hline Médias & $7,54 \mathrm{~b}$ & $15,91 \mathrm{a}$ & $5,22 \mathrm{~b}$ & 9,55 \\
\hline \hline
\end{tabular}

- Médias seguidas por letras iguais, maiúsculas na vertical ou minúsculas na horizontal, dentro de cada nível de alumínio, não diferem entre si pelo teste de Tukey ao nível de $5 \%$ de probabilidade 
Tabela 19. Extração de potássio pelas folhas (mg.planta $\left.{ }^{-1}\right)$ em função dos níveis de alumínio estudados (mg. $\left.\mathrm{L}^{-1}\right)$, dentro de cada cultivar (médias de quatro repetições).

\begin{tabular}{|c|c|c|c|c|c|c|c|}
\hline \multirow[t]{2}{*}{ Cultivares } & \multicolumn{6}{|c|}{ Alumínio (mg. $\left.\mathrm{L}^{-1}\right)$} & \multirow[t]{2}{*}{ Médias } \\
\hline & 0 & 10 & 20 & 30 & 40 & 50 & \\
\hline 525 & $260,81 \mathrm{Aab}$ & $329,99 \mathrm{Aa}$ & $207,75 \mathrm{ABb}$ & $186,36 \mathrm{Abc}$ & 90,93 Acd & $71,59 \mathrm{Ad}$ & $191,24 \mathrm{~A}$ \\
\hline 135 & $267,50 \mathrm{Aa}$ & $230,36 \mathrm{ABa}$ & $227,42 \mathrm{Aa}$ & $93,40 \mathrm{Ab}$ & $52,74 \mathrm{Ab}$ & $71,66 \mathrm{Ab}$ & $157,16 \mathrm{AB}$ \\
\hline 125 & $265,22 \mathrm{Aa}$ & $214,92 \mathrm{ABab}$ & $219,72 \mathrm{Aab}$ & $153,28 \mathrm{Abc}$ & $107,13 \mathrm{Ac}$ & $108,34 \mathrm{Ac}$ & $178,10 \mathrm{~A}$ \\
\hline 805 & $213,69 \mathrm{Aa}$ & $104,62 \mathrm{Cab}$ & $71,80 \mathrm{Cb}$ & $87,70 \mathrm{Ab}$ & $80,47 \mathrm{Ab}$ & $67,73 \mathrm{Ab}$ & $104,33 \mathrm{C}$ \\
\hline 701 & $201,31 \mathrm{Aa}$ & $187,48 \mathrm{BCa}$ & $116,24 \mathrm{BCab}$ & 104,44 Aab & $67,15 \mathrm{Ab}$ & $97,61 \mathrm{Aab}$ & $129,04 \mathrm{BC}$ \\
\hline 425 & $170,21 \mathrm{Aa}$ & $129,96 \mathrm{BCab}$ & $83,90 \mathrm{Cab}$ & $91,79 \mathrm{Aab}$ & $51,70 \mathrm{Ab}$ & 103,05 Aab & $105,10 \mathrm{C}$ \\
\hline Médias & $229,79 \mathrm{a}$ & 199,54 a & $154,47 \mathrm{~b}$ & 119,49 bc & $75,02 d$ & $86,66 \mathrm{~cd}$ & 144,16 \\
\hline
\end{tabular}

- Médias seguidas por letras iguais, maiúsculas na vertical ou minúsculas na horizontal, não diferem entre si pelo teste de Tukey ao nível de $5 \%$ de probabilidade. 
solução, reduzindo sua extração somente a partir de $30 \mathrm{mg} . \mathrm{L}^{\mathbf{- 1}}$, sendo que o segundo apresentou redução significativa nos demais níveis; os cultivares C525 e C805 não apresentaram redução na extração pelas folhas até $10 \mathrm{mg} . \mathrm{L}^{-1} \mathrm{e}$ os cultivares $\mathrm{C} 701$ e C425 apresentaram redução na extração de potássio pelas folhas a partir de $40 \mathrm{mg} . \mathrm{L}^{-1}$ de alumínio, não apresentando redução estatisticamente significativa nos niveis maiores que esse.

O comportamento da extração de potássio pelas folhas em cada cultivar, em função dos níveis de alumínio aplicados, é apresentado na Figura 10, onde são representadas as equações de regressão entre a extração de potássio pelas folhas (mg.planta) e as doses de alumínio (mg.L-1), para os seis cultivares estudados. Assim, todas as regressões representam a redução da extração de potássio pelas folhas em função dos níveis de alumínio, porém os cultivares $\mathrm{C} 125$, C135, C525 e C701 apresentaram reduções representadas por equações lineares, enquanto os cultivares C425 e C805 apresentaram redução representada por equação quadrática, com mínimos em 34,3 e $35,8 \mathrm{mg} . \mathrm{L}^{-1}$ de alumínio para C805 e $\mathrm{C} 425$ respectivamente.

Na Tabela 19 observa-se que, na ausência de alumínio os cultivares não apresentaram diferenças nas extrações de potássio pelas folhas. Com o aumento do nível de alumínio da solução, os cultivares C525, C135 e C125 apresentaram extrações de potássio pelas folhas entre as maiores até $50 \mathrm{mg} . \mathrm{L}^{\mathbf{- 1}}$, embora a partir do nível $30 \mathrm{mg} . \mathrm{L}^{\mathbf{- 1}}$ não diferirem estatisticamente dos demais cultivares estudados.

A Tabela 20 apresenta a extração de potássio pelas raízes (mg.planta) em função dos níveis de alumínio estudados (mg.L ${ }^{\mathbf{- 1}}$ ), dentro de cada cultivar. Observa-se que dos cultivares estudados, somente C525, C135 e C125 apresentaram redução na extração de potássio pelas raizes com o aumento da concentração de alumínio da solução, apresentando entretanto comportamentos diferentes em relação aos níveis de alumínio. Assim, o cultivar C525 não apresentou redução significativa na extração de potássio pelas raízes com até 30 mg.L $\mathbf{~}^{-1}$ de alumínio na solução; o cultivar C135 não apresentou redução na extração de potássio pelas raízes até $20 \mathrm{mg} . \mathrm{L}^{\mathbf{- 1}}$; o cultivar C125 apresentou redução somente a partir de $10 \mathrm{mg} \cdot \mathrm{L}^{\mathbf{- 1}}$ de alumínio, os três não apresentando queda significativa nos demais níveis. 


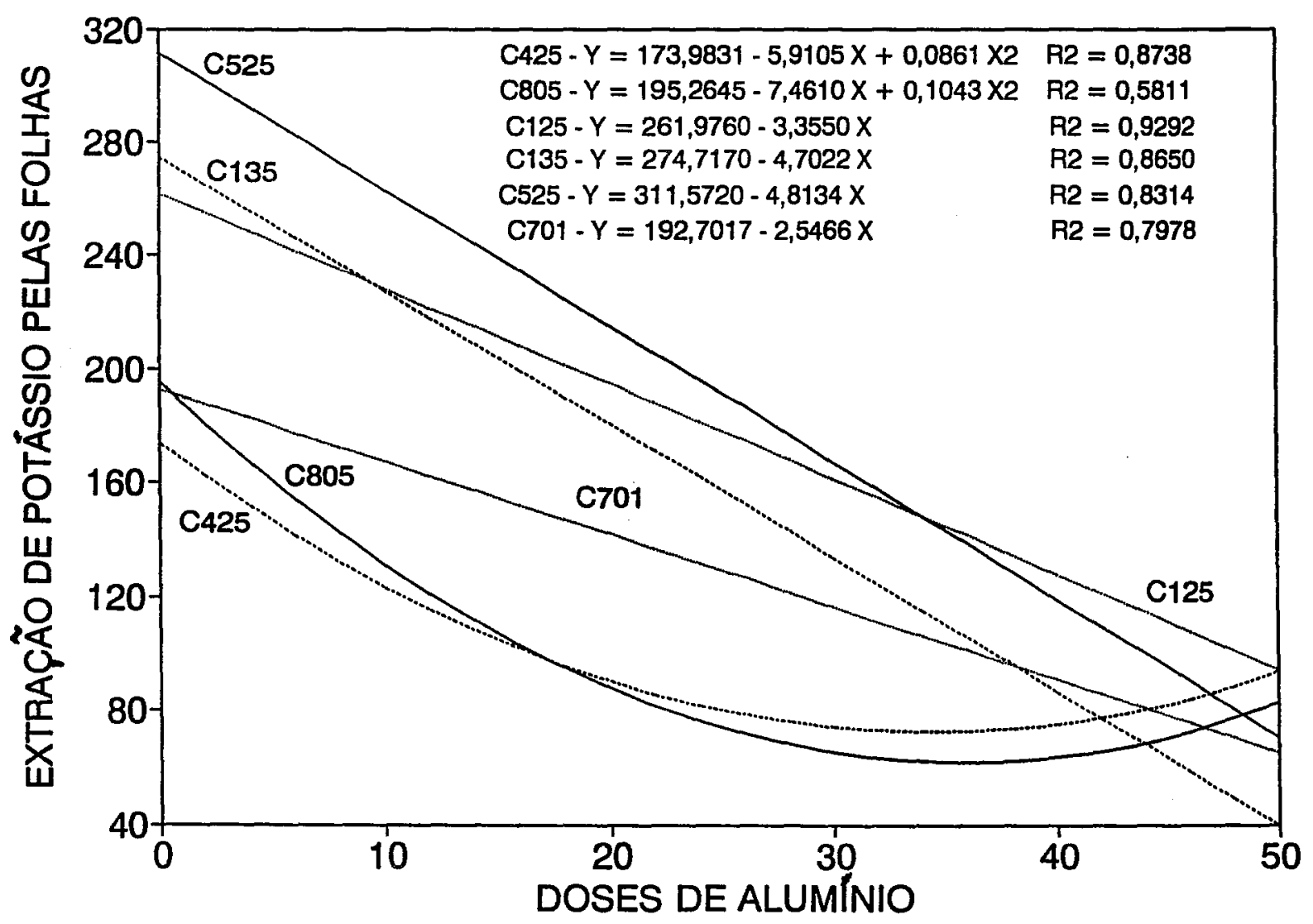

Figura 10. Regressões entre a extração de potássio pelas folhas (g.planta-1) e os níveis de alumínio (mg. $\left.\mathrm{L}^{\mathbf{- 1}}\right)$ para os seis cultivares estudados. 
Tabela 20. Extração de potássio pelas raízes (mg.planta ${ }^{-1}$ ) em função dos níveis de alumínio estudados (mg. $\mathrm{L}^{-1}$ ), dentro de cada cultivar (médias de quatro repetições).

\begin{tabular}{|c|c|c|c|c|c|c|c|}
\hline \multirow{2}{*}{ Cultivares } & \multicolumn{7}{|c|}{ Alumínio (mg. $\mathrm{L}^{-1}$ ) } \\
\cline { 2 - 8 } & 0 & 10 & 20 & 30 & 40 & 50 \\
\hline 525 & $182,62 \mathrm{ABa}$ & $118,47 \mathrm{Aab}$ & $132,78 \mathrm{Aab}$ & $105,10 \mathrm{Aab}$ & $67,76 \mathrm{Ab}$ & $38,79 \mathrm{Ab}$ & $107,59 \mathrm{~A}$ \\
\hline 135 & $207,18 \mathrm{Aa}$ & $114,21 \mathrm{Aab}$ & $115,13 \mathrm{Aab}$ & $104,84 \mathrm{Ab}$ & $45,98 \mathrm{Ab}$ & $44,65 \mathrm{Ab}$ & $103,08 \mathrm{~A}$ \\
\hline 125 & $228,77 \mathrm{Aa}$ & $131,71 \mathrm{Aab}$ & $95,45 \mathrm{Ab}$ & $91,35 \mathrm{Ab}$ & $50,60 \mathrm{Ab}$ & $48,83 \mathrm{Ab}$ & $110,03 \mathrm{~A}$ \\
\hline 805 & $77,34 \mathrm{Ba}$ & $81,67 \mathrm{Aa}$ & $55,65 \mathrm{Aa}$ & $34,88 \mathrm{Aa}$ & $41,37 \mathrm{Aa}$ & $34,13 \mathrm{Aa}$ & $54,17 \mathrm{~A}$ \\
\hline 701 & $88,99 \mathrm{Ba}$ & $74,29 \mathrm{Aa}$ & $48,94 \mathrm{Aa}$ & $37,52 \mathrm{Aa}$ & $24,60 \mathrm{Aa}$ & $33,60 \mathrm{Aa}$ & $51,32 \mathrm{~B}$ \\
\hline 425 & $88,23 \mathrm{Ba}$ & $65,05 \mathrm{Aa}$ & $47,27 \mathrm{Aa}$ & $44,02 \mathrm{Aa}$ & $31,51 \mathrm{Aa}$ & $59,16 \mathrm{Aa}$ & $55,87 \mathrm{~B}$ \\
\hline Médias & $145,52 \mathrm{a}$ & $97,56 \mathrm{~b}$ & $82,53 \mathrm{bc}$ & $69,62 \mathrm{c}$ & $43,64 \mathrm{~d}$ & $43,19 \mathrm{~d}$ & 80,34 \\
\hline
\end{tabular}

- Médias seguidas por letras iguais, maiúsculas na vertical ou minúsculas na horizontal, não diferem entre si pelo teste de Tukey ao nível de $5 \%$ de probabilidade. 
O comportamento da extração de potássio pelas raízes em cada cultivar, em função dos níveis de alumínio aplicados, é apresentado na Figura 11, onde são representadas as equações de regressão entre a extração de potássio pelas raízes (mg.planta-1) e as doses de alumínio (mg.L-1), para os seis cultivares estudados. Assim, todas as regressões representam a redução da extração pelas raízes em função dos níveis de alumínio, porém os cultivares C525, C701 e C805 apresentaram reduções representadas por equações lineares, enquanto os demais cultivares apresentaram reduções representadas por equações quadráticas, com mínimos em 32,$2 ; 47,4$ e 55,5 mg.L $\mathrm{L}^{-1}$ de alumínio para os cultivares $\mathrm{C} 425, \mathrm{C} 125$ e $\mathrm{C} 135$ respectivamente.

$\mathrm{Na}$ Tabela 20 observa-se que, exceto na ausência de alumínio, todos os cultivares estudados apresentaram semelhantes extrações de potássio pelas raízes, não diferindo estatisticamente entre si. $\mathrm{O}$ nível $20 \mathrm{mg} . \mathrm{L}^{-1}$ foi o que melhor diferenciou os cultivares, quanto ao seu comportamento em relação ao alumínio. Assim, nesse nivel, os cultivares C135 e C125 apresentaram as maiores extração de potássio pelas raízes, diferindo significativamente dos cultivares C805, C701 e C425.

A Tabela 21 apresenta a extração de potássio pelos colmos (mg.planta-1) em função dos níveis de alumínio estudados (mg.L $\left.{ }^{-1}\right)$, dentro de cada cultivar. Observa-se que dos cultivares estudados, somente C525, C135, C125 e C701 apresentaram redução na extração de potássio pelos colmos, com o aumento da concentração de alumínio da solução, apresentando comportamentos diversos em relação aos níveis de alumínio. Assim, o cultivar C125 praticamente não apresentou redução significativa na extração pelos colmos com até $30 \mathrm{mg} . \mathrm{L}^{-1}$ de alumínio na solução; os cultivares C525 e C701 não apresentaram redução na extração de potássio pelos colmos até $10 \mathrm{mg} . \mathrm{L}^{\mathbf{- 1}}$, sendo que enquanto o primeiro não apresentava uma queda significativa nos demais níveis, o segundo não apresentou redução significativa da extração nas mesmas condições. $O$ cultivar C135 apresentou redução significativa a partir de $10 \mathrm{mg} . \mathrm{L}^{-1}$ de alumínio.

O comportamento da extração de potássio pelos colmos em cada cultivar, em função dos níveis de alumínio aplicados, é apresentado na Figura 12, onde são representadas as equações de regressão entre a extração de potássio pelos colmos (mg.planta-1) e os níveis de alumínio (mg.L-1), para quatro dos seis cultivares estudados, uma vez que os cultivares C805 e C425 não apresentaram 


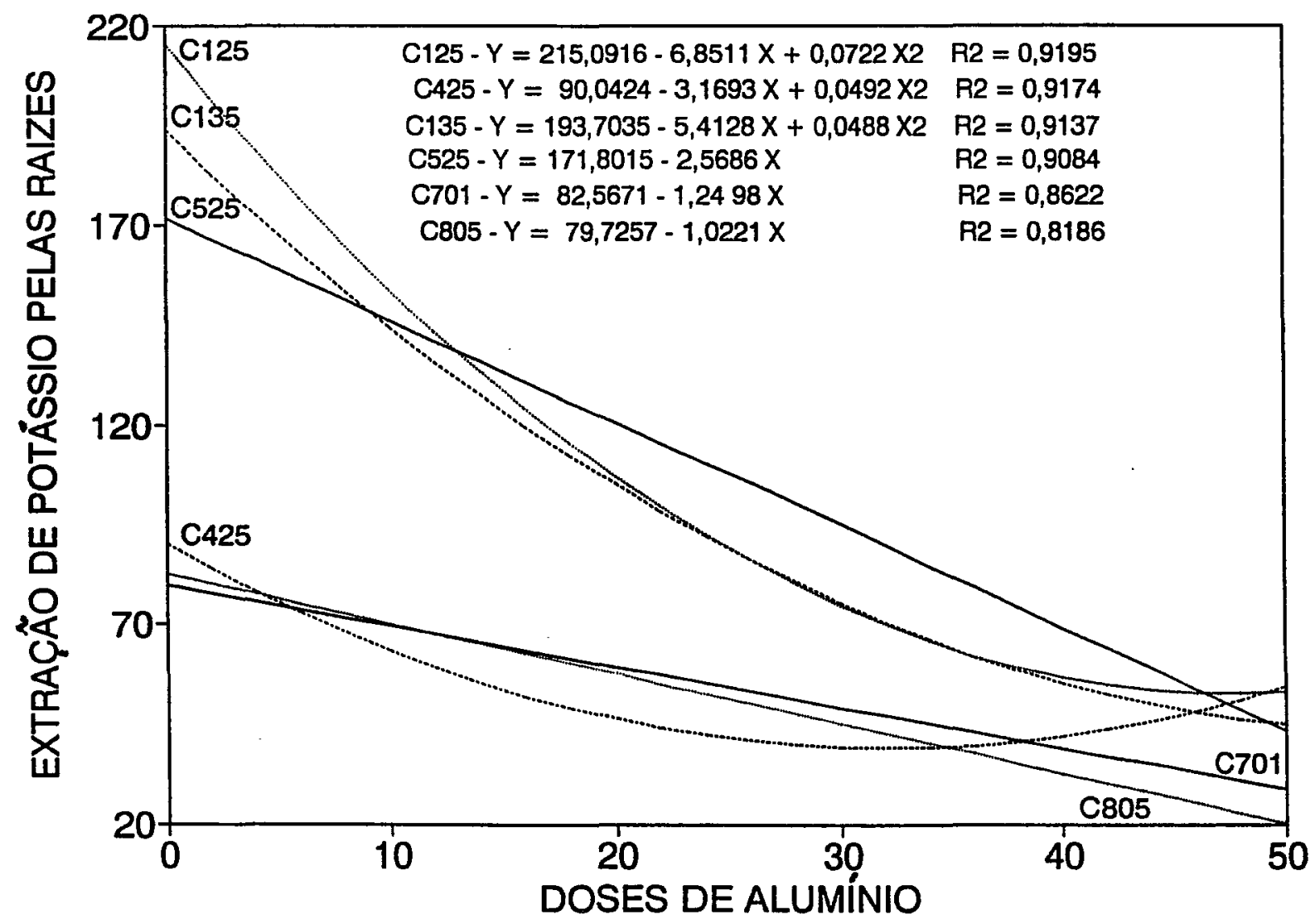

Figura 11. Regressões entre a extração de potássio pelas raízes (g.planta-1) e os níveis de alumínio (mg.L ${ }^{-1}$ ) para os seis cultivares estudados. 
Tabela 21. Extração de potássio pelos colmos (mg.planta ${ }^{-1}$ ) em função dos níveis de alumínio estudados (mg. $\mathrm{L}^{-1}$ ), dentro de cada cultivar (médias de quatro repetições).

\begin{tabular}{|c|c|c|c|c|c|c|c|}
\hline \multirow[t]{2}{*}{ Cultivares } & \multicolumn{6}{|c|}{ Alumínio (mg. $\mathrm{L}^{-1}$ ) } & \multirow[t]{2}{*}{ Médias } \\
\hline & 0 & 10 & 20 & 30 & 40 & 50 & \\
\hline 525 & $417,35 \mathrm{Aa}$ & $420,20 \mathrm{Aa}$ & $232,64 \mathrm{Ab}$ & $177,90 \mathrm{ABbc}$ & 73,70 Ac & $81,39 \mathrm{ABC}$ & $233,86 \mathrm{~A}$ \\
\hline 135 & $452,14 \mathrm{Aa}$ & $236,23 \mathrm{Bb}$ & $224,08 \mathrm{Ab}$ & $142,67 \mathrm{ABCbc}$ & $69,48 \mathrm{Ac}$ & $73,18 \mathrm{ABc}$ & $199,63 \mathrm{~A}$ \\
\hline 125 & $254,14 \mathrm{Bab}$ & $274,47 \mathrm{Ba}$ & 195,38 Aabc & 190,89 Aabc & $119,94 \mathrm{Ac}$ & $158,76 \mathrm{Abc}$ & $198,93 \mathrm{~A}$ \\
\hline 805 & $104,93 \mathrm{Ca}$ & $52,46 \mathrm{Ca}$ & $55,58 \mathrm{Ba}$ & $50,19 \mathrm{Ca}$ & $63,10 \mathrm{Aa}$ & $45,76 \mathrm{Ba}$ & $62,00 \mathrm{~B}$ \\
\hline 701 & $148,51 \mathrm{BCa}$ & $78,16 \mathrm{Cab}$ & $37,53 \mathrm{Bb}$ & $56,67 \mathrm{Cab}$ & $25,41 \mathrm{Ab}$ & $34,16 \mathrm{Bb}$ & $63,41 \mathrm{~B}$ \\
\hline 425 & $102,29 \mathrm{Ca}$ & $62,23 \mathrm{Ca}$ & $53,81 \mathrm{Ba}$ & $82,12 \mathrm{BCa}$ & $75,37 \mathrm{Aa}$ & $70,91 \mathrm{ABa}$ & $74,46 \mathrm{~B}$ \\
\hline Médias & $246,56 \mathrm{a}$ & $187,29 \mathrm{ab}$ & $133,17 b c$ & $116,74 \mathrm{~cd}$ & $71,17 \mathrm{~d}$ & $77,36 \mathrm{~cd}$ & 138,71 \\
\hline
\end{tabular}

- Médias seguidas por letras iguais, maiúsculas na vertical ou minúsculas na horizontal, não diferem entre si pelo teste de Tukey ao nível de $5 \%$ de probabilidade. 


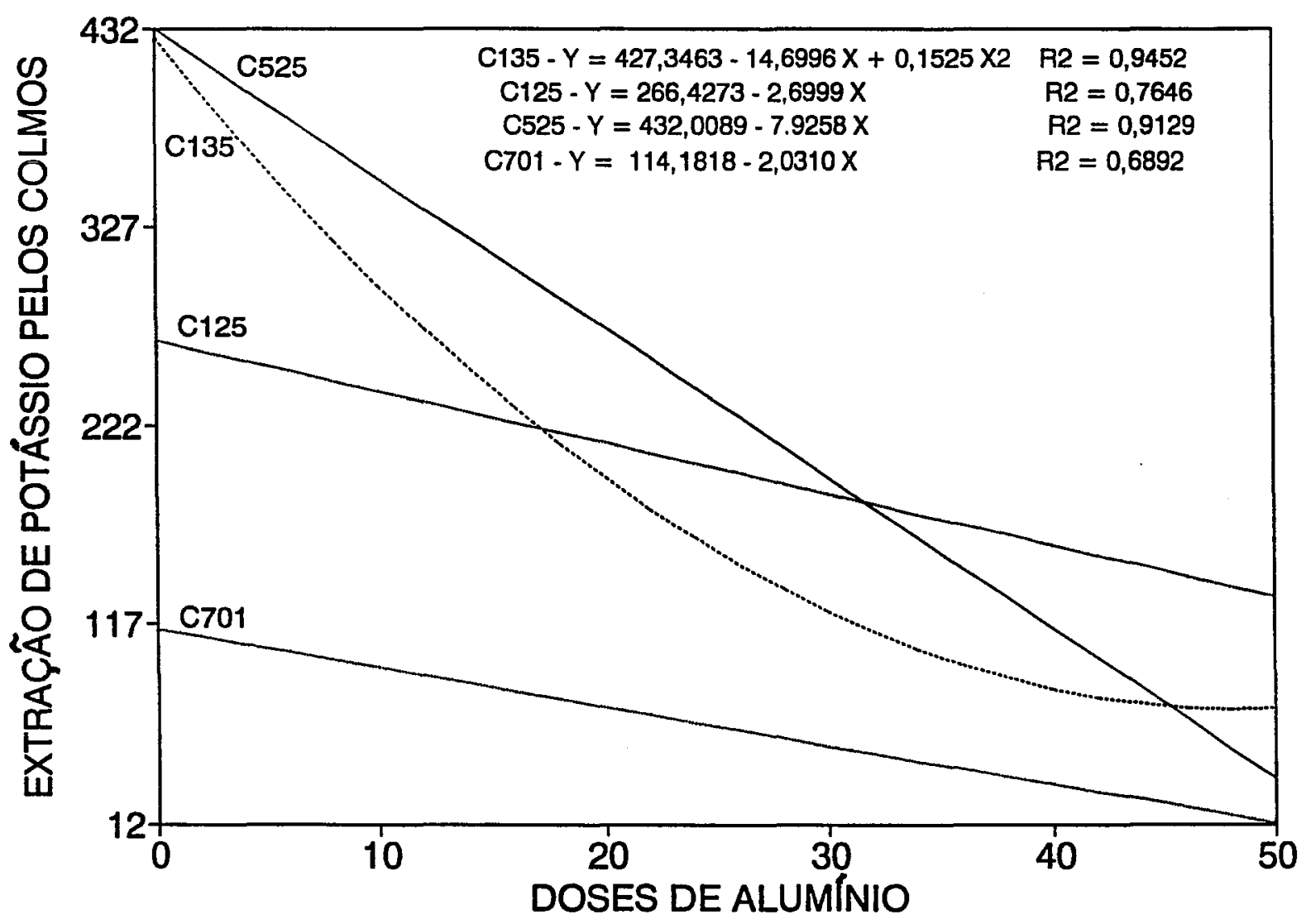

Figura 12. Regressões entre a extração de potássio pelos colmos (g.planta-1) e os níveis de alumínio (mg.L-1) para quatro dos seis cultivares estudados. 
redução na extração pelos colmos em função dos níveis de alumínio. Assim, todas as regressões representam a redução da extração de potássio pelos colmos em função dos níveis de alumínio, porém os cultivares C125, C525 e C701 apresentaram reduções representadas por equações lineares, enquanto o cultivar C135 apresentou redução representada por uma equação quadrática, com mínimo em 48,2 mg.L $\mathrm{L}^{-1}$ de alumínio.

Na Tabela 21 observa-se que, na ausência de alumínio, os cultivares C525 e C135 apresentaram extrações de potássio pelos colmos significativamente maiores que os demais. Com o aumento do nível de alumínio da solução, o cultivar C525 apresentou os maiores extrações de potássio pelos colmos até 30 mg. $L^{-1}$, quando então não diferiu dos demais, tornando-se semelhante às extrações de outros cultivares nos níveis maiores.

A Tabela 22 apresenta a extração de potássio (mg.planta-1) das partes amostradas dentro de cada cultivar, para os níveis 0 e $10 \mathrm{mg} . \mathrm{L}^{-1}$ de alumínio na solução. Observa-se que na ausência de alumínio, os cultivares já apresentavam comportamentos diferentes em relação à extração de potássio pelas três partes amostradas. Assim, os cultivares $\mathrm{C} 125$ e C425 apresentavam extrações de potássio pelas três partes amostradas estatisticamente semelhantes, enquanto os cultivares C525 e C135 apresentavam extrações pelos colmos superiores às das demais partes amostradas, o cultivar C805 apresentava a extração pelas folhas significativamente maior que a das raízes e dos colmos e o cultivar C701 onde a extração pelas folhas foi somente superior à das raizes. Ainda na ausência de alumínio, quanto à extração de potássio pelas folhas, os cultivares não apresentaram valores significativamente diferentes; quanto à extração de potássio pelas raízes, os cultivares $\mathrm{C} 135$ e $\mathrm{C} 125$ diferiram dos demais, exceto do cultivar C525, quanto à extração de potássio pelos colmos, os cultivares C525 e C135 diferiram dos demais cultivares.

No nível $10 \mathrm{mg} . \mathrm{L}^{\mathbf{- 1}}$ de alumínio, observa-se que os cultivares também apresentavam comportamentos diversos em relação à extração de potássio pelas três partes amostradas. Assim, os cultivares C805 e C425 apresentaram as três partes com extrações estatisticamente semelhantes, enquanto os cultivares C525 e C135 apresentavam extrações de potássio pelas folhas e colmos, superiores à das raízes; para o cultivar C701 a extração de potássio pelas folhas foi maior que a das duas outras partes amostradas e para o cultivar C125 a 
Tabela 22: Extração de potássio (mg.planta ${ }^{-1}$ ) em função das partes amostradas, dentro de cada cultivar, para os níveis 0 e $10 \mathrm{mg} \cdot \mathrm{L}^{-1}$ de alumínio (médias de quatro repetições).

\begin{tabular}{||c|c|c|c|c||}
\hline \multirow{2}{*}{ Cultivares } & \multicolumn{5}{|c|}{ Nível 0 de Alumínio } \\
\cline { 2 - 5 } & Folhas & Raízes & Colmos & Médias \\
\hline 525 & $260,81 \mathrm{Ab}$ & $182,63 \mathrm{ABb}$ & $417,35 \mathrm{Aa}$ & $286,93 \mathrm{~A}$ \\
\hline 135 & $267,50 \mathrm{Ab}$ & $207,18 \mathrm{Ab}$ & $452,14 \mathrm{Aa}$ & $308,94 \mathrm{~A}$ \\
\hline 125 & $265,23 \mathrm{Aa}$ & $228,77 \mathrm{Aa}$ & $254,14 \mathrm{Ba}$ & $249,38 \mathrm{~A}$ \\
\hline 805 & $213,69 \mathrm{Aa}$ & $77,34 \mathrm{Bb}$ & $104,93 \mathrm{Cb}$ & $131,99 \mathrm{~B}$ \\
\hline 701 & $201,31 \mathrm{Aa}$ & $88,99 \mathrm{Bb}$ & $148,51 \mathrm{BCab}$ & $146,27 \mathrm{~B}$ \\
\hline 425 & $170,22 \mathrm{Aa}$ & $88,23 \mathrm{Ba}$ & $102,29 \mathrm{Ca}$ & $120,24 \mathrm{~B}$ \\
\hline Médias & $229,79 \mathrm{a}$ & $145,52 \mathrm{~b}$ & $246,56 \mathrm{a}$ & 207,29 \\
\hline & & Nível $10 \mathrm{de} \mathrm{Alumínio}$ & \\
\hline 525 & $330,00 \mathrm{Aa}$ & $118,47 \mathrm{Ab}$ & $420,19 \mathrm{Aa}$ & $289,55 \mathrm{~A}$ \\
\hline 135 & $230,26 \mathrm{ABa}$ & $114,21 \mathrm{Ab}$ & $236,23 \mathrm{Ba}$ & $193,57 \mathrm{~B}$ \\
\hline 125 & $214,91 \mathrm{ABab}$ & $131,71 \mathrm{Ab}$ & $274,46 \mathrm{Ba}$ & $207,03 \mathrm{~B}$ \\
\hline 805 & $104,62 \mathrm{Ca}$ & $81,67 \mathrm{Aa}$ & $52,46 \mathrm{Ca}$ & $79,59 \mathrm{C}$ \\
\hline 701 & $187,48 \mathrm{BCa}$ & $74,29 \mathrm{Ab}$ & $78,16 \mathrm{Cb}$ & $113,31 \mathrm{C}$ \\
\hline 425 & $129,96 \mathrm{BCa}$ & $65,01 \mathrm{Aa}$ & $62,23 \mathrm{Ca}$ & $85,74 \mathrm{C}$ \\
\hline Médias & $199,54 \mathrm{a}$ & $97,56 \mathrm{a}$ & $187,29 \mathrm{a}$ & 161,46 \\
\hline \hline
\end{tabular}

- Médias seguidas por letras iguais, maiúsculas na vertical ou minúsculas na horizontal, dentro de cada nível de alumínio, não diferem entre si pelo teste de Tukey ao nível de $5 \%$ de probabilidade 
extração pelas raizes diferiu da dos colmos. Ainda no nível $10 \mathrm{mg} . \mathrm{L}^{\mathbf{- 1}}$ de alumínio, quanto à extração de potássio pelas folhas, o cultivar C525 apresentou valores significativamente maiores que os demais cultivares; quanto à extração pelas raízes, o cultivar C525 diferiu apenas do cultivar C425, não diferindo dos demais; quanto à extração de potássio pelos colmos, o cultivar C525 diferiu dos demais cultivares.

A Tabela 23 apresenta a extração de potássio (mg.planta ${ }^{-1}$ ) das partes amostradas dentro de cada cultivar, para os níveis 20 e $30 \mathrm{mg} . \mathrm{L}^{-1}$ de alumínio na solução. Observa-se que no nível $20 \mathrm{mg} . \mathrm{L}^{-1}$ de alumínio, os cultivares apresentaram comportamentos diferentes em relação à extração de potássio pelas três partes amostradas. Assim, os cultivares C525, C805, C701 e C425 apresentaram as extrações de potássio pelas três partes estatisticamente semelhantes, enquanto o cultivar C135 apresentou extração pelas folhas e pelos colmos maior que a das raízes e o cultivar $\mathrm{C} 125$ que apresentava a extração pelas folhas significativamente maior que a das raízes. Ainda no nível $20 \mathrm{mg} . \mathrm{L}^{-1}$ de alumínio, quanto à extração de potássio pelas folhas, os cultivares C525, C135 e C125 diferiram dos demais, exceto o cultivar C701 que apresentou extração semelhante a deles; quanto à extração de potássio pelas raizes, os cultivares não apresentaram diferenças estatísticas; quanto à extração de potássio pelos colmos, os cultivares $\mathrm{C} 525, \mathrm{C} 135$ e $\mathrm{C} 125$ diferiram dos demais cultivares.

No nível $30 \mathrm{mg} . \mathrm{L}^{-1}$ de alumínio, observa-se que os cultivares não apresentaram comportamentos diversos em relação à extração de potássio pelas três partes amostradas, a extração de potássio pelas folhas e pelas raízes não diferiram entre si, enquanto para os colmos, o cultivar C125 diferiu dos demais

A Tabela 24 apresenta a extração de potássio (mg.planta-1) das partes amostradas dentro de cada cultivar, para os níveis 40 e $50 \mathrm{mg} . \mathrm{L}^{-1}$ de alumínio na solução. Observa-se que no nível $40 \mathrm{mg} \cdot \mathrm{L}^{-1}$ de alumínio, os cultivares não apresentaram comportamentos diferentes em relação à extração de potássio pelas três partes amostradas, pois os cultivares não diferiram entre si quanto às extrações de potássio pelas três partes amostradas que foram estatisticamente semelhantes. Ainda no nível $40 \mathrm{mg} \cdot \mathrm{L}^{-1}$ de alumínio, quanto à extração de potásșio pelas folhas, pelas raízes e pelos colmos, os cultivares não diferiram entre si. 
Tabela 23: Extração de potássio (mg.planta ${ }^{-1}$ em função das partes amostradas, dentro de cada cultivar, para os níveis 20 e $30 \mathrm{mg} . \mathrm{L}^{-1}$ de alumínio (médias de quatro repetições).

\begin{tabular}{||c|c|c|c|c||}
\hline \multirow{2}{*}{ Cultivares } & \multicolumn{5}{|c|}{ Pível 20 de Alumínio } \\
\cline { 2 - 5 } & Folhas & Raízes & Colmos & Médias \\
\hline 525 & $207,75 \mathrm{Aa}$ & $132,78 \mathrm{Aa}$ & $232,64 \mathrm{Aa}$ & $191,07 \mathrm{~A}$ \\
\hline 135 & $227,41 \mathrm{Aa}$ & $115,13 \mathrm{Ab}$ & $224,08 \mathrm{Aa}$ & $188,87 \mathrm{~A}$ \\
\hline 125 & $219,72 \mathrm{Aa}$ & $95,45 \mathrm{Ab}$ & $195,38 \mathrm{Aab}$ & $170,18 \mathrm{~A}$ \\
\hline 805 & $71,80 \mathrm{Ba}$ & $55,65 \mathrm{Aa}$ & $55,58 \mathrm{Ba}$ & $61,01 \mathrm{~B}$ \\
\hline 701 & $116,24 \mathrm{ABa}$ & $48,94 \mathrm{Aa}$ & $37,53 \mathrm{Ba}$ & $67,57 \mathrm{~B}$ \\
\hline 425 & $83,90 \mathrm{Ba}$ & $47,27 \mathrm{Aa}$ & $53,81 \mathrm{Ba}$ & $61,66 \mathrm{~B}$ \\
\hline Médias & $154,47 \mathrm{a}$ & $82,53 \mathrm{~b}$ & $133,17 \mathrm{a}$ & 123,39 \\
\hline & & Nível $30 \mathrm{de} \mathrm{Alumíni}$ & & $156,45 \mathrm{~A}$ \\
\hline 525 & $186,35 \mathrm{Aa}$ & $105,10 \mathrm{Aa}$ & $177,90 \mathrm{ABa}$ & $109,14 \mathrm{~B}$ \\
\hline 135 & $93,39 \mathrm{Aa}$ & $91,35 \mathrm{Aa}$ & $142,67 \mathrm{ABCa}$ & $1090 \mathrm{Aanta}$ \\
\hline 125 & $153,28 \mathrm{Aa}$ & $104,84 \mathrm{Aa}$ & $190,89 \mathrm{Aa}$ & $149,67 \mathrm{~A}$ \\
\hline 805 & $87,70 \mathrm{Aa}$ & $34,87 \mathrm{Aa}$ & $50,19 \mathrm{Ca}$ & $57,59 \mathrm{C}$ \\
\hline 701 & $104,43 \mathrm{Aa}$ & $37,52 \mathrm{Aa}$ & $56,67 \mathrm{Ca}$ & $66,21 \mathrm{C}$ \\
\hline 425 & $91,80 \mathrm{Aa}$ & $44,02 \mathrm{Aa}$ & $82,12 \mathrm{Ba}$ & $72,65 \mathrm{BC}$ \\
\hline Médias & $119,49 \mathrm{a}$ & $69,62 \mathrm{~b}$ & $116,74 \mathrm{a}$ & 101,95 \\
\hline \hline
\end{tabular}

- Médias seguidas por letras iguais, maiúsculas na vertical ou minúsculas na horizontal, dentro de cada nível de alumínio, não diferem entre si pelo teste de Tukey ao nível de $5 \%$ de probabilidade 
Tabela 24: Extração de potássio (mg.planta ${ }^{-1}$ ) em função das partes amostradas, dentro de cada cultivar, para os níveis 40 e $50 \mathrm{mg} . \mathrm{L}^{-1}$ de alumínio (médias de quatro repetições).

\begin{tabular}{||c|c|c|c|c||}
\hline \multirow{2}{*}{ Cultivares } & \multicolumn{5}{|c|}{ Nível 40 de Alumínio } \\
\cline { 2 - 5 } & Folhas & Raízes & Colmos & Médias \\
\hline 525 & $90,93 \mathrm{Aa}$ & $67,76 \mathrm{Aa}$ & $73,70 \mathrm{Aa}$ & $77,46 \mathrm{~A}$ \\
\hline 135 & $52,74 \mathrm{Aa}$ & $45,98 \mathrm{Aa}$ & $69,48 \mathrm{Aa}$ & $56,07 \mathrm{~A}$ \\
\hline 125 & $107,13 \mathrm{Aa}$ & $50,60 \mathrm{Aa}$ & $119,94 \mathrm{Aa}$ & $92,55 \mathrm{~A}$ \\
\hline 805 & $80,47 \mathrm{Aa}$ & $41,37 \mathrm{Aa}$ & $63,10 \mathrm{Aa}$ & $61,65 \mathrm{~A}$ \\
\hline 701 & $67,15 \mathrm{Aa}$ & $24,60 \mathrm{Aa}$ & $25,42 \mathrm{Aa}$ & $30,56 \mathrm{~A}$ \\
\hline 425 & $51,70 \mathrm{Aa}$ & $31,51 \mathrm{Aa}$ & $75,37 \mathrm{Aa}$ & $52,86 \mathrm{Aa}$ \\
\hline Médias & $75,02 \mathrm{a}$ & $43,64 \mathrm{~b}$ & $71,17 \mathrm{a}$ & 63,27 \\
\hline & & Nível $50 \mathrm{de} \mathrm{Alumínio}$ & \\
\hline 525 & $71,59 \mathrm{Aa}$ & $38,79 \mathrm{Aa}$ & $81,39 \mathrm{ABa}$ & $63,92 \mathrm{BC}$ \\
\hline 135 & $71,66 \mathrm{Aa}$ & $44,65 \mathrm{Aa}$ & $73,18 \mathrm{Ba}$ & $63,16 \mathrm{BC}$ \\
\hline 125 & $108,34 \mathrm{Aa}$ & $48,83 \mathrm{Aa}$ & $158,76 \mathrm{Aa}$ & $105,3 \mathrm{~A}$ \\
\hline 805 & $67,73 \mathrm{Aa}$ & $34,13 \mathrm{Aa}$ & $45,76 \mathrm{Aa}$ & $49,20 \mathrm{C}$ \\
\hline 701 & $97,61 \mathrm{Aa}$ & $33,60 \mathrm{Aa}$ & $34,16 \mathrm{Ba}$ & $55,12 \mathrm{BC}$ \\
\hline 425 & $103,05 \mathrm{Aa}$ & $59,16 \mathrm{Aa}$ & $70,91 \mathrm{ABa}$ & $77,71 \mathrm{~B}$ \\
\hline Médias & $86,66 \mathrm{a}$ & $43,19 \mathrm{~b}$ & $77,36 \mathrm{a}$ & 69,07 \\
\hline
\end{tabular}

- Médias seguidas por letras iguais, maiúsculas na vertical ou minúsculas na horizontal, dentro de cada nível de alumínio, não diferem entre si pelo teste de Tukey ao nível de $5 \%$ de probabilidade 
No nível 50 mg.L $\mathbf{~}^{-1}$ de alumínio, observa-se que os cultivares não apresentaram comportamentos diversos em relação à extração de potássio pelas três partes amostradas. Para a extração de potássio pelas folhas e pelas raizes, os cultivares não diferiram significativamente entre si; quanto à extração pelos colmos, os cultivares C125 e C805 diferiram dos demais cultivares, exceto do cultivar C525, que também não diferiu dos demais.

\subsection{Extração de cálcio}

A Tabela 25 apresenta a extração de cálcio pelas folhas (mg. planta-1) em função dos níveis de alumínio estudados (mg.L-1), dentro de cada cultivar. Observa-se que os cultivares, embora tenham todos apresentado redução na extração de cálcio pelas folhas com o aumento da concentração de alumínio da solução, apresentaram comportamentos diversos em relação aos níveis de alumínio. Assim, os cultivares C125, C805 e C701 não apresentaram estatisticamente redução na extração de cálcio pelas folhas com até $20 \mathrm{mg} . \mathrm{L}^{-1}$ de alumínio na solução, reduzindo sua extração somente em $30 \mathrm{mg} . \mathrm{L}^{-1}$; o cultivar C425 não apresentou redução na extração pelas folhas até $30 \mathrm{mg} . \mathrm{L}^{-1}$, enquanto o cultivar C525 apresentou redução na extração de cálcio pelas folhas a partir de 20 mg. $L^{-1}$ de alumínio e o cultivar C135 iniciou a redução nível $10 \mathrm{mg} . \mathrm{L}^{-1}$ de alumínio.

O comportamento da extração de cálcio pelas folhas em cada cultivar, em função dos níveis de alumínio aplicados, é apresentado na Figura 13, onde são representadas as equações de regressão entre a extração de cálcio pelas folhas (mg.planta-1) e as doses de alumínio (mg.L-1), para os seis cultivares estudados. Assim, todas as regressões representam a redução da extração de cálcio pelas folhas em função dos níveis de alumínio, porém os cultivares $\mathrm{C} 125$, C425, C525, C701 e C805 apresentaram reduções representadas por equações lineares, enquanto o cultivar $\mathrm{C} 135$ apresentou redução representada por equação quadrática, com mínimo em $55,1 \mathrm{mg} . \mathrm{L}^{\mathbf{- 1}}$ de alumínio.Tabela 25 observa-se que, na ausência de alumínio o cultivar C135 apresentou extração de cálcio pelas folhas significativamente maior que os demais, exceto os cultivares C525 e C125. Com o aumento do nível de alumínio da solução, os cultivares C525 e C125 apresentaram extrações de cálcio pelas folhas maiores que os demais cultivares. 
Tabela 25. Extração de cálcio pelas folhas (mg.planta $\left.{ }^{-1}\right)$ em função dos níveis de alumínio estudados (mg. $\left.\mathrm{L}^{-1}\right)$, dentro de cada cultivar (médias de quatro repetições).

\begin{tabular}{|c|c|c|c|c|c|c|c|}
\hline \multirow[t]{2}{*}{ Cultivares } & \multicolumn{6}{|c|}{ Alumínio (mg. $\mathrm{L}^{-1}$ ) } & \multirow[t]{2}{*}{ Médias } \\
\hline & 0 & 10 & 20 & 30 & 40 & 50 & \\
\hline 525 & $40,71 \mathrm{ABab}$ & $52,52 \mathrm{Aa}$ & $29,53 \mathrm{ABbc}$ & $28,84 \mathrm{Abc}$ & 17,91 Acd & $11,01 \mathrm{Ad}$ & $30,09 \mathrm{~A}$ \\
\hline 135 & $52,53 \mathrm{Aa}$ & $36,89 \mathrm{BCb}$ & $30,43 \mathrm{ABb}$ & $12,82 \mathrm{Bc}$ & $14,31 \mathrm{Ac}$ & $8,55 \mathrm{Ac}$ & $25,87 \mathrm{~B}$ \\
\hline 125 & $40,23 \mathrm{ABa}$ & $40,65 \mathrm{ABa}$ & $40,93 \mathrm{Aa}$ & $20,17 \mathrm{ABb}$ & $13,69 \mathrm{Ab}$ & $10,66 \mathrm{Ab}$ & $27,72 \mathrm{~A}$ \\
\hline 805 & $34,50 \mathrm{BCa}$ & 23,79 CDab & 21,08 BCab & $15,97 \mathrm{ABb}$ & $14,99 \mathrm{Ab}$ & $12,28 \mathrm{Ab}$ & 20,43 B \\
\hline 701 & $25,43 \mathrm{Ca}$ & $24,33 \mathrm{CDa}$ & $14,16 \mathrm{Cab}$ & $7,85 \mathrm{Bb}$ & $4,75 \mathrm{Ab}$ & $7,23 \mathrm{Ab}$ & $13,96 \mathrm{C}$ \\
\hline 425 & $25,27 \mathrm{Ca}$ & 16,45 Dab & $15,46 \mathrm{Cab}$ & $13,03 \mathrm{Bab}$ & $7,75 \mathrm{Ab}$ & $6,05 \mathrm{Ab}$ & $14,00 \mathrm{C}$ \\
\hline Médias & $36,44 a$ & $32,39 \mathrm{a}$ & $25,26 \mathrm{~b}$ & $16,45 \mathrm{c}$ & $12,23 \mathrm{~cd}$ & $9,29 \mathrm{~d}$ & 22,01 \\
\hline
\end{tabular}

- Médias seguidas por letras iguais, maiúsculas na vertical ou minúsculas na horizontal, não diferem entre si pelo teste de Tukey ao nivel de $5 \%$ de probabilidade. 


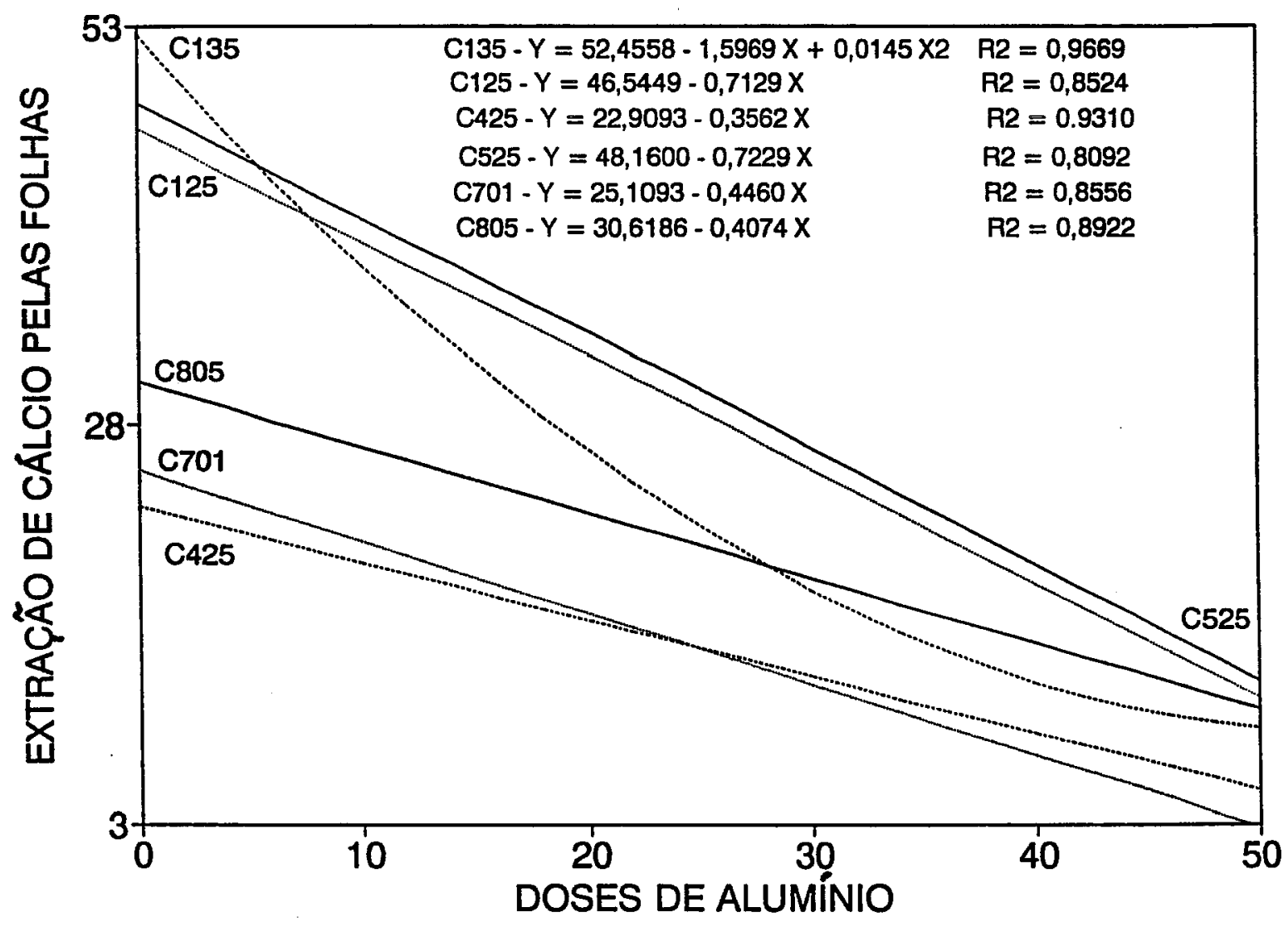

Figura 13. Regressões entre a extração de cálcio pelas folhas (g.planta-1) e os níveis de alumínio (mg. $\mathrm{L}^{\mathbf{- 1}}$ ) para os seis cultivares estudados. 
A Tabela 26 apresenta a extração de cálcio pelas raízes (mg. planta-1) em função dos níveis de alumínio estudados (mg.L-1), dentro de cada cultivar. Observa-se que dos cultivares estudados, somente C525, C135 e C125 apresentaram redução na extração de cálcio pelas raízes com o aumento da concentração de alumínio da solução, reduzindo gradativamente a extração de cálcio pelas raízes com o aumento do nível alumínio na solução.

O comportamento da extração de cálcio pelas raízes em cada cultivar, em função dos níveis de alumínio aplicados, é apresentado na Figura 14, onde são representadas as regressões entre a extração de cálcio pelas raízes (mg.planta ${ }^{-1}$ ) e as doses de alumínio (mg.L $\mathrm{L}^{\mathbf{1}}$ ), para os seis cultivares estudados. Assim, todas as regressões representam a redução da extração pelas raízes em função dos níveis de alumínio, porém os cultivares C425, C701 e C805 apresentaram reduções representadas por equações lineares, enquanto os demais cultivares apresentaram reduções representadas por equações quadráticas, com mínimos em 30,$1 ; 45,7$ e 50,3 mg.L $\mathrm{L}^{-1}$ de alumínio para os cultivares C525, C125 e C135, respectivamente.

Na Tabela 26 observa-se que, na ausência de alumínio, o cultivar C525 apresentou extração de cálcio pelas raízes significativamente maior que os demais cultivares. $O$ nível $20 \mathrm{mg} . \mathrm{L}^{-1}$ foi o que melhor diferenciou os cultivares quanto ao seu comportamento em relação ao alumínio. Assim, nesse nível, os cultivares C525, C135 e C125 apresentaram as maiores extrações de cálcio pelas raízes, diferindo significativamente dos cultivares C701 e C425 e não diferindo do cultivar C805.

A Tabela 27 apresenta a extração de cálcio pelos colmos (mg.

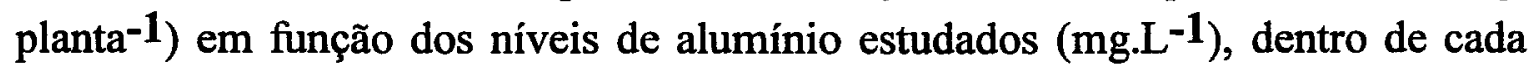
cultivar. Observa-se que os cultivares estudados, embora tenham todos apresentado redução na extração de cálcio pelas folhas com o aumento da concentração de alumínio da solução, apresentaram comportamentos diversos em relação aos níveis de alumínio. Assim, os cultivares C135, C125 e C425apresentaram redução significativa na extração de cálcio pelos colmos a partir de $30 \mathrm{mg} . \mathrm{L}^{\mathbf{1}}$ de alumínio na solução; os cultivares C525 e C701 praticamente não apresentaram redução significativa na extração pelos colmos com até $10 \mathrm{mg} . \mathrm{L}^{\mathbf{- 1}}$ de alumínio na solução e o cultivar C805 apresentou redução na extração de cálcio pelos colmos somente no nível $10 \mathrm{mg} . \mathrm{L}^{\mathbf{- 1}}$. 
Tabela 26. Extração de cálcio pelas raízes (mg.planta ${ }^{-1}$ ) em função dos níveis de alumínio estudados (ppm), dentro de cada cultivar (médias de quatro repetições).

\begin{tabular}{|c|c|c|c|c|c|c|c|}
\hline \multirow[t]{2}{*}{ Cultivares } & \multicolumn{6}{|c|}{ Alumínio (mg. $\mathrm{L}^{-1}$ ) } & \multirow[t]{2}{*}{ Médias } \\
\hline & 0 & 10 & 20 & 30 & 40 & 50 & \\
\hline 525 & $111,90 \mathrm{Aa}$ & $31,59 \mathrm{Ab}$ & $25,56 \mathrm{Abc}$ & $24,04 \mathrm{Abc}$ & 14,47 Acd & $7,42 \mathrm{Ad}$ & $35,83 \mathrm{~A}$ \\
\hline 135 & $53,69 \mathrm{Ba}$ & $33,29 \mathrm{Ab}$ & $25,68 \mathrm{Abc}$ & $18,36 \mathrm{ABcd}$ & $12,62 \mathrm{Acd}$ & $9,21 \mathrm{Ad}$ & $25,48 \mathrm{~B}$ \\
\hline 125 & $62,85 \mathrm{Ba}$ & $29,45 \mathrm{Ab}$ & $31,15 \mathrm{Ab}$ & $17,59 \mathrm{ABbc}$ & $9,17 \mathrm{Ac}$ & $10,10 \mathrm{Ac}$ & $26,72 \mathrm{~B}$ \\
\hline 805 & $16,97 \mathrm{Ca}$ & $15,23 \mathrm{Ba}$ & $17,80 \mathrm{ABa}$ & $13,19 \mathrm{ABCa}$ & $13,09 \mathrm{Aa}$ & $8,15 \mathrm{Aa}$ & $14,07 \mathrm{C}$ \\
\hline 701 & $11,82 \mathrm{Ca}$ & $6,95 \mathrm{Ba}$ & $5,21 \mathrm{Ba}$ & $3,16 \mathrm{Ca}$ & $1,90 \mathrm{Aa}$ & $2,85 \mathrm{Aa}$ & $5,31 \mathrm{D}$ \\
\hline 425 & $13,71 \mathrm{Ca}$ & $8,69 \mathrm{Ba}$ & $6,39 \mathrm{Ba}$ & 7,58 $\mathrm{BCa}$ & $3,28 \mathrm{Aa}$ & 4,70 Aa & $7,39 \mathrm{D}$ \\
\hline Médias & $45,16 \mathrm{a}$ & $20,86 \mathrm{~b}$ & $18,63 \mathrm{bc}$ & $13,98 \mathrm{~cd}$ & $9,09 \mathrm{de}$ & $7,07 \mathrm{e}$ & 19,13 \\
\hline
\end{tabular}

- Médias seguidas por letras iguais, maiúsculas na vertical ou minúsculas na horizontal, não diferem entre si pelo teste de Tukey ao nível de $5 \%$ de probabilidade. 


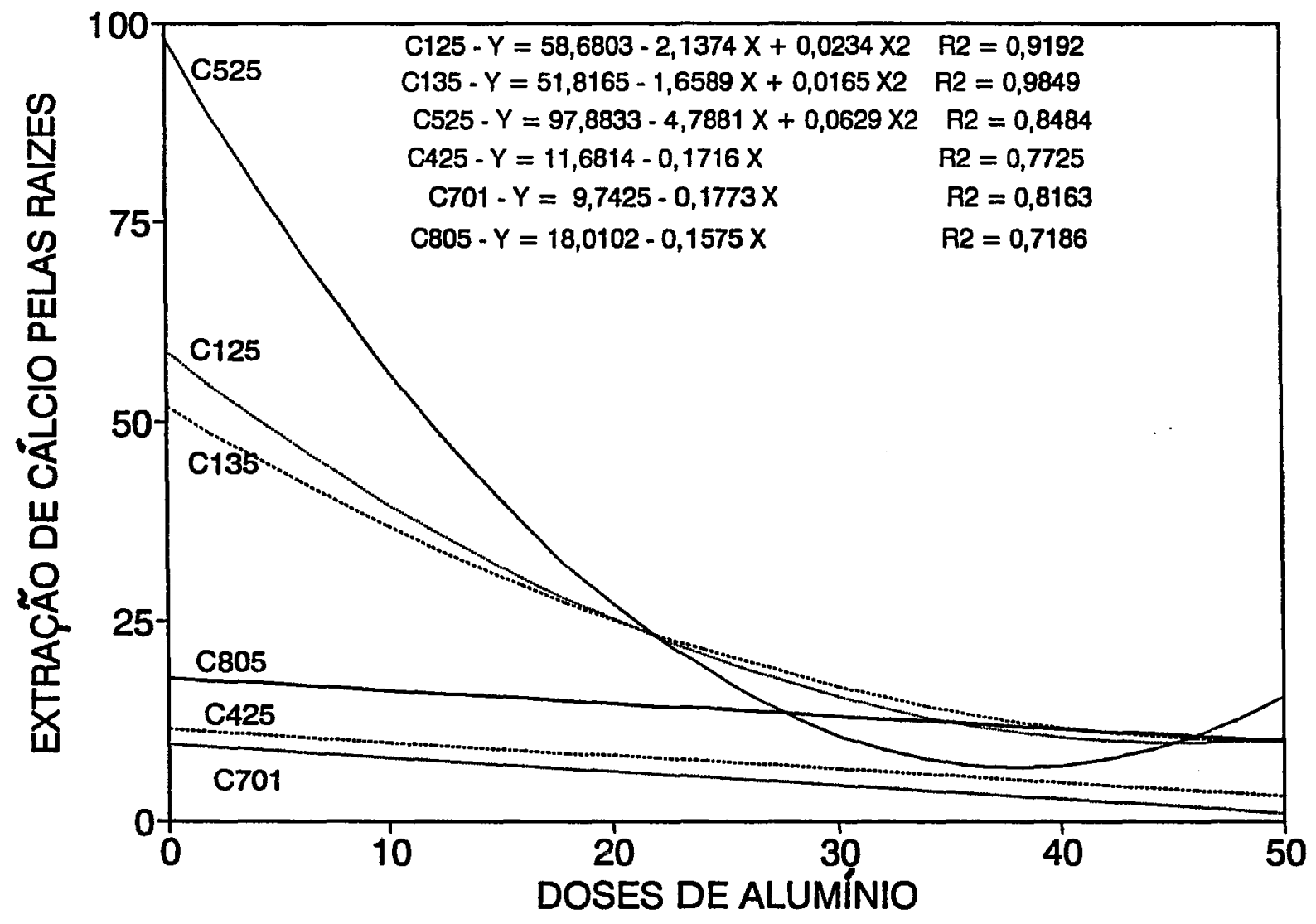

Figura 14. Regressões entre a extração de cálcio pelas raízes (g.planta-1) e os níveis de alumínio (mg.L-1) para os seis cultivares estudados. 
Tabela 27. Extração de cálcio pelos colmos (mg.planta $\left.{ }^{-1}\right)$ em função dos níveis de alumínio estudados $\left(\mathrm{mg} \cdot \mathrm{L}^{-1}\right)$, dentro de cada cultivar (médias de quatro repetições).

\begin{tabular}{|c|c|c|c|c|c|c|c|}
\hline \multirow[t]{2}{*}{ Cultivares } & \multicolumn{6}{|c|}{ Alumínio (mg. $\mathrm{L}^{-1}$ ) } & \multirow[t]{2}{*}{ Médias } \\
\hline & 0 & 10 & 20 & 30 & 40 & 50 & \\
\hline 525 & $42,22 \mathrm{Ab}$ & $62,32 \mathrm{Aa}$ & $25,30 \mathrm{BCc}$ & 16,03 Acd & 6,58 Ad & 4,69 Ad & $26,19 \mathrm{~A}$ \\
\hline 135 & $42,13 \mathrm{Aa}$ & $39,79 \mathrm{Ba}$ & $34,62 \mathrm{ABa}$ & $10,85 \mathrm{Ab}$ & $8,65 \mathrm{Ab}$ & $6,07 \mathrm{Ab}$ & $23,69 \mathrm{~A}$ \\
\hline 125 & $40,54 \mathrm{Aa}$ & $42,40 \mathrm{Ba}$ & $41,71 \mathrm{Aa}$ & $13,55 \mathrm{Ab}$ & $7,84 \mathrm{Ab}$ & $8,31 \mathrm{Ab}$ & $25,72 \mathrm{~A}$ \\
\hline 805 & $34,49 \mathrm{ABa}$ & $18,18 \mathrm{Cb}$ & $14,01 \mathrm{Db}$ & $8,19 \mathrm{Ab}$ & $12,21 \mathrm{Ab}$ & $8,15 \mathrm{Ab}$ & $15,87 \mathrm{~B}$ \\
\hline 701 & $22,82 \mathrm{Ba}$ & $13,89 \mathrm{Cab}$ & $8,37 \mathrm{Db}$ & $5,14 \mathrm{Ab}$ & $2,09 \mathrm{Ab}$ & $3,69 \mathrm{Ab}$ & $9,33 \mathrm{~B}$ \\
\hline 425 & $17,88 \mathrm{Ca}$ & $14,09 \mathrm{Ca}$ & $14,15 \mathrm{CDa}$ & $7,87 \mathrm{Ab}$ & 8,97 Aa & $5,49 \mathrm{Aa}$ & $11,41 \mathrm{~B}$ \\
\hline Médias & $33,34 \mathrm{a}$ & $31,78 \mathrm{a}$ & $23,03 \mathrm{~b}$ & $10,27 c$ & $7,72 \mathrm{c}$ & $6,07 \mathrm{c}$ & 18,7 \\
\hline
\end{tabular}

- Médias seguidas por letras iguais, maiúsculas na vertical ou minúsculas na horizontal, não diferem entre si pelo teste de Tukey ao nível de $5 \%$ de probabilidade. 
O comportamento da extração de cálcio pelos colmos em cada cultivar, em função dos níveis de alumínio aplicados, é apresentado na Figura 15, onde são apresentadas as equações de regressão entre a extração de cálcio pelos colmos (mg.planta-1) e os níveis de alumínio (mg.L ${ }^{-1}$ ), dos seis cultivares estudados. Assim, todas as regressões representam a redução da extração de cálcio pelos colmos em função dos níveis de alumínio, porém os cultivares $\mathrm{C} 125$, C425, C525 e C701 apresentaram reduções representadas por equações lineares, enquanto o cultivar C805 apresentou redução representada por uma equação quadrática, com mínimo em $38,2 \mathrm{mg} . \mathrm{L}^{-1}$ de alumínio.

Na Tabela 27 observa-se que, na ausência de alumínio, os cultivares C525, C135 e C125 apresentaram extrações de cálcio pelos colmos significativamente maiores que os demais, exceto o cultivar C805. Com o aumento do nível de alumínio da solução, os cultivares C525, C125 e C135 apresentaram as maiores extrações de cálcio.

A Tabela 28 apresenta a extração de cálcio (mg.planta ${ }^{-1}$ ) das partes amostradas dentro de cada cultivar, para os níveis 0 e $10 \mathrm{mg} . \mathrm{L}^{-1}$ de alumínio na solução. Observa-se que na ausência de alumínio, os cultivares já apresentavam comportamentos diferentes em relação à extração de cálcio pelas três partes amostradas. Assim, os cultivares C135, C701 e C425 apresentavam extrações de cálcio semelhantes para as três partes amostradas, enquanto o cultivar C525 apresentou extração pelas folhas e colmos menores que as das raízes; o cultivar C125 apresentava extração pelas folhas significativamente maior que a das demais partes amostradas e para o cultivar C805 as maiores extrações foram das folhas e dos colmos. Ainda na ausência de alumínio, quanto à extração de cálcio pelas folhas, o cultivar $\mathrm{C} 135$ apresentou valores significativamente maiores que os demais cultivares, exceto os cultivares C525 e C125 dos quais não diferiu; quanto à extração de cálcio pelas raízes, o cultivar C525 diferiu dos demais; quanto à extração de cálcio pelos colmos, os cultivares 525, C135 e C125 diferiram dos demais cultivares, exceto do cultivar C805 do qual não diferiram estatisticamente.

No nível 10 mg.L-1 de alumínio, observa-se que os cultivares também apresentavam comportamentos diversos em relação à extração de cálcio pelas três partes amostradas. Assim, os cultivares C135, C125, C805 e C425 apresentavam as três partes amostradas com extrações estatisticamente 


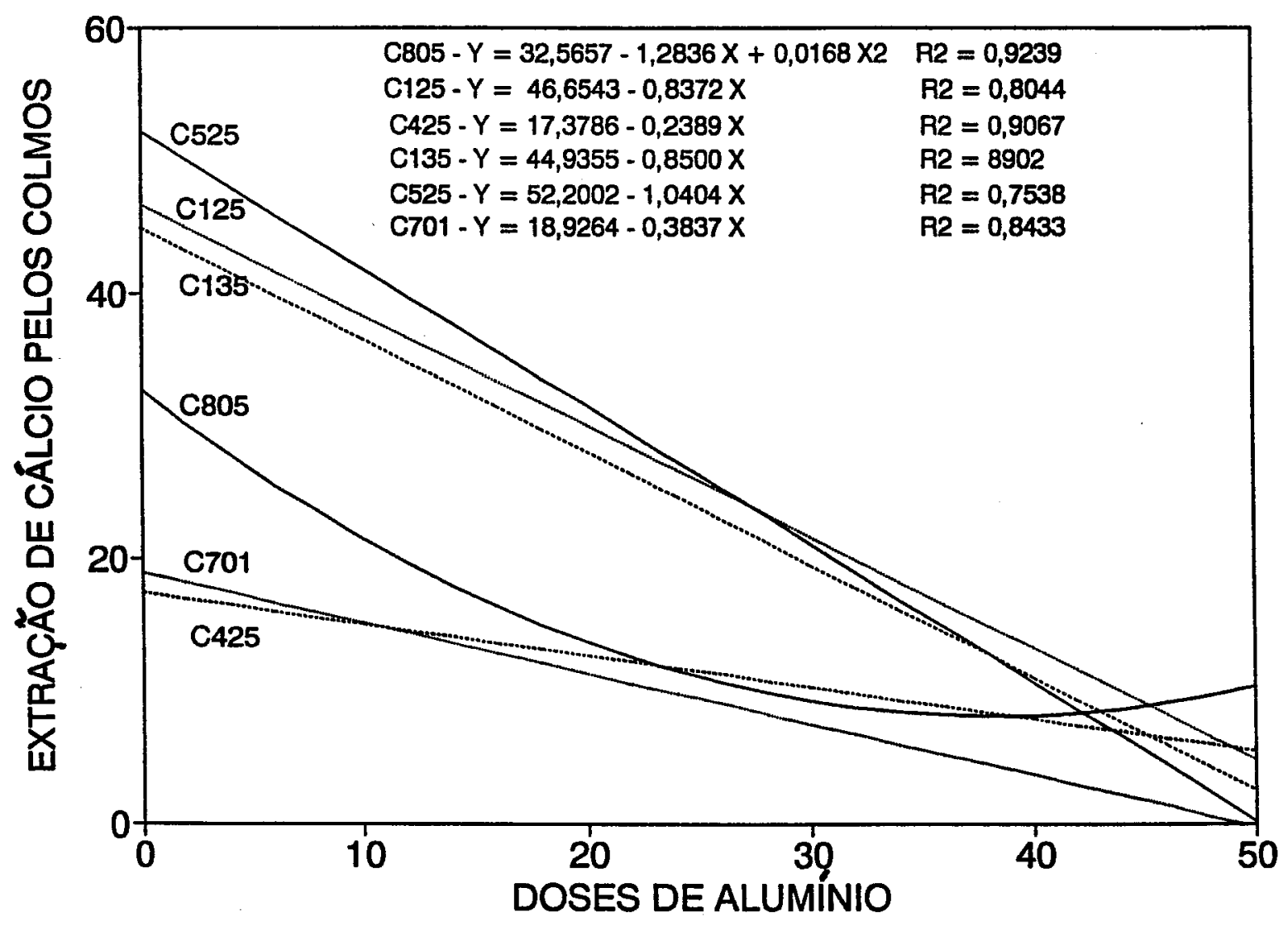

Figura 15. Regressões entre a extração de cálcio pelos colmos (g.planta-1) e os níveis de alumínio (mg. $\mathrm{L}^{\mathbf{- 1}}$ ) para os seis cultivares estudados. 
Tabela 28: Extração de cálcio (mg.planta ${ }^{-1}$ ) em função das partes amostradas, dentro de cada cultivar, para os níveis 0 e $10 \mathrm{mg} . \mathrm{L}^{-1}$ de alumínio (médias de quatro repetições).

\begin{tabular}{|c|c|c|c|c||}
\hline \multirow{2}{*}{ Cultivares } & \multicolumn{5}{|c|}{ Nivel 0 de Alumínio } \\
\cline { 2 - 5 } & Folhas & Raízes & Colmos & Médias \\
\hline 525 & $40,71 \mathrm{ABb}$ & $111,90 \mathrm{Aa}$ & $42,22 \mathrm{Ab}$ & $64,94 \mathrm{~A}$ \\
\hline 135 & $52,53 \mathrm{Aa}$ & $53,69 \mathrm{Ba}$ & $42,13 \mathrm{Aa}$ & $49,95 \mathrm{~B}$ \\
\hline 125 & $40,23 \mathrm{ABa}$ & $62,85 \mathrm{Bb}$ & $40,54 \mathrm{Ab}$ & $47,87 \mathrm{~B}$ \\
\hline 805 & $34,50 \mathrm{BCa}$ & $16,97 \mathrm{Cb}$ & $34,49 \mathrm{ABa}$ & $28,65 \mathrm{C}$ \\
\hline 701 & $25,43 \mathrm{Ca}$ & $11,81 \mathrm{Ca}$ & $22,82 \mathrm{Ba}$ & $20,02 \mathrm{C}$ \\
\hline 425 & $25,27 \mathrm{Ca}$ & $13,71 \mathrm{Ca}$ & $17,87 \mathrm{Ca}$ & $18,95 \mathrm{C}$ \\
\hline Médias & $36,44 \mathrm{~b}$ & $45,16 \mathrm{a}$ & $33,35 \mathrm{~b}$ & 38,31 \\
\hline & & Nível $10 \mathrm{de} \mathrm{Aluminio}$ & \\
\hline 525 & $52,52 \mathrm{Aa}$ & $31,58 \mathrm{Ab}$ & $62,32 \mathrm{Aa}$ & $48,81 \mathrm{~A}$ \\
\hline 135 & $36,59 \mathrm{Ba}$ & $33,29 \mathrm{Aa}$ & $39,79 \mathrm{Ba}$ & $36,55 \mathrm{~A}$ \\
\hline 125 & $40,65 \mathrm{ABa}$ & $29,45 \mathrm{Aa}$ & $42,40 \mathrm{Ba}$ & $37,50 \mathrm{~A}$ \\
\hline 805 & $23,79 \mathrm{Ca}$ & $15,23 \mathrm{Ba}$ & $18,17 \mathrm{Ca}$ & $19,06 \mathrm{~B}$ \\
\hline 701 & $24,33 \mathrm{Ca}$ & $6,95 \mathrm{Bb}$ & $13,89 \mathrm{Cab}$ & $15,06 \mathrm{~B}$ \\
\hline 425 & $16,45 \mathrm{Ca}$ & $8,69 \mathrm{Ba}$ & $14,10 \mathrm{Ca}$ & $13,08 \mathrm{~B}$ \\
\hline Médias & $32,39 \mathrm{Ca}$ & $20,86 \mathrm{a}$ & $31,78 \mathrm{a}$ & 28,34 \\
\hline
\end{tabular}

- Médias seguidas por letras iguais, maiúsculas na vertical ou minúsculas na horizontal, dentro de cada nível de alumínio, não diferem entre si pelo teste de Tukey ao nível de $5 \%$ de probabilidade 
semelhantes, enquanto o cultivar C525 apresentava extrações de cálcio pelas folhas e pelos colmos superior à das raízes, o cultivar C701 apresentou extração de cálcio pelas raizes menor que a extrações pelas folhas. Ainda no nível $10 \mathrm{mg}$. $\mathrm{L}^{\mathbf{- 1}}$ de alumínio, quanto à extração de cálcio pelas folhas, o cultivar C525 apresentou valores significativamente maiores que os demais cultivares, exceto o cultivar C125; quanto à extração pelas raizes, os cultivares C525, C135 e C125 diferiram dos demais cultivares; quanto à extração de cálcio pelos colmos, o cultivar C525 diferiu dos demais cultivares.

A Tabela 29 apresenta a extração de cálcio (mg.planta-1) das partes amostradas dentro de cada cultivar, para os níveis 20 e $30 \mathrm{mg} . \mathrm{L}^{-1}$ de alumínio na solução. Observa-se que no nível $20 \mathrm{mg} . \mathrm{L}^{\mathbf{- 1}}$ de alumínio, os cultivares apresentaram extrações de cálcio que não diferiram significativamente nas três partes amostradas. Ainda no nível $20 \mathrm{mg} . \mathrm{L}^{\mathbf{- 1}}$ de alumínio, quanto à extração de cálcio pelas folhas, o cultivar C125 diferiu dos demais, exceto dos cultivares C525 e C135; quanto à extração de cálcio pelas raízes, os cultivares C525, C135 e C125 diferiram dos demais cultivares, exceto do cultivar C805; quanto à extração de cálcio pelos colmos, o cultivar C125 diferiu dos demais, exceto do cultivar C135.

No nível $30 \mathrm{mg} . \mathrm{L}^{-1}$ de alumínio, observa-se que os cultivares também não apresentavam diferenças significativas quanto à extração de cálcio pelas três partes amostradas. Ainda no nível $30 \mathrm{mg} . \mathrm{L}^{-1}$ de alumínio, quanto à extração de cálcio pelas folhas, o cultivar C525 apresentou valores significativamente maiores que os demais cultivares, exceto os cultivares C125 e C805; quanto à extração pelas raízes, o cultivar C525 não diferiu dos cultivares C135, C125 e C805, diferindo dos demais, quanto à extração pelos colmos, os cultivares não diferiram entre si.

A Tabela 30 apresenta a extração de cálcio (mg.planta-1) das partes amostradas dentro de cada cultivar, para os níveis 40 e $50 \mathrm{mg} . \mathrm{L}^{\mathbf{- 1}}$ de alumínio na solução. Observa-se que nos níveis 40 e $50 \mathrm{mg} . \mathrm{L}-1$ de alumínio, os cultivares não apresentam diferenças quanto à extração de cálcio pelas três partes amostradas dentro de cada cultivar nem quanto aos cultivares dentro das partes amostradas 
Tabela 29: Extração de cálcio (mg.planta ${ }^{-1}$ ) em função das partes amostradas, dentro de cada cultivar, para os níveis 20 e $30 \mathrm{mg} . \mathrm{L}^{-1}$ de alumínio (médias de quatro repetições).

\begin{tabular}{|c|c|c|c|c||}
\hline \multirow{2}{*}{ Cultivares } & \multicolumn{5}{|c|}{ Nível 20 de Alumínio } \\
\cline { 2 - 5 } & Folhas & Raízes & Colmos & Médias \\
\hline 525 & $29,53 \mathrm{ABa}$ & $25,56 \mathrm{Aa}$ & $25,30 \mathrm{BCa}$ & $26,80 \mathrm{~B}$ \\
\hline 135 & $30,43 \mathrm{ABa}$ & $25,68 \mathrm{Aa}$ & $34,62 \mathrm{ABa}$ & $30,24 \mathrm{~B}$ \\
\hline 125 & $40,93 \mathrm{Aa}$ & $31,15 \mathrm{Aa}$ & $41,71 \mathrm{Aa}$ & $37,93 \mathrm{~A}$ \\
\hline 805 & $21,08 \mathrm{Ba}$ & $17,80 \mathrm{ABa}$ & $14,01 \mathrm{CDa}$ & $17,63 \mathrm{C}$ \\
\hline 701 & $14,16 \mathrm{Ca}$ & $5,21 \mathrm{Ba}$ & $8,37 \mathrm{Da}$ & $9,25 \mathrm{D}$ \\
\hline 425 & $15,46 \mathrm{Ca}$ & $6,39 \mathrm{Ba}$ & $14,15 \mathrm{CDa}$ & $12,00 \mathrm{D}$ \\
\hline Médias & $25,27 \mathrm{a}$ & $18,63 \mathrm{~b}$ & $23,03 \mathrm{a}$ & 22,31 \\
\hline & & Nível $30 \mathrm{de} \mathrm{Alumínio}$ & \\
\hline 525 & $28,84 \mathrm{Aa}$ & $24,03 \mathrm{Aa}$ & $16,03 \mathrm{Aa}$ & $22,97 \mathrm{~A}$ \\
\hline 135 & $12,82 \mathrm{Ba}$ & $18,36 \mathrm{ABa}$ & $10,85 \mathrm{Aa}$ & $14,01 \mathrm{BC}$ \\
\hline 125 & $20,17 \mathrm{ABa}$ & $17,59 \mathrm{ABa}$ & $13,55 \mathrm{Aa}$ & $17,10 \mathrm{~B}$ \\
\hline 805 & $15,97 \mathrm{ABa}$ & $13,19 \mathrm{ABCa}$ & $8,19 \mathrm{Aa}$ & $12,45 \mathrm{BC}$ \\
\hline 701 & $7,85 \mathrm{Ba}$ & $3,16 \mathrm{Ca}$ & $5,14 \mathrm{Aa}$ & $5,38 \mathrm{D}$ \\
\hline 425 & $13,03 \mathrm{Ba}$ & $7,58 \mathrm{BCa}$ & $7,87 \mathrm{Aa}$ & $9,50 \mathrm{CD}$ \\
\hline Médias & $16,45 \mathrm{a}$ & $13,98 \mathrm{ab}$ & $10,27 \mathrm{~b}$ & 13,57 \\
\hline \hline
\end{tabular}

- Médias seguidas por letras iguais, maiúsculas na vertical ou minúsculas na horizontal, dentro de cada nível de alumínio, não diferem entre si pelo teste de Tukey ao nível de $5 \%$ de probabilidade 
Tabela 30: Extração de cálcio (mg.planta $\left.{ }^{-1}\right)$ em função das partes amostradas, dentro de cada cultivar, para os níveis 40 e $50 \mathrm{mg} . \mathrm{L}^{-1}$ de alumínio (médias de quatro repetições).

\begin{tabular}{|c|c|c|c|c||}
\hline \multirow{2}{*}{ Cultivares } & \multicolumn{5}{|c|}{ Nível 40 de Alumínio } \\
\cline { 2 - 6 } & Folhas & Raízes & Colmos & Médias \\
\hline 525 & $17,91 \mathrm{Aa}$ & $14,47 \mathrm{Aa}$ & $6,58 \mathrm{Aa}$ & $12,99 \mathrm{~A}$ \\
\hline 135 & $14,31 \mathrm{Aa}$ & $12,62 \mathrm{Aa}$ & $8,65 \mathrm{Aa}$ & $11,86 \mathrm{~A}$ \\
\hline 125 & $13,69 \mathrm{Aa}$ & $9,17 \mathrm{Aa}$ & $7,84 \mathrm{Aa}$ & $10,23 \mathrm{~A}$ \\
\hline 805 & $14,99 \mathrm{Aa}$ & $13,09 \mathrm{Aa}$ & $12,21 \mathrm{Aa}$ & $13,43 \mathrm{~A}$ \\
\hline 701 & $4,75 \mathrm{Aa}$ & $1,89 \mathrm{Aa}$ & $2,09 \mathrm{Aa}$ & $2,91 \mathrm{C}$ \\
\hline 425 & $7,75 \mathrm{Aa}$ & $3,28 \mathrm{Aa}$ & $8,97 \mathrm{Aa}$ & $6,67 \mathrm{~B}$ \\
\hline Médias & $12,23 \mathrm{a}$ & $9,09 \mathrm{~b}$ & $7,72 \mathrm{~b}$ & 9,68 \\
\hline & & Nível $50 \mathrm{de} \mathrm{Alumíni}$ & \\
\hline 525 & $11,01 \mathrm{Aa}$ & $7,42 \mathrm{Aa}$ & $4,69 \mathrm{Aa}$ & $7,71 \mathrm{AB}$ \\
\hline 135 & $8,55 \mathrm{Aa}$ & $9,21 \mathrm{Aa}$ & $6,07 \mathrm{Aa}$ & $7,94 \mathrm{~A}$ \\
\hline 125 & $10,66 \mathrm{Aa}$ & $10,10 \mathrm{Aa}$ & $8,31 \mathrm{Aa}$ & $9,69 \mathrm{~A}$ \\
\hline 805 & $12,28 \mathrm{Aa}$ & $7,42 \mathrm{Aa}$ & $4,69 \mathrm{Aa}$ & $9,53 \mathrm{~A}$ \\
\hline 701 & $7,23 \mathrm{Aa}$ & $2,85 \mathrm{Aa}$ & $3,69 \mathrm{Aa}$ & $4,59 \mathrm{C}$ \\
\hline 425 & $6,05 \mathrm{Aa}$ & $4,70 \mathrm{Aa}$ & $5,49 \mathrm{Aa}$ & $5,41 \mathrm{BC}$ \\
\hline Médias & $9,29 \mathrm{a}$ & $7,07 \mathrm{~b}$ & $6,07 \mathrm{~b}$ & 7,47 \\
\hline \hline
\end{tabular}

- Médias seguidas por letras iguais, maiúsculas na vertical ou minúsculas na horizontal, dentro de cada nível de alumínio, não diferem entre si pelo teste de Tukey ao nível de $5 \%$ de probabilidade 


\subsection{Extração de magnésio}

A Tabela 31 apresenta a extração de magnésio pelas folhas (mg.planta-1) em função dos níveis de alumínio estudados (mg.L ${ }^{-1}$ ), dentro de cada cultivar. Observa-se que os cultivares, embora tenham todos apresentado redução na extração de magnésio pelas folhas com o aumento da concentração de alumínio da solução, apresentaram comportamentos diversos em relação aos níveis de alumínio. Assim, os cultivares C135, C125, C805, C701 e C425 não apresentaram estatisticamente redução na extração de magnésio pelas folhas com até $20 \mathrm{mg} . \mathrm{L}^{-1}$ de alumínio na solução, reduzindo sua extração somente em 30 mg.L-1 e o cultivar C525 não apresentou redução na extração pelas folhas até 10 mg.L $\mathbf{H}^{-1}$.

O comportamento da extração de magnésio pelas folhas em cada cultivar, em função dos níveis de alumínio aplicados, é apresentado na Figura 16, onde são representadas as equações de regressão entre a extração de magnésio pelas folhas (mg.planta-1) e as doses de aluminio (mg.L ${ }^{-1}$ ), para os seis cultivares estudados. Assim, todas as regressões representam a redução da extração de magnésio pelas folhas em função dos níveis de alumínio, porém os cultivares C425, C135, C701 e C805 apresentaram reduções representadas por equações lineares, enquanto os cultivares $\mathrm{C125}$ e $\mathrm{C525}$ apresentaram reduções representadas por equações quadráticas, com máximos em 5,4 e $7,1 \mathrm{mg} . \mathrm{L}^{-1}$ de alumínio.

Na Tabela 31 observa-se que, na ausência de alumínio o cultivar C135 apresentou extração de magnésio pelas folhas significativamente maior que os demais, exceto os cultivares C525, C125 e C805. Com o aumento do nível de alumínio da solução, o cultivar C525 apresentou extração de magnésio pelas folhas maior que os demais cultivares.

A Tabela 32 apresenta a extração de magnésio pelas raízes (mg.planta-1) em função dos níveis de alumínio estudados (mg.L ${ }^{-1}$ ), dentro de cada cultivar. Observa-se que os cultivares, embora tenham todos apresentado redução na extração de magnésio pelas raízes com o aumento da concentração de alumínio da solução, apresentaram comportamentos diversos em relação aos níveis de alumínio. Assim, os cultivares C525, C135, C125 e C425 apresentaram redução na extração de magnésio pelas raizes somente a partir de $30 \mathrm{mg} . \mathrm{L}^{\mathbf{- 1}}$, 
Tabela 31. Extração de magnésio pelas folhas (mg.planta ${ }^{-1}$ ) em função dos níveis de alumínio estudados (mg. $\mathrm{L}^{-1}$ ), dentro de cada cultivar (médias de quatro repetições).

\begin{tabular}{|c|c|c|c|c|c|c|c|}
\hline \multirow[t]{2}{*}{ Cultivares } & \multicolumn{6}{|c|}{ Alumínio (mg. $\mathrm{L}^{-1}$ ) } & \multirow[t]{2}{*}{ Médias } \\
\hline & 0 & 10 & 20 & 30 & 40 & 50 & \\
\hline 525 & $19,71 \mathrm{ABb}$ & $34,96 \mathrm{Aa}$ & $18,51 \mathrm{ABb}$ & $12,76 \mathrm{Abc}$ & 9,37 Ac & $6,86 \mathrm{Ac}$ & $17,03 \mathrm{~A}$ \\
\hline 135 & $23,71 \mathrm{Aa}$ & $20,75 \mathrm{Ba}$ & $18,65 \mathrm{ABa}$ & $8,50 \mathrm{Ab}$ & $6,56 \mathrm{Ab}$ & $5,55 \mathrm{Ab}$ & $13,95 \mathrm{~A}$ \\
\hline 125 & $17,21 \mathrm{ABab}$ & 18,79 BCab & $22,20 \mathrm{Aa}$ & $11,53 \mathrm{Abc}$ & $8,27 \mathrm{Ac}$ & $7,94 \mathrm{Ac}$ & $14,32 \mathrm{~A}$ \\
\hline 805 & $16,86 \mathrm{ABa}$ & $10,56 \mathrm{Cab}$ & 10,45 BCab & $7,21 \mathrm{Ab}$ & $6,82 \mathrm{Ab}$ & $5,43 \mathrm{Ab}$ & $9,55 \mathrm{~B}$ \\
\hline 701 & $13,11 \mathrm{Ba}$ & $10,96 \mathrm{Cab}$ & 6,98 Cab & $4,73 \mathrm{Ab}$ & $2,87 \mathrm{Ab}$ & 4,81 Aab & $7,24 \mathrm{~B}$ \\
\hline 425 & $14,92 \mathrm{Ba}$ & $10,53 \mathrm{Cab}$ & $7,25 \mathrm{Cab}$ & $6,55 \mathrm{Ab}$ & $4,57 \mathrm{Ab}$ & $5,47 \mathrm{Ab}$ & $8,21 \mathrm{~B}$ \\
\hline Médias & $17,59 \mathrm{a}$ & $17,76 \mathrm{a}$ & $14,00 \mathrm{~b}$ & $8,55 \mathrm{c}$ & $6,41 \mathrm{c}$ & $6,01 \mathrm{c}$ & 11,72 \\
\hline
\end{tabular}

- Médias seguidas por letras iguais, maiúsculas na vertical ou minúsculas na horizontal, não diferem entre si pelo teste de Tukey ao nivel de $5 \%$ de probabilidade. 


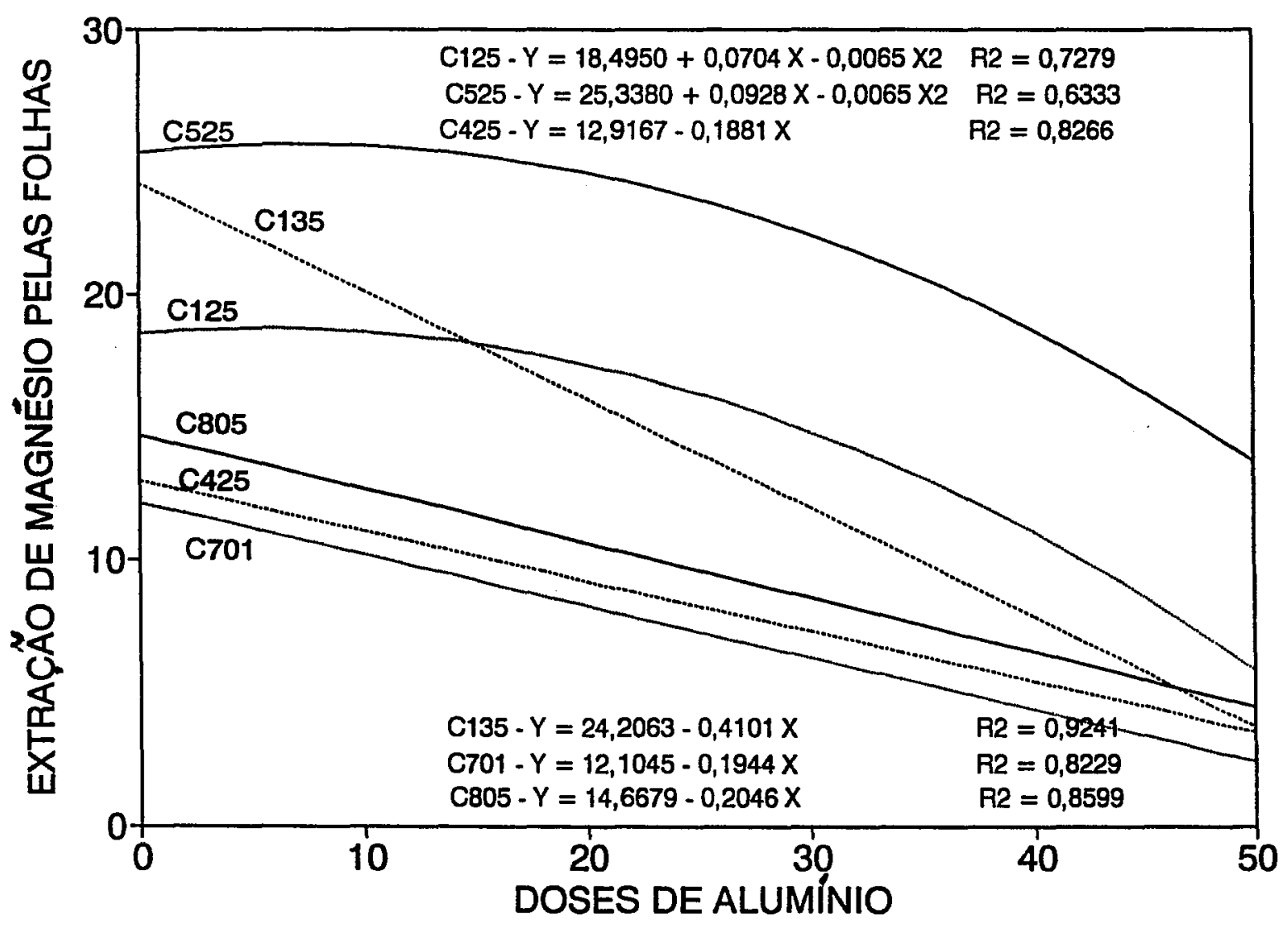

Figura 16. Regressões entre a extração de magnésio pelas folhas (g.planta-1) e os níveis de alumínio (mg. $\mathrm{L}^{-1}$ ) para os seis cultivares estudados. 
Tabela 32. Extração de magnésio pelas raízes (mg.planta ${ }^{-1}$ ) em função dos níveis de alumínio estudados (mg. $\mathrm{L}^{-1}$ ), dentro de cada cultivar (médias de quatro repetições).

\begin{tabular}{|c|c|c|c|c|c|c|c|}
\hline \multirow[t]{2}{*}{ Cultivares } & \multicolumn{6}{|c|}{ Alumínio (mg. $\mathrm{L}^{-1}$ ) } & \multirow[t]{2}{*}{ Médias } \\
\hline & 0 & 10 & 20 & 30 & 40 & 50 & \\
\hline 525 & $20,39 \mathrm{ABa}$ & $20,25 \mathrm{Aa}$ & $16,21 \mathrm{ABab}$ & $10,64 \mathrm{Abc}$ & $4,75 \mathrm{Ac}$ & $2,44 \mathrm{Ac}$ & $12,45 \mathrm{~A}$ \\
\hline 135 & $19,67 \mathrm{ABa}$ & 16,18 ABCab & $15,96 \mathrm{ABab}$ & $9,33 \mathrm{Abc}$ & $3,94 \mathrm{Ac}$ & $2,92 \mathrm{Ac}$ & $11,34 \mathrm{~A}$ \\
\hline 125 & $20,11 \mathrm{ABa}$ & $17,40 \mathrm{ABab}$ & $18,30 \mathrm{Aa}$ & $9,75 \mathrm{Abc}$ & $3,81 \mathrm{Ac}$ & $4,25 \mathrm{Ac}$ & $12,27 \mathrm{~A}$ \\
\hline 805 & $23,19 \mathrm{Aa}$ & $18,05 \mathrm{ABb}$ & $12,02 \mathrm{ABCbc}$ & 6,93 Acd & 6,60 Acd & 3,31 Ad & $11,69 \mathrm{~A}$ \\
\hline 701 & $14,43 \mathrm{Ba}$ & $8,44 \mathrm{Cab}$ & $5,77 \mathrm{Cb}$ & $3,15 \mathrm{Ab}$ & $1,91 \mathrm{Ab}$ & $1,76 \mathrm{Ab}$ & $5,91 \mathrm{~A}$ \\
\hline 425 & $16,55 \mathrm{ABa}$ & $11,31 \mathrm{BCab}$ & 9,44 BCabc & $6,29 \mathrm{Abc}$ & $2,96 \mathrm{Ac}$ & $3,48 \mathrm{Abc}$ & 8,34 \\
\hline Médias & 19,06 a & $15,37 \mathrm{~b}$ & $12,95 \mathrm{~b}$ & $7,28 \mathrm{c}$ & $3,99 \mathrm{~d}$ & $3,03 \mathrm{~d}$ & 30,51 \\
\hline
\end{tabular}

- Médias seguidas por letras iguais, maiúsculas na vertical ou minúsculas na horizontal, não diferem entre si pelo teste de Tukey ao nível de $5 \%$ de probabilidade. 
enquanto o cultivar C701 reduziu a partir de $20 \mathrm{mg} . \mathrm{L}^{-1}$ de alumínio e o cultivar C805 de 10 mg.L $\mathrm{L}^{-1}$ de alumínio na solução.

O comportamento da extração de magnésio pelas raízes em cada cultivar, em função dos níveis de alumínio aplicados, é apresentado na Figura 17, onde são apresentadas as equações de regressão entre a extração de magnésio pelas raízes (mg.planta ${ }^{-1}$ ) e as doses de alumínio (mg.L-1), para os seis cultivares estudados. Assim, todas as regressões representam a redução da extração pelas raízes em função dos níveis de alumínio, porém os cultivares C125, C425, C135 e C525 apresentaram reduções representadas por equações lineares, enquanto os demais cultivares apresentaram reduções representadas por equações quadráticas, com mínimos em 44,9 e 59,9 mg.L ${ }^{-1}$ de alumínio para os cultivares C701 e C805 respectivamente.

Na Tabela 32 observa-se que, na ausência de alumínio, somente o cultivar C701 apresentou extração de magnésio pelas raízes significativamente menor, diferindo entretanto somente do cultivar C805. O nível $20 \mathrm{mg} . \mathrm{L}^{-1}$ foi o que melhor diferenciou os cultivares quanto ao seu comportamento em relação ao alumínio. Assim, nesse nível, os cultivares C525, C135, C125 e C805 apresentaram as maiores extrações de magnésio pelas raízes, diferindo significativamente somente do cultivar $\mathrm{C} 701$.

A Tabela 33 apresenta a extração de magnésio pelos colmos (mg.planta-1) em função dos níveis de alumínio estudados (mg.L ${ }^{-1}$ ), dentro de cada cultivar. Observa-se que os cultivares estudados, embora tenham todos apresentado redução na extração de magnésio pelas folhas com o aumento da concentração de alumínio da solução, apresentaram comportamentos diversos em relação aos níveis de alumínio. Assim, os cultivares C135, C125 e C425 apresentaram redução significativa na extração de magnésio pelos colmos a partir de 30 mg.L-1 de alumínio na solução e os cultivares C525, C805 e C701 praticamente não apresentaram redução significativa na extração pelos colmos com até $10 \mathrm{mg} . \mathrm{L}^{-1}$ de alumínio na solução.

O comportamento da extração de magnésio pelos colmos em cada cultivar, em função dos níveis de alumínio aplicados, é apresentado na Figura 18, onde são apresentadas as equações de regressão entre a extração de magnésio pelos colmos (mg.planta-1) e os níveis de alumínio (mg.L-1), dos seis cultivares estudados. Assim, todas as regressões representam a redução da extração de 


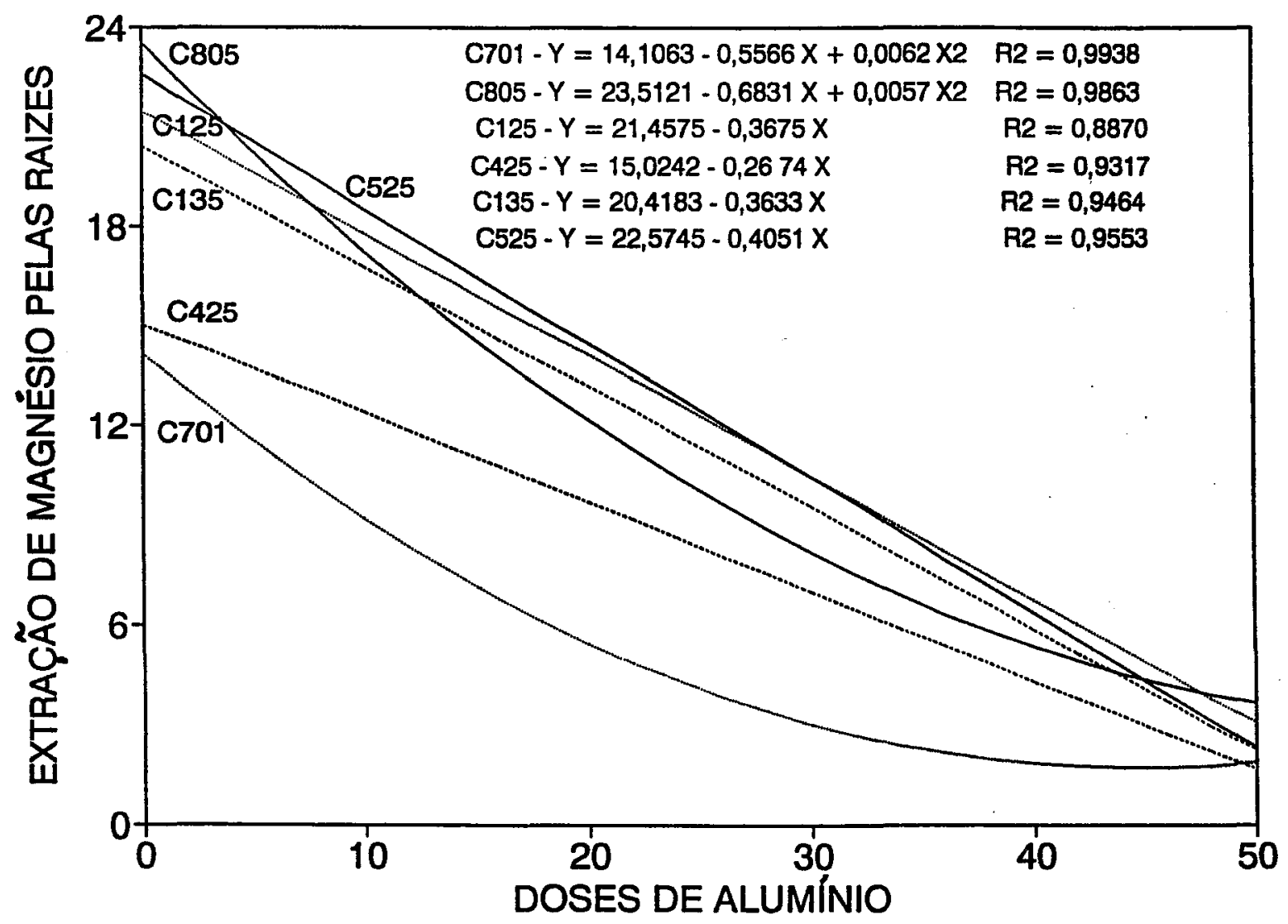

Figura 17. Regressões entre a extração de magnésio pelas raizes (g.planta-1) e os níveis de alumínio (mg.L ${ }^{-1}$ ) para os seis cultivares estudados. 
Tabela 33. Extração de magnésio pelos colmos (mg.planta $\left.{ }^{-1}\right)$ em função dos níveis de alumínio estudados (mg. $\left.\mathrm{L}^{-1}\right)$, dentro de cada cultivar (médias de quatro repetições).

\begin{tabular}{|c|c|c|c|c|c|c|c|}
\hline \multirow[t]{2}{*}{ Cultivares } & \multicolumn{6}{|c|}{ Alumínio (mg. $\mathrm{L}^{-1}$ ) } & \multirow[t]{2}{*}{ Médias } \\
\hline & 0 & 10 & 20 & 30 & 40 & 50 & \\
\hline 525 & $24,78 \mathrm{ABb}$ & $51,71 \mathrm{Aa}$ & $16,28 \mathrm{ABC}$ & 9,98 Acd & $4,30 \mathrm{Ad}$ & 4,35 Ad & $18,57 \mathrm{~A}$ \\
\hline 135 & $26,29 \mathrm{Aa}$ & $26,02 \mathrm{Ba}$ & $20,61 \mathrm{Aa}$ & $8,16 \mathrm{Ab}$ & $4,19 \mathrm{Ab}$ & $3,35 \mathrm{Ab}$ & $14,77 \mathrm{AB}$ \\
\hline 125 & $24,33 \mathrm{ABa}$ & $28,11 \mathrm{Ba}$ & $23,39 \mathrm{Aa}$ & $10,24 \mathrm{Ab}$ & $5,70 \mathrm{Ab}$ & $6,77 \mathrm{Ab}$ & $16,42 \mathrm{~A}$ \\
\hline 805 & $25,99 \mathrm{Aa}$ & $12,10 \mathrm{Cab}$ & $8,11 \mathrm{BCb}$ & $5,56 \mathrm{Ab}$ & $8,21 \mathrm{Ab}$ & $4,88 \mathrm{Ab}$ & $10,81 \mathrm{BC}$ \\
\hline 701 & $17,62 \mathrm{BCa}$ & $10,02 \mathrm{Cab}$ & $6,22 \mathrm{Cb}$ & $3,33 \mathrm{Ab}$ & $1,88 \mathrm{Ab}$ & $2,05 \mathrm{Ab}$ & $6,85 \mathrm{C}$ \\
\hline 425 & $15,03 \mathrm{Ca}$ & 9,31 Cab & 10,05 BCab & $5,27 \mathrm{Ab}$ & 8,85 Aab & $3,88 \mathrm{Ab}$ & $8,73 \mathrm{C}$ \\
\hline Médias & $22,04 \mathrm{a}$ & $22,88 \mathrm{a}$ & $14,11 \mathrm{~b}$ & $7,09 \mathrm{c}$ & $5,52 \mathrm{c}$ & $4,21 \mathrm{c}$ & 12,70 \\
\hline
\end{tabular}

- Médias seguidas por letras iguais, maiúsculas na vertical ou minúsculas na horizontal, não diferem entre si pelo teste de Tukey ao nivel de $5 \%$ de probabilidade. 


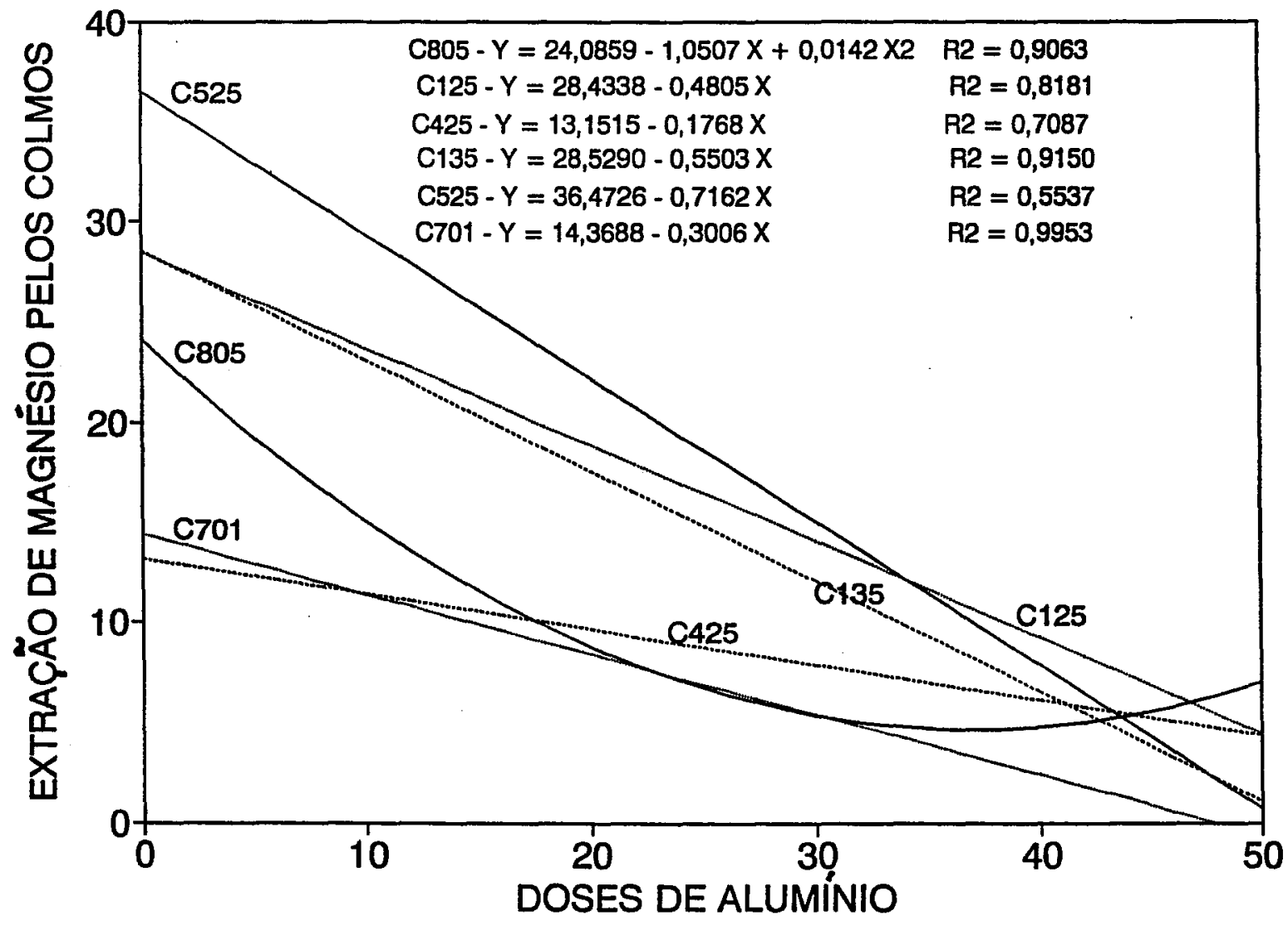

Figura 18. Regressões entre a extração de magnésio pelos colmos(g.planta-1) e os níveis de alumínio (mg.L $\left.{ }^{-1}\right)$ para os seis cultivares estudados. 
magnésio pelos colmos em função dos níveis de alumínio, porém os cultivares $\mathrm{C} 125, \mathrm{C} 425, \mathrm{C} 135, \mathrm{C} 525$ e $\mathrm{C} 701$ apresentaram reduções representadas por equações lineares, enquanto o cultivar C805 apresentou redução representada por uma equação quadrática, com mínimo em $37,0 \mathrm{mg} . \mathrm{L}^{-1}$ de alumínio.

$\mathrm{Na}$ Tabela 33 observa-se que, na ausência de alumínio, os cultivares C135 e C805 apresentaram extrações de magnésio pelos colmos significativamente maiores que os demais, exceto os cultivares C525 e C125. Com o aumento do nível de alumínio da solução, o cultivar C525 apresentou as maiores extrações de magnésio, não diferindo das demais a partir de $40 \mathrm{mg.L} \mathrm{L}^{\mathbf{- 1}}$.

A Tabela 34 apresenta a extração de magnésio (mg.planta-1) das partes amostradas dentro de cada cultivar, para os níveis 0 e $10 \mathrm{mg} . \mathrm{L}^{-1}$ de alumínio na solução. Observa-se que na ausência de alumínio, os cultivares já apresentavam comportamentos diferentes em relação à extração de magnésio pelas três partes amostradas. Assim, os cultivares C525, C135, C125 e C425 apresentavam extrações de magnésio semelhantes para as três partes amostradas, enquanto o cultivar C805 apresentou extração pelas folhas e colmos menores que a das raízes e o cultivar C701 apresentava extração pelos colmos significativamente maior que a das demais partes amostradas. Ainda na ausência de alumínio, quanto à extração de magnésio pelas folhas, o cultivar C135 apresentou valores significativamente maiores que os demais cultivares, exceto os cultivares C525, C125 e C805 dos quais não diferiu; quanto à extração de magnésio pelas raizes, o cultivar C805 diferiu dos demais, exceto os cultivares C525, C135 e C125; quanto à extração de magnésio pelos colmos, o cultivar C805 diferiu dos demais cultivares, exceto os cultivares C525, C135 e C125 dos quais não diferiram estatisticamente.

No nível 10 mg.L $\mathbf{~}^{-1}$ de alumínio, observa-se que os cultivares também apresentavam comportamentos diversos em relação à extração de magnésio pelas três partes amostradas. Assim, os cultivares C805, C701 e C425 apresentavam as três partes amostradas com extrações estatisticamente semelhantes, enquanto o cultivar C525 apresentava extrações de magnésio pelas raízes e pelos colmos superior à das folhas, o cultivar C125 apresentou extração de magnésio pelos colmos maior que as extrações pelas folhas e pelas raízes. Ainda no nível $10 \mathrm{mg} . \mathrm{L}^{-1}$ de alumínio, quanto à extração de magnésio pelas folhas, o cultivar C525 apresentou valores significativamente maiores que os 
Tabela 34: Extração de magnésio (mg.planta ${ }^{-1}$ ) em função das partes amostradas, dentro de cada cultivar, para os níveis 0 e $10 \mathrm{mg} \cdot \mathrm{L}^{-1}$ de alumínio (médias de quatro repetições).

\begin{tabular}{||c|c|c|c|c||}
\hline \multirow{2}{*}{ Cultivares } & \multicolumn{5}{|c|}{ Nivel 0 de Alumínio } \\
\cline { 2 - 5 } & Folhas & Raízes & Colmos & Médias \\
\hline 525 & $19,72 \mathrm{ABa}$ & $20,39 \mathrm{ABa}$ & $24,79 \mathrm{ABa}$ & $21,63 \mathrm{AB}$ \\
\hline 135 & $23,71 \mathrm{Aa}$ & $19,68 \mathrm{ABa}$ & $26,29 \mathrm{Aa}$ & $23,23 \mathrm{~A}$ \\
\hline 125 & $17,21 \mathrm{ABa}$ & $20,11 \mathrm{ABa}$ & $24,33 \mathrm{ABa}$ & $20,55 \mathrm{AB}$ \\
\hline 805 & $16,86 \mathrm{ABb}$ & $23,19 \mathrm{Aa}$ & $25,99 \mathrm{Aa}$ & $22,01 \mathrm{~A}$ \\
\hline 701 & $13,12 \mathrm{Bb}$ & $14,44 \mathrm{Bb}$ & $17,62 \mathrm{BCa}$ & $15,06 \mathrm{C}$ \\
\hline 425 & $14,92 \mathrm{Ba}$ & $16,55 \mathrm{ABa}$ & $15,02 \mathrm{Ca}$ & $15,50 \mathrm{BC}$ \\
\hline Médias & $17,59 \mathrm{~b}$ & $19,06 \mathrm{a}$ & $22,34 \mathrm{a}$ & 19,66 \\
\hline & & Nível $10 \mathrm{de} \mathrm{Alumíni}$ & & \\
\hline 525 & $34,96 \mathrm{Ab}$ & $20,25 \mathrm{Aa}$ & $51,71 \mathrm{Aa}$ & $35,64 \mathrm{~A}$ \\
\hline 135 & $20,75 \mathrm{Bab}$ & $16,19 \mathrm{ABb}$ & $26,02 \mathrm{Ba}$ & $20,99 \mathrm{~B}$ \\
\hline 125 & $18,80 \mathrm{Bb}$ & $17,41 \mathrm{ABb}$ & $28,11 \mathrm{Ba}$ & $21,43 \mathrm{~B}$ \\
\hline 805 & $10,56 \mathrm{Ca}$ & $18,05 \mathrm{ABa}$ & $12,10 \mathrm{Ca}$ & $13,57 \mathrm{BC}$ \\
\hline 701 & $10,96 \mathrm{Ca}$ & $8,45 \mathrm{Ca}$ & $10,02 \mathrm{Ca}$ & $9,81 \mathrm{C}$ \\
\hline 425 & $10,53 \mathrm{Ca}$ & $11,32 \mathrm{BCa}$ & $9,31 \mathrm{Ca}$ & $10,39 \mathrm{C}$ \\
\hline Médias & $17,76 \mathrm{a}$ & $22,88 \mathrm{a}$ & $15,27 \mathrm{~b}$ & 18,34 \\
\hline \hline
\end{tabular}

- Médias seguidas por letras iguais, maiúsculas na vertical ou minúsculas na horizontal, dentro de cada nível de alumínio, não diferem entre si pelo teste de Tukey ao nível de $5 \%$ de probabilidade 
demais cultivares; quanto à extração pelas raízes, o cultivar C525 diferiu dos demais cultivares, exceto $\mathrm{C} 135, \mathrm{C} 125$ e C805; quanto à extração de magnésio pelos colmos, o cultivar C525 diferiu dos demais cultivares.

A Tabela 35 apresenta a extração de magnésio (mg.planta-1) das partes amostradas dentro de cada cultivar, para os níveis 20 e $30 \mathrm{mg} . \mathrm{L}^{-1}$ de alumínio na solução. Observa-se que no nível $20 \mathrm{mg} . \mathrm{L}^{-1}$ de alumínio, os cultivares apresentaram extrações de magnésio que não diferiram significativamente nas três partes amostradas. Ainda no nível $20 \mathrm{mg} . \mathrm{L}^{-1}$ de alumínio, quanto à extração de magnésio pelas folhas, o cultivar $\mathrm{C} 125$ diferiu dos demais, exceto dos cultivares C525 e C135; quanto à extração de magnésio pelas raízes, o cultivar $\mathrm{C} 125$ diferiu dos demais cultivares, exceto dos cultivares $\mathrm{C} 525$, C135 e C805; quanto à extração de magnésio pelos colmos, os cultivares C135 e C125 diferiram dos demais, exceto do cultivar C525.

No nível 30 mg.L ${ }^{-1}$ de alumínio, observa-se que os cultivares não apresentaram diferenças de comportamento quanto à extração de magnésio pelas três partes amostradas dentro de cada cultivar nem quanto aos cultivares dentro das partes amostradas.

A Tabela 36 apresenta a extração de magnésio (mg.planta-1) das partes amostradas dentro de cada cultivar, para os níveis 40 e $50 \mathrm{mg} . \mathrm{L}^{-1}$ de alumínio na solução. Observa-se que nos níveis 40 e $50 \mathrm{mg} . \mathrm{L}^{-1}$ de alumínio, os cultivares não apresentaram diferenças de comportamento quanto à extração de magnésio pelas três partes amostradas dentro de cada cultivar nem quanto aos cultivares dentro das partes amostradas

\subsection{Extração de alumínio}

A Tabela 37 apresenta a extração de alumínio pelas folhas $\left(\mu \mathrm{g}_{\text {planta }} \mathbf{- 1}\right)$ em função dos níveis de alumínio estudados (mg.L $\mathrm{L}^{\mathbf{1}}$ ), dentro de cada cultivar. Observa-se que os cultivares, não apresentaram diferenças na extração de alumínio pelas folhas com o aumento da concentração de alumínio da solução, independente do nível de alumínio presente e dos cultivares, mostrando que o alumínio absorvido pelas raízes não foi translocado para as folhas.

O comportamento da extração de alumínio pelas folhas em cada cultivar, em função dos níveis de alumínio aplicados, é apresentado na Figura 19, 
Tabela 35: Extração de magnésio (mg.planta ${ }^{-1}$ ) em função das partes amostradas, dentro de cada cultivar, para os níveis 20 e $30 \mathrm{mg} . \mathrm{L}^{-1}$ de alummínio (médias de quatro repetições).

\begin{tabular}{|c|c|c|c|c||}
\hline \multirow{2}{*}{ Cultivares } & \multicolumn{5}{|c|}{ Nível 20 de Alumínio } \\
\cline { 2 - 5 } & Folhas & Raizes & Colmos & Médias \\
\hline 525 & $18,51 \mathrm{ABa}$ & $16,21 \mathrm{ABa}$ & $16,28 \mathrm{ABa}$ & $16,99 \mathrm{~A}$ \\
\hline 135 & $18,65 \mathrm{ABa}$ & $15,97 \mathrm{ABa}$ & $20,61 \mathrm{Aa}$ & $18,41 \mathrm{~A}$ \\
\hline 125 & $22,20 \mathrm{Aa}$ & $18,30 \mathrm{Aa}$ & $23,39 \mathrm{Aa}$ & $21,30 \mathrm{~A}$ \\
\hline 805 & $10,45 \mathrm{BCa}$ & $12,02 \mathrm{ABCa}$ & $8,11 \mathrm{BCa}$ & $10,19 \mathrm{~B}$ \\
\hline 701 & $6,98 \mathrm{Ca}$ & $5,77 \mathrm{Ca}$ & $6,23 \mathrm{Ca}$ & $6,32 \mathrm{~B}$ \\
\hline 425 & $7,25 \mathrm{Ca}$ & $9,44 \mathrm{BCa}$ & $10,05 \mathrm{BCa}$ & $8,91 \mathrm{~B}$ \\
\hline Médias & $14,00 \mathrm{a}$ & $12,95 \mathrm{a}$ & $14,11 \mathrm{a}$ & 13,69 \\
\hline & & Nível $30 \mathrm{de} \mathrm{Alumínio}$ & \\
\hline 525 & $12,77 \mathrm{Aa}$ & $10,64 \mathrm{Aa}$ & $9,99 \mathrm{Aa}$ & $11,13 \mathrm{~A}$ \\
\hline 135 & $8,50 \mathrm{Aa}$ & $9,34 \mathrm{Aa}$ & $8,16 \mathrm{Aa}$ & $8,67 \mathrm{BC}$ \\
\hline 125 & $11,53 \mathrm{Aa}$ & $9,75 \mathrm{Aa}$ & $10,24 \mathrm{Aa}$ & $10,51 \mathrm{~A}$ \\
\hline 805 & $7,21 \mathrm{Aa}$ & $6,93 \mathrm{Aa}$ & $5,56 \mathrm{Aa}$ & $6,57 \mathrm{C}$ \\
\hline 701 & $4,73 \mathrm{Aa}$ & $3,15 \mathrm{Aa}$ & $3,33 \mathrm{Aa}$ & $3,73 \mathrm{D}$ \\
\hline 425 & $6,55 \mathrm{Aa}$ & $6,29 \mathrm{Aa}$ & $5,27 \mathrm{Aa}$ & $6,03 \mathrm{CD}$ \\
\hline Médias & $8,55 \mathrm{a}$ & $7,09 \mathrm{a}$ & $7,68 \mathrm{a}$ & 7,77 \\
\hline \hline
\end{tabular}

- Médias seguidas por letras iguais, maiúsculas na vertical ou minúsculas na horizontal, dentro de cada nível de alumínio, não diferem entre si pelo teste de Tukey ao nível de $5 \%$ de probabilidade 
Tabela 36: Extração de magnésio (mg.planta ${ }^{-1}$ ) em função das partes amostradas, dentro de cada cultivar, para os níveis 40 e $50 \mathrm{mg} \cdot \mathrm{L}^{-1}$ de alumínio (médias de quatro repetições).

\begin{tabular}{|c|c|c|c|c||}
\hline \multirow{2}{*}{ Cultivares } & \multicolumn{5}{|c|}{ Nivel 40 de Alumínio } \\
\cline { 2 - 5 } & Folhas & Raízes & Colmos & Médias \\
\hline 525 & $9,38 \mathrm{Aa}$ & $4,75 \mathrm{Aa}$ & $4,30 \mathrm{Aa}$ & $6,14 \mathrm{AB}$ \\
\hline 135 & $6,56 \mathrm{Aa}$ & $3,94 \mathrm{Aa}$ & $4,19 \mathrm{Aa}$ & $4,89 \mathrm{~B}$ \\
\hline 125 & $8,27 \mathrm{Aa}$ & $3,81 \mathrm{Aa}$ & $5,70 \mathrm{Aa}$ & $5,93 \mathrm{AB}$ \\
\hline 805 & $6,82 \mathrm{Aa}$ & $6,60 \mathrm{Aa}$ & $8,21 \mathrm{Aa}$ & $7,21 \mathrm{~A}$ \\
\hline 701 & $2,87 \mathrm{Aa}$ & $1,91 \mathrm{Aa}$ & $1,88 \mathrm{Aa}$ & $2,22 \mathrm{C}$ \\
\hline 425 & $4,57 \mathrm{Aa}$ & $2,96 \mathrm{Aa}$ & $8,85 \mathrm{Aa}$ & $5,46 \mathrm{~B}$ \\
\hline Médias & $6,41 \mathrm{a}$ & $3,40 \mathrm{~b}$ & $5,52 \mathrm{ab}$ & 5,31 \\
\hline & & Nivel $50 \mathrm{de} \mathrm{Aluminio}$ & \\
\hline 525 & $6,86 \mathrm{Aa}$ & $2,44 \mathrm{Aa}$ & $4,35 \mathrm{Aa}$ & $4,55 \mathrm{~B}$ \\
\hline 135 & $5,55 \mathrm{Aa}$ & $2,92 \mathrm{Aa}$ & $3,35 \mathrm{Aa}$ & $3,94 \mathrm{BC}$ \\
\hline 125 & $7,94 \mathrm{Aa}$ & $4,25 \mathrm{Aa}$ & $6,77 \mathrm{Aa}$ & $6,32 \mathrm{~A}$ \\
\hline 805 & $5,43 \mathrm{Aa}$ & $3,31 \mathrm{Aa}$ & $4,88 \mathrm{Aa}$ & $4,54 \mathrm{~B}$ \\
\hline 701 & $4,81 \mathrm{Aa}$ & $1,76 \mathrm{Aa}$ & $2,05 \mathrm{Aa}$ & $2,87 \mathrm{C}$ \\
\hline 425 & $5,47 \mathrm{Aa}$ & $3,48 \mathrm{Aa}$ & $3,88 \mathrm{Aa}$ & $4,28 \mathrm{~B}$ \\
\hline Médias & $6,01 \mathrm{a}$ & $3,03 \mathrm{c}$ & $4,21 \mathrm{~b}$ & 4,41 \\
\hline \hline
\end{tabular}

- Médias seguidas por letras iguais, maiúsculas na vertical ou minúsculas na horizontal, dentro de cada nível de alumínio, não diferem entre si pelo teste de Tukey ao nivel de $5 \%$ de probabilidade 
Tabela 37. Extração de alumínio pelas folhas ( $\mu \mathrm{g}$.planta $\left.{ }^{-1}\right)$ em função dos níveis de alumínio estudados (mg. $\left.\mathrm{L}^{-1}\right)$, dentro de cada cultivar (médias de quatro repetiçōes).

\begin{tabular}{|c|c|c|c|c|c|c|c|}
\hline \multirow[t]{2}{*}{ Cultivares } & \multicolumn{6}{|c|}{ Alumínio (mg. $\left.\mathrm{L}^{-1}\right)$} & \multirow[t]{2}{*}{ Médias } \\
\hline & 0 & 10 & 20 & 30 & 40 & 50 & \\
\hline 525 & $462,92 \mathrm{Aa}$ & $533,87 \mathrm{Aa}$ & $358,77 \mathrm{Aa}$ & $316,47 \mathrm{Aa}$ & $291,27 \mathrm{Aa}$ & $166,35 \mathrm{Aa}$ & $354,95 \mathrm{~B}$ \\
\hline 135 & $769,47 \mathrm{Aa}$ & $546,15 \mathrm{Aa}$ & $411,95 \mathrm{Aa}$ & $226,08 \mathrm{Aa}$ & $241,45 \mathrm{Aa}$ & $219,10 \mathrm{Aa}$ & $402,37 \mathrm{~B}$ \\
\hline 125 & $363,72 \mathrm{Aa}$ & $477,15 \mathrm{Aa}$ & $409,85 \mathrm{Aa}$ & $382,25 \mathrm{Aa}$ & $311,45 \mathrm{Aa}$ & $183,67 \mathrm{Aa}$ & $354,68 \mathrm{~B}$ \\
\hline 805 & $803,00 \mathrm{Aa}$ & $452,80 \mathrm{Aa}$ & $472,22 \mathrm{Aa}$ & $661,25 \mathrm{Aa}$ & $618,15 \mathrm{Aa}$ & $490,45 \mathrm{Aa}$ & $582,98 \mathrm{~A}$ \\
\hline 701 & $477,55 \mathrm{Aa}$ & $471,37 \mathrm{Aa}$ & $307,92 \mathrm{Aa}$ & $394,77 \mathrm{Aa}$ & $274,07 \mathrm{Aa}$ & $433,75 \mathrm{Aa}$ & $393,24 \mathrm{~B}$ \\
\hline 425 & $567,72 \mathrm{Aa}$ & $365,35 \mathrm{Aa}$ & $579,27 \mathrm{Aa}$ & $662,43 \mathrm{Aa}$ & $312,17 \mathrm{Aa}$ & $891,33 \mathrm{Aa}$ & $563,03 \mathrm{~A}$ \\
\hline Médias & $574,07 \mathrm{a}$ & 474,45 a & $423,33 \mathrm{~b}$ & $440,54 \mathrm{~b}$ & $341,43 \mathrm{~b}$ & 397,42 b & 441,87 \\
\hline
\end{tabular}

- Médias seguidas por letras iguais, maiúsculas na vertical ou minúsculas na horizontal, não diferem entre si pelo teste de Tukey ao nível de $5 \%$ de probabilidade. 


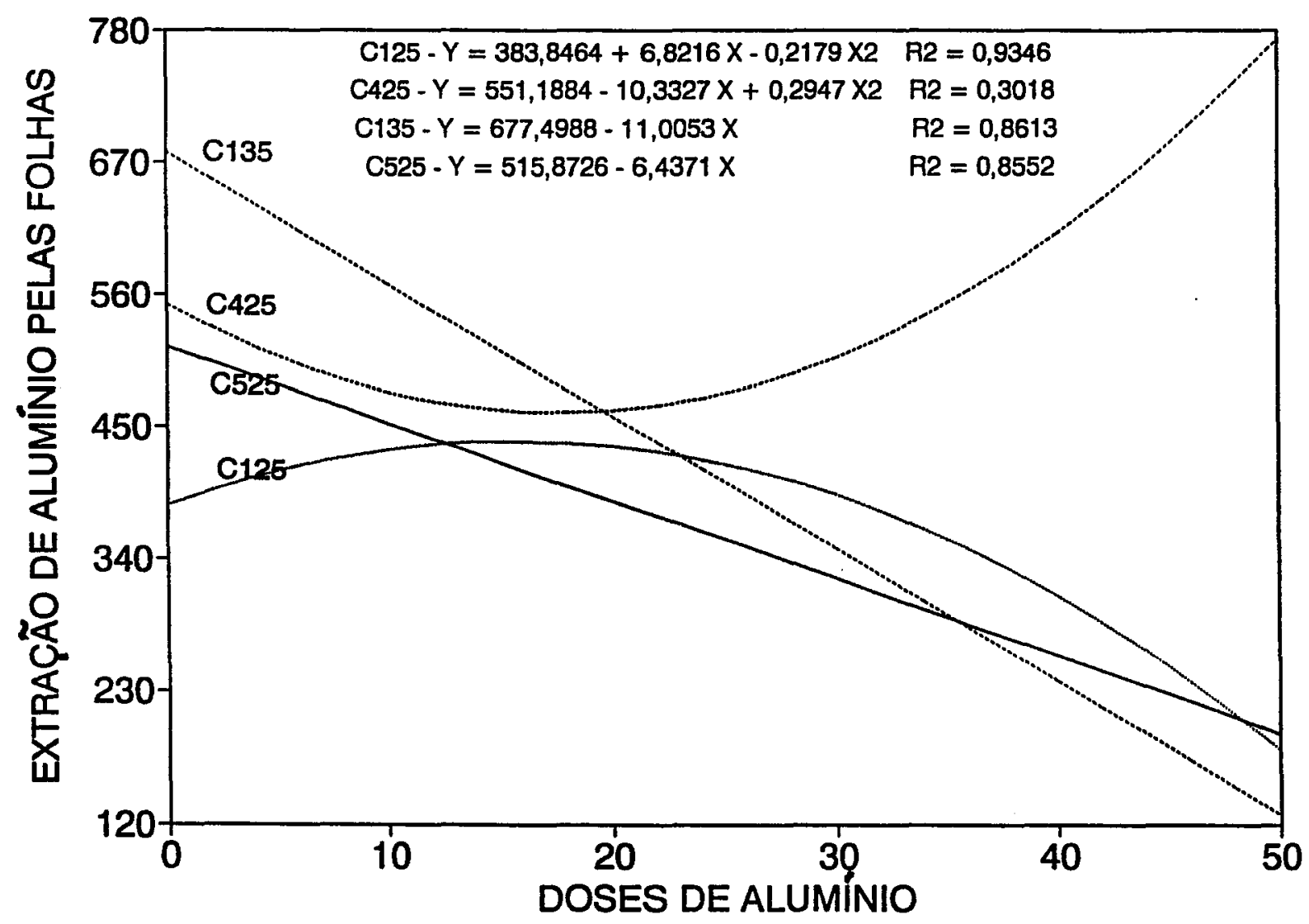

Figura 19. Regressões entre a extração de alumínio pelas folhas (g.planta-1) e os niveis de alumínio (mg.L $\left.{ }^{-1}\right)$ para quatro dos seis cultivares estudados. 
onde são mostradas as equações de regressão entre a extração de alumínio pelas folhas ( $\mu$ g.planta $\left.{ }^{-1}\right)$ e as doses de alumínio (mg.L ${ }^{-1}$ ), para quatro dos seis cultivares estudados. Assim, todas as regressões, exceto a do cultivar $\mathrm{C} 425$ que apresenta coeficiente de determinação bastante baixo, representam a redução da extração de alumínio pelas folhas em função dos níveis de alumínio, porém os cultivares $\mathrm{C} 135$ e C525 apresentaram reduções representadas por equações lineares, enquanto os demais cultivares apresentou comportamento representado por equação quadrática, com mínimo em $17,5 \mathrm{mg} . \mathrm{L}^{-1}$ e máximo em $15,7 \mathrm{mg}$. L1 de alumínio para $\mathrm{C} 425$ e C125, respectivamente.

A Tabela 38 apresenta a extração de alumínio pelas raízes $\left(\mu \mathrm{g}\right.$. planta $\left.^{-1}\right)$ em função dos níveis de alumínio estudados (mg.L-1), dentro de cada cultivar. Observa-se que todos os cultivares estudados apresentaram aumento na extração de alumínio pelas raízes com o aumento da concentração de alumínio da solução, apresentando entretanto comportamentos diferentes em relação aos níveis de alumínio. Assim, os cultivares C125, C805 e C701 apresentaram aumentos significativos na extração de alumínio pelas raízes até $10 \mathrm{mg} . \mathrm{L}^{-1}$ de alumínio na solução, não apresentando diferenças a partir de $20 \mathrm{mg} . \mathrm{L}^{-1}$; os cultivares C135 e C425 apresentaram aumentos significativos na extração de alumínio pelas raízes até $20 \mathrm{mg} . \mathrm{L}^{-1}$, não apresentando diferença significativa nos níveis maiores e o cultivar C525 apresentou aumentos progressivos na extração de alumínio pelas raizes em função dos niveis de alumínio da solução até $30 \mathrm{mg} . \mathrm{L}^{\mathbf{- 1}}$, quando não apresentou mais diferença significativa.

O comportamento da extração de alumínio pelas raizes em cada cultivar, em função dos níveis de alumínio aplicados, é apresentado na Figura 20, onde são representadas as equações de regressão entre a extração de alumínio pelas raízes ( $\mu$ g.planta $\left.{ }^{-1}\right)$ e as doses de alumínio (mg.L-1 $)$, para os seis cultivares estudados. Assim, todas as regressões representam o aumento na extração de alumínio pelas raízes em função dos níveis de alumínio, porém o cultivar C525 apresentou aumentos representados por equações lineares, enquanto os demais cultivares apresentaram aumentos representados por equações quadráticas, com máximos em 28,$2 ; 31,0 ; 34,0 ; 34,9$ e 38,0 mg.L $\mathbf{~}^{-1}$ de alumínio para os cultivares C701, C805, C135, C125 e C425 respectivamente. Observou-se que o sistema radicular do cultivar C805 extraiu mais alumínio que o dos demais cultivares, a partir do nível $10 \mathrm{mg} . \mathrm{L}^{-1}$ de alumínio na solução nutritiva. 
Tabela 38. Extração de alumínio pelas raízes $\left(\mu \mathrm{g} \cdot \mathrm{planta}^{-1}\right)$ em função dos níveis de alumínio estudados $\left(\mathrm{mg} \cdot \mathrm{L}^{-1}\right)$, dentro de cada cultivar (médias de quatro repetições).

\begin{tabular}{|c|c|c|c|c|c|c|c||}
\hline \multirow{2}{*}{ Cultivares } & \multicolumn{7}{|c|}{ Alumínio (mg.L ${ }^{-1}$ ) } \\
\cline { 2 - 8 } & 0 & 10 & 20 & 30 & 40 & 50 \\
\hline 525 & $12714,45 \mathrm{Ac}$ & $9330,65 \mathrm{Bc}$ & $13839,07 \mathrm{Bc}$ & $21651,15 \mathrm{CDb}$ & $27843,87 \mathrm{Ba}$ & $23128,95 \mathrm{Ba}$ & $18084,69 \mathrm{~B}$ \\
\hline 135 & $5879,80 \mathrm{Bc}$ & $9419,47 \mathrm{Bc}$ & $17061,15 \mathrm{Bb}$ & $23766,42 \mathrm{Ca}$ & $25403,87 \mathrm{Ba}$ & $15510,07 \mathrm{Ca}$ & $16173,44 \mathrm{BC}$ \\
\hline 125 & $2545,60 \mathrm{Bc}$ & $10253,50 \mathrm{Bb}$ & $18652,47 \mathrm{Ba}$ & $16547,92 \mathrm{Da}$ & $14890,25 \mathrm{Cab}$ & $17001,87 \mathrm{Ca}$ & $13315,27 \mathrm{C}$ \\
\hline 805 & $1774,40 \mathrm{Bd}$ & $19340,37 \mathrm{Ac}$ & $59409,22 \mathrm{Aa}$ & $58598,42 \mathrm{Aa}$ & $59425,70 \mathrm{Aa}$ & $34216,80 \mathrm{Ab}$ & $38794,15 \mathrm{~A}$ \\
\hline 701 & $4217,75 \mathrm{Bc}$ & $10790,40 \mathrm{Bb}$ & $18631,60 \mathrm{Ba}$ & $18232,60 \mathrm{CDa}$ & $22183,57 \mathrm{Ba}$ & $7343,42 \mathrm{Dbc}$ & $13566,56 \mathrm{C}$ \\
\hline 425 & $1417,53 \mathrm{Bd}$ & $12203,30 \mathrm{Bc}$ & $13716,35 \mathrm{Bc}$ & $41185,32 \mathrm{Ba}$ & $22626,12 \mathrm{Bb}$ & $26713,97 \mathrm{Bb}$ & $19643,77 \mathrm{~B}$ \\
\hline Médias & $4758,25 \mathrm{~d}$ & $11889,62 \mathrm{c}$ & $23551,65 \mathrm{~b}$ & $29996,95 \mathrm{a}$ & $28728,90 \mathrm{a}$ & $20652,52 \mathrm{~b}$ & 19929,65 \\
\hline
\end{tabular}

- Médias seguidas por letras iguais, maiúsculas na vertical ou minúsculas na horizontal, não diferem entre si pelo teste de Tukey ao nível de 5\% de probabilidade. 


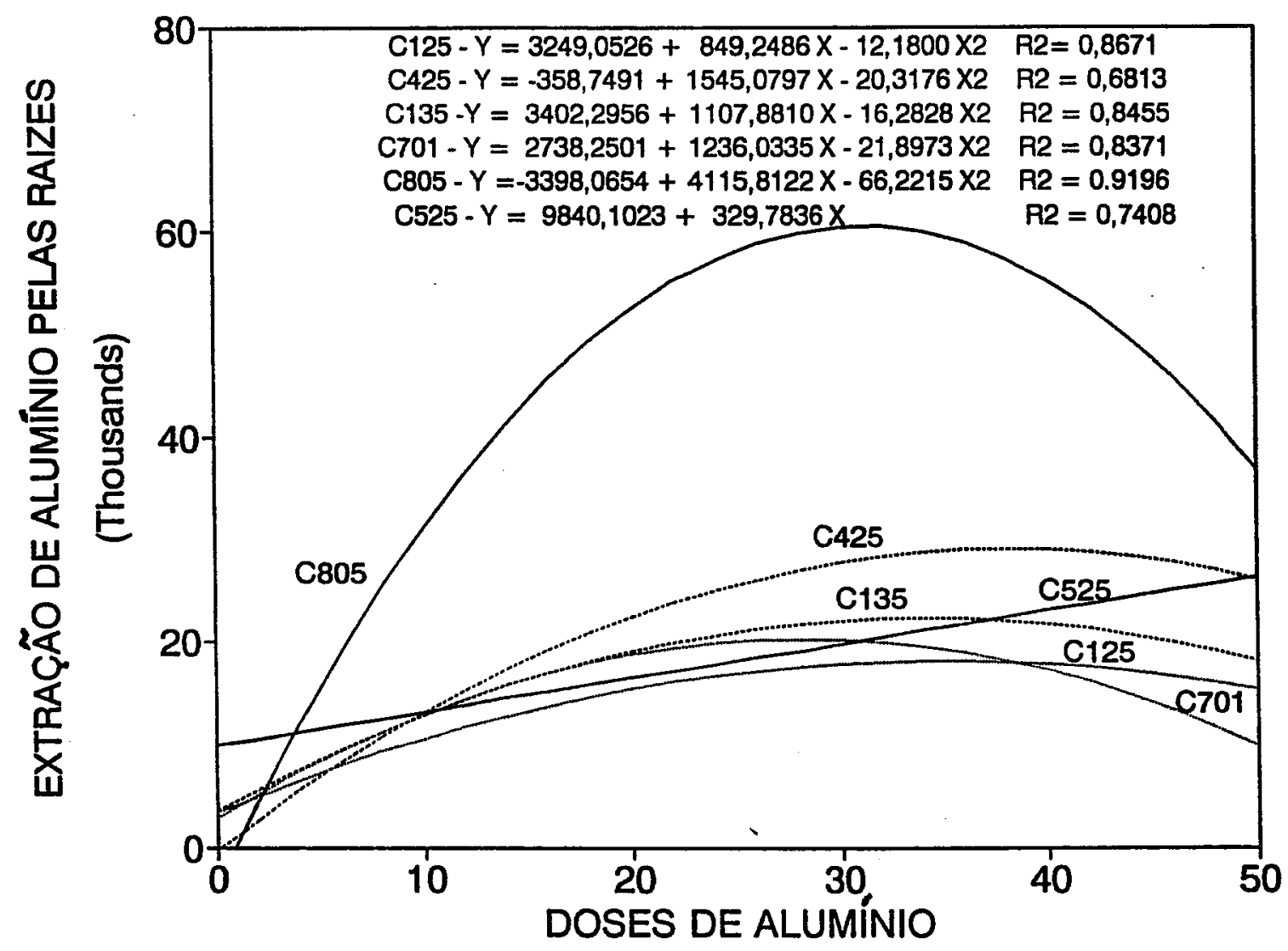

Figura 20. Regressões entre a extração de alumínio pelas raízes (g.planta-1) e os níveis de alumínio (mg.L-1) para os seis cultivares estudados. 
Na Tabela 38 observa-se que, na ausência de alumínio, o cultivar C525 apresentava extração de alumínio pelas raízes significativamente maiores que os demais cultivares, que não diferiram entre si; nos demais níveis foi o cultivar C805 que apresentou as maiores extrações de alumínio. O nível $30 \mathrm{mg}$. $\mathrm{L}^{-1}$ foi o que melhor diferenciou os cultivares quanto ao seu comportamento em relação ao acúmulo de alumínio nas raízes.

A Tabela 39 apresenta a extração de alumínio pelos colmos ( $\mu$ g.planta ${ }^{-1}$ ), em função dos níveis de alumínio estudados $\left(\mathrm{mg}^{-L^{-1}}\right)$, dentro de cada cultivar. Observa-se que os cultivares, não apresentaram diferenças na extração de alumínio pelos colmos com o aumento da concentração de alumínio da solução, independente do nível de alumínio presente e dos cultivares, mostrando que o alumínio absorvido pelas raízes não foi translocado para os colmos.

O comportamento da extração de alumínio pelos colmos em cada cultivar, em função dos níveis de alumínio aplicados, é apresentado na Figura 21, onde são representadas as equações de regressão entre a extração de alumínio pelos colmos ( $\mu$ g.planta ${ }^{-1}$ ) e os níveis de alumínio (mg.L-1), para os seis cultivares estudados. Assim, todas as regressões representam a redução da extração de alumínio pelos colmos, exceto para o cultivar $\mathrm{C} 125$, em função dos níveis de alumínio, porém os cultivares C135, C525, C701 e C805 apresentaram reduções representadas por equações lineares, enquanto os cultivares C125 e C425 apresentaram comportamentos representados por equações quadráticas, com mínimos em 0,9 e 29,8 mg.L-1 de alumínio na solução, respectivamente.

A Tabela 40 apresenta a extração de alumínio $\left(\mu \mathrm{g} \cdot\right.$ planta $\left.^{-1}\right)$ das partes amostradas dentro de cada cultivar, para os níveis 0 e $10 \mathrm{mg} . \mathrm{L}^{-1}$ de alumínio na solução. Observa-se que na ausência de alumínio, os cultivares já apresentavam comportamentos diferentes em relação à extração de alumínio pelas três partes amostradas. Assim, o cultivar C535 apresentava extração de alumínio pelas raizes estatisticamente maior que as outras duas partes, enquanto os demais cultivares não apresentavam diferenças na extração de alumínio pelas três partes amostradas. Ainda na ausência de alumínio, quanto à extração de alumínio pelas folhas e pelos colmos, os cultivares não diferiram entre si; quanto à extração de alumínio pelas raízes, o cultivar C525 diferiu dos demais, que não diferiram entre si. 


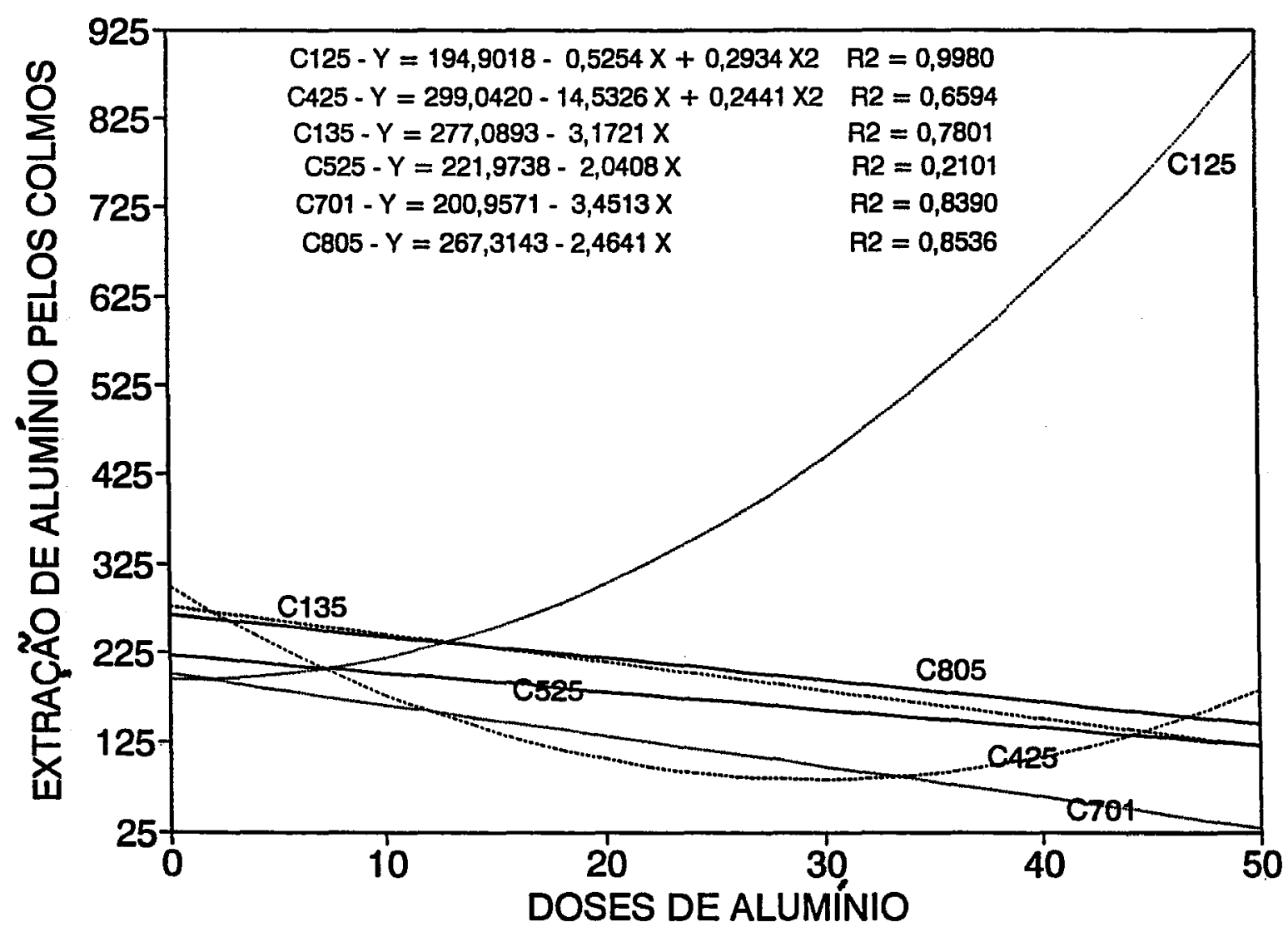

Figura 21. Regressões entre a extração de alumínio pelos colmos (g.planta-1) e os níveis de alumínio (mg. $\mathrm{L}^{-1}$ ) para os seis cultivares estudados. 
Tabela 40: Extração de alumínio ( $\mu$ g.planta ${ }^{-1}$ ) em função das partes amostradas, dentro de cada cultivar, para os níveis 0 e $10 \mathrm{mg} \cdot \mathrm{L}^{-1}$ de alumínio (médias de quatro repetições).

\begin{tabular}{|c|c|c|c|c||}
\hline \multirow{2}{*}{ Cultivares } & \multicolumn{5}{|c|}{ Nível 0 de Alumínio } \\
\cline { 2 - 5 } & Folhas & Raízes & Colmos & Médias \\
\hline 525 & $462,92 \mathrm{Ab}$ & $12714,45 \mathrm{Aa}$ & $218,85 \mathrm{Ab}$ & $4465,41 \mathrm{~A}$ \\
\hline 135 & $769,47 \mathrm{Aa}$ & $5879,80 \mathrm{Ba}$ & $281,27 \mathrm{Aa}$ & $2310,18 \mathrm{~B}$ \\
\hline 125 & $363,72 \mathrm{Aa}$ & $2545,60 \mathrm{Ba}$ & $198,05 \mathrm{Aa}$ & $1035,79 \mathrm{C}$ \\
\hline 805 & $803,00 \mathrm{Aa}$ & $1774,40 \mathrm{Ba}$ & $302,15 \mathrm{Aa}$ & $959,85 \mathrm{C}$ \\
\hline 701 & $477,55 \mathrm{Aa}$ & $4217,75 \mathrm{Ba}$ & $199,52 \mathrm{Aa}$ & $1631,61 \mathrm{BC}$ \\
\hline 425 & $567,72 \mathrm{Aa}$ & $1417,53 \mathrm{Ba}$ & $345,77 \mathrm{Aa}$ & $777,01 \mathrm{C}$ \\
\hline Médias & $574,07 \mathrm{a}$ & $4758,25 \mathrm{a}$ & $257,60 \mathrm{a}$ & 1863,31 \\
\hline & \multicolumn{5}{|c|}{ Nível $10 \mathrm{de} \mathrm{Aluminio}$} \\
\hline 525 & $533,87 \mathrm{Ab}$ & $9330,65 \mathrm{Ba}$ & $304,97 \mathrm{Ab}$ & $3389,83 \mathrm{~B}$ \\
\hline 135 & $546,15 \mathrm{Ab}$ & $9419,47 \mathrm{Ba}$ & $239,40 \mathrm{Ab}$ & $3401,67 \mathrm{~B}$ \\
\hline 125 & $477,15 \mathrm{Ab}$ & $10253,50 \mathrm{Ba}$ & $222,05 \mathrm{Ab}$ & $3650,90 \mathrm{~B}$ \\
\hline 805 & $452,80 \mathrm{Ab}$ & $19340,37 \mathrm{Aa}$ & $218,47 \mathrm{Ab}$ & $6670,59 \mathrm{~A}$ \\
\hline 701 & $471,35 \mathrm{Ab}$ & $10790,40 \mathrm{Ba}$ & $204,50 \mathrm{Ab}$ & $3822,09 \mathrm{~B}$ \\
\hline 425 & $365,35 \mathrm{Ab}$ & $12203,30 \mathrm{Ba}$ & $115,57 \mathrm{Ab}$ & $4228,07 \mathrm{~B}$ \\
\hline Médias & $474,45 \mathrm{~b}$ & $11889,62 \mathrm{a}$ & $217,50 \mathrm{~b}$ & 4193,85 \\
\hline \hline
\end{tabular}

- Médias seguidas por letras iguais, maiúsculas na vertical ou minúsculas na horizontal, dentro de cada nível de alumínio, não diferem entre si pelo teste de Tukey ao nível de $5 \%$ de probabilidade 
No nível $10 \mathrm{mg} . \mathrm{L}^{-1}$ de alumínio, observa-se que os cultivares não apresentaram comportamentos diversos em relação à extração de alumínio pelas três partes amostradas, uma vez que em todos os cultivares, a extração pelas raízes foi estatisticamente maior que pelas folhas e pelos colmos. Ainda no nível 10 mg.L-1 de alumínio, quanto à extração de alumínio pelas folhas e pelos colmos, os cultivares não diferiram entre si, mas quanto à extração pelas raízes, o cultivar C805 diferiu dos demais cultivares.

A Tabela 41 apresenta a extração de alumínio $\left(\mu \mathrm{g} \cdot\right.$ planta $\left.^{-1}\right)$ das partes amostradas dentro de cada cultivar, para os níveis 20 e $30 \mathrm{mg} . \mathrm{L}^{-1}$ de alumínio na solução. Observa-se no nível $20 \mathrm{mg} . \mathrm{L}^{-1}$ de alumínio, o mesmo comportamento do nível $10 \mathrm{mg} . \mathrm{L}^{-1}$. No nível $30 \mathrm{mg} . \mathrm{L}^{-1}$ de alumínio, observa-se que os cultivares apresentaram o mesmo comportamento do nível $20 \mathrm{mg} . \mathrm{L}^{\mathbf{- 1}}$ quanto às partes dentro dos cultivares, diferindo somente no comportamento das raízes dentro dos cultivares, onde o cultivar C805 extraiu mais alumínio, seguido do cultivar $\mathrm{C} 425$, estatisticamente diferentes dos demais cultivares, que não diferiram entre si.

A Tabela 42 apresenta a extração de alumínio ( $\mu$ g.planta-1) das partes amostradas dentro de cada cultivar, para os níveis 40 e $50 \mathrm{mg} . \mathrm{L}^{-1}$ de alumínio na solução. Observa-se no nível $40 \mathrm{mg} . \mathrm{L}^{-1}$ de alumínio, comportamento diferente dos níveis anteriores somente para as raízes dentro dos cultivares, onde o cultivar C805 extraiu mais alumínio, seguido pelos demais cultivares, que diferiram estatisticamente do cultivar $\mathrm{C} 125$. Da mesma forma, para as raízes dentro dos cultivares, no nível $50 \mathrm{mg} . \mathrm{L}^{\mathbf{- 1}}$ de alumínio, os cultivares foram divididos em quatro grupos, C805 extraiu mais alumínio, seguido por C525 e C425; que diferiram de $\mathrm{C} 135$ e $\mathrm{C} 125$ e a menor extração de alumínio foi do cultivar C701.

\subsection{Aspecto das plantas e das raízes}

Observou-se que os cultivares apresentaram um excelente desenvolvimento no nível $0 \mathrm{mg} . \mathrm{L}^{-1}$ de $\mathrm{Al}$. A parte aérea atingiu a altura média de $59,57 \mathrm{~cm}$, sendo bastante vigorosa e as raízes, tanto as adventícias como as fasciculadas, também apresentavam-se vigorosas, sadias e com coloração clara, apresentando um comprimento médio de $46,78 \mathrm{~cm}$. 
Tabela 41: Extração de alumínio ( $\mu$ g.planta ${ }^{-1}$ ) em função das partes amostradas, dentro de cada cultivar, para os níveis 20 e $30 \mathrm{mg} . \mathrm{L}^{-1}$ de alumínio (médias de quatro repetições).

\begin{tabular}{||c|c|c|c|c||}
\hline \multirow{2}{*}{ Cultivares } & \multicolumn{5}{|c|}{ Nível 20 de Alumínio } \\
\cline { 2 - 5 } & Folhas & Raízes & Colmos & Médias \\
\hline 525 & $358,77 \mathrm{Ab}$ & $13839,07 \mathrm{Ba}$ & $91,82 \mathrm{Ab}$ & $4763,22 \mathrm{~B}$ \\
\hline 135 & $411,95 \mathrm{Ab}$ & $17061,15 \mathrm{Ba}$ & $252,55 \mathrm{Ab}$ & $5908,55 \mathrm{~B}$ \\
\hline 125 & $409,85 \mathrm{Ab}$ & $18652,47 \mathrm{Ba}$ & $283,42 \mathrm{Ab}$ & $6448,58 \mathrm{~B}$ \\
\hline 805 & $472,22 \mathrm{Ab}$ & $59409,22 \mathrm{Aa}$ & $198,07 \mathrm{Ab}$ & $20026,51 \mathrm{~A}$ \\
\hline 701 & $307,93 \mathrm{Ab}$ & $18631,60 \mathrm{Ba}$ & $102,20 \mathrm{Ab}$ & $6347,24 \mathrm{~B}$ \\
\hline 425 & $579,27 \mathrm{Ab}$ & $13716,35 \mathrm{Ba}$ & $59,60 \mathrm{Ab}$ & $4785,07 \mathrm{~B}$ \\
\hline Médias & $423,33 \mathrm{~b}$ & $23551,65 \mathrm{a}$ & $164,61 \mathrm{~b}$ & 8046,53 \\
\hline & \multicolumn{5}{|c||}{ Nivel $30 \mathrm{de} \mathrm{Alumíni}$} \\
\hline 525 & $316,47 \mathrm{Ab}$ & $21651,15 \mathrm{Ca}$ & $81,32 \mathrm{Ab}$ & $7349,65 \mathrm{C}$ \\
\hline 135 & $226,07 \mathrm{Ab}$ & $23766,25 \mathrm{Ca}$ & $131,50 \mathrm{Ab}$ & $8041,27 \mathrm{C}$ \\
\hline 125 & $382,25 \mathrm{Ab}$ & $16547,92 \mathrm{Ca}$ & $448,53 \mathrm{Ab}$ & $5992,87 \mathrm{C}$ \\
\hline 805 & $661,25 \mathrm{Ab}$ & $58598,42 \mathrm{Aa}$ & $179,95 \mathrm{Ab}$ & $18813,21 \mathrm{~A}$ \\
\hline 701 & $394,77 \mathrm{Ab}$ & $18232,60 \mathrm{Ca}$ & $79,30 \mathrm{Ab}$ & $6235,56 \mathrm{C}$ \\
\hline 425 & $662,43 \mathrm{Ab}$ & $41185,33 \mathrm{Ba}$ & $130,00 \mathrm{Ab}$ & $13992,58 \mathrm{~B}$ \\
\hline Médias & $440,54 \mathrm{~b}$ & $29996,95 \mathrm{a}$ & 175,08 & 10204,19 \\
\hline \hline
\end{tabular}

- Médias seguidas por letras iguais, maiúsculas na vertical ou minúsculas na horizontal, dentro de cada nível de alumínio, não diferem entre si pelo teste de Tukey ao nível de $5 \%$ de probabilidade 
Tabela 42: Extração de alumínio ( $\mu$ g.planta ${ }^{-1}$ ) em função das partes amostradas, dentro de cada cultivar, para os níveis 40 e $50 \mathrm{mg} . \mathrm{L}^{-1}$ de alumínio (médias de quatro repetições).

\begin{tabular}{|c|c|c|c|c||}
\hline \multirow{2}{*}{ Cultivares } & \multicolumn{5}{|c|}{ Nível 40 de Alumínio } \\
\cline { 2 - 5 } & Folhas & Raízes & Colmos & Médias \\
\hline 525 & $291,27 \mathrm{Ab}$ & $27843,87 \mathrm{Ba}$ & $169,17 \mathrm{Ab}$ & $9434,77 \mathrm{~B}$ \\
\hline 135 & $241,45 \mathrm{Ab}$ & $25403,87 \mathrm{Ba}$ & $137,30 \mathrm{Ab}$ & $8594,21 \mathrm{~B}$ \\
\hline 125 & $311,45 \mathrm{Ab}$ & $14890,25 \mathrm{Ca}$ & $660,05 \mathrm{Ab}$ & $5287,25 \mathrm{~B}$ \\
\hline 805 & $618,15 \mathrm{Ab}$ & $59425,70 \mathrm{Aa}$ & $178,13 \mathrm{Ab}$ & $20073,99 \mathrm{~A}$ \\
\hline 701 & $274,07 \mathrm{Ab}$ & $22183,57 \mathrm{Ba}$ & $43,27 \mathrm{Ab}$ & $7500,31 \mathrm{~B}$ \\
\hline 425 & $312,17 \mathrm{Ab}$ & $22626,12 \mathrm{Ba}$ & $169,60 \mathrm{Ab}$ & $7702,63 \mathrm{~B}$ \\
\hline Médias & $341,43 \mathrm{~b}$ & $28728,90 \mathrm{a}$ & $226,25 \mathrm{~b}$ & 9765,53 \\
\hline & & Nível $50 \mathrm{de} \mathrm{Alumi} n i o$ & \\
\hline 525 & $166,35 \mathrm{Ab}$ & $23128,95 \mathrm{Ba}$ & $159,57 \mathrm{Ab}$ & $7818,29 \mathrm{BC}$ \\
\hline 135 & $219,10 \mathrm{Ab}$ & $15510,07 \mathrm{Ca}$ & $144,70 \mathrm{Ab}$ & $5291,29 \mathrm{CD}$ \\
\hline 125 & $183,67 \mathrm{Ab}$ & $17001,87 \mathrm{Ca}$ & $892,50 \mathrm{Ab}$ & $6026,02 \mathrm{C}$ \\
\hline 805 & $490,45 \mathrm{Ab}$ & $3421,80 \mathrm{Aa}$ & $175,50 \mathrm{Ab}$ & $11621,58 \mathrm{~A}$ \\
\hline 701 & $433,75 \mathrm{Ab}$ & $7343,42 \mathrm{Da}$ & $59,25 \mathrm{Ab}$ & $2612,14 \mathrm{D}$ \\
\hline 425 & $891,23 \mathrm{Ab}$ & $26713,97 \mathrm{Ba}$ & $136,32 \mathrm{Ab}$ & $9247,17 \mathrm{AB}$ \\
\hline Médias & $397,42 \mathrm{~b}$ & $20652,52 \mathrm{a}$ & $258,31 \mathrm{~b}$ & 7102,75 \\
\hline
\end{tabular}

- Médias seguidas por letras iguais, maiúsculas na vertical ou minúsculas na horizontal, dentro de cada nível de alumínio, não diferem entre si pelo teste de Tukey ao nivel de $5 \%$ de probabilidade 
Já no nível $10 \mathrm{mg} . \mathrm{L}^{-1}$ de $\mathrm{Al}$, notou-se que o alumínio interferiu no desenvolvimento das plantas. A parte aérea apresentou uma redução na altura, com média de $48,43 \mathrm{~cm}$. O sistema radicular também foi reduzido, com média de $38,33 \mathrm{~cm}$ de comprimento, apresentando na maioria dos cultivares, coloração avermelhada, raízes adventícias tortuosas e as fasciculadas em menor quantidade, apresentando um ligeiro engrossamento, com início de necrose e emissão de muitas ramificações.

No nível $20 \mathrm{mg} . \mathrm{L}^{-1}$ de $\mathrm{Al}$, as plantas apresentaram a parte aérea com um comprimento médio de $46,77 \mathrm{~cm}$. As raizes tornaram-se menores ainda, algumas com coloração avermelhada, sendo mais grossas e com ramificações pequenas. Os ápices também apresentavam-se grossos, com enrolamento em forma de anzol, e necrosados, apresentando comprimento médio entre os cultivares de $33,84 \mathrm{~cm}$.

A altura da parte aérea foi ainda maior que o comprimento das

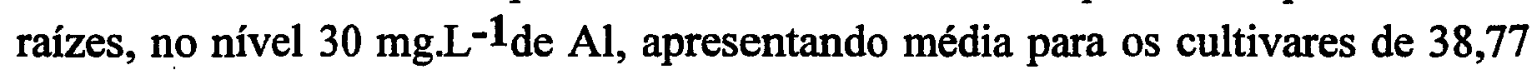
$\mathrm{cm}$, sendo o comprimento médio das raízes de $34,85 \mathrm{~cm}$. As raízes apresentaramse, quando comparadas com o nivel anterior, menos volumosas, mais curtas, com maior engrossamento e com ramificações também mais curtas e grossas e com necrose no ápice.

Observou-se que, a partir do nível $40 \mathrm{mg} \cdot \mathrm{L}^{-1}$ de $\mathrm{Al}$, houve redução drástica da parte aérea, com média de altura para os cultivares de $31,52 \mathrm{~cm}$, sendo o comprimento médio das raízes maior, apresentando uma média de $32,50 \mathrm{~cm}$. Algumas raizes apresentaram coloração avermelhadas, com pouquíssimas ramificações e com engrossamento dos pelos absorventes, sendo porém muito grossas e bastante necrosadas, chegando a desfazer-se, quando tocadas.

No nível $50 \mathrm{mg} . \mathrm{L}^{\mathbf{- 1}} \mathrm{de} \mathrm{Al}$, as plantas apresentaram a parte aérea com altura média de $31,14 \mathrm{~cm}$ e as raízes com média de $33,98 \mathrm{~cm}$. As raízes eram muito grossas, apresentando pontuações necróticas, com pouquíssimas ramificações e engrossamento de pelos absorventes, com características muito semelhantes ao nível de $40 \mathrm{mg} . \mathrm{L}^{-1}$ de Al. 


\subsection{Discussão geral}

De uma forma geral, os cultivares que apresentaram maiores pesos de material seco do sistema radicular foram os que acumularam também maiores pesos de material seco de colmos e folhas, que são os cultivares C805, C525, C125 até $50 \mathrm{mg} . \mathrm{L}^{-1}$ e C135 até $10 \mathrm{mg.L}-1$ de alumínio na solução. Dessa forma, dos cultivares estudados, C701 e C425 foram os que mais sentiram o efeito do alumínio.

O alumínio acumulou-se principalmente no sistema radicular, sendo os cultivares C805 e C425 os que apresentaram maiores acúmulos de alumínio nas raízes, com um transporte desse elemento para a parte aérea das plantas de milho.

A extração de nitrogênio pelas partes amostradas, obedeceu uma distribuição semelhante a dos pesos de material seco. Quanto ao fósforo, somente para os cultivares C525, C125 e C135 foi possível obter curvas de regressão, que representaram reduções nas extrações de fósforo em função do aumento dos níveis de alumínio, mesmo no sistema radicular. Nas raizes o acúmulo de alumínio foi crescente, em função dos níveis de alumínio da solução, demonstrando que esse acúmulo de alumínio nas raízes não é devido somente ao acumulo de fósforo nas mesmas.

Para o potássio, a extração foi maior nos cultivares C525, C125 e C135, que tinham apresentado maior acumulo de massa, o mesmo não acontecendo com o cultivar C805, que embora tenha acumulado bastante massa, não apresentou extração de potássio elevada. A extração de cálcio teve comportamento semelhante à do potássio. A extração de magnésio pelas raízes seguiu a tendência dos pesos de material seco das raízes, enquanto que para a parte aérea o cultivar C805 apresentou comportamento semelhante ao apresentado para o potássio e para o cálcio.

De uma forma geral, pode-se afirmar que dos cultivares estudados, os cultivares $\mathrm{C701}$ e C425 são os mais sensiveis à toxidez causada pelo alumínio, e que os cultivares C525, C125 e C805 são os mais tolerantes, estando o cultivar C135 em uma posição intermediária. 


\section{CONCLUSÕES}

Nas condições do presente trabalho, foi possível chegar-se às seguintes conclusões:

- Os cultivares C525, C125 e C805 são os mais tolerantes à presença do alumínio no meio de cultivo;

- Os cultivares C701 e C425 são os mais sensíveis à presença do alumínio no meio de cultivo;

- O cultivar $\mathrm{C} 135$ apresentou pequena tolerância ao alumínio, até o nível $10 \mathrm{mg} . \mathrm{L}^{-1}$ de aluminio;

- O nível que melhor separou os cultivares tolerantes dos sensíveis foi $20 \mathrm{mg} . \mathrm{L}^{-1}$ de alumínio na solução;

- O acúmulo do alumínio pelo sistema radicular das plantas de milho não é devido somente ao acumulo de fósforo nessa parte. 


\section{REFERÊNCIAS BIBLIOGRÁFICAS}

ADAMS, F. \& LUND, Z.F. Effect of chemical activity of soil solution aluminum on cotton root penetration of acid subsoils. Soil Science, Baltimore, 101:193-8, 1966.

ALAM, S.M. Effect of aluminum on the dry matter and mineral content of rice. Journal of Science and Technology, Peshawar, 7(1/2):1-3, 1983.

ALAM, S.M. \& ADAMS, W.A. Effect of soil pH on the growth and mineral content of oats. Pakistan Journal of Scientific and Industrial Research, Karachi, 22(3):147$51,1979$.

ALVA, A.K.; EDWARDS, D.G.; ASHER, C.F.; BLAMEY, F.P.C. Effects of phosphorus/aluminum molar ratio and calcium concentration on plant response to aluminum toxicity. Soil Science Society of America Journal, Madison, 50:133-7, 1986.

ANDERSON, 1. \& EVANS, H.J. Effect of manganese and certain other metal cations on isocitric dehydrogenase and malic enzyme activities on Phaseolus vulgaris. Plant Physiology, Bethesda, 31:22-8, 1956. 
ANDREW, C.S. \& BERG, P.G. The influence of aluminum on phosphate sorption by whole plant and excised roots of some pasture legumes. Australian Journal of Agricultural Research, East Melbourne, 24:341-51, 1973.

ANDREW, C.S.; JOHNSON, A.D.; SANDLAND, R.L. Effect of aluminum on the growth and chemical composition of some tropical and temperate pasture legumes. Australian Journal of Agricultural Research, East Melbourne, 24:325-39, 1973.

ANGHINONI, I. \& BARBER, S.A. Phosphorus influx and growth characteristics of corn roots as influenced by phosphorus supply. Agronomy Journal, Madison, 72:685-8, 1980.

ARMINGER, W.R.; FOY, C.D.; FLEMING, A.L.; CALDWELL, R.E. Differential tolerance of soybean varieties to an acid soil high in exchangeable aluminum. Agronomy Journal, Madison, 60:67-70, 1968.

AWADA, M.; SUEHISA, R.; KANEHIRO, Y. Effects of lime and phosphorus on yields, growth and petiole composition of papaya. Journal of the American Society for Horticultural Science, Alexandria, 100:294-8, 1975. 
BAHIA FILHO, A.F.C.; FRANÇA, G.E.; PITTA, G.V.E.; MAGNAVACA, R.; MENDES, J.F.; BAHIA, F.G.T.C.; PEREIRA, P. Avaliação de linhagens e populações de milho em condições de elevada acidez. In: REUNIÃO BRASILEIRA DE MILHO E SORGO, 2., Piracicaba, 1976. Anais. Piracicaba, ESALQ, 1978. p.51-8.

BATAGLIA, O.C.; CAMARGO, C.E.O.; OLIVEIRA, O.F. de; NAGAI, V.; RAMOS, V.J. Resposta à calagem de três cultivares de trigo com tolerância diferencial ao alumínio. Revista Brasileira de Ciência do Solo, Campinas, 9:139-47, 1983.

BAUMGARTNER, J.G.; HAAG, H.P.; OLIVEIRA, G.D. de; PERECIN, D. Tolerância de cultivares de tomateiro (Lycopersicon esculentum) ao alumínio e ao manganês. In: HAAG, H.P. \& MINAMI, K., coord. Nutrição mineral de hortaliças. Campinas, Fundação Cargill, 1988. p.387-427.

BEAR, F.E. Chemistry of the soil. 2.ed. New York, Rheinhold, 1964. 515p.

BENNET, R.J.; BREEN, C.M.; FEY, M.V. Aluminium toxicity and induced nutrient disorders involving the up-take and transport of $\mathrm{P}, \mathrm{K}, \mathrm{Ca}, \mathrm{Mg}$ in Zea mays $\mathrm{L}$. In: ANUAL CONGRESS OF THE SOUTH AFRICAN SOCIETY OF CROP PRODUCTION, 15., Pielermaritzburg, 1985. Proceedings. Pielermaritzburg, 1985. p.237-61. 
BINGER, A.H. Effect of humic acid on aluminum and maganese toxicity. Dissertation Abstracts International B, Tifton, 41(4): 1191, 1980.

BOLLARD, E.G. \& BUTTER, G.W. Mineral nutrition of plants. Annual Review of Plant Physiology, Palo Alto, 17:77-105, 1966.

BRAUNER, J.L. \& SARRUGE, J.R. Tolerância de cultivares de trigo (Triticum aestivum L.) ao alumínio e ao manganês. VI. Influência do alumínio e do manganês e do grau de tolerância a cada elemento na absorção do fósforo. Anais da Escola Superior de Agricultura "Luiz de Queiroz", Piracicaba, 37:895-912, 1980.

BROWN, J.C.; AMBLER, J.E.; CHANEY, R.L.; FOY, C.D. Differential responses of plants genotypes to micronutrients. In: MORTVEDT, J.J.; GIORDANO, P.M.; LINDSAY, W.L., ed. Micronutrients in agriculture. Madison, Soil Science Society of America, 1972. p.389-418.

CALBO, A.G. Efeito do alumínio sobre a absorção, o transporte e a distribuição de alguns elementos minerais, em dois cultivares de sorgo (Sorghum bicolor (L.) Moench). Viçosa, 1978. 43p. (Mestrado - Universidade Federal de Viçosa).

CALBO, A.G. \& CAMBRAIA, J. Efeito do alumínio sobre a composição mineral de dois cultivares de sorgo (Sorghum bicolor L. Moench). Revista Ceres, Viçosa, 27:369-78, 1980a. 
CAMARGO, C.E.O.; CAMARGO, O.B.A.; SOUZA, D.M. Diferentes concentrações de alumínio em solução nutritiva na tolerância de cultivares de arroz. Bragantia, Campinas, 42(2):357-68, 1984.

CAMARGO, O.A. \& FURLANI, P.R. Alumínio ao solo: concentração, especiação e efeito no desenvolvimento radicular. In: SIMPÓSIO AVANÇADO DE SOLOS E NUTRIÇÃO DE PlanTAS, 2., Piracicaba, 1989. Anais. Campinas, Fundação Cargill, 1989. p.45-69.

CAMBRAIA, J. Mecanismo de tolerância à toxidez de alumínio em plantas. In: REUNIÃO BRASILEIRA DE FISIOLOGIA VEGETAL, 2., Piracicaba, 1989. Anais. Piracicaba, SBFV, ESALQ, 1989. p.85-92.

CAMERON, R.S.; RITCHIE, G.S.P.; ROBSON, A.D. Relative toxicities of inorganic aluminum complexes to barley. Soil Science Society of America Journal, Madison, 50:1231-6, 1986.

CASTELL, A.J.; BARROS, N.F.; NOVAIS, R.E.; SANT'ANNA, R.; NEVES, J.C.L. Absorção de fósforo como critério de seleção de genótipos de soja quanto à tolerância ao alumínio. Pesquisa Agropecuária Brasileira, Brasília, 20(10):1163-70, out. 1985. 
CERETTA, C.A. Tolerância ao alumínio em cultivares de milho. In: CONGRESSO NACIONAL DE MILHO E SORGO, 16., Chapecó, 1986. Resumos. Chapecó, CNPMS, 1986. p. 100.

CLARK, R.B. Differential magnesium efficiency in maize inlireds. 1. Dry-matter yields and mineral element composition. Soil Science Society of America Proceedings, Madison, 39: 488-91, 1975.

CLARK, R.B. Effects of aluminum on plant growth and mineral elements of Al-tolerant and Al-intolerant corn. Plant and Soil, The Hague, 47(3):653-62, 1977.

CLARK, R.B. \& BROWN, J.C. Differential phosphorus uptake by phosphorus - stressed corn inbreds. Crop Science, Madison, 14:505-8, 1974.

CLARKSON, D.T. The effect of aluminum and some other trivalent metal cations on cell division in the root apices of Allium cepa. Annals of Botany, Oxford, 29:309-15, 1965.

CLARKSON, D.T. Metabolic aspects of aluminum toxicity and some possible mechanisms for resistence. In: RORISON, I.H., ed. Ecological aspects of the mineral nutrition of plants. Oxford, Blackwell Scientific, 1969. p.381-97. 
CLARKSON, D.T. \& SANDERSON, J. Inhibition of the uptake and long distance transport of calcium by aluminium and other polyvalent cations. Journal of Experimental Botany, Oxford, 22:837-51, 1971.

EVANS, C.E. \& KAMPRATH, E.J. Lime response as related to percent Al saturation, solution $\mathrm{Al}$ and organic matter content. Soil Science Society of America Proceedings, Madison, 34:893-6, 1970.

FAGERIA, N.K. Tolerância diferencial de cultivares de arroz ao alumínio em solução nutritiva. Pesquisa Agropecuária Brasileira, Brasília, 17(1):1-9, 1982.

FARINA, M.P.W.; SUMMER, M.E.; PLANK, C.O.; LETZSCH, W.S. Aluminum toxicity in corn at near neutral soil pH levels. Journal of Plant Nutrition, New York, 2(6): 683-97, 1980.

FLEMING, A.L. \& FOY, C.D. Root structure reflects differential aluminium tolerance in wheat varieties. Agronomy Journal, Madison, 75:726-30, 1983.

FONSECA Jr., N.S.; MARIA, J.; SEDIYAMA, T.; PEREIRA, M.G.; YAMADA, M.M.; TRAGNAGO, J.L. Método de deteç̧ão visual da sensibilidade do alumínio em soja. In: SEMINÁRIO NACIONAL DE PESQUISA DE SOJA, 2., Brasília, 1981. Anais. Londrina, EMBRAPA, 1981. 
FOX, R.L. \& KANG, B.T. Influence of phosphorus fertilizer placement and fertilizer rate on maize nutrition. Soil Science,Baltimore, 125: 34-40, 1978.

FOY, C.D. Effects of aluminum on plant growth. In: CARSON, E.W., ed. The plant root and its environment. Charlottesville, Univ. Press of Virginia, 1974. p.601-42.

FOY, C.D. Physiological effects of hydrogen, aluminum, and manganese toxicities in acid soil. In: ADAMS, F., ed. Soil acidity and liming. 2.ed. Madison, Soil Science Society of America, 1984. p.57-97.

FOY, C.D. Plant adaptation to acid, aluminum - toxic soils. Communications in Soil Science and Plant Analysis, New York, 19:959-87, 1988.

FOY, C.D. Soil chemical factors limiting plant root growth. In: HATFIELD, J.L. \& STEWART, B.A., ed. Limitations to plant root growth. New York, SpringerVerlag, 1992. p.97-149.

FOY, C.D. \& BROWN, J.C. Toxic factors in acid soils: I. Characterization of aluminium toxicity in cotton. Soil Science Society of America Proceedings, Madison, 27:403-7, 1963. 
FOY, C.D. \& BROWN, J.C. Toxic factors in acid soils. II Differential aluminum tolerance of plant species. Soil Science Society of America Proceedings, Madison, 28:27-32, 1964.

FOY, C.D.; CHANEY, R.L.; WHITE, M.C. The physiology of metal toxicity in plants. Annual Review of Plant Physiology, Palo Alto, 29:511-66, 1978.

FOY, C.D. \& FLEMING, A.L. The physiology of plant tolerance to excess available aluminum and manganese in acid soils. In: JUNG, G.A., ed. Crop tolerance to suboptimal land conditions, Madison, American Society of Agronomy, 1978. p.301-28.

FOY, C.D. \& FLEMING, A.L. Aluminum tolerance in two wheat genotypes related to nitrate reductase activities. Journal of Plant Nutrition, New York, 5:1313-33, 1982.

FOY, C.D.; FLEMING, A.L.; ARMINGER, W.H. Aluminum tolerance of soybean varieties in relation to calcium nutrition. Agronomy Journal, Madison, 61:505-11, 1969.

FOY, C.D.; FLEMING, A.L.; GERLOFF, G.C. Differential aluminum tolerance in two snapbean varieties. Agronomy Journal, Madison, 64:815-8, 1972. 
FOY, C.D.; GERLOFF, G.C.; GALBELMAN, W.H. Effects of aluminum on the vegetative growth of tomato cultivars in acid soil and nutrient solution. Journal of the American Society for Horticultural Science, Alexandria, 98:427-32, 1973.

FOY, C.D.; FLEMING, A.L.; BURNS, G.R.; ARMINGER, W.H. Characterization of differential aluminum tolerance annong varieties of wheat and barley. Soil Science Society of America Proceedings, Madison, 31:513-21, 1967a.

FOY, C.D.; ARMIGER, W.H.; FLEMING, A.L.; ZAUMEYER, W.I. Differential tolerance of dry bean, snap bean and lima bean varieties to an acid soil high in exchangeable aluminum. Agronomy Journal, Madison, 59:561-3, $1967 \mathrm{~b}$.

FOY, C.D.; CHANEY, R.L.; WHITE, M.C. The physiology of metal toxicity in plants. Annual Review of Plant Physiology, Palo Alto, 29:511-66, 1978.

FRINK, C.R. \& PEECH, M. Hydrolysis and exchange reactions of the aluminum ion in hectorite and montmorillonite suspensions. Soil Science Society of America Proceedings, Madison, 27:527-30, 1963.

FURLANI, A.M.C. \& FURLANI, P.R. Cultivo de plantas de arroz, milho e sorgo em solução nutritiva para estudo da tolerância ao alumínio. In: - Composição e pH de solução mutritiva para estudos fisiológicos e seleção de plantas em condições nutricionais adversas. Campinas, IAC, 1988. p.21-6. (IAC. Boletim Técnico, 121). 
FURLANI, P.R. Toxicidade de alumínio e manganês em plantas. In: RAIJ, B. van; BAtaglia, O.C.; SILVA, N.M. da., coord. Acidez e calagem no Brasil. Campinas, Sociedade Brasileira de Ciência do Solo, 1983. p.79-85.

FURLANI, P.R. Efeitos fisiológicos do alumínio em plantas. In: SIMPÓSIO AVANÇADO DE SOLOS E NUTRIÇÃo DE PlANTAS, 2., Piracicaba, 1989. Anais. Campinas, Fundação Cargill, 1989. p.73-90.

FURLANI, P.R. \& BERTON, R.S. Atividade de cálcio e alumínio e desenvolvimento radicular. In: SEMINÁRIO SOBRE O USO DE GESSO NA AGRICULTURA, 2., Uberaba, 1992: s.1. IBRAFOS, 1992. p.121-38.

FURLANI, P.R. \& CLARK, R.B. Screening sorghum for aluminum tolerance in nutrient solutions. Agronomy Journal, Madison, 73: 587-94, 1981.

FURLANI, P.R. \& HANNA, L.G. Avaliação da tolerância de plantas de arroz e milho ao alumínio em solução nutritiva. Revista Brasileira de Ciência do Solo, Campinas, 8(2):205-8, 1984.

FURLANI, P.R.; LIMA, M.; MIRANDA, L.T. de; MIRANDA, L.E.C. de; SAWAZAKI, E.; MAGNAVACA, R. Avaliação de linhagens, materiais comerciais e duas populações de milho para tolerância ao alumínio. Pesquisa Agropecuária Brasileira, Brasília, 21 (6): 655-60, 1986. 
GALVÃO, J.D. \& SILVA, J.C. Herança da tolerância ao alumínio na variedade de milho Piranão. Revista Ceres, Viçosa, 25: 71-8, 1978.

GARCIA JÚNIOR, O. \& SILVA, W.J. Análises genéticas da tolerância ao alumínio em milho. Ciência e Cultura, São Paulo, 31: 585, 1979.

GOMES, F.P. Curso de estatística experimental. Piracicaba, Livraria Nobel, 1981. 430p.

GONÇALVEZ, P.A.; COSTA, C.; CAMPOS, L. Solos tropicais sob pastagens. São Paulo, Ícone, 1992. 76p.

GOODLAND, R. Oligotrofismo e aluminismo no cerrado. In: SIMPÓSIO SOBRE O CERRADO, 3., 1971. São Paulo, 1971, p.44-60.

GRIMME, $\mathrm{H}$. The effect of $\mathrm{Al}$ on $\mathrm{Mg}$ uptake and yield of oasts. In: INTERNATIONAL PLANT NUTRITION COLLOQUIUM, 9., Conventry, 1982. Proceedings. Conventry, Warwick University, p. 198-203.

GRIMME, H. Aluminium induced magnesium deficiency in oats. Zeitscrift fuer Pflan zenernaehrung Bodenkunde, Weinheim, 146: 666-76, 1983. 
GRIMME, J.P. \& HODGSON, J.G. An investigation of the ecological significance of lime-chlorosis by means of large-scale comparative experiments. In: RORISON, I.H., ed. Ecological aspects of the mineral nutrition of plants. Oxford, Blackwell Scientific, 1969. p.67-99.

HALLSWORTH, E.G.; GREENWOOD, E.A.N.; AUDEN, J. Some nutrient interactions affecting the growth of pasture legumes in acid soils. Journal of the Science of Food and Agriculture, London, 8: 560-5, 1957.

HARGROVE, W.L. \& THOMAS, G.W. Extraction of aluminum from aluminum-organic matter complexes. Soil Science Society of America Journal, Madison, 45:151-3, 1981.

HARTWELL, B.L. \& PEMBER, F.R. The presence of aluminum as a reason for the difference in the effect of so - called acid soil on barley - and rye. Soil Science, Baltimore, 6: 259-79, 1918.

HECHT-BUCHHOLZ, C. \& SCHUSTER, J. Responses of Al tolerant Dayton and Al sensitive Kearney barley cultivars to calcium and magnesium during $\mathrm{Al}$ stress. In: SYMPOSIUM ON GENETIC ASPECTS OF PLANT MINERAL NUTRITION, 2., Madison, 1985, Genetic aspects of plant nutrition; proceedings. Dordrecht, Martinus Nijhoff, 1987. p. 223-37. 
HETHERINGTON, S.J.; ASHER, C.J; BLAMEY, F.P.C. Comparative tolerance of sugarcane, navybean, soybean and maize to aluminum toxicity. Australian Journal of Agricultural Research, East Melbourne, 39(2):171-6, 1988.

HOWELLER, R.H. \& CADAVID, L.F. Screening rice cultivars for tolerance to Al toxicity in nutrient solutions as compared with a field screening method. Agronomy Journal, Madison, 68: 551-5, 1976.

HUCK, M.G. Environment of sucrose utilization for cell wall formation in the root of aluminum - demaged cotton seedings. Plant and Cell Physiology, Tokyo, 13:7-14, 1972.

HUE, N.V.; CRADDOCK, G.R.; ADAMS, F. Effect of organic acids on aluminum toxicity in subsoils. Soil Science Society of America Journal, Madison, 50:28-34, 1986.

HUTCHINSON, G.E. Aluminum in soils, plants and snimals. Soil Science, Baltimore, 60:29-40, 1945.

JACKSON, M.L. Aluminum bonding in soils: A unifying principle of soil science. Soil Science Society of America Proceedings, Madison, 27:1-9, 1963. 
JACKSON, W.A. Physiological effects of soil acidity. In: PEARSON, R.W. \& ADAMS, F., ed. Soil acidity and liming. Madison, American Society of Agronomy, 1967. p.43-124. 1967. (Agronomy, 12).

JONES, J.P. \& FOX, R.L. Phosphorus nutrition of plants influenced by manganese and aluminum uptake from an Oxisol. Soil Science, Baltimore, 126(4):230-6, 1978.

JONES, L.H. Aluminum uptake and toxicity in plants. Plant and Soil, The Hague, 13:292-310. 1961.

JUNGK, A. \& BARBER, S.A. Phosphate uptake rate of corn roots as related to the proportion of the roots exposed to phosphate. Agronomy Journal, Madison, 66: $554-7,1974$.

KAMPRATH, E.J. Residual effect of large applications of phosphorus on high phosphorus fixing soils. Agronomy Journal, Madison, 59: 25-7, 1967.

KAMPRATH, E.J. Exchangeable aluminum as a criterion for liming leached mineral soils. Soil Science Society of America Proceedings, Madison, 34: 252-4, 1970.

KERRIDGE, P.C. Aluminum toxicity in wheat. (Triticum aestivum Vill., Host). Corvallis, 1969, 170p. (PhD - University of Oregon). 
KINRAIDE, T.B. Identity of the rhizotoxic aluminum especies. In: WRIGHT, R.J. Plant - soil interaction at low pH. Dordrecht, Kluwer Academic Publishers, 1991. p.717-28.

KINDRAIDE, T.B. \& PARKER, D.R. Cation amelioration of aluminum toxicity in wheat. Plant Physiology, Bethesda, 83:546-51, 1987.

KLIMASHEVSKY, E.L.; MARKOVA, Y.A.; SEREGINA, M.L.; GRODZINSKII, D.M.; KOZANENKO, T.D. Specifics of the physiological activity of pea plant in connection with une geral resistence of different varieties to mobile aluminum. Soviet Plant Physiology, New York, 17: 372-8, 1970.

KRIZEK, D.T. \& FOY, C.D. Elemental content of two barley cultivars in relation to water stress and aluminium toxicity. In: INTERNATIONAL PLANT NUTRITION COLlOQUIUM, 9., Coventry, 1982. Abstracts. Coventry, Warwick University, 1982. p. 198-203.

LANCE, J.C. \& PEARSON, R.W. Effect of low concentrations of aluminum on growth and water and nutrient uptake by cotton roots. Soil Science Society of America Proceedings, Madison, 33:95-8, 1969.

LARKIN, P.J. Calmodulin level are not responsible for aluminum tolerance in Wheat. Australian Journal of Plant Physiology, East Melbourne, 14:377-85, 1987. 
LEE, C.R. Influence of aluminum on plant growth and mineral nutrition of potates. Agronomy Journal, Madison, 63:604-8, 1971.

LEFEVER, H.N. Genetic differences in plant responses to soil nutrients stress. Journal of Plant Nutrition, New York, 4:89-109, 1981.

LIEBIG Jr., G.F.; SELOW, A.P.; van CHAPMAN, H.D. Effects of aluminum on copper toxicity, as revealed by solution - culture and spectrographic studies of citrus. Soil Science, Baltimore, 53: 341-51, 1942.

LONG, F.L. \& FOY, C.D. Plant varieties as indicator of aluminum toxicity in the $A_{2}$ horizon of Norfolk soil. Agronomy Journal, Madison, 62: 679-81, 1970.

LOPES, A.S. Solos sob cerrado: características, propriedades e manejo. Piracicaba, Instituto Brasileiro de Potássio e Fosfato, 1983. 157p.

LOPES, M.A.; MAGNAVACA, R.; BAHIA FILHO, A.F.C.; GAMA, E.E.G.E. Avaliação de populações de milho e seus cruzamentos para tolerância à toxidez de alumínio em solução nutritiva. Pesquisa Agropecuária Brasileira, Brasília, 22(3):257-63, 1987

MAGNAVACA, $R$. Genetic variability and the inheritance of aluminum tolerance in maize (Zea mays L.) Lincoln, 1982. 135p. (PhD - University of Nebraska). 
MALAVOLTA, R.; SARRUGE, J.R.; BITTENCOURT, V.C. Toxidez de alumínio e manganês. In: SIMPÓSIO SOBRE O CERRADO: bases para a utilização agropecuária, Brasília, 1977. São Paulo, EDUSP, 1977. p.275-302.

MALAVOLTA, E.; VITTI, G.C.; OLIVEIRA, S.A. de. Avaliação do estado nutricional das plantas: princípios e aplicações. Piracicaba, Associação Brasileira para Pesquisa da Potassa e do Fosfato, 1989. 201p.

MALAVOLTA, E.; REICHARDT, K.; BITTENCOURT, V.C.; STEWART, J.B.; SARRUGE, J.R. Elementos não essenciais. In: . Manual de química agrícola; nutrição de planta e fertilidade do solo. São Paulo, Agronômica Ceres, 1976. cap.13, p.453-511.

MALETT, J.B.; CLEMENCE, B.S.C.; FARINA, M.P.W.; BEGHIN, S.M. The determination of optimum depth of lime incorporation in soils with subsoil aluminum toxicity problems. In: ANNUAL CONGRESS OF THE SOUTH AFRICAN SOCIETY OF CROP PRODUCTION, 15., Pietermaritzburg, 1985. Proceedings. Pietermaritzburg, 1985. p.136-44.

MARQUEZINI, M.V.; CELlA, N.; SILVA, E.C.; SERRA, D.B.; LIMA, C. Photoacustic assessment of the in vivo genotypical response of corn to toxic aluminum. The Analyst, London, 115 (3): 341-3, 1990. 
MATSUMOTO, H. \& YAMAYA, T. Inhibition of potassium uptake and regulation of membrane - associated $\mathrm{Mg}_{2+}$ - ATPase activity of pea roots by aluminum. Soil Science and Plant Nutrition, Tokyo, 32: 179-88, 1986.

MATSUMOTO, H.; HIRSAWA, F.; MORIMURA, S.; TAKAHASHI,E. Localization of aluminum in tea leaves. Plant and Cell Physiology, Kyoto, 17: 890-5, 1976.

McLEAN, F.T. \& GILBERT, B.E. The relative aluminum tolerance of crop plants. Soil Science, Baltimore, 24: 163-77, 1927.

MENDES, P.; FARINA, M.P.W.; CHANNON, P. Assessment of aluminum tolerance in maize using a rapid screening procedure. South Agrican Journal of Plant and Spil, Pretoria, 1:83-6, 1984.

MINELLA, E. Aluminum tolerance in barley: inheritance, chromosome location, genetic relationship of sources of diverses origins and breding implications. Ithaca, 1989.70p. (PhD - Cornell University).

MOORE, D.P. Physiological effects of pH on roots. In: CARSON, E.W., ed. The plant root and its enviroment. Charlottesville, University Press of Virginia, 1974. p.135-41. 
MOORE, D.P.; KRONSTAD, W.E.; METZGER, R.J. Screening wheat for aluminum tolerance. In: WORKSHOP ON PLANT ADAPTATION TO MINERAL STRESS PROBLEM SOILS, Beltsville, 1976. Plant adaptation to mineral stress in problem soils; proceedings, edited by M.J. Wright and S.A. Ferrari. Ithaca, Cornell University, 1976. p.287-95.

MOSQUIM, P.R. Influência do alumínio sobre o crescimento e o metabolismo em plantas de Stylosanthes humilis. H.B.R. Viçosa, 1978. (Mestrado - Universidade Federal de Viçosa).

MUNNS, D.N. Soil acidity and growth of a legume. I. Reactions of aluminum and phosphate in solution and effects of aluminum, phosphate, calcium and $\mathrm{pH}$ on Medicago sativa L. and Trifolium subteraneum L. in solution culture. Australian Journal of Agricultural Research, East Melbourne, 16: 743-5, 1965.

OHKI, K. Mn and B effects on micronutrients and $\mathrm{P}$ in cotton. Agronomy Journal, Madison, 67:204-7, 1975.

OLIVEIRA, L.E.M. Crescimento e comportamento nutricional de cultivares de mandioca (Manihot esculenta Crantz) submetidos a níveis de alumínio. Viçosa, 1979.39p. (Mestrado - Universidade Federal de Viçosa). 
OLMOS, I.L.J. \& CAMARGO, M.N. Ocorrência de alumínio tóxicos nos solos do Brasil, sua caracterização a distribuição. Ciência e Cultura, São Paulo, 28: 171-80, 1976.

PAVAN, M.A. \& BIGHAM, F.T. Toxicity of aluminum to coffe seedlings grown in nutrient solution. Soil Science Society of America Journal, Madison, 46:993-7, 1982.

PAVAN, M.A.; BINGHAM, F.T.; PERYEA, F.J. Influence of calcium and magnesium salts on acid soil chemistry and calcium nutrition of apple. Soil Science Society of America Journal, Madison, 51:1526-30, 1987.

PIMENTA, J.A.; CAMBRAIA, J.; SANT'ANA, R; ESTEVÃO, M.M. Efeito do alumínio sobre algumas enzimas ligadas a assimilação do nitrogênio no sorgo. In: REUNIÃO BRASILEIRA DE FISIOLOGIA VEGETAL, 1., Londrina, 1987. Resumos. Londrina, SBFV, 1987. p.22.

POLLE, E.; KONZAK, C.F.; KITTRICK, J.A. Visual delection of aluminum tolerance levels in wheat by hematoxylin stain of seedlings roots. Crop Science, Madison, 18:823-7, 1978

PRATT, P.F. Aluminum. In: CHAPMAN, H.D., ed. Diagnostic criteria for plants and soils. Berkeley, University of California, Division of Agricultural Sciences, 1966. 
PRIMAVESI, A. O manejo ecológico do solo. 4.ed. São Paulo, Nobel, 1982. 541p.

PRIOLI, S.M.A.P.; SILVA, J.C.; GALVÃO, J.D.; MONNERAT, P.H.; PRIOLI, A.J. Seleção da tolerância a toxidez de alumínio em milho (Zea mays L.). Revista Ceres, Viçosa, 3(183): 441-51, 1985.

RAGLAND, J.L. \& COLEMAN, N.T. The hydrolysis of aluminum salts in clay and soil systems. Soil Science Society of America Proceedings, Madison, 24:457-60, 1960.

RAIJ, B. van. Gesso agrícola na melhoria do ambiente radicular no subsolo. São Paulo, Associação Nacional para Difusão de Adubos e Corretivos Agrícolas, 1988. 88p.

RANDALL, P.J. \& VOSE, P.B. Effect of aluminum on uptake and translocation of phosphorus 32 by perennial ryegrass. Plant Physiology, Bethesda, 38:403-9, 1963.

RASMUSSEN, H.P. The mode of entry and distribution of aluminum in Zea mays: Eletronmicroprobes-ray analysis. Planta, Berlin, 81:28-37, 1968.

REID, D.A. Genetic potencials for solving problems of soil mineral stress: aluminum and manganese toxicities in the cereal grains. In: REIGHT, M.J. Plant adaptation to mineral stress in problems soils. Ithaca, Cornell University, 1976. p.55-64. 
RHUE, R.D. Differential aluminum tolerance in crop plants. In: MUSSEL, H. \& STAPLES, R.C. Stress physiology in crop plants. New York, John Wiley, 1977. p.61-80.

RHUE, R.D. \& GROGAN, C.O. Screening corn for Al tolerance using different Ca and Mg concentration. Agronomy Journal, Madison, 69(5):755-60, 1977.

RHUE, R.D.; GROGAN, C.O.; STOCKMEYER, E.W. \& EVERETT, H.L. Genetic control of aluminum tolerance in corn. Crop Science, Madison, 18:1063-7, 1978.

RIOS, M.A. \& PEARSON, R.W. The effect of some chemical environmental factors on cotton root behavior. Soil Science Society of America Proceedings, Madison, 28:232-5, 1964 .

RITCHEY, K.D.; SILVA, J.E.; SOUZA, D.M.G. Relação entre teor de cálcio no solo e desenvolvimento de raízes avaliado por um método biológico. Revista Brasileira de Ciência do Solo, Campinas, 7:269-75, 1983.

RORISON, I.H. The effect of aluminum on legume nutrition. In: EASTER SCHOOL IN AGRICULTURAL SCIENCES, 5., London, 1958. Nutrition of legumes; proceedings. London, Butterworsths Scientific, 1958. cap.3, p.43-58. 
RORISON, I.H. The effect of aluminum on uptake and incorporation of phosphate by roots. New Phytologist, London, 64:23-7, 1965.

ROY, K.A.; SHARMA, A.; TALUKDER, G. Some aspects of aluminum toxicity in plants. The Botanical Review, Bronse, 54(1):145-78, 1988.

SANTANA, M.B.M.; ROSAND, P.C.; MIRANDA, E.R. Toxidez do aluminio em plântulas de cacau. Revista Theobroma, Itabuna, 3(4):11-21, out./dez. 1973.

SARRUGE, J.R. Soluções nutritivas. Summa Phytopathologica, Piracicaba, 1:231-3, 1975.

SARRUGE, J.R. \& HAAG, H.P. Análises químicas em plantas. Piracicaba, ESALQ, 1974. 55p.

SETIJONO, S. \& SOEPARDI, G. Liming acid mineral soils in Indonesia as a precondition to increase N-efficiency. In: KANG, B.T. \& HEIDE, J. van der. Nitrogen management in farming systems in humid and subhumid tropics. Haren, Institute for Soil Fertility, 1985. p.185-98.

SIEGEL, N. \& HAUG, A. Calmodulin - dependent formation of membrane potential in barley root plasma membrana vesicles: a biochemical model of aluminum toxicity in plants. Physiologia Plantarum, Copenhagen, 59:285-91, 1983. 
SILVA, J.B.C. Seleção de genótipos de sorgo (Sorghum bicolor (L.) Moench) e de soja (Glycine max (L.) Merril) tolerantes a toxidez de alumínio. Viçosa, 1983. 55p. (Mestrado - Universidade Federal de Viçosa).

STRYKER, R.B.; GILLIAN, J.W.; JACKSON, W.A. Nonuniform phosphorus distribution in the root zone of corn; growth and phosphorus uptake. Proceedings of the Soil Science Society of America, Madison, 38:334-40, 1974.

SUHA YDA, C.G. Aluminum toxicity in plants: a potential role for organic acids in the prevention of aluminum-induced cellular damage. Dissertation Abstracts International, B (Sciences and Engineering), Ann Arbor, 47(7):2736B, 1987.

SWHAYDA, C.G. \& HAUG, A. Organic acids reduce aluminum toxicity in maize root membranes. Physiologia Plantarum, Copenhagen, 68:189-95, 1986.

TAN, K.H. \& BINGER, A. Effect of humic acid on aluminum toxicity in corn plants. Soil Science, Baltimore, 141(1):20-5, 1986.

TAYLOR, G.J. The physiology of aluminum tolerance in higher plants. Communications in Soil Science and Plant Analysis, New York, 19(7/12):1179-94, 1988a.

TAYLOR, G.J. The physiology of aluminum phytotoxicity. In: SIGEL, H. \& SIGEL, A., ed. Metal ions in biological systems. New York, Marcel Dekker, 1988b. p.123-63. 
THOMAS, S.G.W. \& HARGROVE, W.L. The chemistry of soil acidity. In: PEARSion, R.W. Soil acidity and liming. Madison, Soil Science Society of America, 1984. p.356.

TRENEL, M. \& ALTEN, F. The physiological importance of mineral soil acidity. The toxic action of aluminum. Angewandte Chemie, Weinheim, 47:813-20, 1934.

VOSE, P.B. Screening techniques for plant nutrient efficiency: phylosophy and methods. In: SYMPOSIUM ON GENETIC ASPECTS OF PLANT MINERAL NUTRITION, 2., Madison, 1985. Genetic aspects of plant mineral nutrition; proceedings. Dordrecht, Martinus Nighoff, 1987. p.283-9.

WAGATSUMA, T. Characterization of absorption sites for aluminum in the roots. Soil Science and Plant Nutrition, Tokyo, 29(4):499-515, 1983a.

WAGATSUMA, T. \& AKIBA, R. Low surface negativity of root protoplasts from aluminum - tolerant plant species. Soil Science and Plant Nutrition, Tokyo, 35(3):44-52, 1989.

WAGATSUMA, T. \& EZOE, Y. Effect of pH on ionic species of aluminum in medium and on aluminum toxicity under solution culture. Soil Science and Plant Nutrition, Tokyo, 31(4):547-61, 1985. 
WAGATSUMA, T. \& KANEKO, M. High toxicity of hidroxy - aluminum polymer ions to plant roots. Soil Science and Plant Nutrition, Tokyo, 33(1):57-67, 1987.

WAGATSUMA, T.; KANEKO, M.; HAYASAKA, Y. Destruction process of plant root cells by aluminum. Soil Science and Plant Nutrition, Tokyo, 33(2):161-75, 1987.

WAGATSUMA, T.; KAWASHIMA, T.; TAWARAYA, K. Comparative stainability of plants root cells with basic dye (methylene blue) in association with aluminum tolerance. Communications in Soil Science and Plants Analysis, New York, 19(7/12):1207-15, 1988.

WALLIHAN, E.F. The influence of aluminum on the phosphorus nutrition of plants. American Journal of Botany, Baltimore, 35:106-12, 1948.

WRIGHT, K.E. The internal precipitation of phosphorus in relation to aluminum toxicity. Plant Physiology, Bethesda, 18:708-12, 1943.

WRIGHT, K.E. \& DONAHUE, B.A. Aluminium toxicity studies with radioactive phosphorus. Plant Physiology, Bethesda, 28:674-80, 1953. 